The 코. AH. Atill Titurary

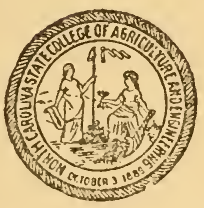

Aortly Caralinit State Collegye

QK971 S5C3 


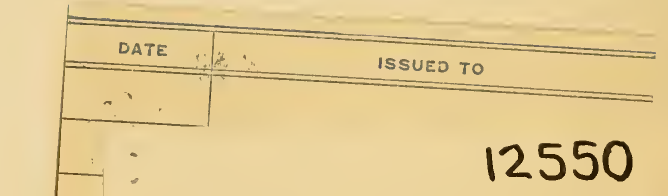

This BOOK may be kept out TWO WEEKS ONLY, and is subject to a fine of FIVE CENTS a day thereafter. It is due on the day indicated below:

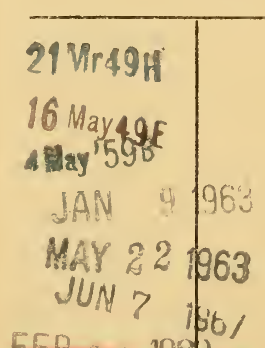




. 


\title{
PLANT HABITS AND HABITATS IN THE ARID PORTIONS OF SOUTH AUSTRALIA
}

\author{
BY \\ WILLIAM AUSTIN CANNON
}

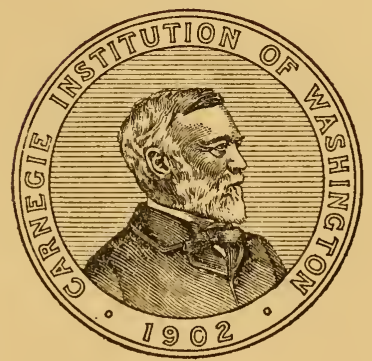

Published by the Carnegie Institution of Washington WASHINGTON, 1921 
CARNEGIE INSTITUTION OF WASHINGTON

Publication No. 308

PRESS OF GIBSON BROTHERS, INC.

WASHINGTON, D. C. 


\section{CONTENTS.}

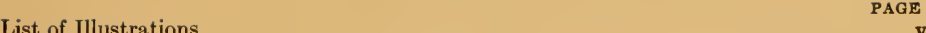

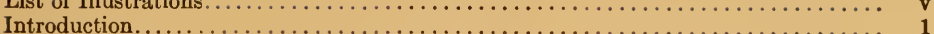

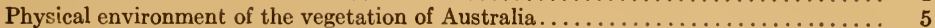

General physiographical conditions...................... 5

Features of the climate of Australia........................... 8

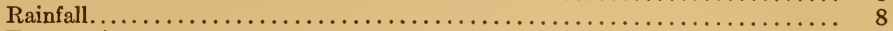

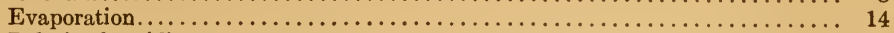

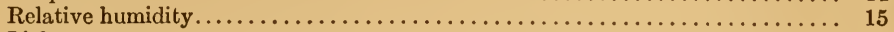

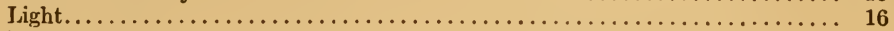

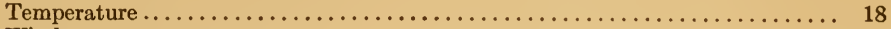

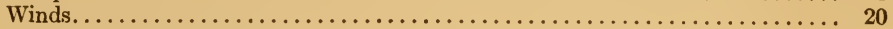

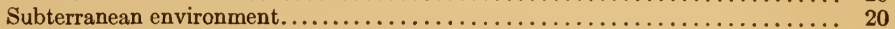

Temperature, moisture, and aeration conditions of the soil............ 23

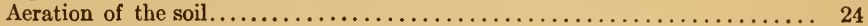

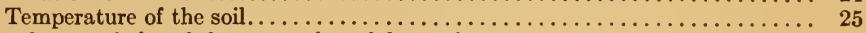

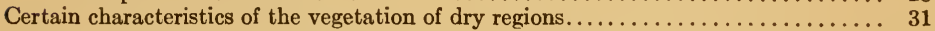

Physical environment of the vegetation of South Australia................ 35

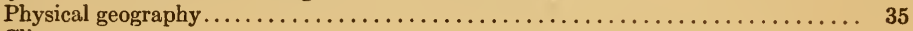

Climate.......................................... 42

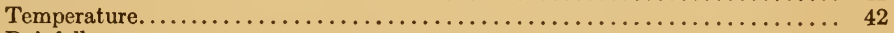

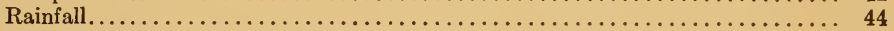

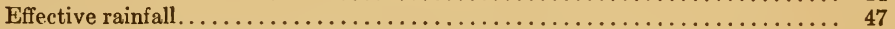

Vegetation and plant habitats in vicinity of Oodnadatta................ 50

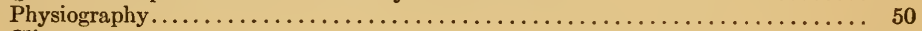

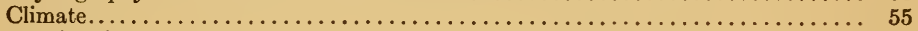

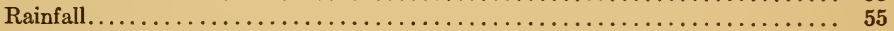

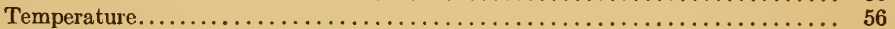

General features of the flora of South Australia ................... 57

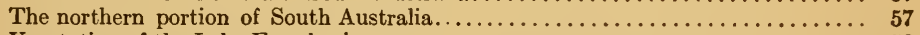

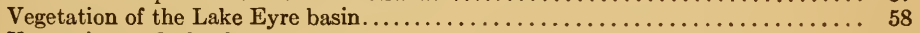

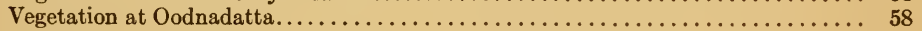

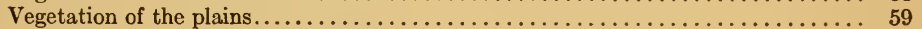

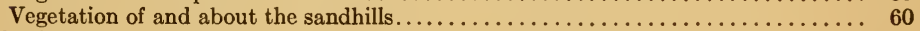

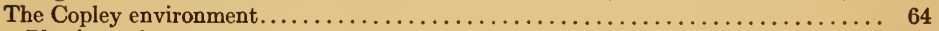

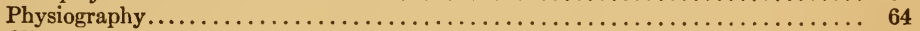

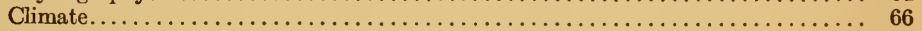

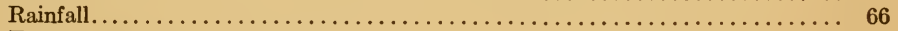

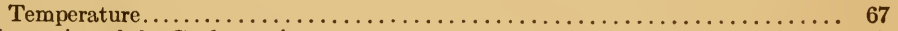

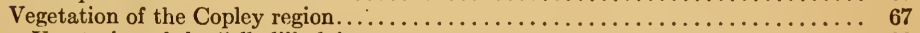

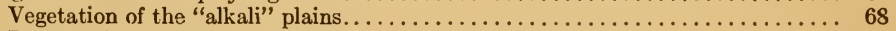

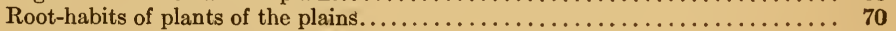

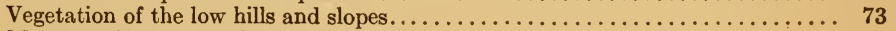

Mono-specific communities.............................. 74

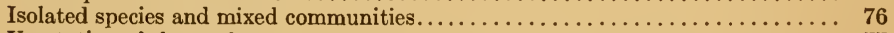

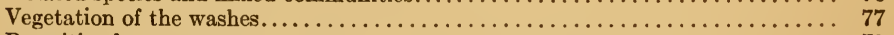

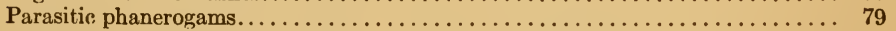

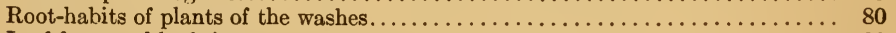

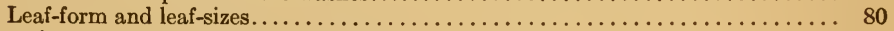

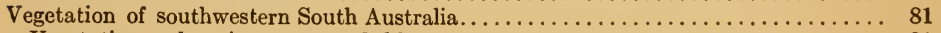

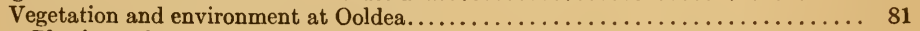

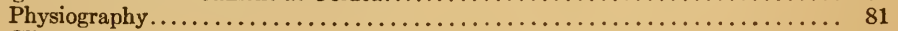

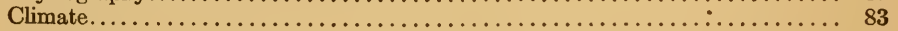

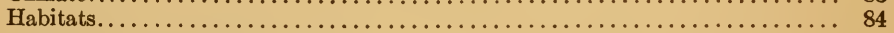

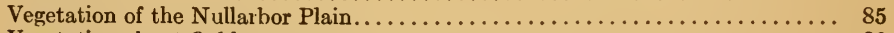

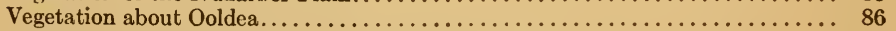

Transition from the sandhills to the Nullarbor Plain ................. 89

Leaf-form and leaf-size..................................... 89 
Vegetation of southwestern South Australia-Continued. PAGE.

Vegetation and environment at Tarcoola.......................... 89

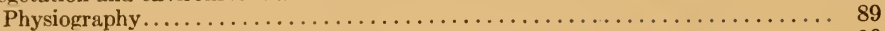

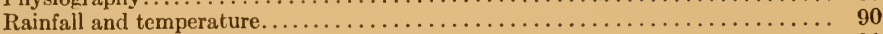

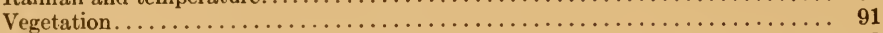

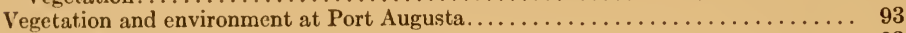

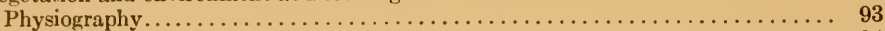

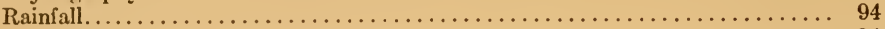

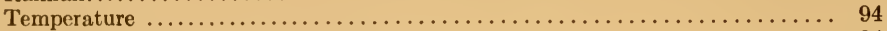

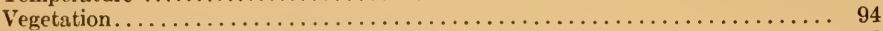

Sizes and forms of leaves and phyllodia........................ 96

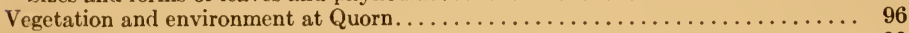

Climate.......................................... 99

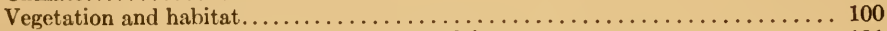

Vegetation of the valleys and of Willochra Plain..................... 101

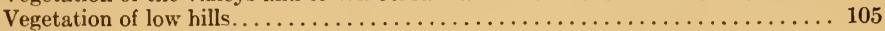

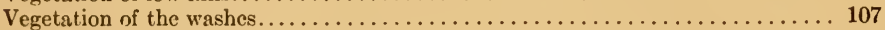

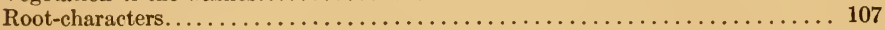

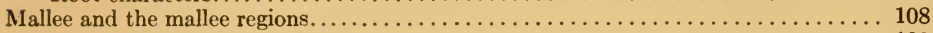

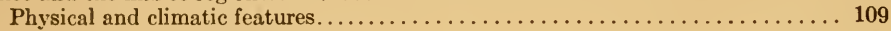

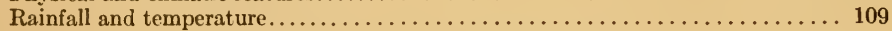

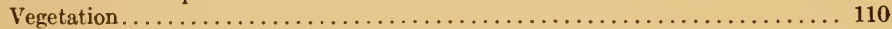

Morphological aspects of the xerophytic flora of South Australia............. 111

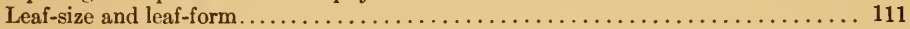

Features of the roots of South Australian plants........................ 114

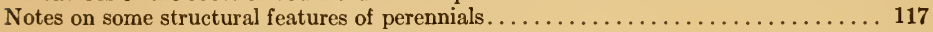

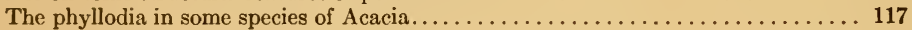

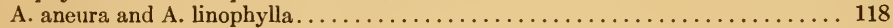

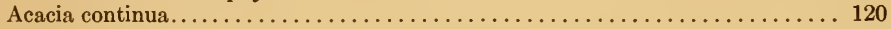

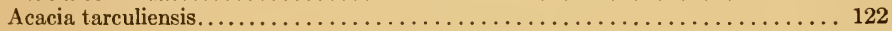

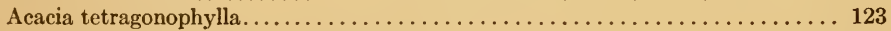

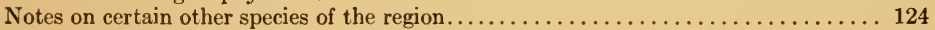

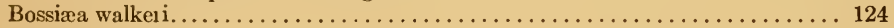

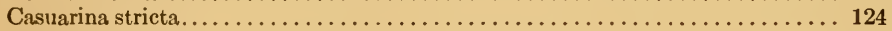

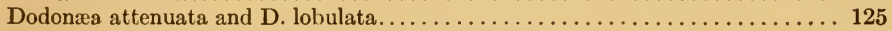

Some morphological features of the genus Eremophila................ 126

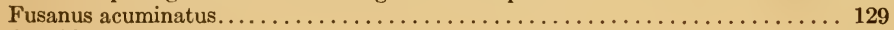

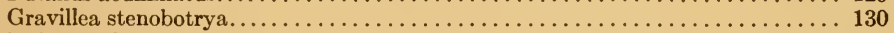

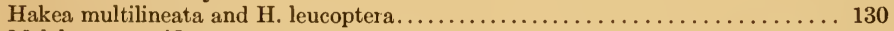

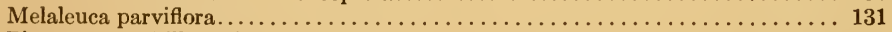

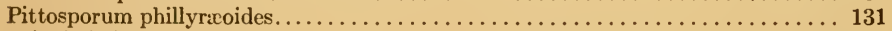

Triodia irritans . . . . . . . . . . . . . . . . . . . . . . . . . . . 132

Certain reactions and adjustments of the plants of the more arid portions of South

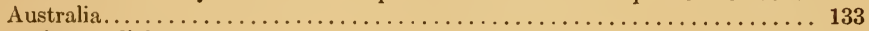

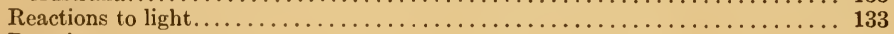

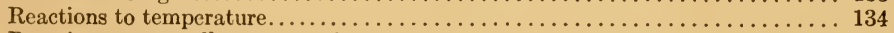

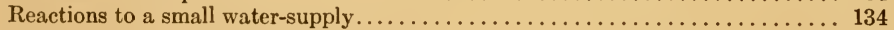

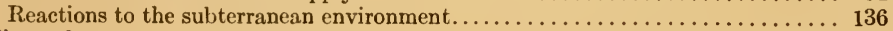

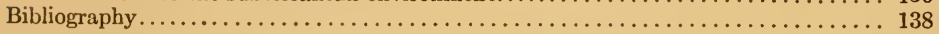




\section{ILLUSTRATIONS.}

\section{PLATES.}

1, A. View looking north from O'Halloran's Mount, Oodnadatta, showing lower plain with upper plain at the extreme right in background.

B. Lower plain near Oodnadatta, showing "gibbers" on the surface and typical depression with species of Eremophila.

2, A. Eremophila freelingii in a shallow wash on the slope of upper plain near Oodnadatta.

B. Eremophila freelingii in a shallow wash on the edge of upper plain west of Neales River, Oodnadatta.

3, A. Acacia cambadgei in a shallow wash on the slope connecting upper and lower plains west of Neales River, Oodnadatta.

B. Shoot-tips with leaves, Eremophila freelingii, from upper plain west of Neales River, Oodnadatta.

c. Shoot-tips with leaves, Eremophila latrobei, from a wash connecting upper and lower plains west of Neales River, Oodnadatta.

4, A. Acacia tetragonophylla, near west base of sandhills east of Oodnadatta.

B. Acacia linophylla on sandhills east of Oodnadatta.

c. Short channel, Neales River, with Eucalyptus rostrata and Acacia stenophylla, small shrubs, on the banks, Oodnadatta.

5, A. Phyllodia of Acacia linophylla from sandhills near Oodnadatta.

B. Eremophila neglecta near base of sandhills east of Oodnadatta.

c. Neales River bottoms from the lower plain, Oodnadatta.

6, A. Shoot-tips and phyllodia of Acacia tetragonophylla, left, and A. cambadgei, right, from Neales River, Oodnadatta.

B. Leaves and phyllodia of Acacia stenophylla from Neales River, Oodnadatta.

7, A. Prominent development of horizontal roots in Acacia cambadgei, Neales River, Oodnadatta.

B. Vegetative reproduction in Acacia stenophylla from floodplain, Neales River, Oodnadatta.

c. Kochia sedifolia on low slope above Copley Plain on Yudnamutana road, Copley.

8, A. Zygophyllum fruticosum at edge of Copley Plain by Table Mountain. The trees in the background are Casuarina lepidophloia, Copley.

B. Nitraria schoberi hillock colonies on Copley Plain. Table Mountain is in the background at left, Copley.

c. Detail of edge of colony of Nitraria schoberi, showing horizontal prostrate branches by which the hillock colony is extended, Copley.

9, A. Shoot-tip of Eremophila freelingii from low hills on Mount Serles road, Copley.

B. Eremophila oppositifolia, showing leaves and flowers, from rounded low hills on Mount Serles road, Copley.

c. Pholidia scoparia, "broom," from low hills on Mount Serles road east of Copley.

19, A. Cassia sturtii, constituting a mono-specific community on Mount Serles road, Copley.

B. Mono-specific community of Eremophila freelingii, in low hills along Mount Serles road, Copley.

c. Mono-specific community of Pholidia scoparia in low hills on Mount Serles road, Copley.

11, A. Hakea leucoptera on southern slope of Table Mountain, Copley.

B. Casuarina lepidophloia, or "oak," at south base of Table Mountain, Copley.

c. Community of Zygophyllum fruticosum near Mount of Light, Copley.

12, A. Petalostylis labicheoides from south base of Table Mountain, Copley.

B. Casuarina lepidophloia, Copley.

c. Petalostylis labicheoides at south base of Table Mountain, Copley.

D. Shoot habit of Hakea leucoptera, with fruit, from Table Mountain, Copley .

13, A. Melaleuca glomerata, the "white" tea-tree, in a small branch of Leigh's Creek, Mount Serles road, Copley.

B. Melaleuca parviflora, the "black" tea-tree, near Myrtle Springs road, Copley.

c. Eucalyptus rostrata, the red gum, on Leigh's Creek, Copley.

14, A. Eremophila alternifolia at side of small wash near Mount of Light, Copley.

B. Eremophila longifolia on edge of Copley Plain near Leigh's Creek, Copley. 
15, A. Shoot-tip showing leaves and fruits of Melaleuca parviflora, or "black" tea-tree, from Myrtle Springs road, Copley.

в. Tip of shoot of Eremophila alternifolia with flowers and leaves, Copley.

c. Leafy shoot of Acacia varians from a wash east of Copley.

D. Melaleuca glomerata, "white" tea-tree, from Leigh's Creek, Copley.

16, A. Eremophila longifolia, Copley.

B. Branch of Acacia tetragonophylla with short spinose phyllodia and inflorescence buds, Copley.

c. Acacia tetragonophylla in low hills on Mount Serles road, east of Copley.

17, A. Leafy shoot-tips with fruit of Fusanus spicatus, the "quandang," and F. acuminatus, the native "peach," Mount Deception Range, Copley.

B. Myoporum platycarpum from low hills in Mount Serles road, Copley.

c. Shoot-tip with leaves and fruit of Loranthus exocarpi and leafy branch of host, Acacia sentis, Copley.

D. Loranthus exocarpi, at right, and Eremophila brownii, host, Copley.

18, A. Loranthus quandang, with oval leaves, and the narrow-leaved form of Acacia aneura, the "mulga," its host. From Mount Searles road, east of Copley.

B. Loranthus linearifolius on Acacia tetragonophylla. The host is shown with characteristic spine-like phyllodia. Copley.

c. Loranthus exocarpi, with leaves and fruit and shoot-tip of its host, Myoporum platycarpum, Copley.

19, A. Acacia aneura, the mulga, at Ooldea.

B. Eucalyptus oleosa by a wash at the eastern base of Mount Deception Range. The prominent stem base and enlarged crown of the taproot, both characteristics of the "mallee," are shown. Copley.

20, A. Detail of branch of Acacia colletioides showing spine-like phyllodia Ooldea.

B. Narrow "leaf" form of Acacia aneura, the mulga, at Ooldea. Young fruits are shown on one of the branches.

c. Broad "leaf" form of Acacia aneura, the mulga, at Ooldea.

21, A. Eucalyptus pyriformis at Ooldea. Various species of Acacia and the mallee, Eucalyptus incrassata var. dumosa, make up the surrounding woody vegetation. The floor is bare.

B. Eucalyptus leucoxylon var. macrocarpa, middle ground, and E. incrassata var. dumosa, on the hillside beyond, near Ooldea.

22, A. Fruits of Eucalyptus pyriformis from Ooldea. The fruits are about $5 \mathrm{~cm}$. in diameter.

B. Leptospermum lavigatum var. minus, in flower, from the Ooldea Soak.

c. The shrubby Eucalyptus leucoxylon var. macrocarpa in flower, from Station 408 near Ooldea.

23, A. Pholidia santalina from mallee community of low ridge west of Quorn.

B. Callistemon teretifolius, from ridge on Mount Arden road, Quorn.

c. Aphyllous Acacia continua from low hills on the Pichi Richi road, west of Quorn.

D. Tip of branch of Acacia calamifolia, in fruit, showing the linear phyllodia. From open Casuarina forest on the Melrose road, east of Quorn.

24, A. Gravillea stenobotrya shoot showing leaves and fruits, from Station 408, near Ooldea.

B. Leaf habit of Eremophila rotundifolia, Tarcoola.

c. Tips of a branch of Acacia rigens, with phyllodia, Tarcoola.

D. A fruiting branch of Acacia tarculiensis showing characteristic phyllodia. From type habitat, Tarcoola.

25, A. Acacia rigens, the "myall," with various halophytes, on plain north of Tarcoola.

B. Thicket of mallee, Eucalyptus oleosa, on sloping saltbush plain, foothills of the Flinders, east of Port Augusta, near Saltia.

c. "Beef wood," Gravillea stenobotrya, on the crest of sandhill by Station 408, near Ooldea.

26, A. Forest of Eucalyptus rostrata on Saltia creek, east of Port Augusta.

B. Pine community, Callitris rabusta, at Warren's Gorge, near Quorn.

c. View in mallee scrub, about 2 miles north of Quorn. Eucalyptus odorata and $\boldsymbol{E}$. oleosa in the background. Bunches of Triodia irritans in the foreground. 
27, A. Branches of Acacia sublanata, showing small and rigid phyllodia, Quorn.

B. Eutaxia empetrifolia, showing the small flowers and linear short leaves, Quorn.

c. Branches of Acacia pycnantha, the "golden wattle," showing the character of the large phyllodia, Quorn.

28, A. View about 2 miles west of Quorn, taken from a grassy ridge and looking upon a ridge which is covered with mallee. In the intervening valley are a few specimens of Eucalyplus leucaxylon var. pauperita.

B. Hakea leucaptera on the edge of the mallee scrub, about 2 miles north of Quorn. Small shoots which spring from superficial roots of the larger plants are in the foreground.

c. Western slope of ridge along Mount Arden road, Quorn, with Triadia irritans and Trichinium, dominant grasses. Dead fruiting stalks of Xantharrhoea semiplana shown in the foreground; mallee, Eucalyptus sp., in the background.

29, A. Bassice walkeri on summit of a sandhill by Station 408 , near Ooldea.

B. Hakea multilineata on the crest of a sandhill by Station 408, near Ooldea, with Eucalyptus incrassata var. dumasa, a mallee, in the flats below. Bunches of spinifex, Triodia irritans, are to be seen between the mallee.

c. Branch with withered flower-spike and leaves of Hakea multilineata, from Station 408, near Ooldea.

D. Melaleuca uncinata in fruit, from the sandhills by Station 408 , near Ooldea.

30, A. A community of Acacia pycnantha, the golden wattle, by a streamway on the Mount Brown road, Quorn.

B. A large specimen of Eucalyptus leucaxylan var. pauperita, by a wash on the Mount Arden road, Quorn. A comparison with the automobile will give an idea of its size.

c. Vegetative reproduction in Hakea leucaptera. A young shoot, removed from the soil, is shown taking its origin from a horizontal root. Quorn.

31, A. Exposure of roots of mallee, Eucalyptus sp., by a narrow wash, showing the abundance of superficial roots. Along the Mount Arden road, Quorn.

B. Root exposure of Eucalyptus leucoxylan var. pauperita by erosion of the bank of stream above Warren's Gorge. The roots were washed out for a distance exceeding 16 meters. Quorn.

32, A. Scattered groups of Melaleuca parviflora, in the mallee scrub near Blanchtown.

B. Flood plain of the Murray River showing open forest of Eucalyptus rostrata partly submerged, Blanchtown.

c. View in mallee, Eucalyptus sp., scrub on Murray flats near Blanchtown.

\section{FIGURES.}

1. Physical divisions of Australia, after Gregory, 1916, to which has been added the 10 -inch isohyet. The shaded areas have an altitude of 1,000 feet or more above the sea.

2. Mean annual rainfall map of Australia, adapted from Hunt.

3A. Duration of wet seasons, after Taylor, 1916. "The periods shown on the map include those months in which the average rainfall exceeds the geometric mean of the monthly rainfalls."

3в. Wettest months of the year, after Hunt's meteorological map of Australia, 1916.

4A. Mean rainfall of Australia for January, after Hunt.

4B. Mean rainfall of Australia for April, after Hunt.

5A. Mean rainfall of Australia for July, after Hunt.

5в. Mean rainfall of Australia for October, after Hunt.

6. Graphs, after Hunt, showing average monthly rainfall and mean monthly evaporation, in inches, for various places in Australia.

7A. Mean humditiy of Australia for January, after Taylor, 1918.

7в. Mean humidity of Australia for July, after Taylor, 1918.

8A. Mean annual evaporation in Australia, after Hunt.

8B. Average yearly temperature of Australia, after Hunt.

9A. Mean temperature of Australia for January, after Hunt.

9в. Mean temperature of Australia for July, after Hunt. 
10. Chief physical divisions and geographical plan of South Australia, after Howchin and Gregory, with the 5-, 10-, and 15-inch isohyets.

11. Graphs showing the annual (total) and "non-effective" rainfall for 1901-1906 at Oodnadatta (a), Copley (b), and Quorn (c), South Australia, based on records supplied by the Adelaide office of the Commonwealth Bureau of Meteorology.

12. Acacia linophylla, transverse section of phyllode, semi-diagrammatic, $\times 72$. The large proportion of mechanical tissue is indicated $(s c)$, and the protected position of the chlorenchyma $(\mathrm{ch})$. The relatively heavy covering of hairs is indicated by the stippling.

13. Same. Detail of margin of phyllode to show the nature of the sclerenchyma and epidermal cells and the presence of glandular trichomes, $\times 700$.

14. Same. Detail of inner portion of chlorenchyma showing its relation to the fibrovascular bundle at the left, $\times 700$.

15. Acacia continua, transverse section of chlorophyll-bearing stem, $\times 52.5$.

16. Acacia tetragonophylla, cross-section of phyllode, semi-diagrammatic, $\times 85$.

17. Casuarina stricta, transverse section, semi-diagrammatic, of chlorophyll-bearing stem, $\times 72$. The chlorenchyma is shown partly protected by the heavy epidermis and partly by the furrows with the trichomes, of which the latter are not shown. The enlarged outer ends of the sclerenchyma also act in the same capacity.

18. Eremophila alternifolia, detail of young stem with glandular trichome, $\times 52.5$.

19. Same. Transverse section of leaf showing old glandular trichome, heavy epidermis, and its covering of a resinous substance.

20. Eremophila freelingii, semi-diagrammatic transverse section of leaf to show the size and frequency of internal glands $(g l), \times 52.5$.

21. Eremophila rotundifolia, longitudinal section, semi-diagrammatic, $\times 52.5$, to show the relatively large internal glands and the very heavy covering of hairs $(t r)$.

22. Fusanus acuminatus, fragment of leaf showing chlorenchyma and a group of tracheids, $\times 350$.

23. Same. Crass-section of leaf to show the heavy epidermis consisting of two layers of cells, $\times 350$.

24. Gravillea stenobotrya, semi-diagrammatic transverse section of leaf. The various tissues are as indicated. Trichomes and stomata are confined to the ventral side, $\times 52.5$.

25. Same. Detail of leaf, dorsal side, in cross-section, to show the greatly elongated epidermal cells and well-marked palisades, $\times 350$.

26. Hakea leucoptera, leaf fragment, in transverse secticn, with very heavy epidermis and deeply sunken stoma and papillate processes in stomatal canal. The presence of sclerenchymatous fibers in the palisade chlorenchyma is shown. $\times 350$.

27. Hakea multitineata, semi-diagrammatic cross-section of leaf. The prominent development of mechanical tissue and dorsiventral nature of the leaf structure are indicated. $\times 52.5$.

28. Same. Fragment of leaf, cross-section, to show heavy epidermis, deeply sunken stoma, and pronounced palisade character of the chlorenchyma, $\times 350$.

29. Pittosporum phyllyrooides, fragment of dorsal side of leaf, transverse section, to show the 2- or 3-layered epidermis, $\times 350$.

30. Same, ventral side of leaf. The heavy outer epidermal wall, the single cell layer of the epidermis, and the superficially placed stoma are indicated. $\times 350$.

31. Triodia irritans, transverse section of leaf, semi-diagrammatic, showing its infolded condition and the position and relative abundance of the main tissues, $\times 85$.

In figures 12 to 31 the tissues are designated as follows: $c h$, chlorenchyma; $f x$, conductive tissue; $g l$, internal gland; $h d$, hypoderm; $s c$, sclerenchyma; $e p$, epidermis; $f v$, fibro-vascular tissue. 


\section{PLANT HABITS AND HABITATS IN THE ARID PORTIONS 0F SOUTH AUSTRALIA.}

\section{INTRODUCTION.}

Australia, especially South Australia, holds much of interest to the student of the vegetation of arid regions. Where rain is abundant plants compete with one another in a very real way for room in which to live and for sunlight by which they gain energy for various life processes, but in regions of scanty rainfall, as in portions of South Australia, there is abundance of room and of light. Here the "struggle" is associated with the water relation; it is that of the individual plant with an arid environment, and not individual with individual. When viewed from this standpoint the island continent is seen to be the field of a vast botanical experiment in which may be observed the reaction of numerous species and innumerable individuals to a physical environment, a leading characteristic of which is a relatively small watersupply. Moreover, owing to the great age of Australia, it is possible that nowhere else have plants been exposed to and influenced by an arid environment for a longer period of time.

The physical background of the Australian plants is in a measure unique. The dry region is very extensive. Some idea of its size can be had by the statement that it has nearly as great an area as all Arabia, and as a matter of fact is larger than all other regions of the kind south of the equator. Living and developing under an environment of which the keynote is aridity, the flora of the continent as a whole bears a xerophytic stamp and appears to possess a degree of uniformity which constitutes one of its most marked characteristics. Wherever one goes in Australia, he encounters trees and shrubs with leathery, evergreen leaves. In the better-watered portions the trees are large and numerous and there is an extensive transpiration surface, but in portions less favored in this particular the trees are not large, a shrubby type of vegetation prevails, and the transpiration surface is also much restricted in area. Between the two extremes there are innumerable intermediate conditions in which the gradations are quantitative rather than qualitative. When studied in some detail, however, there may be found a bewildering variety of adjustments to the environment, often monotonous perhaps in outward appearance, and which have in a measure the force of belying the generalization just made.

The physical and biological complexes which enter into our conception of what constitutes an arid, more especially a desert, region are made up of many features. It is true that they center around the important factor of a small water-supply, but they all should be logically included in any definition of such regions with scanty rainfall. 
Owing, however, in part to the difficulty in evaluating the biological value of the accessory factors, such as light intensity, relative humidity of the air, rate of evaporation, and temperature of the air, and in part to the fact that such secondary factors may change in relative force with changes in the amount of the rainfall, it is difficult to express adequately what constitutes a "desert," or even the degree of aridity. Nevertheless it is important to have some method of comparison. Thus, the extremes in amount of rainfall have been used (MacDougal, 1914:175), and the amount of evaporation for any given year has been compared with the precipitation for the same year, and, finally, comparisons have been instituted between the moisture content of the soil and the rate of evaporation of the air (Shreve, 1915:92).

The intensity of the aridity has also been expressed biologically in terms of the relative number of annuals in a region (Paulsen, 1912:159). It was not convenient in the present instance to use these methods, but it appeared necessary nevertheless (mainly for convenience in reference) to have some ready means of comparing one region studied with another, and in the end the device was resorted to of using the rainfall only. An arbitrary classification of regions based on the amount of rain was consequently adopted, which is as follows: A region having 5 inches, or less, of rain annually is a desert; one with a rainfall between 5 and 10 inches is arid; and a region in which the amount of rain is between 10 and 15 inches is semi-arid. In all cases, therefore, in which reference is made in the text to regions so designated the appropriate rainfall will at once be understood.

The study of plants in the field may be said to proceed mainly along threelines, which, although more or less intermingled, are fundamentally quite different. Thus, the leading emphasis can be placed on the plants as species, and their occurrence (local as well as general) can merely be catalogued; this is plant geography in a narrow sense. Or, the mutual relationships of plants can be investigated; this is one formal branch of plant ecology. Or, finally, the investigation can take into consideration mainly the relations of plants to the physical environment in which they are placed; this third phase of the general subject is intimately related to experimental researches along lines suggested by field observations and is not to be dissociated from laboratory studies; this can be referred to as physiological plant ecology. It is the last type of ecological research which the writer has had especially in mind when making field studies, and though it has not been practicable to carry out direct experiments on subjects suggested by the observations, it has been of interest and profit to interpret the observations so far as possible in the light of experimental results already accomplished on analogous lines and with analogous plants by various researchers.

In addition to viewing the living plants from a physiological standpoint, another point of view has been of use, the comparative. In all instances the plants observed have been studied in the light of the 
writer's previous experiences in the dry portions of North America, in southern Algeria, and in portions of Egypt, and these experiences have been of incalculable assistance in attempts at interpreting the various features of Australian plant life observed.

It is impossible adequately to acknowledge the very many kindnesses shown the writer while in Australia. A friendly and helpful spirit of assistance and cooperation was shown by a large number and on very many occasions; but especial acknowledgment must be given Professor and Mrs. T. G. B. Osborn, of the University of Adelaide, who helped greatly to make the visit pleasant as well as profitable. Dr. and Mrs. R. S. Rogers, of Adelaide, well known for their studies on the Orchidaceæ, acted as guides on several botanical excursions into the Mount Lofty Ranges, and in other ways were helpful. J. M. Black esq., of Adelaide, an authority on South Australian plants, very kindly determined those plants which were collected by the writer. Among them Mr. Black found some new stations and a species of Kochia collected at Copley which was previously undescribed. Mention should also be made of the assistance of Alfred Cocks esq., of Adelaide, the former proprietor of "Wilgena" station, near which Tarcoola is situated, whose acquaintance with the "back blocks" of the state is very extensive. Thomas Gill esq., of Adelaide, was of assistance in procuring for the writer useful works on Australian exploration and in other ways; C. S. Owen-Smith esq., of Adelaide, was also helpful in various ways; and finally, not to mention others, G. A. Hobler esq., and Capt. E. W. Saunders, of the Commonwealth railways, kindly placed conveniences at the writer's disposal at Ooldea, and were of much assistance in other ways and at other times.

Especial acknowledgment must be made of permission to use figures, tables, or data for the presentation of many characteristics of the physical environment of the South Australian plants. Figure 1 is from Australia, 1916, by Professor J. W. Gregory; figure 10 is an adaptation of a figure in the Geography of South Australia, 1909, by Howchin and Gregory. Those noted as being from Hunt are by H. A. Hunt esq., Commonwealth meteorologist, and have been taken from various publications of the Commonwealth Bureau of Meteorology. The figures from Taylor are by Dr. Griffith Taylor, physiographer, Commonwealth Meteorological Office, and are in part from publications of the bureau and in part from other publications as noted. As a whole the figures were prepared to serve other than botanical ends and in most of them some changes have been made, inconsiderable in certain instances, to suit the needs of the present study. Figure 11 is based on data supplied by the Adelaide office of the Commonwealth Bureau of Meteorology. In the main the climatological data were supplied by the Commonwealth Bureau or were derived from its publications, and in either case acknowledgment is made explicitly in the course of the study. 
The following species, determined by J. M. Black esq., were collected at Oodnadatta, Copley, Quorn, Port Augusta, Tarcoola, and Blanchtown, and in the regions contiguous to these places:

Acacia aneura F. v. M. brachystachya Benth. calamifolia Sweet. cambadgei R. T. Bake. colletioides A. Cunn. continua Benth. hakeoides A. Cunn. iteaphylla F.v. M. kempeana F. v. M. linophylla W. V. Fitz. oswaldi F. v. M. pycnantha Benth. randelliana W. V. Fitz. rigens $\mathrm{A}$. Cunn. salicina Lindl. sentis F. v. M. stenophylla A. Cunn. sublimata Benth. tarculiensis J. M. Black. varians Benth.

Atriplex mumularium Lindl. quinii F. v. M. spongiosum F. v. M. vesicarium Hew.

Bassia echinopsilla F. v. M. lanicuspis F. v. M. paradoxa F. v. M.

Bossiæa walkeri F. v. M.

Bursaria spinosa Cavan.

Calandrinia pusilla Lindl.

Callistemon teretifolius F. v. M.

Callitris robusta $\mathrm{R}$. Br.

Cassia artemioides Gaud. brownii R. Br. eremophila A. Cunn. sturtij R. Br.

Cassinia aculeata (Lab.) R. Br.

Casuarina lepidophloia F. v. M. stricta Ait.

Cheilanthes tenuifolia Schwartz.

Dodonæa attenuata A. Cunn. bursarifolia Behr et F. v. M. lobulata F. v. M.

Enchylæna tomentosa R. Br.

Eremophila alternifolia R. Br. brownii F. v. M.

freelingii F. v. M. latrobei F. v. M. longifolia F. v. M. neglecta J. M. Black. oppositifolia R. Br. paisleyi F.v. M. rotundifolia F. v. M.

Eucalyptus incrassata Lebill. var. dumosa Maiden.

odorata F. v. M. oleosa F. v. M. rostrata F. v. M.
Eutaxia empetrifolia Schlecht.

Exocarpus aphylla R. Br. spartea R. Br.

Fusanus acuminatus $\mathrm{R}$. Br. spicatus $\mathrm{R}$. $\mathrm{Br}$.

Geigera parviflora Lindl.

Glycine clandestina Wendl.

Gravillea stenobotrya F. v. M.

Hakea leucoptera R. Br. multilineata Meiss.

Helichrysum spiculatum D. C.

Heterodendrum olæefolium Desf.

Indigofera australis Wild. var. minor Benth.

Jasminum lineare $\mathrm{R}$. $\mathrm{Br}$.

Kochia cannoni J. M. Black (n. s.)

decaptera F. v. M.

eriantha F. v. M.

planifolia F. v. M.

pyrmidata Benth.

sedifolia F. v. M.

villosa Lindl.

Leptospermum lævigatum F. v. M. var. minus.

Loranthus exocarpi Behr.

linearifolius Hook.

pendulus Sieb.

quandang Lindl.

Melaleuca glomerata F. v. M. parviflora Lindl.

Menkea australis Lehm.

Myoporum platycarpum $\mathrm{R}$. $\mathrm{Br}$.

Nicotiana suaveolens Lehm.

Nitraria schoeberi L.

Olearia muelleri Benth. pimeleoides Benth. pannosa Hook.

Pholidia santalina F. v. M. scoparia R. Br.

Pimelea microcephala R. Br.

Pittosporum phillyræoides D. C.

Rhagodia parabolica $\mathrm{R}$. $\mathrm{Br}$.

Salicornia tenuis Benth. (n. s.?).

Screvola collaris F. v. M.

Senecio anethifolius A. Cunn. gregorii F. v. M. magnificus F. v. m.

Sida corrugata Lindl.

Solanum ellipticum R. Br.

Templetonia aculeata Benth. egena Sweet.

Trichinium incanum $\mathrm{R}$. Br. spathulacum R. Br.

Triodia irritans $\mathrm{R}$. Br.

Zygophyllum billardieri D. C. crenatum F. v. $M$. fruticulosum D. C. prismatothecum F. v. M. 


\section{PHYSICAL ENVIRONMENT OF THE VEGETATION OF}

\section{AUSTRALIA.}

The vegetational environment of Australia, including the more arid portions, has a complex geographical background. The island continent is separated biologically, as well as physically, from other continents and has been so separated for an immense period of time. Long geological ages also have passed since a large portion of the surface was covered by the sea. The physiography is relatively monotonous, as might be expected from the fact that possibly the area may be regarded as a vast peneplain. The latitudinal situation also is of importance in influencing, really in shaping, the leading characteristic of its climate. Projecting as it does far into the interior, the state of South Australia shares in the general physical characteristics of the continent, but it also holds in certain regards a peculiar relation to the sister states. Its southern shores are washed by the cool seas, while the northern boundaries are parched and baked under a tropic sun. It has the most typically continental climate of all the states (Howchin and Gregory, 1909:17). Such are some of the features which have constituted and which now constitute the broad characters of the physical environment of the vegetation of Australia, including that of the central state, and under which by physiological reactions there has slowly developed the vegetation familiar to us at the present day.

\section{GENERAL PHYSIOGRAPHICAL CONDITIONS.}

The general physiographical conditions of Australia have many points of interest in connection with the present paper. Gregory (1916:25-27) states that:

"Australia as a whole is a great plateau land. It is a fragment of a large continent, the rest of which has been snapped off along great fractures. . . The mountain system is not determined by any dominant lines of folding of the earth's crust, like those which have formed the Alps and the Himalayas. Australia was folded at an early period in the earth's history; and all its ancient fold-mountains have long since been worn down. The chief existing features in the relief of Australia are due to vertical earth-movements, by which some parts of the area have been raised to high plateaus and others have sagged downward into deep basins. The margins of the plateaus have been carved into valleys. . . . The eastern margin of the old plateau has been dissected by powerful streams into deep valleys, which are separated by steep-sided and flat-topped ridges; and in some districts river erosion has been so active that very little of the original surface has been left.

Western Australia, on the other hand, owing to its smaller rainfall and feebler rivers, retains more of the old plateau surface. . . . The inner part of the plateau is a vast gently undulating country, with low rounded hills, except where some hard wind-etched boss of rock rises abruptly from the plains. Wide, shallow depressions run together like the converging branches of a river; and these valleys are divided by the irregularities of their floors into basins, which in wet seasons may contain lakes of little depth; but usually they are 
sheets of salt-incrusted clay, or damp mud and salt marsh. . . . Owing to the absence of recent fold mountains the relief of the continent depends on the weathering of the old plateau and the formation of highlands and lowlands by the uplift or subsidence of wide tracts of country."

The same writer divides the continent of Australia into the Eastern Highlands, the Great Plains, and the Western Plateau. The relative extent and position of each division is indicated in figure 1. It

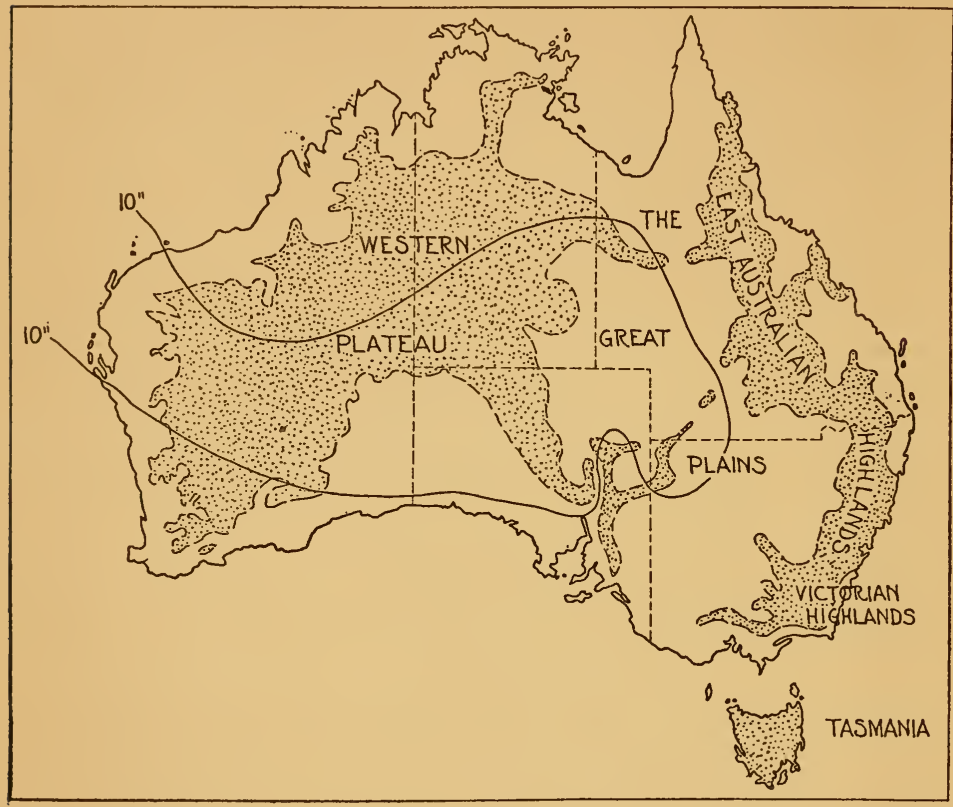

FIg. 1.-Physical divisions of Australia, after Gregory, 1916, to which has been added the 10-inch isohyet. The shaded areas have an altitude of 1,000 feet or more above the sea.

will be seen that the desert-arid regions lie in the western and central divisions and that possibly half of the area within the 10-inch isohyet has an altitude of 1,000 feet or more. On the other hand, a not inconsiderable proportion of the whole of the desert-arid regions is situated in the artesian basin of the Great Plains regions and is below the level of the sea.

The Western Plateau is not level, but several mountain chains rise upon it; certain of these attain to considerable altitude, as, for example, Mount Woodrofe, of the Musgrave Range, which is over 5,000 feet above the sea, approximately 3,000 feet higher than the surrounding plain (Jack, 1915). 
To quote Jutson (1914:20), the interior of the great plateau is arid and has no permanent rivers. The drainage runs into shallow basins (with no outlet except at times of great flows of water), called "salt" or "dry" lakes. There is, however, fresh water to be found where the catchment has been suitable, as, for example, the "soaks" like the wellknown one at Ooldea, and basins in the rocks, as vividly described by Carnegie (1898:191). But, with the possible exception of the former, these have no significance so far as the vegetation is concerned. As the interior has little rain and no rivers, there is no water table. The picture that the great plateau presents as a whole is therefore a very arid one, both as regards the aerial and the subaerial plant environment.

The great plateau is regarded by Jutson (1914:20-21) as being an old, uplifted surface, a vast peneplain, whose surface has been much destroyed, planed down, and often not recognizable. In the southern half of Western Australia the rocks of a very large area are probably pre-Cambrian, while in the southeastern corner they are Mesozoic or early Tertiary (Jutson, l. c.), which is the region known as the Nullarbor Plains. Where the great plateau of the western part of the continent joins the big central artesian basin, the rocks are also of the Mesozoic and more recent ages. As a whole, therefore, the great plateau is of very great geological antiquity.

That portion of the desert-arid region which lies within the Great Plains varies in altitude from somewhat below the level of the sea to 1,000 feet or more above it. One of the characteristic physiographical features is the presence of steppes (Spencer and Gillen, 1912:5) or table-lands of Upper Cretaceous and Lower Cretaceous formations (Jack, 1915:13), which connect the Great Plains to the Western Plateau. On the east the plains gradually rise to the highlands of eastern Australia. The sandhills, which are especially to be found to the north and east of Lake Eyre, but occur to the northwest as well, are built of material derived by erosion from the desert sandstone of the steppes, and the "gibber" plains, or stony deserts, also trace their origin to these Cretaceous plateaus and are the residue remaining in place.

A most striking feature of the Great Plains regions is the presence of several large lakes which in earlier geological times contained fresh water but are now saline wastes, usually carrying water only after heavy rains. Of these, Lake Eyre and Lake Eyre South are the largest, covering an area of 5,000 square miles when filled with water (Howchin and Gregory, 1909: 100). Lake Eyre receives the discharge of several rivers of intermittent flow. At various places in the Lake Eyre basin natural artesian wells are found whose outlets are raised into small hills through the deposition of minerals held in solution. Also, numerous "bores," deep wells, have been sunk for economic purposes. The water that supplies the wells of whatever sort is derived from rains falling in the Eastern Highlands or is chiefly plutonic (Pittman, 1914). 


\section{FEATURES OF THE CLIMATE OF AUSTRALIA.}

\section{RAINFALL.}

There are four major rainfall regions in Australia, according to Taylor $\left(1918^{2}: 10\right)$, namely, the summer-rain region of the north, the winterrain region of the south, a region of uniform rains in the east, and a region of little rain in the center and middle west. The seasonal shifting of the climatic complex north-south, following the declination of the sun, operates to bring about the seasonal rains. Tropical storms, cyclones, reach inland in summer and cover the entire northern portion of the continent. They extend south barely as far as Oodnadatta. The winter storms, on the other hand, affect the southern portion and extend north only about as far as Farina, South Australia (Taylor, $\left.1918^{2}: 10\right)$. These accompany the northern extension of the prevailing westerlies which in summer are far to the south of Australia. There is, therefore, a belt of territory running roughly east and west which is beyond the usual reach either of the winter or of the summer rains. This dry central region comprises, according to Taylor, 37 per cent of the area of the continent.

TABLE 1.-Rainfall at the capitals.

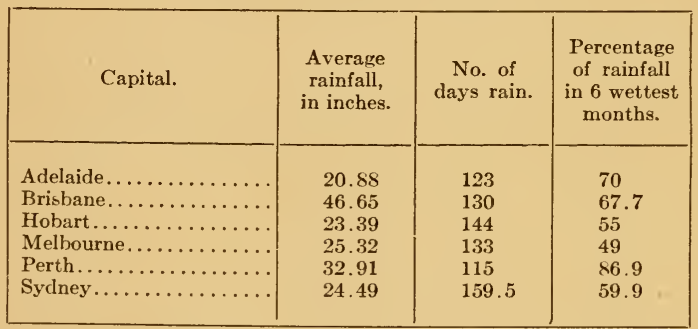

The leading characteristics of the rainfall in the humid regions can be illustrated by that at the capitals of the different states. These are summarized in table 1. At Adelaide and at Perth rain occurs mostly in the winter season; at Brisbane it is mostly in summer; at Sydney it is mostly in late summer, autumn, and early winter, while at Melbourne and at Hobart it is fairly evenly distributed throughout the year.

So far as the well-being of the vegetation as a whole is concerned the reliability of the rains (or the want of this) is of capital importance. And in a general way the reliability of the rains decreases with the decrease in the amount of the rainfall, which it will be seen only serves to intensify the effects of progressive aridity. Thus we find that in the dry interior of the continent there is a mean variation equal to 40 to 50 per cent from the normal (Taylor, $1918^{1}$, fig. 4.) In some years very little rain falls at any season, while in others almost the entire yearly rain may fall within a few hours. While the rainfall throughout the interior is as a rule very unreliable, the portion of the dry mid-region 
which has the least reliable rainfall, according to the same author, is in Western Australia. At Roeburn, for example, the following extremes in precipitation have been recorded: In the year 1891 the rainfall was 0.13 inch only; in the year 1900, at the opposite extreme, the rainfall amounted to 42 inches. The region of greatest rain variability is roughly equal in extent to that which lies within the 10-inch isohyet, but it is situated somewhat farther north and hence is largely in the region of summer rains.

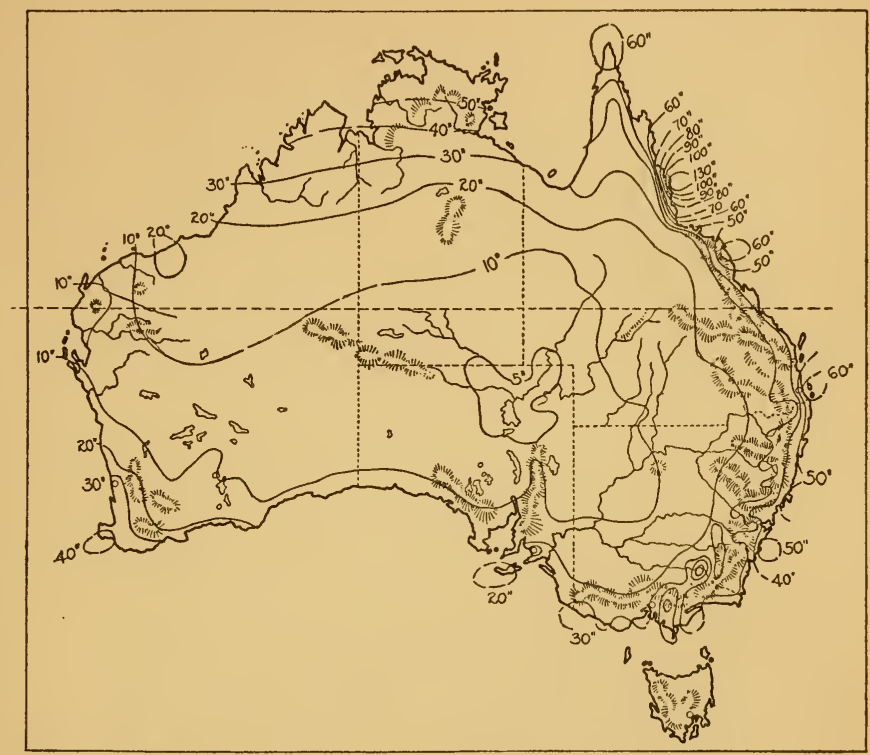

Fró. 2.-Mean annual rainfall map of Australia, adapted from Hunt.

It can be seen that with the possible exceptions of the dry interior on the one hand and the humid regions on the other, the precipitation of the continent can be characterized as periodic. There are thus many days in the year when no rain falls and, as just suggested, these may occur in large degree consecutively. The actual number of rainless days may be surprisingly large, as the following will indicate; the figures are for the year 1912 only: In the humid regions the average number of days without rain for 26 stations is 306.2. In the semi-arid regions the average of 24 stations is 332 rainless days, the average for 16 stations in the arid regions is 328.4 , and finally, the average number of rainless days in the desert, 6 stations, is 346.4 . It is possible that the regular recurrence of rainless periods over most of Australia is a very important factor, although a very complex one, in giving the vegetation as a whole the xerophytic stamp it bears. 
TABLE 2.-Mean monthly and annual rainfall (in inches).*

\begin{tabular}{|c|c|c|c|c|c|c|c|c|c|c|c|c|c|}
\hline & Jan. & Feb. & Mar. & Apr. & May. & June. & July. & Aug. & Sept. & Oct. & Nov. & Dec. & Year. \\
\hline \multicolumn{14}{|l|}{ Oodnadatta: } \\
\hline Mean..... & 0.71 & 0.71 & 0.57 & 0.18 & 0.23 & 0.64 & 0.28 & 0.11 & 0.32 & 0.34 & 0.38 & 0.38 & 4.85 \\
\hline Highest. & 5.18 & 4.16 & 4.32 & 1.79 & 1.54 & 2.77 & 1.68 & 0.60 & 2.21 & 2.03 & 1.41 & 1.79 & 8.92 \\
\hline Lowest....... & 0.0 & 0.0 & 0.0 & 0.0 & 0.0 & 0.0 & 0.0 & 0.0 & 0.0 & 0.0 & 0.0 & 0.0 & 1.54 \\
\hline \multicolumn{14}{|c|}{ Leigh's Creek: } \\
\hline (Copley) Mean & 0.67 & 0.52 & 0.80 & 0.54 & 1.06 & 1.11 & 0.50 & 0.69 & 0.75 & 0.47 & 0.53 & 0.76 & 8.40 \\
\hline Highest....... & 4.76 & 3.05 & 4.70 & 3.78 & 5.84 & 4.72 & 2.24 & 3.02 & 3.58 & 2.06 & 2.35 & 3.78 & 15.6 \\
\hline Lowest.. & 0.0 & 0.0 & 0.0 & 0.0 & 0.0 & 0.0 & 0.0 & 0.0 & 0.0 & 0.0 & 0.0 & 0.0 & 1.95 \\
\hline \multicolumn{14}{|l|}{ Quorn: } \\
\hline Mean... & 0.64 & 0.45 & 0.61 & 0.96 & 1.58 & 2.03 & 1.57 & 1.84 & 1.30 & 1.32 & 0.87 & 0.65 & 13.8 \\
\hline Highest. & 3.20 & 2.53 & 3.53 & 6.38 & 6.86 & 4.88 & 6.15 & 5.53 & 4.00 & 4.44 & 5.36 & 2.45 & 25.7 \\
\hline Lowest. & 0.0 & 0.0 & 0.0 & 0.0 & 0.01 & 0.23 & 0.14 & 0.06 & 0.0 & 0.09 & 0.0 & 0.0 & 7.43 \\
\hline \multicolumn{14}{|l|}{ Adelaide: } \\
\hline Mean... & 0.72 & 0.63 & 1.06 & 1.85 & 2.71 & 3.10 & 2.65 & 2.50 & 1.98 & 1.72 & 1.17 & 0.96 & 21.0 \\
\hline Highest. & 4.00 & 2.67 & 4.60 & 6.78 & 7.75 & 8.58 & 5.38 & 6.24 & 4.64 & 3.83 & 3.55 & 3.98 & 30.8 \\
\hline Lowest... & 0.0 & 0.0 & 0.0 & 0.06 & 0.20 & 0.42 & 0.36 & 0.35 & 0.45 & 0.17 & 0.04 & 0.0 & 11.3 \\
\hline \multicolumn{14}{|l|}{ Kalgoorlie: } \\
\hline Mean.... & 0.43 & 0.73 & 0.90 & 0.78 & 1.31 & 1.27 & 0.91 & 0.90 & 0.52 & 0.79 & 0.58 & 0.62 & 9.74 \\
\hline Highest. & 2.50 & 4.68 & 5.02 & 3.43 & 3.12 & 3.00 & 2.08 & 3.18 & 3.29 & 3.14 & 2.76 & 2.57 & 16.4 \\
\hline Lowest. & 0.0 & 0.0 & 0.0 & 0.0 & 0.0 & 0.0 & 0.22 & 0.0 & 0.0 & 0.0 & 0.0 & 0.0 & 4.75 \\
\hline
\end{tabular}

* Supplied by the Commonwealth Bureau of Meteorology, Central Bureau, Melbourne.

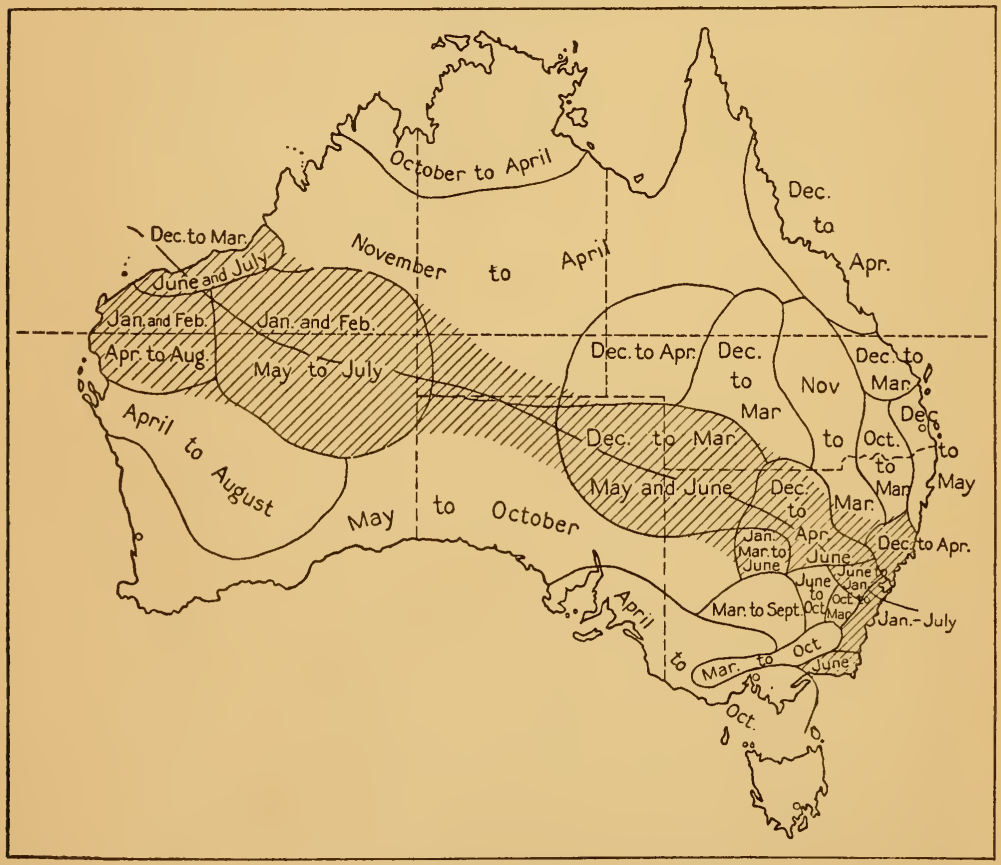

Fra. 3a.-Duration of wet seasons, after Taylor, 1916. "The periods shown on the map include those months in which the average rainfall exceeds the geometric mean of monthly rainfalls." 


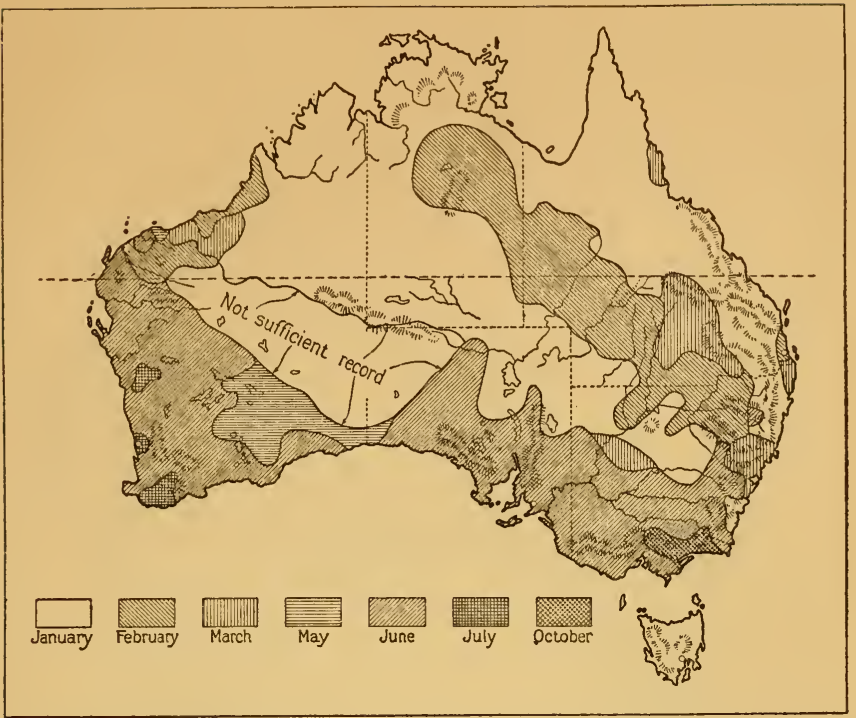

Fra. 3b.-Wettest months of year, after Hunt's meteorological map of Australia, 1916.

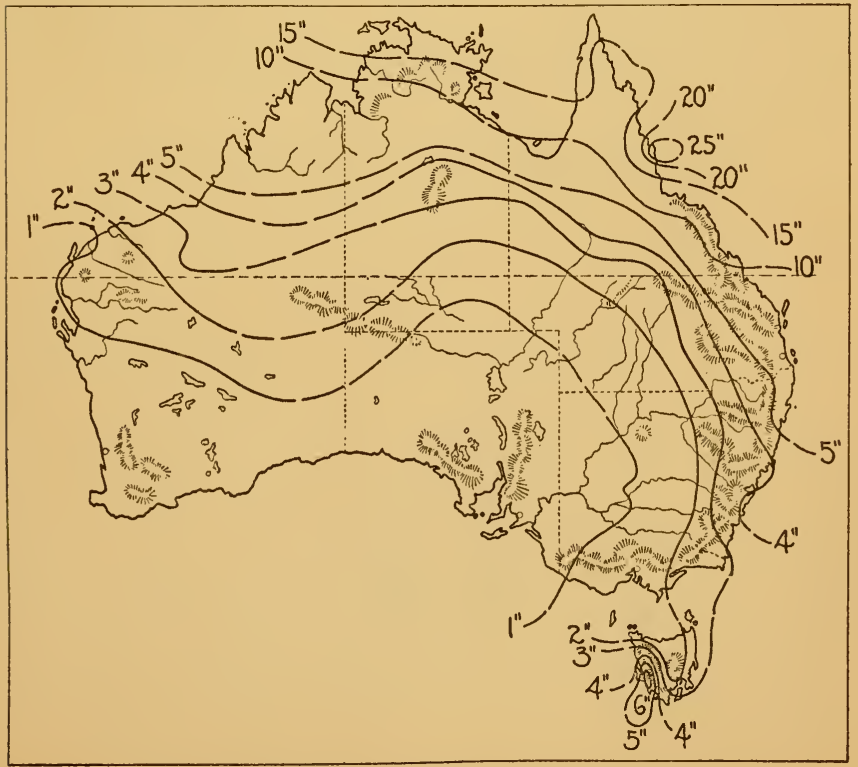

Fra. 4a.-Mean rainfall of Australia for January, after Hunt. 


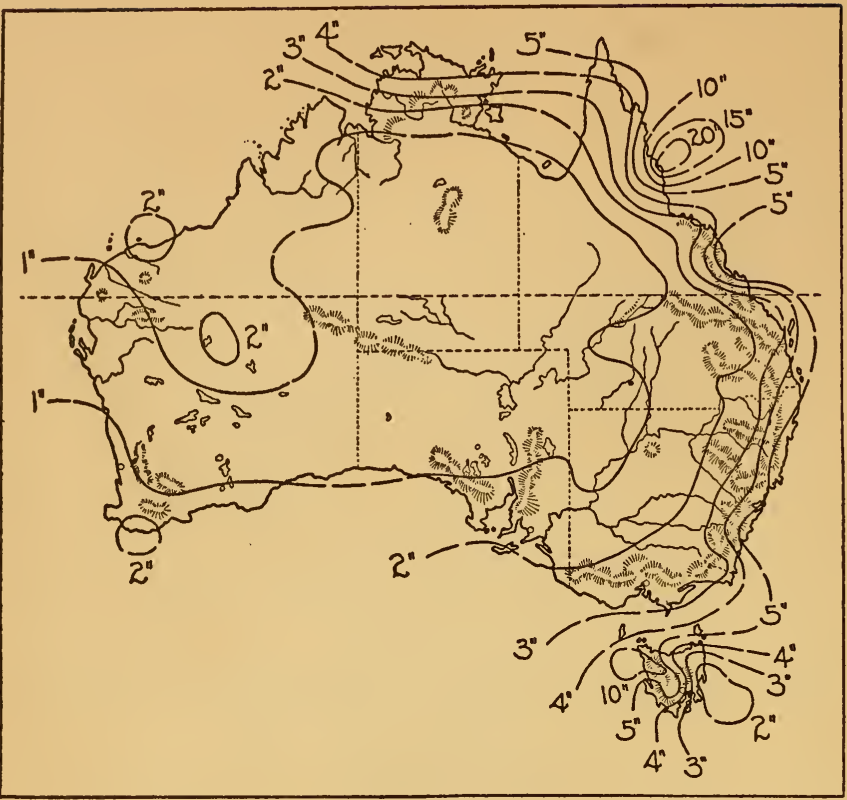

Frg. 4b.-Mean rainfall of Australia for April, after Hunt.

TABLE 3.-Average yearly evaporation and rainfall for representative Australian stations

\begin{tabular}{|c|c|c|c|c|c|}
\hline Station. & $\begin{array}{c}\text { Evaporation, } \\
\text { inches. }\end{array}$ & $\begin{array}{l}\text { Rainfall, } \\
\text { inches. }\end{array}$ & Station. & $\begin{array}{c}\text { Evaporation, } \\
\text { inches. }\end{array}$ & $\begin{array}{l}\text { Rainfall, } \\
\text { inches. }\end{array}$ \\
\hline Perth.. & 66.13 & 33.26 & Broken Hill. . & 85.63 & 9.66 \\
\hline Laverton. & 146.57 & 9.5 & Sydney...... & 36.91 & 48.16 \\
\hline Cue........... & 156.02 & 8.27 & Melbourne... & 38.38 & 25.60 \\
\hline Kalgoorlie........ & 87.74 & 9.40 & Brisbane..... & 51.95 & 47.05 \\
\hline Adelaide... & 54.28 & 21.66 & Hobart.... & 32.37 & 25.50 \\
\hline Alice Springs...... & 97.10 & 10.99 & Wiluna... & 149.67 & 9.94 \\
\hline
\end{tabular}




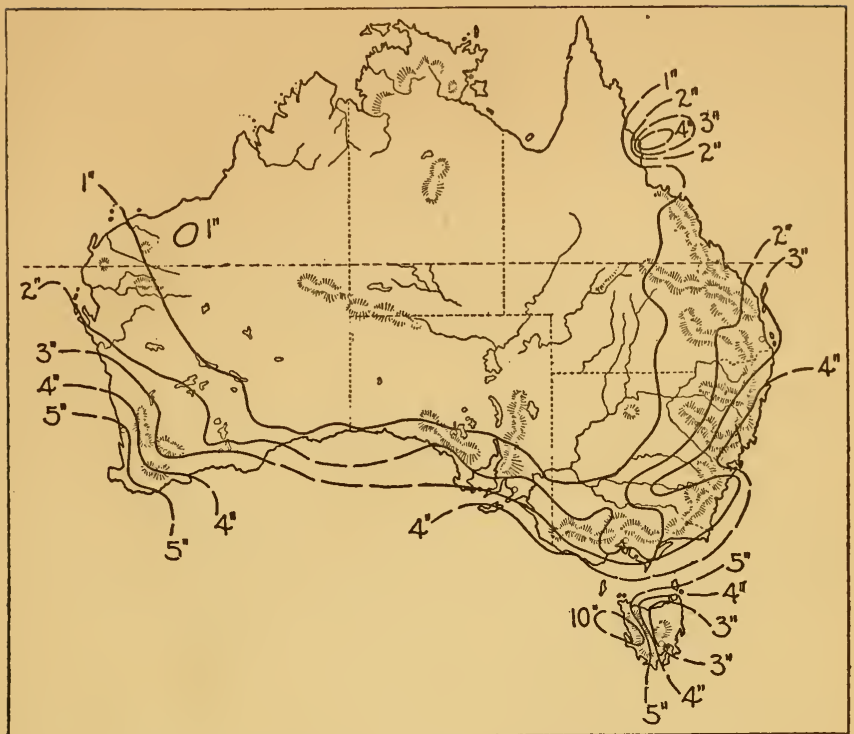

Fig. 5a.-Mean rainfall of Australia for July, after Hunt.

TABLE 4.-Mean monthly and annual evaporation (in inches).*

\begin{tabular}{|c|c|c|c|c|c|c|c|c|c|c|c|c|c|}
\hline & Jan. & Feb. & Mar. & Apr. & May. & June. & July. & Aug. & Sept. & Oct. & Nov. & Dec. & Year. \\
\hline Alice Springs: & & & & & & & & & & & & & \\
\hline & 12.2 & 10.5 & 9.5 & 6.8 & 4.8 & 3.3 & 3.6 & 5.0 & 7.1 & 9.2 & 10.6 & 12.0 & 95.2 \\
\hline Highest $\mathrm{n}$ & 15.4 & 13.8 & 12.6 & 8.4 & 5.5 & 4.1 & 4.4 & 6.4 & 8.5 & 11.7 & 12.8 & 14.1 & 108.4 \\
\hline Lowest mean. . & 8.1 & 6.5 & 6.9 & 5.0 & 3.7 & 2.6 & 2.3 & 3.9 & 5.9 & 5.8 & 8.6 & 8.9 & 84.2 \\
\hline $\begin{array}{l}\text { Adelaide: } \\
\text { Mean..... }\end{array}$ & & & & & & & & & & 4.7 & 6.5 & 8.4 & 544 \\
\hline $\begin{array}{l}\text { Mea } \\
\text { High }\end{array}$ & $\begin{array}{r}8.9 \\
11.2\end{array}$ & $\begin{array}{l}7.3 \\
9.1\end{array}$ & $\begin{array}{l}5.7 \\
7.2\end{array}$ & $\begin{array}{l}3.3 \\
4.9\end{array}$ & $\begin{array}{l}1.9 \\
2.8\end{array}$ & $\begin{array}{l}1.2 \\
1.8\end{array}$ & $\begin{array}{l}1.2 \\
2.3\end{array}$ & $\begin{array}{l}1.8 \\
2.7\end{array}$ & $\begin{array}{l}2.8 \\
3.8\end{array}$ & $\begin{array}{l}4.8 \\
7.3\end{array}$ & $\begin{array}{l}0.5 \\
7.8\end{array}$ & $\begin{array}{r}8.4 \\
10.4\end{array}$ & $\begin{array}{l}54.4 \\
60.9\end{array}$ \\
\hline Lowest mean. . & 7.3 & 4.9 & 4.2 & 2.1 & 1.2 & .8 & .8 & 1.1 & 2.0 & 3.1 & 4.8 & 6.5 & 46.6 \\
\hline Eucla: & & & & & & & & & & & & & \\
\hline Mean & 6.8 & 6.0 & 5.4 & 4.0 & 3.1 & 2.5 & 2.6 & 3.4 & 4.4 & 5.6 & 5.7 & 6.8 & 57.0 \\
\hline Highest mean.. & 7.9 & 7.1 & 6.5 & 4.6 & 3.6 & 3.0 & 3.2 & 4.1 & 5.5 & 7.1 & 6.7 & 8.3 & 60.9 \\
\hline $\begin{array}{l}\text { Lowest mean. . } \\
\text { Coolgardie: }\end{array}$ & 5.7 & 5.3 & 4.1 & 3.2 & 2.6 & 1.9 & 2.3 & 2.7 & 3.9 & 4.7 & 5.2 & 6.4 & 52.8 \\
\hline $\begin{array}{l}\text { Coolgardie: } \\
\text { Mean...... }\end{array}$ & 12,4 & 10.2 & 9.0 & 5.8 & 3.7 & 2.4 & 2.3 & 3.5 & 5.3 & 7.4 & 9.9 & 12.5 & 85.0 \\
\hline Highest mean. & 15.1 & 14.3 & 11.3 & 9.0 & 4.8 & 3.1 & 3.0 & 4.3 & 6.9 & 9.5 & 11.6 & 17.8 & 96.6 \\
\hline Lowest mean. & 8.9 & 6.4 & 6.2 & 3.5 & 1.7 & 1.6 & 1.1 & 2.9 & 3.9 & 4.6 & 6.6 & 9.1 & 71.9 \\
\hline
\end{tabular}

* Supplied by the Commonwealth Bureau of Meteorology, Central Bureau, Melbourne. 


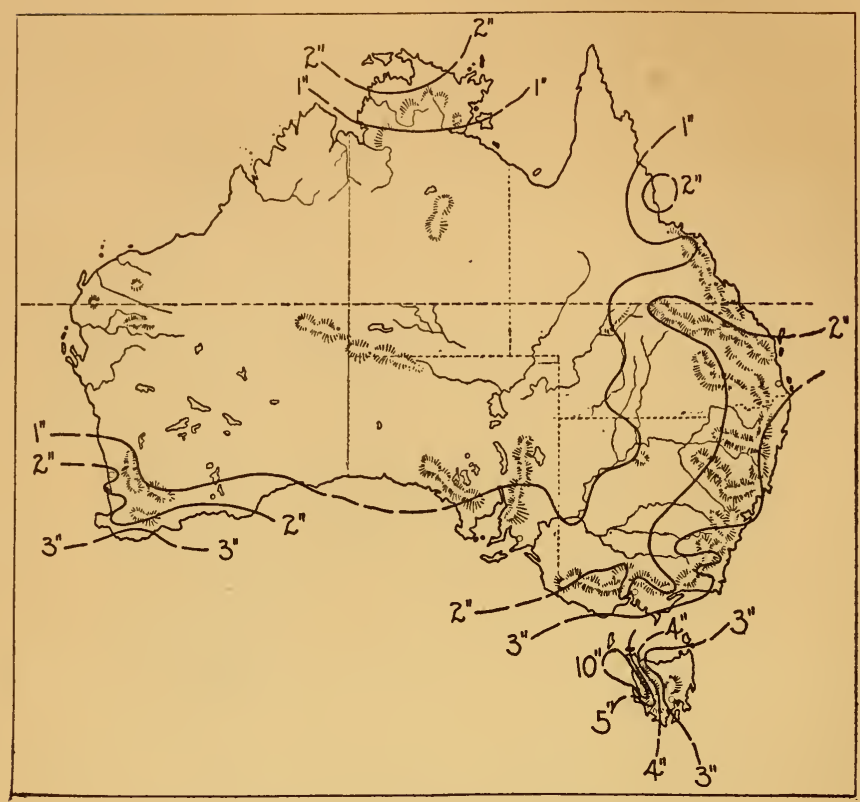

FIG. 5b.-Mean rainfall of Australia for October, after Hunt.

Evaporation.

A relatively high rate of evaporation is one of the most striking features of the Australian climate taken as a whole (table 4 and fig. $8 a$ ). In a large portion of the continent it exceeds the rainfall, and in certain regions, as indicated by table 3 , the difference between evaporation and rainfall may be very great. Moreover, in a fairly large area the annual evaporation is relatively and actually high. Thus in about 40 per cent of the continent the total evaporation is 100 inches or more annually. Since there is a direct relation between the rate of evaporation and the temperature of the air, as well as with other climatic factors, such as relative humidity and rainfall, it follows that there is a regular course run by it during the year. This feature is shown in figure 6 . It will be observed that in regions of winter rainfall the course of the monthly evaporation amount is fairly consistently opposed to that of the rainfall, but that in regions within the zone of summer rains, as at Brisbane, there is more or less coincidence between the course of the two climatic elements. Table 4 is a detailed summary of the mean monthly and annual evaporation amounts, as well as the highest and the lowest means, for 4 stations. 
The region having the highest rate of evaporation is in the western part of the central portion of the continent. At Cue, for example, there is a record of 156.02 inches in one year. This amount far exceeds that reported for Aden, on the Indian Ocean, and Calexico, California (MacDougal, 1914:6), but is not so great as reported for Ghardaia, Algeria, which is 5,309.7 mm. or 17.5 feet (Cannon, 1913:9).

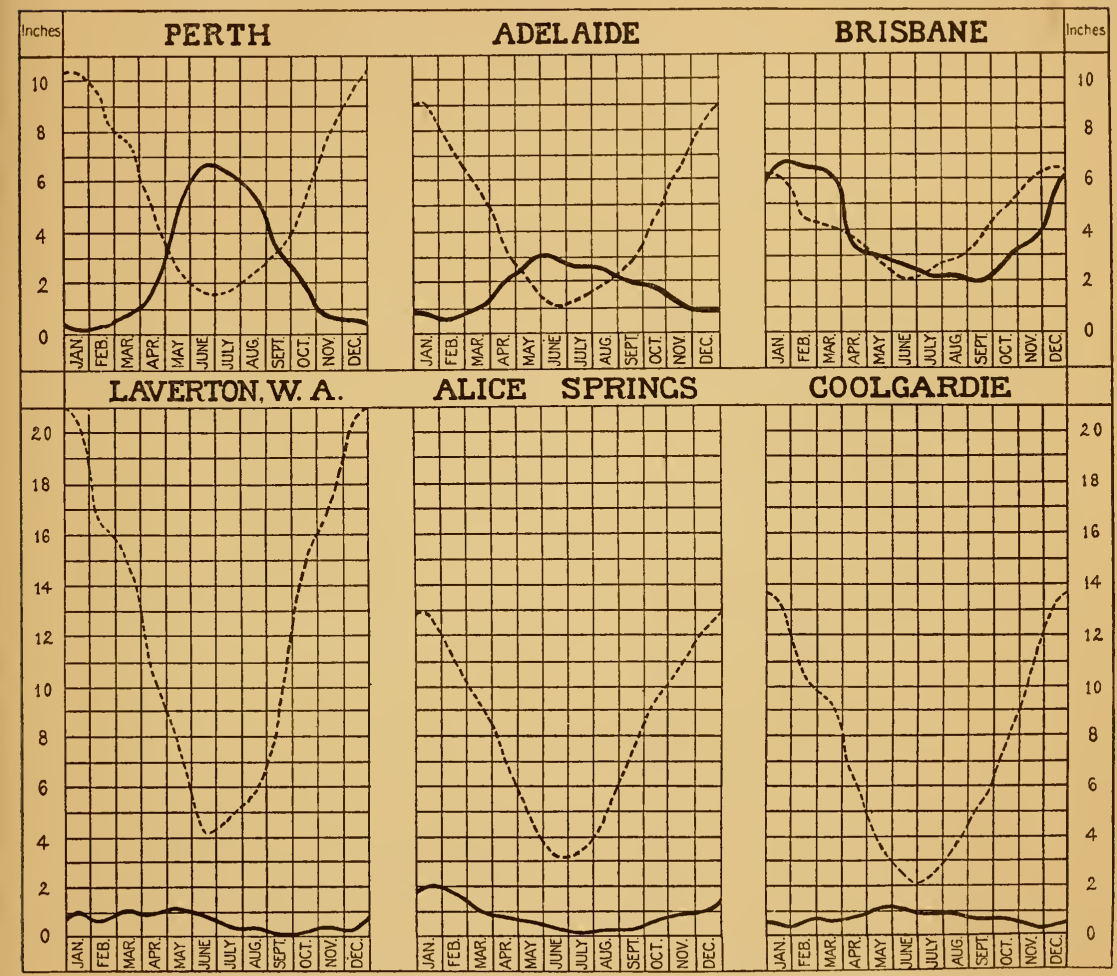

Fig. 6.-Graphs, after Hunt, showing average monthly rainfall and mean monthly evaporation, in inches, for various places in Australia.

\section{Relative Humidity.}

The relative humidity isopleths when plotted on a map of Australia parallel fairly closely the coast-line (Taylor, $\left.1918^{2}: 8\right)$. Hence they are concentric. Other interesting features are the relatively large area which lies within the 40 per cent relative humidity isopleth, which is approximately 27 per cent of the continent, and the changes in area of the region included within this isopleth with its north-south seasonal movement. These features are illustrated in figures $7 a$ and $7 b$. 
The average relative humidity ( $3 \mathrm{p} . \mathrm{m}$. readings) for the year 1912 for arid-subhumid stations, compiled from Hunt (1912), illustrates the wide distribution of the low relative humidities. The average for 13 arid stations gives a relative humidity of 32.3 per cent. The average for a like number of semi-arid stations is 37 per cent. And, finally, the average for 9 subhumid stations is 42.1 per cent.

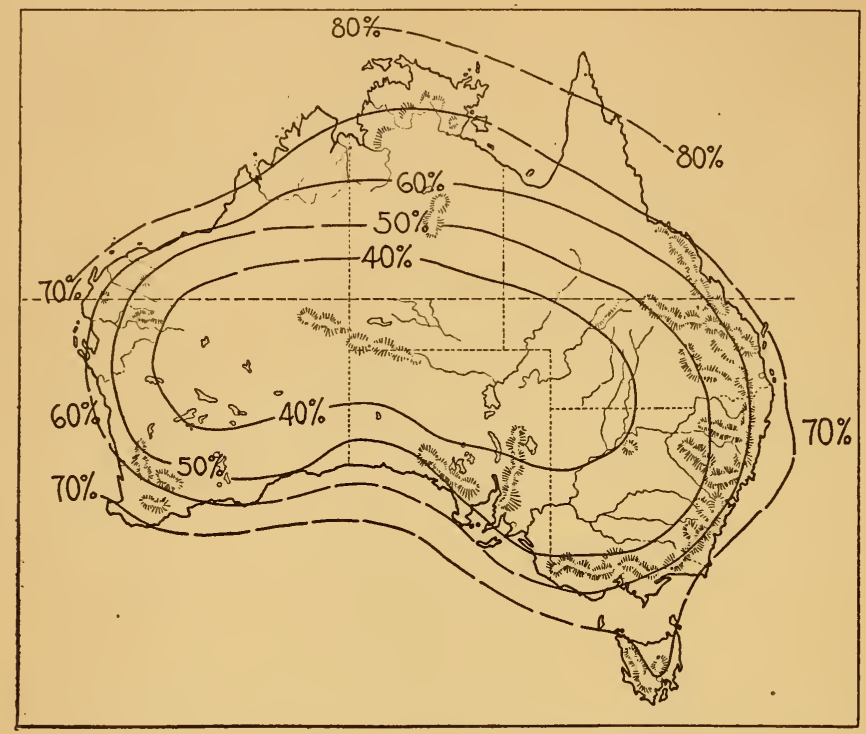

Fig. 7a.-Mean humidity of Australia for Janưary, after Taylor, 1918.

In summer, when the center of minimum relative humidity is farthest south, practically all of South Australia is included within the 50 per cent relative humidity isopleth, and possibly in over one-half of the state at this season the relative humidity averages 40 per cent or less.

\section{LigHT.}

The amount and quality of light to which plants are exposed, as is well known, are extremely variable. The light in humid regions, for example, is less intense and contains less of the more refrangible rays, the blue, violet, and ultra-violet, than that in arid regions. The light in high latitudes is weaker than that of the tropics. From its geographical position, as well as from the fact that much of the continent is relatively and actually arid, it follows that much of Australia is exposed to an intense light, rich in actinic or chemical rays. In the 


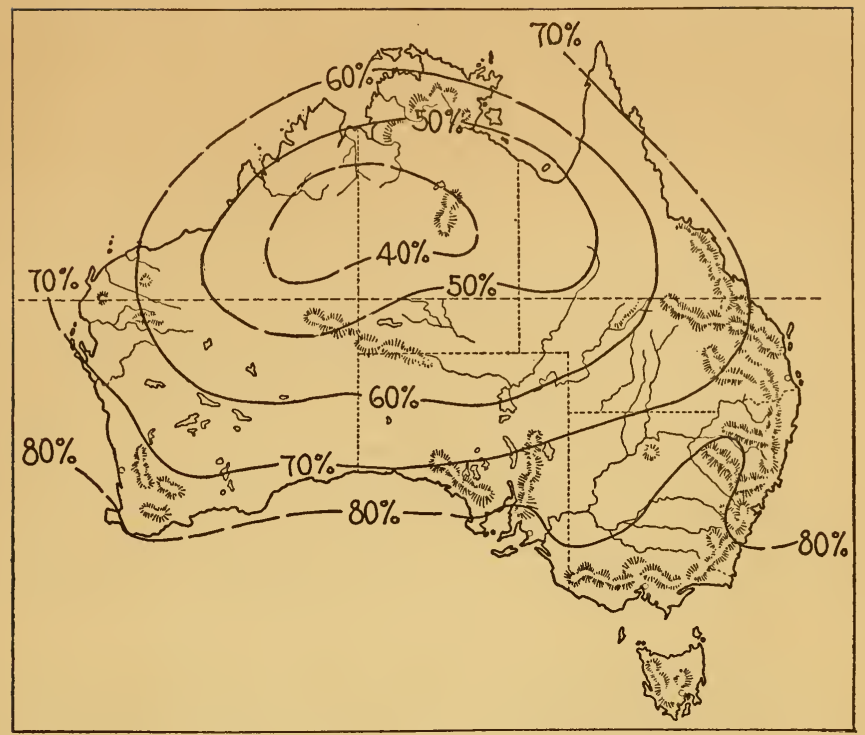

Fig. 7b.-Mean humidity of Australia for July, after Taylor, 1918.

absence of data dealing directly with the subject we may get some idea of the amount of light as well as of its variation in amount over the continent by comparing the number of hours of sunshine at several representative stations (table 5).

TABLE 5.-Hours of sunshine for representative stations in Australia. (Hunt, 1912:625.)

\begin{tabular}{|c|c|c|c|}
\hline Station. & $\begin{array}{c}\text { Total } \\
\text { sunshine } \\
\text { for year 1912, } \\
\text { in hours. }\end{array}$ & $\begin{array}{c}\text { Mean } \\
\text { daily amount, } \\
\text { in hours. }\end{array}$ & $\begin{array}{c}\text { Greatest } \\
\text { daily amount, } \\
\text { in hours. }\end{array}$ \\
\hline Perth..... & $2,834.3$ & 7.7 & 13.2 \\
\hline Adelaide.............. & $2,479.0$ & 6.8 & 13.9 \\
\hline Alice Springs. . . . . . . . . & $3,350.0$ & 9.2 & 12.3 \\
\hline Brisbane................ & $2,758.8$ & 7.7 & 12.7 \\
\hline Sydney............ & $1,984.5$ & 5.4 & 13.5 \\
\hline 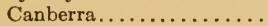 & $2,206.9$ & 6.1 & 12.3 \\
\hline Melbourne............. & $1,862.1$ & 5.1 & 11.3 \\
\hline 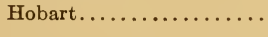 & $1,861.6$ & 5.1 & 11.8 \\
\hline
\end{tabular}

There is an interesting relation between the light and the reaction of the plant to other environmental factors. In regions having little rainfall especially, the exposed surface of plants is reduced in extent so that the amount of water lost is thereby also reduced. This is carried 
to the extreme under desertic conditions. But the plant is under the necessity of manufacturing food through energy, in part derived from light. This calls for a leaf expanse adequate to this end. Therefore forces are in constant operation which, on the one hand, tend to decrease the extent of leaf surfaces, and on the other tend in the opposite direction. But in the arid regions, as has just been remarked, light is abundant and of proper quality, so that a relatively or actually small expanse of leaves, made necessary by the high rate of evaporation, is also sufficient for the manufacture of foods.

According to Schimper (1903:714) light in high altitudes, which may have many of the properties of that of the desert, is very intense and is rich in actinio rays. It operates to retard the growth of shoot axes and of foliage. It induces the construction, on the part of the plant, of certain pigments which may possibly act as a screen, and at the same time it may bring about the more rapid destruction of the chlorophyll. The development of palisade cells is apparently forwarded by such conditions as obtain in the mountains and on the desert, thus tending to increase the xerophytic character of the vegetation characteristic of these regions.

\section{Temperature.}

Australia possesses a very equable climate; indeed, according to Hunt (1914:124), it is the most pacific and equable of all the continents. This in part is owing to its insularity, in part to its geographical position, and in part to the comparatively low relief of its surface. Taylor $\left(1918^{2}: 4\right)$ makes an interesting comparison as to the temperature on parallel degrees of latitude between Australia and the average for each hemisphere. It appears that the Australian tropics are hotter than the average for either hemisphere. On the other hand, the temperate regions of Australia are somewhat hotter than parallel latitudes in other continents of the southern hemisphere, but the opposite is true with regard to Australia and the northern hemisphere. However, one of the hottest regions on the globe, according to the same author, is in Australia. He states that only four localities are known with an average annual temperature over $84^{\circ} \mathrm{F}$. Of these, Timbuctu has an average temperature of $84^{\circ}$; from Massowah to Khartum the average is $86^{\circ}$; Tinnevelly, India, has an average temperature of $84.3^{\circ}$, and, finally, the average at Wyndham, northwest Australia, is $84.6^{\circ} \mathrm{F}$.

In the annual north-south progress of the seasons the $75^{\circ}$ isotherm sweeps nearly the entire continent (figs. $9 a$ and $9 b$ ). The cooling effects of the sea and of the highlands are to be seen in the curving of the isotherms. As a whole, however, the interior has relatively high temperatures. Table 6 gives some of the highest shade temperatures reported in Australia previous to 1912, and probably among the highest reported anywhere. In table 7 are presented data relative to the temperature at several stations, mainly in regions of small rainfall. 
TABLE 6.-Maximum shade temperatures previous to 1912, together with rainfall.

\begin{tabular}{|c|c|c|}
\hline Localities. & $\begin{array}{c}\text { Rainfall, } \\
\text { inches. }\end{array}$ & Temp., ${ }^{\circ} \mathrm{F}$. \\
\hline William Creek....... & 5.46 & 119.0 \\
Marble Bar........ & 13.88 & 120.5 \\
Walgott.......... & 18.9 & 122.2 \\
Strathalbyn........ & 10.05 & 123.2 \\
Bourke........... & 14.44 & 127.0 \\
\hline
\end{tabular}

TABLE 7.-Temperature, $F .^{*}$

\begin{tabular}{|c|c|c|c|c|c|c|c|c|c|c|c|c|c|}
\hline & Jan. & Feb. & Mar. & Apr. & May. & June. & July. & Aug. 5 & Sept. & Oet. & Nov. & Dec. & Year. \\
\hline William Creek: & & & & & & & & & & & & & \\
\hline & 82.9 & 82.8 & 76.4 & 67.3 & 59.2 & 54.0 & 52.3 & 56.4 & 62.5 & 70.3 & 77.0 & 81.5 & 68.6 \\
\hline High & 88.9 & 89.4 & 81.1 & 70.0 & 62.3 & 58.4 & 55.6 & 61.2 & 65.8 & 75.0 & 83.3 & 85.4 & \\
\hline Lowe & 77.0 & 77.3 & $\mid 71.4$ & 63.5 & 55.0 & 49.2 & 48.4 & 53.4 & 56.8 & 62.7 & 71.8 & 76.5 & \\
\hline Abso & $|119.0| 1$ & 115.0 & 110.4 & 101.5 & 93.2 & 81.5 & 82.5 & 95.8 & $|101.0|$ & $110.5 \mid$ & 114.2 & 116.4 & 119.0 \\
\hline Absol & $53.0 \mid$ & 52.5 & 46.0 & 39.0 & 29.2 & 27.5 & 25.8 & 25.3 & 34.5 & 37.0 & 41.0 & 48.0 & 25.3 \\
\hline Mean & 24.4 & 21.6 & 14.4 & 3.0 & 0.3 & 0.0 & 0.0 & 0.1 & 2.1 & 8.8 & 16.4 & 22.9 & 114.0 \\
\hline $\begin{array}{c}\text { Mean } N \\
40\end{array}$ & & & & & & 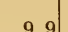 & 15.3 & 8.8 & 1.3 & 0.2 & 0.0 & 0,0 & 40.6 \\
\hline Farina: & 0.0 & 0.0 & 0.0 & 0.1 & 0.0 & & & & & & & & 40.0 \\
\hline & 81.9 & 82.0 & 75.8 & 66.4 & 58.4 & 52.7 & 50.9 & 54.8 & 60.7 & 68.7 & 75.5 & 80.2 & 67.3 \\
\hline & 88.6 & 88.2 & 79.8 & 69.6 & 61.3 & 57.0 & 54.0 & 60.6 & 63.6 & 73.6 & 81.7 & 83.8 & \\
\hline Lov & $77.0 \mid$ & 76.6 & 70.0 & 62.0 & 54.3 & 48.7 & 47.7 & 51.9 & 55.6 & 61.1 & 67.6 & 73.9 & \\
\hline & $118.0 \mid 1$ & 114.3 & 111.1 & 98.0 & 91.5 & 86.0 & 78.0 & 90.5 & 98.2 & 107.0 & 111.5 & 114.2 & 118.0 \\
\hline Absol & 53.2 & 51.0 & 46.5 & 39.1 & 31.7 & 27.3 & 28.3 & 29.6 & 34.0 & $37.0 \mid$ & 42.0 & 47.5 & 27.3 \\
\hline Mean & 23.8 & 21.7 & 14.6 & 2.8 & 0.1 & 0.0 & 0.0 & 0.0 & 1.2 & 7.2 & 15.2 & 21.9 & 108.5 \\
\hline $\begin{array}{l}\text { Mean No. of nights } \\
40\end{array}$ & & & & & & & & & 3,1 & 0.2 & 00 & 0,0 & \\
\hline Point Augusta: & 0.0 & 0.0 & 0.0 & 0.2 & 5.2 & 12.6 & 18.5 & 12.8 & 3.1 & 0.2 & 0.0 & 0.0 & \\
\hline & 77.6 & 78.3 & 73.4 & 66.4 & 59.7 & 54.6 & 52.9 & 55.8 & 60.5 & 66.8 & 72.0 & 75.9 & 66.2 \\
\hline & 83.6 & 84.5 & 77.2 & 71.2 & 63.6 & 57.9 & 55.1 & 60.2 & 63.2 & 71.4 & 77.1 & 80.1 & \\
\hline & 72.8 & 73.5 & 70.0 & 62.4 & 56.4 & 50.6 & 50.4 & 53.0 & 56.0 & 59.3 & 65.3 & 70.7 & \\
\hline & $|114.8|$ & 117.0 & 110.9 & 98.0 & 91.2 & 80.8 & 75.2 & 86.4 & 94.0 & 106.3 & 108.8 & 114.2 & 117.0 \\
\hline & 51.7 & 49.1 & 48.6 & 42.0 & 35.0 & 32.2 & 31.4 & 32.0 & 38.0 & 39.6 & 43.0 & 48.0 & 31.4 \\
\hline Mear & 14.4 & 13.4 & 9.1 & 2.9 & 0.1 & 0.0 & 0.0 & 0.0 & 0.5 & 4.7 & 9.4 & 12.9 & 67.4 \\
\hline Mea & & & & & & & & & & & & & \\
\hline $\begin{array}{r}40 \ldots \\
\text { Adelaide: }\end{array}$ & 0.0 & 0.0 & 0.0 & 0.0 & 0.8 & 3.9 & 7.2 & 4.1 & 0.5 & 0.1 & 0.0 & 0.0 & \\
\hline & 74.1 & 74.1 & 69.9 & 63.9 & 57.7 & 53.4 & 51.6 & 54.0 & 57.0 & 62.0 & 67.0 & 71.1 & \\
\hline & 81.3 & 83.0 & 74.8 & 69.3 & 61.2 & 57.2 & 55.7 & 58.3 & 61.0 & 69.6 & 72.1 & 77.4 & 65. \\
\hline & $67 . \mathrm{C}$ & 69.1 & 65.2 & 59.2 & 54.2 & 49.8 & 49.0 & 49.9 & 52.0 & 55.2 & 60.8 & 65.8 & 60.9 \\
\hline & 116.3 & 113.6 & 108.0 & 98.0 & 88.3 & 76.0 & 74.0 & 85.0 & 90.7 & 102.2 & 113.5 & 114.2 & 116.3 \\
\hline $\mathrm{Ab}$ & 45.1 & 46.4 & 44.8 & 39.6 & 36.9 & 32.5 & 32.0 & 32.3 & 32.7 & 36.0 & 40.8 & 43.0 & 32. \\
\hline Mear & 11.1 & 10.1 & 6.0 & 0.8 & 0.0 & 0.0 & 0.0 & 0.0 & 0.0 & 1.6 & 5.1 & 8.8 & 43.5 \\
\hline days under & & & & & & & & & & & & & \\
\hline $\begin{array}{r}40 \\
\text { Kalgno }\end{array}$ & 0.0 & 0.0 & 0.0 & 0.0 & 0.6 & 2.8 & 5.6 & 3.4 & 1.6 & 0.4 & 0.0 & 0.0 & 14.4 \\
\hline & 78.8 & 77.6 & 73.0 & 66.4 & 58.8 & 53.6 & 52.0 & 54.8 & 59.9 & 65.2 & 72.3 & 77.4 & 65.8 \\
\hline $\mathrm{H}$ & 83.1 & 84.3 & 77.4 & 71.6 & 61.6 & 56.5 & 54.3 & 57.7 & 63.8 & 71.2 & 77.8 & 81.7 & 67.7 \\
\hline & 72.2 & 73.8 & $|69.8|$ & 60.5 & 55.0 & 49.4 & 49.5 & 51.5 & 55.8 & 61.2 & 68.0 & 71.0 & 64.2 \\
\hline & 114.4 & $|115.0|$ & 105.0 & 101.4 & 92.0 & 76.8 & 80.0 & 87.0 & ) 95.0 & 101.0 & 110.2 & 113.0 & 115.0 \\
\hline Abso & 47.1 & 48.2 & 43.4 & 37.0 & 34.5 & 32.5 & 31.4 & 32.1 & 32.4 & 38.2 & 38.2 & 47.0 & 31.4 \\
\hline Mean No. & 19.8 & 15.6 & 110.2 & 3.2 & 0.0 & 0.0 & 0.0 & 0.0 & 0.6 & 3.0 & 10.6 & 18.4 & 81. \\
\hline $\begin{array}{r}\text { Mean No. of nights under } \\
40 \ldots \ldots \ldots \ldots \ldots \ldots \ldots\end{array}$ & 0.0 & 0.0 & 0.0 & 0.3 & 2.8 & 6.5 & 11.0 & 7.0 & 2.7 & 0.6 & 0.0 & 0.0 & 30.9 \\
\hline
\end{tabular}

* Supplied by the Commonwealth Bureau of Meteorology, Central Bureeu, Melbourne. 
The number of days during which the shade temperature may reach or exceed $90^{\circ} \mathrm{F}$. in the central portion of Australia may be very considerable (table 7). For example, in the northern part of Western Australia the maximum shade temperature sometimes exceeds $90^{\circ}$ for days or weeks at a time. At William Creek, South Australia, there are, on the average, 114 days in each year when the thermometer registers $90^{\circ}$ or over. When it is recalled that the relative humidity of the air is a function of the temperature, the significance of such long-continued high temperatures for plant growth, more especially in the dry interior, is apparent.

The daily range in the temperature of the air is especially striking in regions where the rainfall is relatively small. Thus in 20 stations in Western Australia and South Australia, whose average precipitation is 8.5 inches, the average daily range of temperature is $37^{\circ} \mathrm{F}$.

Winds.

The action of air currents, both directly and indirectly, upon plants and their environment is of the greatest importance, especially in dry regions. One of the pronounced characteristics of such regions is the prevalence of winds. With little vegetation to impede their way, they are nearly always blowing. During the seasons of rains this is of comparatively little moment to plants, but with the return of dry conditions, particularly during the summer, the winds operate to increase the drought in a marked degree; and even in situations more or less remote from the dry interior the ill effects of the "desert" winds can frequently be seen in the withering of vegetation of all kinds. Thus, in southern South Australia, distant from the dry interior over 250 miles, such winds are experienced occasionally and sometimes are disastrous.

Evidences of wind action are not wanting in other directions. Crescentic-shaped dunes near Oodnadatta, the surfaces of which bear ripple marks, and the moving of fine earth in other places, as at Copley, where fences are buried beneath it, are further indications that the winds are active as well as forceful. The flattening of the "gibbers," which make up the desert pavement characteristic of large areas in the central portion of the continent, may also be an indirect result of wind action. The pavement itself is the result of the removal by the wind of the finer soil particles, and, in fact, it is generally recognized as probable that the wind is a very important agent of erosion in the dry nterior, as eridenced in a great variety of ways (Jutson, 1914:142).

\section{Subterranean Environment.}

The leading habitats of the desertic-semiarid regions are apparently few in number. They are characterized and may be distinguished by their physical nature and chemical content, as well as by their physiographical relations. Thus, there are salt spots, salt plains, and salt slopes in which the soil, often of rather fine structure, carries an excess of salts. Such saline areas are often, but apparently not always, 
associated with poor surface drainage. These areas are so numerous and may be so extensive that they constitute a very important portion of the habitats of the interior. The non-saline habitats are to be distinguished from one another in part by physical and chemical composition and in part by their physiographical relations. The leading differences between them, at least from a biological point of view, rest mainly on differences in their water-content and (probably also associated with this) on their relative temperatures. Thus there are stream-ways and flood-plains and often terraces, plains of several levels. The first two are subject to occasional flooding, but the latter may or may not receive water by seepage from still higher ground. Other plains may occupy the highest elevations and thus may have water relations quite different from those of the plains last mentioned. The plains may, or may not, be protected against wind erosion by a covering of coarse stones, "gibbers." There are also hills and low mountains and the slopes of these. Of the hills, the moving or stationary dunes constitute important features of the physiography of the dry interior. Between the sandy ridges there are often flat "clay-pans" which have interesting features of their own. Inasmuch as the species to be found in these habitats are often, possibly largely, characteristic of them, the subaerial environment constitutes a very important factor in the environment as a whole.

The subaerial environment of plants thus has interesting connection with surface geology and its history would be that of physiography. Without entering into a discussion of this phase of the matter, however, it will be instructive to note certain characteristics of the dynamics of the general subject. Thus, Howchin and Gregory (1909:103) point out:

"An inland basin, like that of Lake Eyre, can not get rid of its worn-down material, such as occurs when the drainage of the country flows into the sea, whilst from a deficiency of moisture vegetation is scarce and the soil is but loosely held together. From this cause the soil and sand are constantly on the move, and with the ever accumulating products of waste, the highesi hills are gradually covered by drift, and the country is ultimately buried under its own ruins."

But the region of the sandhills is not confined to such a depressed area as the great central basin. Thus D. W. Carnegie (1898:178) describes in a very vivid way a sand plain-sandhill region in central Western Australia, nearly 200 miles across in a straight line. Here the general level of the country is considerably above sea-level, but the drainage is inland, or at any rate not directly to the sea, and it can possibly be described as being undeveloped. Without going into the subject much further, another region can be mentioned having an accumulation of detritus (and sand is here especially in mind), where the drainage is not well defined. This is the Ooldea sandhill region. Here are sand ridges of prominence which alternate with narrow flats over a region about 50 miles wide. Apparently the rains are absorbed 
where they fall, as there are no appearances of washing and the main instrument of detrital transportation is the wind, but owing to the fairly abundant vegetation, as will be described below, the moving of the sand, except where the vegetation has been disturbed, is not an important matter.

A notable class of plant habitats is that associated with an excessive amount of salts of whatever kind in the soils. The immediate occasion of the accumulation of the salts is also in part inadequate drainage, but coupled with this are high evaporation and small rainfall.

Beds of gypsum, hydrous calcium sulphate, and of travertine, or desert limestone, calcium carbonate, are frequently to be found in the dry regions. In certain regions outside of Australia, at least, travertine is an important feature of the environment of plants in that it is not easily penetrable by water and constitutes a fairly dry hardpan as a subsoil. By travertine is meant "a deposit of carbonate of lime, laid down on the surface of the ground by evaporating water containing the substance in solution" (Jutson, 1914:228). In many places the travertine is covered by soil and thus constitutes a subsoil. In appearance the travertine strongly resembles the "caliche" of the more arid portions of the United States, and is probably the same substance. The exact soil horizon where the limestone is formed is in dispute (Livingston, 1906:8). In place of its being deposited on the surface of the soil it may be deposited at the evaporating surface, which, in such an arid country as southern Arizona, at least, probably lies somewhat below that of the soil itself.

The nature of the soil is another important factor of the subaerial environment. It is dependent on the nature of the underlying rocks from which the soil was derived by various geologic agencies. As an important feature of the environment of plants it is not confined to regions of small rainfall, but is to be found in the more moist regions as well. Thus Osborn (1914:113) observes in the vegetation of the Mount Lofty Ranges near Adelaide that-

"The second range of foothills, rising about 800 feet to a plateau, presents several markedly distinct types of vegetation which appear to be correlated with the geological formation. The slate hills are covered with grassland and scattered 'gums,' having a parklike appearance. The absence of undergrowth and the maintenance of a sward may be partly due to grazing, but all the difference observable can not be attributed to this cause. Grass is almost entirely absent from the quartzite hills, which are covered by a scrub of many species of shrubby plants."

Jutson (1914:58), speaking of the vegetation of the central or saltlake division of Western Australia, which is arid or semi-arid, says:

"[It is] divided into two main groups, viz: that growing on the basic and that on the granitic rocks; the former being stronger and of a more varied character and the latter often or mainly of a stunted and monotonous type, except that in its annuals or small shrubs there is often both variety and beauty." 


\section{Temperature, Moisture, and Aeration Conditions of the Soll.}

The course of the moisture, aeration, and temperature conditions of the soil are of very great biolgical importance, but, unfortunately, so far as Australia is concerned, only meager data are to be had respecting them. From studies made elsewhere (which are also few) something of their relation to the general problems with which this study in part deals may be drawn; and the interest here lies mainly in the results touching the soils of regions having a small rainfall. As is well known, the three conditions above mentioned are intimately related and it may be remarked that in consequence a modification of one brings changes in the rest. It is also possibly true that, as to the moisture of the soil and its temperature, the maximum of variability finds its apex in dry climates.

The moisture conditions of the soil are dependent on a great variety of factors, among which may be mentioned the amount of rainfall, the physical nature of the soil, atmospheric conditions relative to evaporation, and the plant cover.

The amount of water which a given soil is capable of holding is related to the physical nature of the soil and according to Briggs and Shantz (1912:31) varies from 23.2 to 69.5 per cent of the dry weight of the soil. The smaller amount is that retained in coarse sand and the larger amount is that retained in clay loam, in both instances in opposition to the force of gravity when free water drainage is provided. Not all of the water of such saturated soils, however, is available for the use of plants. Thus the same authors (1911:217) show that, as concerned the species experimented with, the amount of water possible of absorption previous to wilting varied with the character of the soil, but was considerably less than the maximum water-content of the soil. Thus, in fine sand the plant used, Kubanka wheat, absorbed 97.01 per cent; in fine sandy loam it absorbed 90.34 per cent; in clay loam it absorbed 83.7 per cent of the water held by these soils when in a good state of tilth. At the time of wilting, therefore, there is in the soil a certain water-residue which varies with the nature of the soil.

It would be of interest to know for how long a period, in dry central Australia especially, there is sufficient water in the soils for the use of plants. In Southern Arizona some attention has been paid to this phase of the problem. At Tucson, for example, Livingston (1906:72) has found that at a depth approximating 0.5 meter there is possibly always sufficient moisture for absorption by roots. At least the upper soils, on the other hand, are air-dry in the arid foresummer, when they may contain not over 6.5 per cent of their dry weight of water (Shreve, 1914:21). The soil referred to is a fine, brown clay and, from the work of Briggs and Shantz, it would not be expected that the plants could extract from it more than 85 to 90 per cent of its water-content, leaving a non-available moisture content of 10 to 15 per cent. Therefore, the 
amount of moisture in the soil reported on by Shreve could be considerably below that available for plants. Accordingly the arid foresummer in southern Arizona constitutes very largely a resting season for plants. Since this season comprises about 3 months without rain, it can be concluded that as long, or longer, rainless periods as occur in the dry parts of Australia may operate to bring about a condition of extreme soil dryness and that under such circumstances only in favorable situations, or in favorable soils, or in species which reach to deeply placed soil moisture, or which have a water-balance, can vegetational activities be carried on.

Studies on the relation between the moisture-content of the soil and the condition of permanent wilting of plants indicate that all species wilt at approximately the same moisture-content in the same soil, other conditions being equal. Thus, contrary to previously accepted belief, plants native to dry regions are unable "to reduce the water-content of the soil to a lower point than is reached by other plants at the time of wilting" (Briggs and Shantz, 1912:235).

Although possibly the largest percentage of water escapes from the soil through evaporation from its surface, a very considerable amount is lost by reason of transpiration from the plant shoot. This goes on until the limit of water loss is reached only by the establishment of an equilibrium between air and soil, and the final result is the same as if the air and soil were in direct contact (Briggs and Shantz, 1912:20). Not only does the upper soil layer lose moisture through the plant cover, but the deeper layers as well become dry by the same means. Thus it has been determined (Alway, McDole, and Trumbull, 1919:185) that the moisture of the subsoils may be greatly reduced through the action of deeply rooted plants - that is, whose roots are 5 meters or less in length. Where such deep-rooted perennials are wanting, the subsoil remains moist.

Aeration of the Soll.

The aeration of the soil is an environmental factor of plants of much consequence, although it is measured with difficulty and there appears to be no way of expressing it concretely or exactly. Data regarding this phase of environment, therefore, are largely wanting, but it is known in a general way that the soils of the dry regions are, as a whole, well aerated. This follows from the known conditions directly affecting air-movements in soils. Among these the following may be mentioned: Size of the soil grains; compactness of the soil; amount of moisture in the soil; winds and differences in barometric pressure; temperature of the air and of the soil itself; the plant cover.

The composition of the soil is also an important feature in its aeration. In the upper soil layers the atmosphere of the soil usually has about the same composition (except possibly as to moisture-content) as the atmosphere immediately above it. Under conditions of re- 
stricted movement of the air within it, however, it contains less oxygen, but a greater percentage of nitrogen and carbon dioxide. Where such conditions obtain, molecular and not molar gas-movement takes place, gaseous exchange is relatively slow, and soil aeration is least favorable for aerobic organisms. So far as the soils of arid regions are concerned, possibly the most usual cause of poor aeration, in both meanings as above presented, lies in the puddling following rains. Under such conditions the surface is compacted, the soil spaces are filled with water, and mass air-movement ceases. Where this is accompanied by relatively high soil-temperatures the amount of oxygen in the soil atmosphere rapidly decreases and that of carbon dioxide rapidly increases, following the respirational activities of soil organisms of all kinds. There follow differential reactions by which the course of development may be and in certain species certainly is determined. Under extreme conditions of poor aeration such may become a factor limiting the survival of a species in a given habitat.

\section{Temperature of the SolL.}

Few data on the temperature of the soil, particularly as to the more arid regions of Australia, are to be had. However, the general features of the course of the soil-temperature in arid regions are fairly well known. The temperature of the soil varies with a variation in the physical character of the soil, with its moisture-content, and with the depth. Possibly no environmental factor is of greater importance to plant life than this one.

Observations on the temperature of the soil, made at the Desert Laboratory (Cannon, 1911:20), will illustrate the course of the temperature of the soil in a semi-arid climate. The records referred to relate to the temperature taken at two depths, 15 and $30 \mathrm{~cm}$., by means of thermographs. At the lesser depth the daily variation in temperature is about $8^{\circ}$ to $12^{\circ} \mathrm{F}$. and the maximum annual variation is about $69^{\circ} \mathrm{F}$. The period of maximum temperature coincides with that of the highest summer temperature and immediately precedes the rains of that season. With the coming of the rains of summer the soil-temperature immediately falls and it continues to drop gradually until somewhat past midwinter, when the upward movement begins. The rise is gradual until the last of March, when it is somewhat accelerated, and by May the temperature of the soil is nearly that of midsummer.

There are, therefore, approximately 3 months each year, the arid foresummer, in which high soil-temperatures occur at a depth of $15 \mathrm{~cm}$. The maximum temperature, depth $15 \mathrm{~cm}$., observed was $105^{\circ} \mathrm{F}$. $\left(40.56^{\circ} \mathrm{C}\right.$.) and the minimum temperature at that depth was found to be $34^{\circ} \mathrm{F}$. $\left(1.11^{\circ} \mathrm{C}\right.$.). The temperatures of the soil at a depth of $30 \mathrm{~cm}$. have many features characteristically different from those of the lesser depth. Thus the daily range in temperature is $2^{\circ}$ to $4^{\circ} \mathrm{F}$. and the annual variation is about $30^{\circ} \mathrm{F}$. The mavimum temperature 
recorded for $30 \mathrm{~cm}$. depth was $99^{\circ} \mathrm{F}$. $\left(37.22^{\circ}\right.$ C. $)$ and the minimum was $44^{\circ} \mathrm{F}$. $\left(6.67^{\circ} \mathrm{C}\right.$.). The yearly course of the soil-temperatures for this depth is as follows: Beginning with high temperatures of late summer, just before the rains, the temperature drops with the rains and continues the downward movement until March, when a fairly rapid rise begins and persists until the rains of midsummer.

Additional records of $60 \mathrm{~cm}$. and $120 \mathrm{~cm}$. depths, unpublished, show noteworthy features, some of which are as follows: In neither case is there a daily variation determinable by the apparatus employed. In both of the greater depths the maximum temperatures are attained (as at the two lesser depths) just before the rains of midsumm :r. At a depth of $60 \mathrm{~cm}$. the maximum temperature observed was $89^{\circ} \mathrm{F}$. $\left(31.67^{\circ}\right.$ C. $)$ and at a depth of $120 \mathrm{~cm}$. the maximum was $79^{\circ} \mathrm{F}$. $\left(26.11^{\circ}\right.$ C.). The minimum temperature at a depth of $120 \mathrm{~cm}$. was $56^{\circ} \mathrm{F}$. $\left(13.33^{\circ} \mathrm{C}\right.$.), and the annual range was observed to be $24^{\circ} \mathrm{F}$. The course of the temperature at this depth following the rains of summer is downward until late in winter, when it gradually rises until midsummer. Thus the quick temperature rise in spring characteristic of the soil at a depth of $15 \mathrm{~cm}$. does not occur at the greater depths.

The soil of which the temperature at a depth of $15 \mathrm{~cm}$. and $30 \mathrm{~cm}$. was reported on in the preceding paragraph is an adobe clay, and that of which the temperature at greater depths was characterized

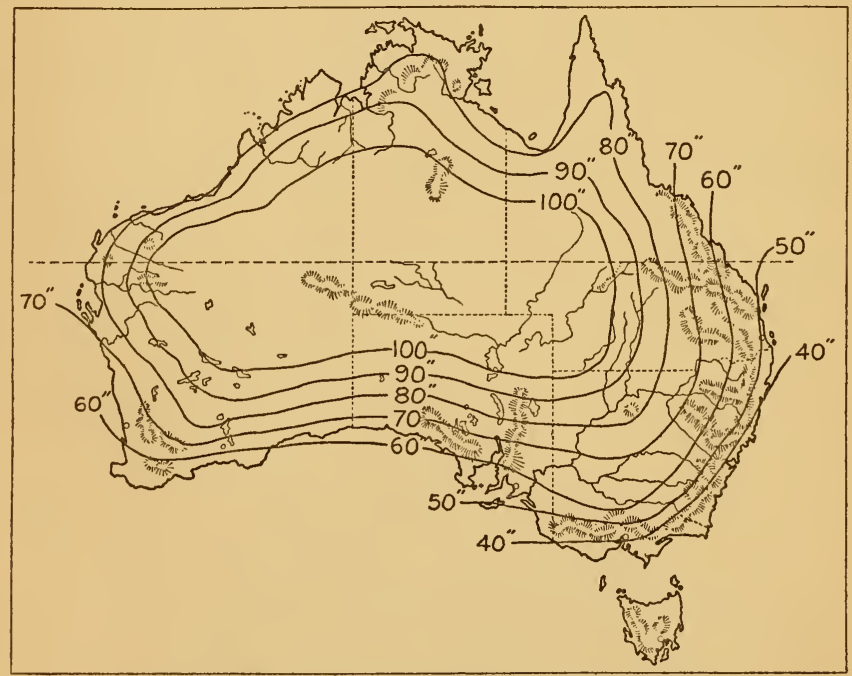

Fra. 8a.-Mean annual evaporation in Australia, after Hunt. 
above was of clay with an admixture of small stones. Soils of other compositions, especially of other physical properties, would give other results. Thus, Hilgard (1906:306), quoting Wollny, states that different soils have summer and winter temperature properties as follows: In summer the sandy soils are warmest, with humous, lime, and loam soils following in the order named. In winter the following order in this regard obtains: humous, lime, loam, and sandy soils. Sandy soils, at least the superficial layers, in summer and in the desert, become intensely hot, according to Hilgard, but at the same time they allow the existence of moisture at a depth of 10 to 12 inches below the surface. Clay soils in the same regions, "being usually in a compacted condition, will show a lower surface temperature and will be warmer and drier at a depth at which sand will still retain abundant moisture and be comparatively cool."

Certain additional features concerning the temperature of the soil should be mentioned. It should be said that the position of the surface relatively to the incident heat rays is of some importance. Thus, as is well known, the sun of winter is less effective than that of summer, and slopes may be warmer or colder, depending on their relation to the direction of the rays of heat impinging their surfaces. Only surfaces lying at an angle of $90^{\circ}$ to the incident rays receive the maximum heat. When the angle is $30^{\circ}$ the amount of heat is about half the maximum, and it rapidly falls with sharper angles (Cannon, $1915^{3}: 213$ ), so that at $15^{\circ}$ from the incident rays it is only about 8.5 per cent of the maximum.

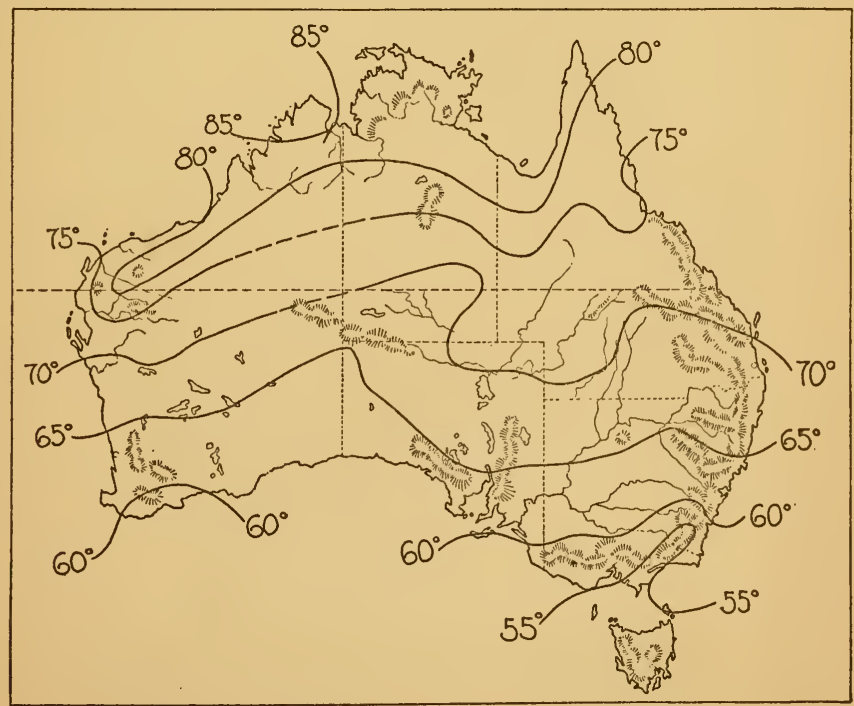

FIG. 8b.-Average yearly temperature of Australia, after Hunt. 
In the preceding summary of temperature differences characteristic of different depths of soil, actual temperatures only were considered; but another point of view, which is instructive, can be held by a summation or integration of the temperatures, month by month, for different depths. Reference is here made to a depth of $15 \mathrm{~cm}$. and $30 \mathrm{~cm}$. and, in addition, that of 2.6 meters is included for comparison. As a whole, it appears that there is a greater amount of heat at $30 \mathrm{~cm}$. than at $15 \mathrm{~cm}$., although the latter has the higher maximum. And it appears that the rains of summer cause a sharp fall in the total heat, but that in the rainless early autumn the total, if not the monthly maximum, temperatures recover and the final drop in heat comes only with mid-autumn. The relative amount of heat at a depth of $15 \mathrm{~cm}$. and at a depth of $30 \mathrm{~cm}$. is surprisingly close. It is only with considerably greater depth that a marked falling off in the total heat is to be found. Finally, it appears that the total amount of heat is greatest during January at a depth of 2.6 meters.

It will be noted that the soil depths above used in the studies on temperature were relatively great. Higher temperatures are known to occur at less depths. Thus, Coville and MacDougal (1903:41) report a temperature of $111^{\circ} \mathrm{F} .\left(43.89^{\circ} \mathrm{C}\right.$.) in volcanic sand and alluvial deposit at a depth of $5 \mathrm{~cm}$. and cite Toumey to the effect that "the temperature of the soil at the depth of one inch near Tucson reaches the temperature of $113^{\circ} \mathrm{F}$. $\left(45.0^{\circ} \mathrm{C}\right.$.) with a mean average of $104.9^{\circ} \mathrm{F}$.

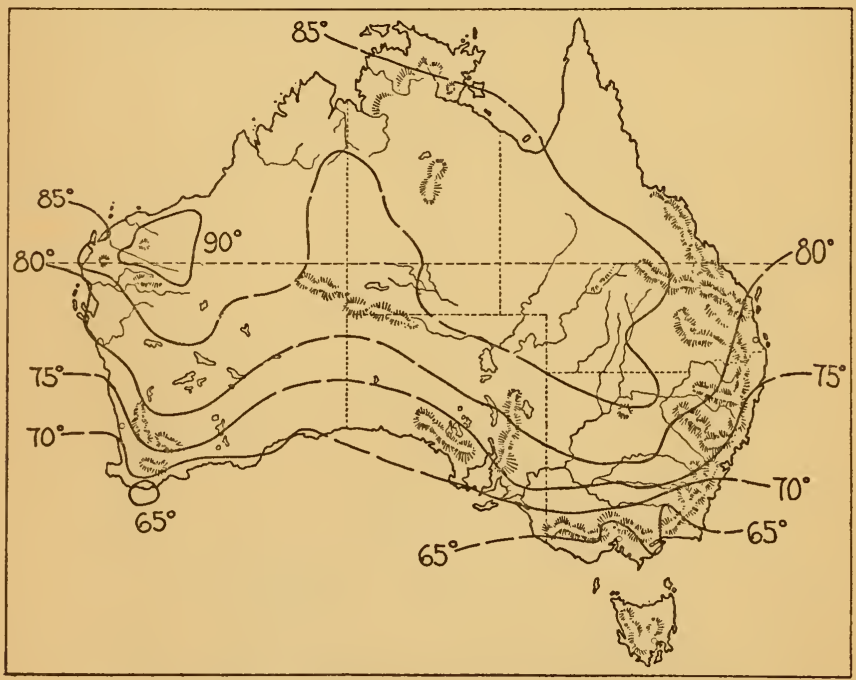

Frg. $9 a .-$ Mean temperature of Australis for January, after Hunt. 
$\left(40.5^{\circ}\right.$ C.) for the entire month of July." Even higher temperatures of superficial soils have been reported (Coville and MacDougal, $q . v .$, p. 41). Therefore, at one and the same moment the roots of species of deeply penetrating root-habit may, near Tucson, be subject to a temperature stress of $33.1^{\circ} \mathrm{F}$. $\left(18.3^{\circ} \mathrm{C}\right.$.) or over, or more than the total maximum yearly variation at a depth of $30 \mathrm{~cm}$.

Owing to the large number of factors which determine the temperature of the soil, it is impossible, in the absence of actual temperaturemeasurements, to satisfactorily adjudge this important feature of the physical environment of plants. Hann (1903:43) states that the daily variations in temperature hardly extend one meter into the ground, and that one observation daily at greater depths suffices to give good means. Conversely, all things being equal, it should be possible to roughly evaluate the mean annual temperature of average soils at a depth of one meter from the air means of the latitude. At the middle and higher latitudes, however, Hann states that the soil at a depth of one meter has an annual mean about $1^{\circ} \mathrm{C}$. above that of the air. Taking the annual average temperature of the air for Australian regions along $135^{\circ}$ east longitude, as given by Taylor $\left(1918^{2}: 4\right)$, we have, therefore, an estimate of the mean annual temperatures of the soil at a depth of one meter and at different latitudes. These are given in table 8, adapted from Taylor. It will be seen that at the depth given and

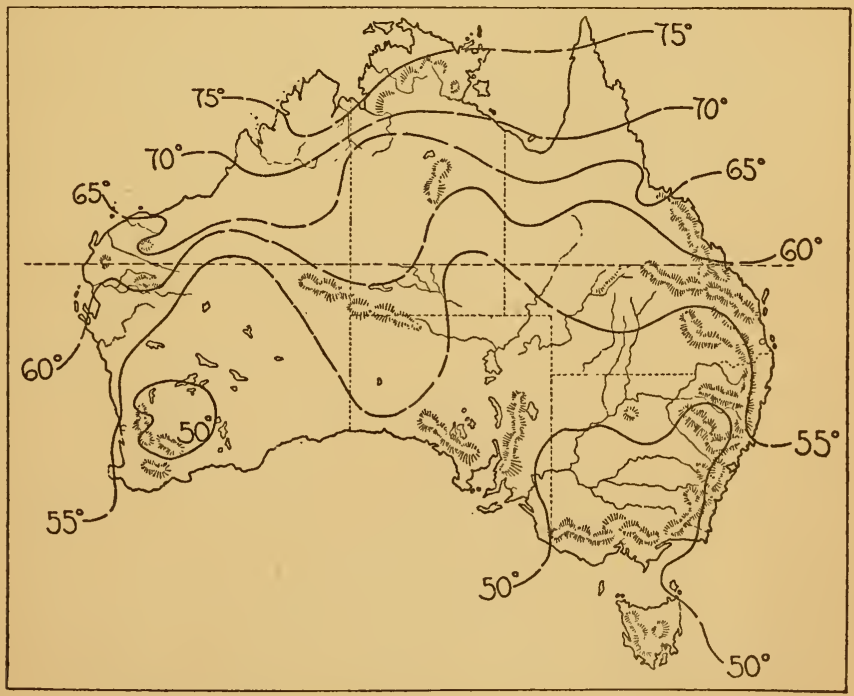

Fro. 9b.-Mean temperature of Australia for July, after Hunt. 
between the extreme north and extreme south of the continent of Australia there is a difference of approximately $27^{\circ} \mathrm{F}$. in the mean annual temperature of the soil.

It is of interest to note that the mean air-temperatures in the desert are higher at parallel latitudes than those given by Taylor for longitude $135^{\circ}$, and probably also the mean temperature of the soil at a depth of 3 feet is higher in the desert. Thus, at William Creek, $28^{\circ} 55^{\prime}$ south latitude, the yearly mean temperature is $68.6^{\circ} \mathrm{F}$. $\left(20.33^{\circ} \mathrm{C}\right.$.), which is $2.6^{\circ}$ higher than at latitude $30^{\circ}$ along the longitude farther east, as given by Taylor. The summer mean temperature of the air and of the soil at William Creek also is quite as high as at latitude $10^{\circ}$, and the winter mean is quite as low; in fact, it is somewhat lower than the mean in the southern extremity of the continent. Thus, at William Creek the course of the mean air-temperature throughout the year, and probably also of the soil at a depth of one meter, is continental in its range.

Table 8 shows the estimated mean annual soil-temperatures, depth one meter, at latitudes given and in regions along $135^{\circ}$ east longitude.

TABLE 8.

\begin{tabular}{|c|c|}
\hline Lat. S. & Soil temp. \\
\hline Tropic: & ${ }^{\circ} F$. \\
10 & 82 \\
15 & 81 \\
20 & 76 \\
Temperate: & 70 \\
25 & 66 \\
30 & 61 \\
35 & 55 \\
40 & \\
\hline
\end{tabular}




\section{CERTAIN CHARACTERISTICS OF THE VEGETATION OF DRY REGIONS.}

In external and internal morphology, as well as in many physiological processes, the regetation of regions having a small rainfall is different from that of the humid regions. For instance, the shoot may be greatly reduced both as to size and surface. The constituent members of the shoot may assume fairly vertical positions. The foliage may be largely restricted to the ends of the branches, from which may arise a canopy-form of shoot. The leaves may be wanting or they may be replaced by phyllodia. Succulency may be found in leaf, shoot, and root, or in any of these. Other modifications include the rolling of the leaves of grasses, greatly elongated type of leaves, or phyllodia, and in some forms dissected leaves in which the leaflets or lobes may be considered the physiological equivalent of leaves. In many species the shoots are provided with trichomes of various kinds, which serve as a protection against rapid loss of water from the surface. The trichomes may protect indirectly through the secretion of resinous substances, which coat the surface, especially of young leaves or shoots (Collins, 1918: 255).

The roots of xerophytes are as a rule deeply penetrating, but this is not without exceptions. Many forms with water-storage capacity, for example, have roots which lie close to the surface of the ground (Cannon, 1911). Also, perennials may have roots of a dual habit in that some are superficially placed, and some may penetrate deeply.

The leaves (or their equivalent) of xerophytes are leathery in texture. An examination of their structure shows certain characteristic features, among which may be mentioned the following: The outer wall of the epidermal cells may be heavy and heavily cutinized and sclerenchyma is well developed. There is usually found palisade tissue and few intercellular spaces. The stomata are protected in various ways, as by being placed at the bottom of tubes, in which case the walls of the tubes may be cutinized. Storage cells for water, which in times of need yield water slowly to the adjacent cells, are often found. In large, fleshy species, where the water-storage tissue is well developed, the stored water may be sufficient to enable the plant to live for a period exceeding 73 months in a dry atmosphere and without absorbing additional water (MacDougal, Long, and Brown, 1915:290).

As would be expected from the specialization of the structures of xerophytes, as well as from the leading features of their morphology, the physiological characteristics of the plants of the desert-arid regions have many points of interest. These are largely associated with the water relations of the plants; thus the effects of dryness have been followed in many directions. The growth-rate is less at midday, when the rate of transpiration is high and, relatively speaking, the rate of water absorption by the plant is low (MacDougal, 1918:59). The progressive desiccation of the soil and of the tissues in Opuntia versicolor 
is accompanied by a change in the "relative transpiration," or transpiration power (relation between rate of transpiration and rate of evaporation). Under dry conditions the $t / e$ ratio is greater by day, but under moist conditions it is greater by night (Shreve, E. B., 1915:79). The fluids of desert plants have a high concentration, as determined by Fitting (1911:209), Lawrence, Gortner, and Harris (1916:1). The concentration of the juices varies in relation to local environmental conditions. It is least in the arroyos and greatest in the salt spots. For example, an average of eight determinations of the density of the juices of plants from the latter habitat gave 37.1 atmospheres. Table 9 summarizes these results.

TABLE 9.-Osmotic pressure, in atmospheres, of various grouth-forms in five habitats of the Tucson region (Harris, 1915:81).

\begin{tabular}{|c|c|c|c|c|c|}
\hline Growth-forms. & Arroyos. & Canyons. & $\begin{array}{c}\text { Rocky } \\
\text { slopes. }\end{array}$ & Bajadas. & Salt spots. \\
\hline Trees and shrubs......... & 17.7 & 22.4 & 22.0 & 34.7 & 47.9 \\
Dwarf shrubs and twiners. & 16.6 & 21.0 & 21.1 & 23.9 & 34.2 \\
Perennial herbs.......... & 13.0 & 14.4 & 16.8 & 19.7 & $\ldots \ldots$. \\
Winter annuals.......... & 12.9 & 13.0 & 15.3 & 21.1 & 23.6 \\
\hline
\end{tabular}

Richards (1918:64) finds that a certain species is more or less succulent when growing under dry conditions, whereas the typical forms, under moist conditions, have thin leaves. In every instance the more succulent form developed less acid than the form less succulent.

The dryness of the atmosphere works immediately to influence the formation of a greater amount of cellulose and a lesser amount of starch (MacDougal and Spoehr, 1918 ${ }^{1}: 247$ ). Thus the polysaccharides are converted into anhydrides or wall material under conditions of aridity, or in succulent species, polysaccharides are converted into pentosans or mucilages. These changes, particularly the last, are of great physiological importance to the species, inasmuch as the "imbibition" capacity of the polysaccharides is small. Their transformation from this form into that of the pentosans gives the increased capacity (of imbibition) characteristic of the pentosans, so that without any addition of material to a cell, but simply by the loss of water, a change takes place by which the cell is capable of absorbing and holding vastly greater proportions of water.

Low water-content of certain cacti results in a condition of general reversion of carbohydrates to polysaccharides. The simpler sugars, or monosaccharides, decrease in amount in the plants as the water-content is reduced. With continued low water-content the pentosans increase decidedly (Spoehr, 1918:62).

It would appear, therefore, that dryness of itself may profoundly modify the chemical nature of plants exposed to its influence and it may lead, as indicated above, on the one hand to formation of wall material, 
or on the other to that of material capable of imbibing water in large amounts. Thus a condition of succulence may be induced, and possibly also the formation of mucilage cells frequently found in xerophytes. The presence of heavy cell-walls, and possibly also the condition of spininess characteristic of many plants of dry rezions, may thus, at least in part, find a rational explanation.

The temperatures of the air and of the soil are of very great importance in many physiological processes of xerophytes as well as other types of plants. Certain of the temperature relations may be here mentioned. For example, the critical temperatures for growth are to a degree specific, and on this fact may depend in part the characteristic distribution of the species, its time of vegetative and reproductive activity, and, in certain instances, the type of root-system developed (Cannon, 1914:81, 1914:83, 1915:62, 1915:87, 1915 :211, $\left.1916: 75,1916^{2}: 435,1917: 82\right)$. In evaluating the temperature of the soil as an environmental factor the critical temperatures for growth of any given species must be known, as well as the soil-temperatures at the depth normally attained by the roots. The total expected growth during the growing season with the aid of these data can be easily determined. In this manner also we may learn the relative efficiency of two stations as regards any species, so far as the soil-temperature is concerned; also, the biological significance of a summation of soiltemperatures may be found by the same means (Cannon, 1917:91).

As to the immediate effects of temperature, only a few especially applicable references need be given. The osmotic pressures increase with an increase in temperature and the rate at which dissolved substances diffuse through protoplasm also depends on temperature. The hydrolysis of starch is hastened by higher temperatures up to $45^{\circ}$ to $50^{\circ} \mathrm{C}$. The acid-content is lowered with higher temperatures. The rate of gaseous exchange, in respiration, is nearly proportional to the temperature. The maximum rate occurs at about $40^{\circ} \mathrm{C}$., and the minimum at $10^{\circ}$ to $15^{\circ} \mathrm{C}$. (Palladin, 1917). The carbohydrate equilibrium of Opuntia sp. depends in part on the water-content and in part on the temperature of the plant. An increase in the temperature results in the more rapid using up of the available simple carbohydrates, the monosaccharides (Spoehr, 1917:73). The rate of water absorption in agar and in biocolloids increases in general with a rise in temperature up to maximum swelling of the plates, which occurs near $40^{\circ} \mathrm{C}$. in agar and somewhat higher in the biocolloids (MacDougal, 1918:68).

The position taken in the ground by the roots of certain species has a very definite relation to the aeration conditions of the soil (Cannon, 1918:81) and the distribution of cultivated plants (Howard and Howard, 1915), as well as certain species native to a semi-arid region (Cannon and Free, 1917:178), may also be directly related to the root re- 
action to conditions of poor soil-aeration. The first noticeable effect of oxygen deprivation to the roots of Coleus sp. is the cessation of the absorption of water (Free and Livingston, 1915:60). This is followed by a cessation of growth and ultimate wilting of the shoot.

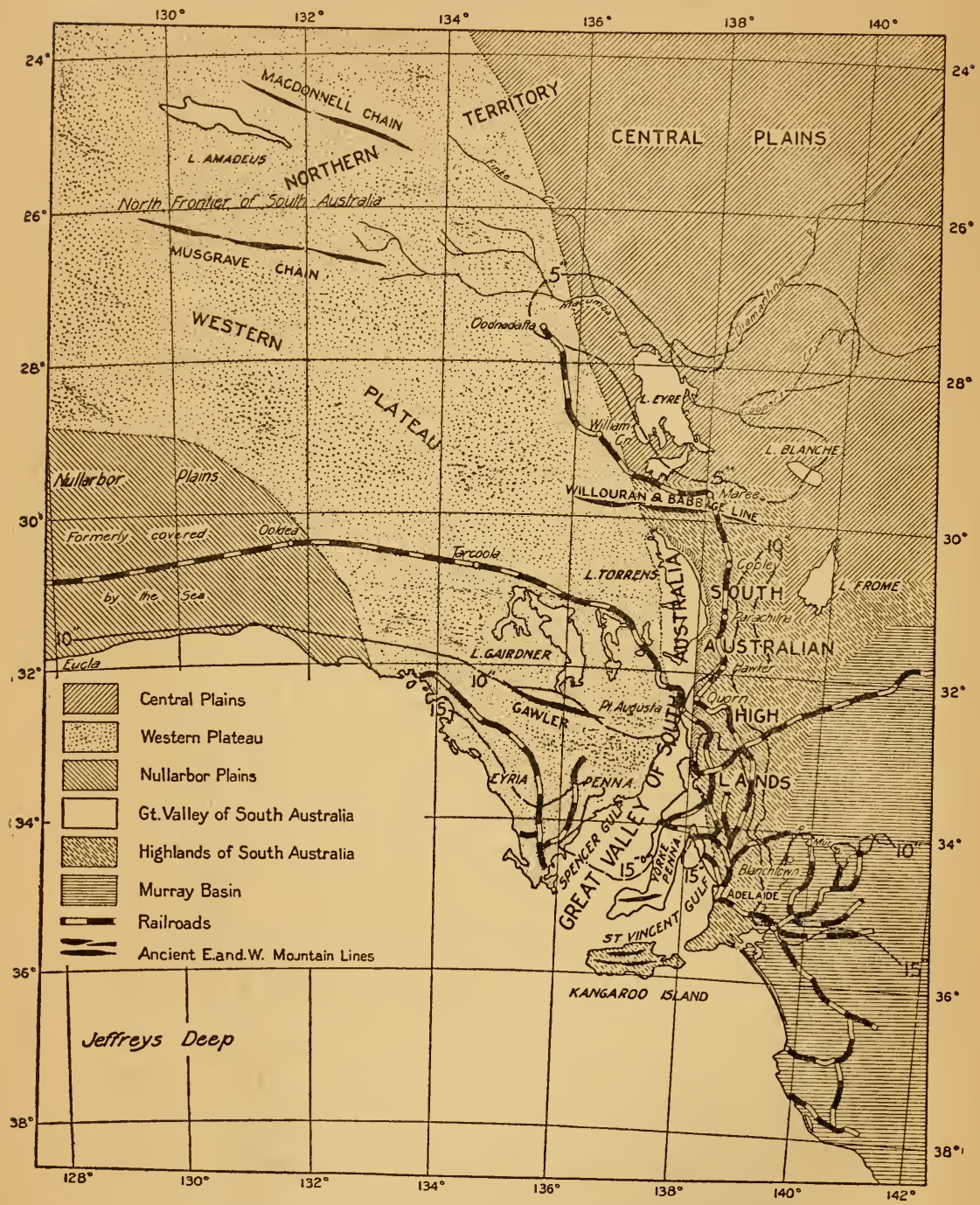

FIG. 10.-Chief physical divisions and geographical plan of South Australia, after Howchin and Gregory, with the 5,10 , and 15 inch isohyets. 


\section{PHYSICAL ENVIRONMENT OF THE VEGETATION OF SOUTH AUSTRALIA.}

\section{PHYSICAL GEOGRAPHY.}

The state of South Australia comprises about 12.8 per cent of the area of Australia. It lies between south latitude $28^{\circ}$ and about $38^{\circ}$, and longitude $129^{\circ}$ and $141^{\circ}$ east from Greenwich. The state, therefore, is wholly included within the temperate zone. In latitude South Australia roughly corresponds with central Chili, Argentina, and southern Africa, and in the northern hemisphere with Algeria, southern Spain, and southern Italy, northern Egypt, Palestine, and the most of Asia Minor, and northern China and Japan. So far as the climate is concerned, as will be shown below, the state probably most nearly resembles southern California, the Mediterranean region, and southern Africa.

South Australia may be fairly well divided into three physiographic general regions, as indicated in figure 10 , page 34 . These may be referred to as the western plateau, the (central and northwestern) highlands, and the lowlands (of the south and east).

The western plateau is an eastern continuation of the great plateau of Western Australia, which embraces about half of the land surface of the continent. So far as concerns the portion of the plateau within the borders of South Australia, it can be divided into three leading physiographic formations, which may be referred to as the Bunda plateau or Nullarbor plains, the Lake Torrens plateau, and the desert sandstone tableland.

The country which lies along the Great Australian Bight, and extending about 150 miles inland, constitutes the region known as the Nullarbor plains, from its supposed treeless character, or Bunda plateau, from the native name for the cliffs. The plateau rises from about 250 feet at the sea to 800 or 1,000 feet along the northernmost portion. It is a limestone plain of Miocene age and constitutes an extension of the older plateau of Western Australia.

The Lake Torrens plateau lies to the west of Lake Torrens, or, more exactly, to the west of the great valley of South Australia. It is of limited extent and is made up in part of flat-topped hills west of Point Augusta, known as the Tent Hills. It attains its greatest width just to the west of Lake Torrens (Howchin and Gregory, 1909:93) and is much older, geologically, than the Nullarbor plains, being of the same age as the Flinders Ranges (Howchin and Gregory, l. c.).

The third tableland, the Desert Sandstone, "once extended over most of central and northern Australia. *** It represents the old land and fresh-water deposits which accumulated after the Cretaceous sea drained off from central Australia." The desert sandstone tableland extends from Copley north and forms the general fea- 
ture of the western side of Lake Eyre. "The regular flat-topped hills represent the old land-levels, fragments of which have been preserved from denudation by hard silicious beds that have formed the protecting cappings for the softer beds beneath" (Howchin and Gregory, l. c.). At present this formation is reduced to a triangle, of which the base abuts against the northern end of the highlands of South Australia (Gregory, 1906:64). On the north it extends apparently beyond the confines of South Australia and on the west it reaches to the eastern end of the Everard Ranges. The desert sandstone belongs to the Upper Cretaceous series. According to Jack (1915:41):

"The series is made up of sandstone, grit, light to grey shale, and a little limestone and, as far as it is possible to judge, has a thickness not exceeding 200 feet. $*_{*}^{*}$ * Subsequent to the elevation of these beds striking hydrochemical metamorphosism has taken place under the joint influence of light, rainfall, and warmth, resulting in very extensive silicification of the surface rocks ${ }^{*}{ }^{*}{ }^{*}$ largely responsible for the very characteristic topography of the Upper Cretaceous areas. ${ }^{*}{ }^{*}{ }^{*}$ The presence of this resistant capping of quartzite, chert, or flint has resulted in the formation of tabletopped hills and tablelands. The wearing away of the soft underlying shales undermines the indurated beds, which break up to form the stony mantle of the 'gibber' plains, and by its presence affords evidence of the former extension of the Upper Cretaceous rocks, even though denudation has proceeded so far as to leave the residual stones resting directly upon the blue shale of the Lower Cretaceous series."

The author goes on to say that the rounded form of the "gibbers" is due to the action of insolation. Many of the stones are highly polished as a result in part from the attrition of dust and sand blown by the wind, and in part from a coating on their surfaces of a glaze caused by the evaporation of siliceous and ferruginous water on the stones. This desert glaze, or varnish, Jack states is a feature common to arid regions. Largely because of the reflection of light from their polished surfaces, but also because of their presence under foot, the gibber plains present difficulties for the traveler. For example, Spencer and Gillen (1912:40) narrate:

"A little vay to the north of Oodnadatta we passed on to gently undulating country, with low-lying, flat-topped hills and remarkable plains covered with small stones. Nothing could possibly be more desolate than these 'gibber fields.' ${ }^{*} *{ }^{*}$ The horizon is shimmering and indistinct and the level ground is covered with a layer of close-set, purple-brown stones, all made smooth and shiny by the constant wearing action of wind-borne sand grains, for, in winter especially, a strong southeast wind often blows all day long."

As these excerpts would indicate, the desert sandstone plateau constitutes, for various reasons, a feature of the landscape of the more arid portion of South Australia that is striking in the extreme.

The mountains and the hill country of South Australia are of two classes, geologically unlike and to a degree constituting separate physio- 
graphic areas. Of these, the more ancient, Archæan, make up the large and relatively high upland area in the extreme northwest portion of the state, where are the Musgrave Ranges and others. Remnants of former extensive mountain ranges, similar ancient rocks, occur south of Oodnadatta, and as isolated hills and low ranges to the west of the great valley of South Australia. Of these, the chief may be said to be constituted by the Gawler Range, and among the isolated hills, those at Tarcoola and Wynbring. In addition, portions of the Flinders Mountains, including parts of Mount Lofty Ranges near Adelaide, belong to the ancient pre-Cambrian mountain system. In the region west of the great valley the elevations of such rocks are for the most part inconsiderable. It is the waste of the ancient granitic rocks, which, according to Howchin (1909:67), has supplied the sand in the region to the north of the Great Bight. The elevation of the ranges referred to as being in the northwestern portion of the state is very considerable, reaching an altitude of 5,200 feet, which is the greatest altitude in South Australia.

But the greatest area of highlands in South Australia is made up of a hilly or mountainous central region which extends from the southern ocean due north to Maree (Hergott Springs), approximately 500 miles. This elevated region may perhaps be regarded as a peneplain which has become much worn down and much dissected by streams. It constitutes one geographical unit. In the northern portions the mountains bear the stamp of an arid climate, but in the south the outlines are rounded from the accumulation of soil and are well covered with vegetation.

Following Howchin, we can for convenience separate the Central Highlands into three groups. Of these, the southernmost is made up very largely of the ranges which together constitute the Mount Lofty system. These attain an extreme altitude of 2,334 feet (Mount Lofty). The middle section is made up of peneplains and rugged hills, the highest of which (Mount Bryan) is 3,065 feet. The general direction of the mountains of the Central Highlands is north-south. They are separated from one another by the undulating plains, peneplains, which, in the middle section, along the line of the railway at least, do not attain a greater altitude than 2,000 feet above the sea (Howchin and Gregory, l. c., 86). The middle section joins the southern end of the Flinders Mountains. Extending as it does north to Maree (Hergott Springs) and east to Lake Fromme, the Flinders Range constitutes by far the largest portion of the Central Highlands. In the region of Port Augusta-Quorn the mountains attain an altitude of 3,174 feet (Mount Remarkable), with Mount Brown and Devil's Peak, near Quorn, slightly less. Mount-Arden, about 10 miles north of Quorn, is one of the lower summits.

On its way north the railway parallels the eastern shore of Lake Tor- 
rens, and for much of the way skirts the western base of the Flinders. As seen from the railway line, the mountains rise fairly abruptly from the plain. This is due, according to Howchin, to faulting connected with the formation of the great central valley of South Australia. Near Beltana the line enters the hills and at Copley (Leigh's Creek) it runs in the valley separating the smaller western range from the main ranges to the east. The highest altitude given by Howchin of the northern Flinders is 3,120 feet (Freeling Heights), and among the prominent elevations is Mount Serle, east of Copley, to which reference will be made later. It has already been mentioned that in the north the Central Highlands assume the rugged appearance characteristic of mountains in an arid land. This implies also the presence of canyons cut deep by water-courses. Such stream-beds are dry, however, a large part of the year.

For the most part the Central Highlands are of lower Paleozoic (Cambrian) age. The exceptions to this have already been referred to. There are occasional structures which are of great interest to the geologist, as, for example, the circumclinal fault known as Wilpena Pound, where a great basin was formed, access to which can be had at one point only, and the glacial "till," supposedly pre-Cambrian, which can be seen at Depot Flat, near Quorn, as well as at other places.

From the present standpoint the leading interest in the highlands of South Australia lies in their effect on the climate. The isohyets and isotherms are pushed considerably northward by the central land elevations and with this, and because of it, an extra-regional distribution of plants occurs by which those of the cooler and more moist south are projected far north, into the midst of a region that is remarkably hot and dry.

The lowlands of South Australia may be said to consist mainly of the basins, great and small, in which the lakes in the northern portion of the state more especially are situated, and, in addition, the region along the course of the Murray River. They are the Lake Eyre Basin, that of Lake Fromme, Lake Torrens, and Lake Gairdner. In addition are the coastal plains, of which the one between Port Augusta and Port Pirie needs only be mentioned. The positions of these basins are given in figure 10.

The Lake Eyre Basin is a part of the great artesian basin of central Australia, which is estimated by Taylor $(1914: 108)$ to have an area of 576,000 square miles. Only a relatively small proportion of the total, however, is in South Australia. The deepest portion of the basin centers in Lake Eyre, the bottom of which is estimated to be 60 feet below the level of the sea. Where the railway crosses the southern extremity of the lake the altitude is 3 feet below the sea. The basin is a closed one, but the evaporation-rate is so great that much of the area which constitutes the lake is dry most of the time, being covered by 
water only at times of flood. In the south arm, however, the lake usually contains salt water. Important streams enter Lake Eyre on the east, west, and north, of which the Barcoo, or Cooper's Creek, is the most important. On the western side is Neales River, near which Oodnadatta is situated, and which is in part a broad and poorly defined drainage channel, which carries water but rarely.

Howchin remarks that the opinion formerly held, that the sea had but lately retired from this vast country, is not correct. Rather at a remote time, the Cretaceous, the sea extended from the north as a great gulf, or sea, and covered most of central Australia. Probably there never was a continuous connection, north to south, between what is now Spencer Gulf and the Gulf of Carpentaria. The lowest portion of the land connection between the two is at present given as being 175 feet above the sea. The depression in the southern portion of the Great Basin is thought to have been brought about through a secondary subsidence affecting this portion only. The desert sandstone, as remarked above, was laid down in Upper Cretaceous time, during a period of elevation when the basin was a fresh-water lake. At this time the rainfall was probably better than now and the climate cooler.

The surface features of the Lake Eyre Basin, and these are representative of the entire region, are of three kinds, according to Howchin and Gregory. These are tablelands, which, as seen in the vicinity of Oodnadatta, are generally of relatively small extent: (1) "buttes" in fact, (2) stony deserts which are constituted by the "gibber" plains, and (3) the sandhills. At Oodnadatta, also, the surface (except the tops of the buttes) is covered by small stones of various sizes and shapes. The "gibbers" are usually flattened, polished, and of a reddish-brown color. From the fact that the stones fit together closely, they are probably important in conserving whatever water may fall by cutting down evaporation from the surface of the soil. Just about Lake Eyre, on all sides, sandhills are plentiful; in general, these constitute an important feature of the surface topography in the northern part of South Australia. The sandhills occur as ridges, usually not of great height, and run in a generally northeast and southwest direction. They are frequently separated by "clay-pans," a quarter of a mile or more in diameter, which hold water for a period after rains. Like the "gibbers," the sand is derived from the eroded desert sandstone. As Howchin points out, owing to there being no opportunity for carrying away the sand, as by water-currents of whatever kind, it remains in the basin, diffting here and there through the action of winds, and "with the ever-accumulating products of waste, the highest hills are gradually covered by drift and the country is ultimately buried under its own ruins" (Howchin and Gregory, 1909:103). 
A striking and characteristic feature of the Lake Eyre Basin as a whole is the fact that it is an important part of the vast artesian basin of Australia, of which approximately one-fifth lies in South Australia. There are numerous "mound" springs on the border of Lake Eyre and many deep borings have been made, some of which yield great quantities of water. The one at Coward Springs, for example, has a daily flow of $1,000,000$ gallons. The water-supply is derived from the western flanks of the mountains of New South Wales and Queensland and the intake is chiefly porous sandstones, probably of different geological ages. These sandstones are covered by great thicknesses of dark-blue shale, sandstones, and impure limestones of Cretaceous age. Thus the subterranean water is far too deep to be of direct benefit to surface plants, if it were always of suitable quality, which is sometimes not the case.

To the southeast of Lake Eyre is situated a chain of lakes, of which Lake Fromme is the largest. These are described by Howchin as being merely extensive flats which are sheets of water after heavy rains and are saline wastes during dry seasons. They are the centers of a relatively restricted drainage area, and no rivers of importance discharge in to them.

Another group of related basins, somewhat larger than those of the Fromme group, lies to the west of Lake Torrens and north of the Gawler Ranges. Of these, the largest is Lake Gairdner. The TransAustralian Railway skirts the northern portion of these basins. Tarcoola is a few miles west of them and Port Augusta is 50 miles, more or less, to the east. Lake Gairdner and the rest of the basins lie at the northeastern side of scattered remains of mountains of Archæan age, from the waste of which the sand of the region may have been derived. The region is relatively very dry. The 10 -inch isohyet which, in passing through the Flinders Mountains, curves rapidly to the north, is here deflected as strongly to the south and includes none of the area.

The northern section of the Flinders Mountains has on the west the central rift-valley of South Australia, which is made up of Lake Torrens on the north and a descending series of flats and lagoons which connects it on the south with Spencer's Gulf. Thus Lake Torrens, which owes its existence to faulting, is in a manner distinct in origin from the other basins. The bold western side of the Flinders Mountains has already been noted. This is the upthrow side of the north-south fault by which the Great Valley of South Australia was formed. This fault, as Howchin states, increases in importance as it goes south and includes Gulfs Spencer and St. Vincent (see also Taylor, 1918:97). The area of depression, therefore, fairly parallels the western side of the entire central mountain system of South Australia.

That the earth's crust in this region is not in equilibrium is further evidenced by the occurrence of earthquakes from time to time center- 
ing along some portion of the rift valley. No important rivers empty into Lake Torrens and what water it holds is derived directly from such rains as fall on its surface. It is well without the 10-inch isohyet, the average rainfall of the basin being probably but little over 6 inches.

Figure 13 (Taylor, $l$. c.) gives concisely the main points in the geological history of the rift valley of the central portion of the state. As Taylor explains, in " $\mathrm{A}$ " is given a hypothetical diagram showing how in former ages there was a well-developed and centrally situated drainage system which led from the Barkly tableland on the north down to Jeffrey's Deep. The general course of the valleys is north and south. The Central Highlands, comprised by the Flinders and adjoining ranges, have not yet been formed. In "B" important alterations are seen to have taken place. The sea has encroached on the land to the south, advancing up the basin of the Murray River. In the meantime, epeirogenic movements have raised an elongated plateau in the south, and this has affected all of the river courses, in places blocking them and bringing about the formation of lakes. We thus see the origin of all of the leading lakes and basins. In " $\mathrm{C}$ " the western portion of the uplift is seen to have slipped in, forming Spencer's Gulf and Gulf St. Vincent. The MacDonnell Ranges (Northern Territory) have arisen and the Lake Eyre Basin has sunk away from the earlier grade. The early river system may possibly date back as far as the Cretaceous, when a vast sea covered the western portion of Queensland. It seems certain that in the early geologic times the rainfall was heavy in central and northern South Australia and in central Australia. Taylor suggests that the heavy rainfall in the past may have been due to the presence of great arms of the sea to the east, such as the Tertiary sea at the mouth of the Murray.

The Murray-Darling lowlands are very extensive. Taylor estimates the area to be an approximate square of about 400 miles on each side. Of these only a small portion is included within the state of South Australia, and it is wholly comprised of the ancient Murray estuary or bay, into which, in earlier geologic times, the Darling and the Murrumbdigee, as well as the Murray, emptied by separate mouths. The ancient estuary is for the most part flat, except an area in the southeast, where there are sandhills only a few feet above the sea. According to Howchin, for example, at the point where the River Murray enters the state, its summer level is but 57 feet above sea-level. At Morgan it is only 5 feet 4 inches, which gives a gradient of the river of only 0.5 inch to the mile. The banks of the river at Blanchtown are approximately 150 feet higher than the level of the stream at low water. As one overlooks the area from the mountains to the west, where the view is very extensive, it is unrelieved by any eminences whatever. This flatness, together with the blueness of the distant mallee forests, gives the impression that one is looking over the sea. 
The most interesting feature of the country is the River Murray. The Murray and its tributaries drain the western slopes of mountainous eastern and central Queensland, New South Wales, and Victoria. In favorable seasons, with its main tributary, the Darling, it can be navigated for 2,000 miles. At Blanchtown at high-water (as in October 1918) the river is approximately 600 feet wide. The vertical variation between the summer level of the river and the winter-flood level is 20 feet or more. In the area considered it does not overflow its banks and it has no direct and immediate effect on the native flora along its shores.

\section{CLIMATE.}

\section{TEMPERATURE.}

South Australia enjoys a mild temperate climate. The lowest temperature recorded up to 1912 was at Mount Barker, $24.3^{\circ} \mathrm{F}$., and the highest recorded shade temperature was $119^{\circ} \mathrm{F}$. at William Creek, in the far north, about midway between Maree (Hergott Springs) and Oodnadatta. The former is near the southern termination of the Central Highlands and the latter is in the Lake Eyre Basin. Except in the more arid districts the seasonal and the diurnal variations are not extreme.

The $65^{\circ} \mathrm{F}$. isotherm enters the state slightly south of the center of the eastern border, curves to the north in crossing the Central Highlands, dips south in the Lake Gairdner Basin, and, taking a northwestern direction, reaches the highlands in the extreme northwestern portion of the state. Here it is again deflected sharply north and leaves the state not far from the northwestern corner. About 64 per cent of the entire area of South Australia is within the $65^{\circ}$ to $75^{\circ} \mathrm{F}$. isotherms.

The really great difference in the apparent amount of heat received by the northern and mainly arid (as contrasted to the southern and mainly humid) portions of the state is further suggested by the number of days in each in which the thermometer registers a shade temperature of $90^{\circ} \mathrm{F}$. or more. At William Creek, for example, there are on the average 114 days in each year when the thermometer registers a temperature of $90^{\circ} \mathrm{F}$. or over, while, on the other hand, at Adelaide, which is by no means the coolest southern station, the number of days in which the thermometer shows this temperature is only 43 in the year. This may not mean, however, that there is a corresponding difference in the amount of heat units actually received between the two stations, since there are nearly three times as many nights, 40 as against 14, during which the thermometer records a temperature of $40^{\circ} \mathrm{F}$. or less at William Creek, as opposed to night temperature at Adelaide. Here again the temperature at Adelaide probably does not represent the extreme condition, but reveals the steadying influence of the Southern Ocean, near which the city is situated. 
The main influences which shape the temperature of South Australia are the latitude, the relation of the state to the balance of the continent and to the Southern Ocean, and the topographical variation of the state itself.

The temperature conditions of the Lake Eyre Basin, of the Flinders Ranges, and of the southern end of the central rift valley will be characterized in connection with descriptions of the flora of these respective regions. In this place it will be necessary only to refer to the temperature of the plateau region of the western portion of the state.

As described in the preceding section, the Western Plateau is a vast region, since it is united to the plateau of Western Australia. The extreme north-south extent is approximately 700 miles. Not much is known exactly in regard to the meteorological conditions of most of the plateau. The reason for this lies in its sparse settlement and in the fact that much of it is hardly more than explored. From the usually meager notes of the rare explorer, however, it is known that in the northern and western portions of the plateau there is a very considerable daily as well as large seasonal variation in temperature.

Howchin and Gregory (1909:145) state that in the inland and central regions the diurnal variation may be as great as $40^{\circ}$ to $50^{\circ} \mathrm{F}$., and that in winter, while the days may be very warm, the cold at night may be sufficiently intense to freeze the contents of a water-bag into a solid mass of ice. The same authors cite the observations made on temperature by the Elder Scientific Exploring Expedition, 1891-92, which crossed the plateau between the Peake and Western Australia borders. In winter during the day the temperature was about $60^{\circ}$ to $80^{\circ} \mathrm{F}$., but at night it dropped to $8^{\circ}$ or $10^{\circ}$ below freezing. White (1915:713), speaking of the northern portion of the plateau, says that just before reaching the foothills of the Musgraves camp was made in a dense thicket- "the night was bitterly cold and everything was frozen hard."

Further south the temperature, especially of summer, is greatly influenced by the Great Bight to the south. In an earlier account of the general temperature conditions of the continent reference has already been made to the drying effects of the desert winds, and it was stated that these effects are to be experienced several hundred miles from the deserts themselves. In the southern portion of the Great Plateau region, however, opposite conditions may also be encountered. For example, at Tarcoola, which is 100 miles or more from the Bight, its influence is frequently met. The summer temperatures at the place may be as high as $118^{\circ} \mathrm{F}$., as unofficially reported, but after a wind from the south sets in the drop in temperature is immediate and considerable. It may be remarked that similarly situated regions of the state also share the cooling effects of the winds from off the southern sea. 


\section{RAINFALL.}

South Australia is the only state of the Commonwealth in which the area receiving 10 inches, or less, of rain is greater than the area which receives more than 10 inches. The ratio of the two is roughly $6: 1$. The 10-inch isohyet runs in a general east-west direction. The 15-inch isohyet lying to the south has a fairly similar course, but the northernmost point attained is at the southern end of the Flinders Mountains, near Mount Remarkable. Between these two isohyets lies "Goyder's line of rainfall," which marks the northern limit for the successful growing of wheat. The pastoral occupations are mainly carried on in the country of intermediate rainfall to the north of "Goyder's line," although sheep in large numbers are raised in the far north. The leading industries of the state can thus be said to be strictly limited and made possible by the amount and the distribution of the rain.

TABLE 10.-Rainfall of 1 inch or more occurring in 24 hours at Oodnadatta, Copley, and Quorn, 1901-1906.

\begin{tabular}{|c|c|c|c|c|c|c|c|c|c|}
\hline \multirow[b]{2}{*}{ Year. } & \multicolumn{3}{|c|}{ Oodnadatta. } & \multicolumn{3}{|c|}{ Copley. } & \multicolumn{3}{|c|}{ Quorn. } \\
\hline & Date. & $\begin{array}{l}\text { Amount } \\
\text { in } \\
\text { inches. }\end{array}$ & $\begin{array}{l}\text { Total } \\
\text { for } \\
\text { year. }\end{array}$ & Date. & $\begin{array}{c}\text { Amount } \\
\text { in } \\
\text { inches. }\end{array}$ & $\begin{array}{l}\text { Total } \\
\text { for } \\
\text { year. }\end{array}$ & Date. & $\begin{array}{c}\text { Amount } \\
\text { in } \\
\text { inches. }\end{array}$ & $\begin{array}{c}\text { Total } \\
\text { for } \\
\text { year. }\end{array}$ \\
\hline \multirow{3}{*}{$\begin{array}{l}1901 \ldots \ldots \\
1902 \ldots \ldots \\
1903 \ldots \ldots\end{array}$} & Feb. 20 & 1.67 & 4.94 & $\begin{array}{l}\text { Feb. } 12 \\
\text { Aug. } 25\end{array}$ & $\begin{array}{l}1.31 \\
1.20\end{array}$ & 6.49 & & none. & 10.14 \\
\hline & & $\begin{array}{l}\text { none. } \\
\text { none. }\end{array}$ & $\begin{array}{l}2.61 \\
5.43\end{array}$ & Nov, 27 & $\begin{array}{r}\text { none. } \\
1.26\end{array}$ & $\begin{array}{r}1.95 \\
11.53\end{array}$ & Sept. 17 & $\begin{array}{r}\text { none. } \\
1.09\end{array}$ & $\begin{array}{r}7.76 \\
18.09\end{array}$ \\
\hline & & & & Dec. 28 & 3.20 & ….... & $\begin{array}{l}\text { Oct. } 17 \\
\text { Oct. } 26\end{array}$ & $\begin{array}{l}1.27 \\
1.43\end{array}$ & \\
\hline $1904 \ldots \ldots$ & $\begin{array}{l}\text { Feb. } 19 \\
\text { Feb. } 26\end{array}$ & $\begin{array}{l}1.82 \\
1.68\end{array}$ & 8.92 & $\ldots \ldots$ & none. & 9.76 & Feb. 19 & 1.84 & 13.09 \\
\hline $1905 .$. & Jan. 28 & 1.26 & 5.69 & & none. & 5.03 & May 8 & 3.10 & 12.82 \\
\hline $1906 \ldots$ & . . . . . & none. & 3.03 & May 23 & 2.89 & 13.00 & June 11 & 1.57 & 18.74 \\
\hline & & & & June 18 & 1.75 & ........ & June 22 & 1.12 & \\
\hline & & & & Sept. 17 & 1.10 & ....... & Sept. 27 & 1.32 & \\
\hline & & & & & & & Nov. 14 & 1.45 & \\
\hline
\end{tabular}

The rainfall of South Australia is periodic. The seasons of rainfall are the best marked in the southern portion. As one progresses northward the distribution through the year is more equable until the far north is reached, when the rainfall conditions typical of the central portion of the continent are met. Thus at Adelaide, which may be used to illustrate the rainfall conditions of the southern districts, about 80 per cent of the rain occurs during the cool season. The average rainfall at Adelaide is 21.06 inches. At Quorn, near the southern end of the Flinders Ranges and nearly midway in the Central Highlands section of the state, the average yearly rainfall is 13.82 inches. Of this, about 57 per cent occurs in the cool season. At Copley, near the northern end of the Flinders and on the western side of the mountains, the amount of rainfall in the cool season, April to August, is about 38 
per cent of the total for the year. The average rainfall at Copley is about 8.7 inches. At Oodnadatta, where the rainfall is 4.85 inches, the percentage falling in the months mentioned is about the same as at Copley.

The periodic rainfall in the southern and central portions of South Australia and the more equable distribution in the north are directly related to the seasonal north-south shifting of the climatic complex.

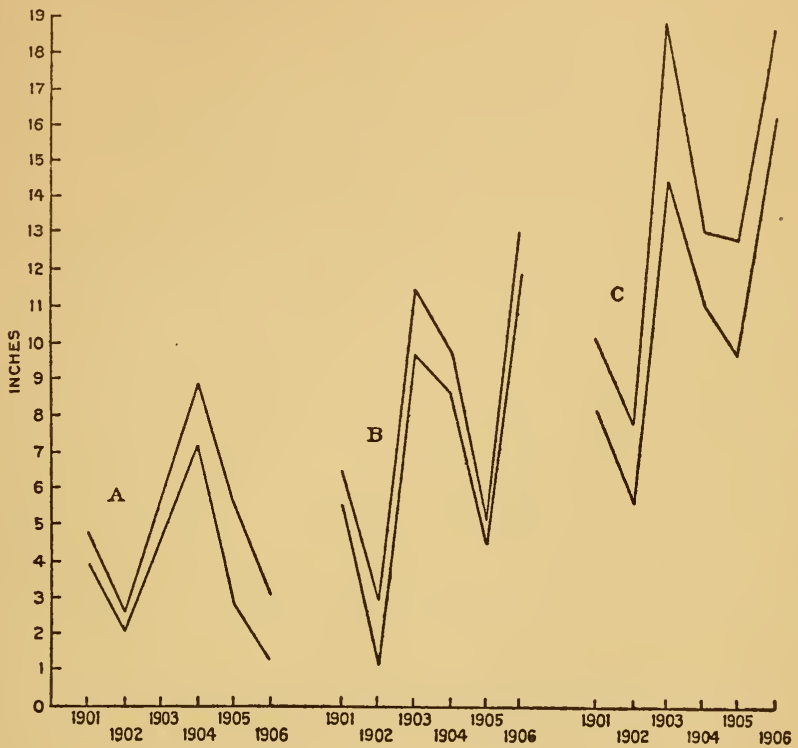

Fie. 11.-Graphs showing the annual (total) and "non-effective" rainfall for 1901-1906 at Oodnadatta (A), Copley (B), and Quorn (c), South Australia, based on records supplied by the Adelaide office of the Commonwealth Bureau of Meteorology.

As Taylor graphically shows (1918: Solar control model), the prevailing line of the center of high pressures in mid-winter coincides nearly with the northern boundary of South Australia, but in midsummer it is far south of the state. The prevailing winds in summer, therefore, are from the east, or southeast, and are drying winds. But at this time occasional lows from the northern part of the continent may extend far to the south, reaching the northern part of South Australia, bringing rain. In winter, however, the center of highs, as before remarked, crosses the extreme north of the state, the belt of westerlies touches the extreme south, and a belt of variabes lies between. The dry easterlies are now far to the north, and rain occurs in 
the south. The storms of winter are cyclonic in character. Areas of low pressure (cyclonic) alternate with areas of high pressure (anticyclonic.) The former are ascending, expanding currents and therefore deposit their moisture; the latter are descending, condensing currents, cold and therefore dry.

From this it will be seen that the rains in the southern portion of South Australia and in the highlands extending north into the center of the state, which project the southern climatic conditions to the north, are periodic and also dependable. But the rains of the northern portion of the state are not regularly controlled by the winter climatic conditions, or those of summer, and hence are not dependable and are scarcely periodic. Further, as indicated in an earlier paragraph, the midstate region has a rainfall of an intermediate character, both as regards the amount and as regards the periodicity.

The lowest rainfall reported in South Australia is at Kanowana, Lake Eyre Basin, where it is 4.33 inches, the average of observations covering a period of 18 years. The rainfall in all of the basins is low, and that of the Murray, although of larger amount than the others, is nevertheless relatively low. This may be because of the proximity of highlands to the west. Lake Eyre is in the midst of the 5-inch isohyet. The basins of Lake Torrens, Lake Gairdner, and Lake Fromme have about 2 or 3 inches more rainfall than that of Lake Eyre.

Over a very considerable area in the drier portions of the state the rainfall is to a very considerable degree uncertain as to amount. This is true both as regards that for the entire year and for separate storms. Thus, it will be shown below that a relatively large percentage of the precipitation in the northern parts of South Australia occurs in amounts too small to directly benefit plants. But, on the other hand, a very large portion of the yearly rainfall sometimes occurs in a single storm. In the latter instance much of the precipitation does not penetrate the ground, but runs off and does not benefit plants directly. In the latter rain-type it is difficult to estimate the proportion which can be said to be effective, since it depends on the nature of the soil, the plant cover, and (not to mention other features) the slant of the surface, as well as the character of the storm itself. For these reasons only the smaller precipitation amounts, as presented in the following section, are deducted from the entire rainfall in order to arrive at the amount of rainfall which can be said to be "effective."

It will be seen in table 10 that about 25 per cent of the yearly rainfall may occur in a single storm, for example that of May 8, 1905, at Quorn. And at Oodnadatta, in 1901, the relative amount was even greater, although the actual precipitation in the single large storm of the year was less. The greatest single rain recorded at the three stations given in the table and for the years referred to was on December 28,1903 , at Copley, when 3.20 inches were reported. 


\section{Effective Rainfall.}

It does not require long experience with the climate of South Australia, particularly with the drier portions of the state, to recognize the probability that not all of the rainfall reported in the official summaries is of direct benefit to the native flora. Also, what may be said to be an effective rainfall, from this point of view, at one period of the year may not be so at another period. And, further, the time relations of successive storms must also be considered.

In order to determine what might be considered a minimum rainfall for the native plants, the actual penetration following rains of known but small amounts was observed and measured on a few occasions. Thus, at Copley, on a morning following a slow rain amounting to 0.21 inch, it was found that the ground was freshly moistened to a depth of 4 to $9 \mathrm{~cm}$. At another time, when a rainfall of 0.27 inch was reported, the soil was found wetted to a depth of 5 to $8.5 \mathrm{~cm}$. The last observations were made 4 hours after the rain had ceased falling.

On the plain near Copley there are numerous diminutive drainage channels, $15 \mathrm{~cm}$. deep, or less. These may form separate systems of considerable extent, or they may be tributary to larger drainage systems. Whichever it might be, it was noticed that in none of the small channels were there pools following a rain of 0.27 inch. The rain penetrated where it fell. At Ooldea, also, after a rainfall amounting to $0.21 \mathrm{inch}$, the soil was found to have been moistened to a depth not exceeding $3.5 \mathrm{~cm}$. In both situations there was a large percentage of sand in the soil.

As will be shown in another place, the depths given would include the horizon within which the roots of many winter annuals are to be found and also the most superficially placed roots of certain of the perennials. Deeply rooted plants of all sorts would not benefit directly by falls of rain of these amounts; and it may be questioned whether in summer such small rains would benefit the annuals or the superficially rooted perennials, owing to the rapid evaporation from the surface of the soil. The foregoing remarks have been made with respect to individual storms.

If separate storms follow one another with little time intervening, it is clear that there would be a progressive moistening of the soil, with the effect that the total depth moistened might be considerable. It is necessary, therefore, to take into account the time which elapses between successive stormy periods. However discouraging for exact statement such considerations, and others that will readily occur, may be, it seems worth while to establish tentatively what may be considered the minimum effective rainfall. And before making the definition it should be pointed out that it concerns the native vegetation and not that of agricultural value, inasmuch as the amount in the latter case would necessarily be greater. Musson (1904:3) states that only 
rains amounting to over "20 points," i. e., $0.20 \mathrm{inch}$, do real good in an agricultural way. With these and other observations in mind, it has been concluded to lower the minimum and to define an ecologically effective rainfall as one consisting of 0.15 inch, or more, and which occurs in a distinct rainy period. Whether subsequent study will establish another minimum does not concern us at present. It will be useful, if for no other purpose, to show how large a percentage of the total annual rainfall in the dry interior is of little or no moment to the native vegetation, and hence how very arid the region really is.

The effective rainfall for Oodnadatta, Copley, and Quorn was determined for a period of five successive years, and the results are presented in table 11. The last column of the table gives also the actual recorded rainfall for each of the years referred to. It will be seen that

TABLE 11.-Monthly effective rainfall at Oodnadatta, Copley, and Quorn, South Australia, for 1901-1906, in inches.

\begin{tabular}{|c|c|c|c|c|c|c|c|c|c|c|c|c|c|c|}
\hline & Jan. & Feb. & Mar. & Apr. & May. & June. & July. & Aug. & Sept. & Oct. & Nov. & Dec. & $\begin{array}{l}\text { Total } \\
\text { effec- } \\
\text { tive } \\
\text { rain- } \\
\text { fall. }\end{array}$ & $\begin{array}{l}\text { Total } \\
\text { rain- } \\
\text { fall. }\end{array}$ \\
\hline Oodnadatta: & & & & & & & & & & & & & & \\
\hline $1901 \ldots \ldots$ & 0.0 & 3.87 & 0.0 & 0.0 & 0.0 & 0.0 & 0.0 & 0.20 & 0.0 & 0.0 & 0.0 & 0.0 & 4.07 & 4.94 \\
\hline 1902. & 0.0 & 0.0 & 0.0 & 0.0 & 0.0 & 0.0 & 0.50 & 0.0 & 0.0 & 0.0 & 0.65 & 0.87 & 2.02 & 2.61 \\
\hline 1903. & 0.40 & 0.0 & 0.0 & 1.69 & 0.31 & 0.0 & 0.0 & 0.60 & 0.0 & 0.0 & 1.11 & 0.35 & 4.46 & 5.48 \\
\hline 1904. & 0.0 & 3.01 & 0.20 & 0.0 & 0.36 & 0.20 & 0.71 & 0.0 & 2.16 & 0.65 & 0.0 & 0.0 & 7.29 & 8.92 \\
\hline 1905. & 0.0 & 0.0 & 0.0 & 0.27 & 0.23 & 1.56 & 0.67 & 0.0 & 0.0 & 0.25 & 0.0 & 0.0 & 2.98 & 5.69 \\
\hline 1906 & 0.0 & 0.0 & 0.0 & 0.0 & 0.54 & 0.0 & 0.17 & 0.0 & 0.60 & 0.0 & 0.0 & 0.0 & 1.31 & 3.03 \\
\hline \multicolumn{15}{|l|}{ Copley: } \\
\hline 1901 & 0.0 & 2.67 & 0.0 & 0.27 & 0.0 & 0.40 & 0.0 & 1.71 & 0.32 & 0.25 & 0.0 & 0.0 & 5.62 & 6.49 \\
\hline 1902. & 0.0 & 0.0 & 0.0 & 0.0 & 0.0 & 0.0 & 0.15 & 0.0 & 0.58 & 0.0 & 0.48 & 0.0 & 1.21 & 1.95 \\
\hline 1903. & 0.0 & 0.0 & 0.86 & 0.20 & 0.60 & 0.0 & 0.16 & 0.67 & 2.21 & 0.0 & 1.76 & 3.25 & 9.71 & 11.53 \\
\hline $1904 .$. & .26 & 0.46 & 0.0 & 0.17 & 1.21 & 0.62 & 1.75 & 0.54 & 1.08 & 1.22 & 0.15 & 1.23 & 8.69 & 9.76 \\
\hline $1905 \ldots \ldots$ & 0.75 & 0.0 & c.o & 0.0 & 0.49 & 0.95 & 1.06 & 0.0 & 0.66 & 0.52 & 0.0 & 0.0 & 4.43 & 5.03 \\
\hline $1906 \ldots \ldots$ & 0.0 & 0.65 & 1.86 & 0.0 & 3.43 & 1.75 & 0.37 & 0.60 & 1.70 & 0.15 & 0.80 & 0.80 & 12.11 & 13.00 \\
\hline \multicolumn{15}{|l|}{ Quorn: } \\
\hline 1901. & 0.0 & 0.53 & 0.0 & 0.39 & 0.0 & 0.91 & 1.19 & 2.37 & 0.86 & 1.99 & 0.0 & 0.0 & 8.24 & 10.14 \\
\hline 1902. & 0.0 & 0.41 & 0.96 & 0.0 & 0.0 & 1.15 & 0.0 & 0.34 & 0.59 & 1.50 & 0.0 & 0.57 & 5.52 & 7.76 \\
\hline 1903. & 0.42 & 0.49 & 1.40 & 1.75 & 0.68 & 0.69 & 0.90 & 0.27 & 2.76 & 0.15 & 5.27 & 0.77 & 15.55 & 18.09 \\
\hline $1904 \ldots$ & 0.95 & 2.45 & 0.0 & 0.30 & 0.22 & 1.17 & 1.62 & 0.54 & 0.0 & 2.99 & 0.57 & 0.34 & 11.15 & 13.09 \\
\hline $1905 \ldots$ & 0.66 & 0.45 & 0.0 & 0.90 & 3.96 & 0.84 & 1.30 & 0.38 & 0.21 & 1.07 & 0.0 & 0.0 & 9.77 & 12.82 \\
\hline $1906 \ldots$ & 0.0 & 0.67 & 2.09 & 0.0 & 1.53 & 4.40 & 1.14 & 0.70 & 2.61 & 0.91 & 1.72 & 0.90 & 16.47 & 18.74 \\
\hline
\end{tabular}

TABLE 12.-Mean, highest, and lowest monthly rainfall at Oodnadatta, in inches, for a period of 26 years.

\begin{tabular}{|c|c|c|c|c|c|c|c|c|c|c|c|c|c|}
\hline & Jan. & Feb. & Mar. & Apr. & May. & June. & July. & Aug. & Sept. & Oct. & Nov. & Dec. & Year. \\
\hline Mean & 0.71 & 0.71 & 0.57 & 0.18 & 0.23 & 0.64 & 0.28 & 0.11 & 0.32 & 0.34 & 0.38 & 0.38 & 4.85 \\
\hline Highest.... & 5.18 & 4.16 & 4.32 & 1.79 & 1.54 & 27.71 & 1.68 & 0.60 & 2.21 & 2.03 & 1.41 & 1.79 & 8.92 \\
\hline Lowest... & ..... & $\cdots$ & $\cdots \cdot$ & $\cdots$ & . & $\ldots \ldots$ & $\ldots$ & $\cdots_{i k}$ & $\cdots$ & $\ldots \ldots$ & $\ldots \ldots$ & $\ldots$. & 1.54 \\
\hline
\end{tabular}


the percentage of what may be called the non-effective rainfall increases with the decrease in the total average rainfall. At Quorn, for example, it is 18 per cent, at Copley it is 19 per cent, and at Oodnadatta it is 30 per cent for the years under consideration. Assuming that these figures represent the average percentage of the non-effective rainfall, which may or may not be the case, and knowing the actual average rainfall for the three stations, the expected efficient rainfall can be easily calculated. For example, the average rainfall at Oodnadatta is 4.85 inches. This being the case, a correction for the percentage that does no good to the native vegetation would give an efficient average rainfall of 3.42 inches. The average rainfall for Copley is 8.70 inches, which would amount to 7.13 inches effective rainfall, and that at Quorn is 13.72 inches. At the latter station the effective amount would be 11.11 inches. The relation of the total, the effective and the noneffective, rainfall at Oodnadatta, Copley, and at Quorn is shown graphically in figure 11 . In 1906 the non-effective rainfall at Oodnadatta was 43 per cent of the total recorded for the year. Thus the effective amount of precipitation for the year at Oodnadatta was 1.7 inches. This exceeds the percentage of non-effective rainfall of each of the other stations whose records were studied and indicates (together with the average percentage of non-effective rainfall for the stations given above) that the curve of aridity falls more rapidly, as one goes from a less to a more arid station, than the curve of the rainfall itself. 


\section{VEGETATION AND PLANT HABITATS IN VICINITY OF OODNADATTA.}

\section{PHYSIOGRAPHY.}

The country to the south and to the west of Lake Eyre and Lake Eyre South, as seen from the railway, has a monotonous topography, although not without a certain diversity. As one goes west from Maree (Hergott Springs) the land-surface on every side, except to the south, is fairly level. Some distance on the south lies the northwestern spur of the Flinders Ranges, but in the other directions the general flat expanse is broken only occasionally by low hills or mounds. Maree lies on the southern edge of the great Australian artesian basin and in its vicinity, as elsewhere along the line of the railway, mounds mark the presence of springs. There are 50 or more of these springs in the southern and southwestern part of the basin. The water is charged heavily with mineral matter and upon evaporation leaves a calcareous deposit. Thus the travertine mounds are formed. The water flows out of the summit of the mounds and extends for a greater or less distance from the base. The mound springs thus can carry vegetation and are often the only green spots, truly oases, on a parched and barren plain.

But the leading characteristic of the country to the south of Lake Eyre South is its flatness. On every side it is a plain, and to the north it stretches as far as the eye can reach, a grayish-green plain that finally merges in a mirage, suggesting flat expanses of a lake. Shortly before reaching the station of Stuart's Creek the railway crosses what is probably the southern edge of the bed of the lake of earlier times, running below the level of the sea, and here, on the rare occasions when filled with water, it may be seen from the railroad. Thus, in July 1918, there seemed to be water in the south arm of the lake.

After leaving Stuart's Creek the railway ascends gradually until at Oodnadatta it is about 400 feet above sea-level. The topography becomes more broken and presents several features of especial interest. Beyond William Creek some worn-down pre-Cambrian hills extend, and flat-topped hills may be seen to the west, which are probably outliers of the desert sandstone tableland (Upper Cretaceous). Occasionally sandhills were seen lying toward Lake Eyre. The railway line also runs among low hills and along salt flats, and finally, not far south of Oodnadatta, it crosses a wide and poorly defined river bottom, which at the time of my visit was dry. Thus we have the leading topographical elements of the Oodnadatta region, namely, the lower plain, itself somewhat diversified, on which the railroad runs, the flat-topped hills, the sand dunes, and the drainage channels.

Oodnadatta, which is the present end of the railway running from Adelaide, and approximately 700 miles from that city, is situated near 
the western edge of the great Australian artesian basin. It is about 100 miles to the north of west of the northern end of Lake Eyre. The most important topographical feature of the immediate neighborhood of the town is the lower plain (Lower Cretaceous) on which it is situated. Outlying members of the higher plain, the desert sandstone tableland, can be seen to the westward (plate 1A). These flat-topped hills are a striking feature of the topography of the region. The surface both of the lower and of the upper plain is usually covered with fairly small stones, the gibbers, which were left by the wind after all fine material had been removed (plate 1B). Although a superficial view over the lower plain gives the impression that it is quite flat, when seen more closely such is found not to be the case. It is slightly undulating and there are shallow depressions, apparently wind-scooped, here and there, where gibbers appear to be wanting, and which are but a few inches below the general level of the plain. Such, as will be mentioned below, are in fact miniature oases which support a characteristic vegetation in the midst of a plain otherwise quite barren.

So far as I saw, the surface of the flat-topped hills, which are the remains of the upper plains, it is much like that of the lower plain, except that the effects of erosion are more marked. There are small depressions in this plain also, and it is covered with gibbers. Possibly, as will be remarked later, the upper plains constitute the most arid habitats of the great basin.

The most prominent water-course in the vicinity of Oodnadatta is Neales River. At Oodnadatta the river-bottoms are defined by low banks, and are possibly 6 feet below the general level of the lower plain. But as the river goes southeast on its way to Lake Eyre, the course widens and is not so sharply delimited as it is near Oodnadatta. Neales River and the Macumba River constitute the only rivers leading into Lake Eyre from the western side of the basin. At a point west of Oodnadatta and about a mile distant, the bottoms of Neales River are nearly a mile across. The surface of the bottoms, or flood-plain, is level. There is no continuous and well-defined water-course here, but at various places along the bottoms are depressions, 100 meters or less in length, which contain water after rains. These depressions have the appearance of having been gouged out by water at the time of high floods, which rarely occur. It is doubtful whether the water of the rivers ever empty into Lake Eyre. Just north of Oodnadatta there are flats which may possibly drain into the Neales River; and several miles farther north, as viewed from the summit of O'Halloran's Mount, there are extensive flats also, with narrow contributory channels, which probably act as reservoirs for the reception and catchment of flood-waters. All of these are probably related to the drainage of the main river.

Besides the plains and the drainage channels of whatever kind, in connection with the topographical features of the region one should 
also mention the sandhills and accompanying clay-pans situated 2 or 3 miles east and south of Oodnadatta. The sandhills lie on the lower plain and vary considerably in plan, extent, and height. The highest seen were estimated to have an altitude of about 15 meters above the plain and to be about 50 meters in diameter. They are round, oblong, or crescentic in plan. The windward slopes of some are gradual and the lee slopes steep. Ripple marks also are to be seen on most of the dunes. From such features it is concluded that not all of the sandhills are fixed. Adjoining the sandhills, or between them, are clay-pans which vary greatly in size, some being 1,200 meters, more or less, in diameter. The surface is hard and glistens in the sunlight. Although when seen the clay-pans were entirely dry, whenever rains occur they are covered with water which apparently escapes, mainly by evaporation, inasmuch as the surface of the pans is of fine texture, apparently silt, which would allow but relatively slow penetration.

In one group of sandhills the clay-pans appeared to extend beneath the dune, although this was not surely determined. If true, it would follow that under such a condition there might be important water reservoirs in the sandhills and at no great depth. "Soaks" among the sandhills, as possibly at Ooldea, may have such an origin and structure. Howchin (1909:103) says that sandy ridges and clay-pans form the southern plains of the central portion of Australia and occur largely on the eastern and northern sides of Lake Eyre, and points out that such an inland basin as that of Lake Eyre can not get rid of its worn-down material, the product of erosion, "such as occurs when the drainage of the country flows into the sea, whilst from a deficiency of moisture, vegetation is scarce and the soil but loosely held together. From this cause the soil and sand are constantly on the move."

From the foregoing sketch of some of the leading physiological features in the vicinity of Oodnadatta it will be clear that the character of the soil varies considerably. On the plains, for example, it appears to be fine sand with an admixture of pebbles of different sizes. The largest of these constitute the "gibbers," or desert pavement, which protect the fine soil beneath from being carried away by the wind and from rapid drying out. In the shallow hollows on the plains, as has already been alluded to, there are no "gibbers." This also is true on the flood-plain of Neales River, where, however, the small stones are largely wanting and the soil is relatively sandy. On the plains the topsoil appears to be about $50 \mathrm{~cm}$. deep, and on the flood-plain it is 2 meters, and probably much more, in depth.

In places on the plains where erosion has occurred and the substratum is exposed, it is seen to be of a white color and often of considerable thickness. How generally this extended was not learned. From the appearance of the material it was assumed to be gypsum, although in certain places where the layer of material was thin, as where it covered 
stones, it may well be travertine or desert limestone. The nature of the sandhills has already been mentioned and need not be taken up further. As to the clay-pans of the sandhill neighborhood, it need only be said that in them, as elsewhere where the drainage is poor or lacking, there is an excessive accumulation of salts. In the clay-pans the flooding water is at first fresh, but as it evaporates it becomes highly charged, and upon drying leaves the salts in the fine silt or on its surface. In other situations during dry seasons salts are frequently exposed in considerable quantity, especially under conditions of poor surfacedrainage. It seems probable, however, that where the salts are not present in the soil solution in sufficient quantity to form a visible crust upon the surface of the ground when the water has evaporated, as on the lower plain especially, yet they are relatively abundant. This characteristic of the soil of all arid regions is probably nowhere more marked than in the vicinity of Oodnadatta.

So far as regards the water relations of the different physiographical areas mentioned, it would appear from inspection and from the character of the soil that they may be said to be as various as the areas themselves. At the one extreme should be placed the flood-plain of Neales River, which receives not only water directly from the rains, but also such as comes to it from the drainage of the river system of which it is a part. The gradient of the flood-plain is apparently slight, the soil is deep and relatively coarse-grained, and there is no continuous and well-defined channel at the place visited. All of these features make for the maximum reception, storage, and retention of water. At the other extreme should probably be placed the flat-topped hills, representing the upper plain. Here the water is merely lost and not received by run-off, and the soil is moistened directly by the rains and in no other way. Percolation of the rains into the soil is indeed forwarded by the presence of stones of various sizes, but is relatively slow because of the fineness of the soil. Only in the slight depressions which are the centers of diminutive drainage systems is there appreciable accumulation of water after rains; otherwise, there are no proper soil reservoirs for water retention. However, owing to the closely fitted mosaic, the "gibbers," the water is conserved very much better than would otherwise be the case.

The sandhills and the lower plain occupy an intermediate position with respect to the water relation, although their relative position is not very clearly defined. So far as regards the quality of the soil solution and the retention and storage of the soil moisture, the sandhills are to be considered less arid than the lower plain, but where the latter joins higher ground, as the upper plain, it may receive seepage water, and in this regard only the water relation of the lower plain can be said to be more favorable than that of the sandhills. Other than this the water relations of the lower plain are about the same as 
the upper one. In the vicinity of Oodnadatta, however, the soil solution of the lower plain probably carries a larger percentage of salts, which, as will be remarked below, makes for physiological dryness. The sandhills probably constitute excellent reservoirs for water, and through the rapid drying-out of the surface of the soil the capillary chain is broken and evaporation into the air above the ground is either wholly stopped or at least it is very decidedly retarded and reduced to a quantity that for practical purposes can be neglected. On the other hand, there are no indications of water erosion among the sandhills, and such probably does not occur.

Unlike soil of a fine physical character, as, for example, that of the plains, prompt penetration of the rains takes place even if the soil at the time is air-dry and none is lost by run-off. The dust mulch on the surface is probably $30 \mathrm{~cm}$., more or less, in thickness, and the soil beneath, of homogenous sand, is moist to a depth dependent only on the amount of the rains. The only water lost from such depths is through the plant covering. The sandhills, therefore, have water relations which are considerably more favorable than would appear from a superficial examination.

In the other areas, such as have poor surface drainage, the amount of water received and also in certain instances retained must be said to equal, if not to exceed, that of any of the other areas. In such areas the degree of aridity is related to the concentration of the soil solution. In the case of the clay-pans, for example, when first flooded, as previously mentioned, the water is fresh, or but slightly brackish, and this is indicated by the character of the plant and animal life to be found in them at the time. As the water escapes by evaporation, however, the salts become more and more concentrated until only such forms as are especially adjusted to withstand such dense solutions are able to survive. Carrying possibly not a small amount of moisture, such areas are nevertheless intensely arid, speaking in a physiological sense.

From this sketch of the leading physiographic features of the vicinity of Oodnadatta, it can be seen that there are about four or five well-defined plant habitats. These are the upper and lower plains, the flood-plain of Neales River and its branches, the sandhills, and the clay-pans, with which might be included other areas having poor drainage. As will be shown later, these areas have for the most part characteristic vegetation, as might be expected from their marked differences, some of which have been outlined above. 


\section{CLIMATE.}

\section{RAINFALL.}

The most arid part of South Australia, as well as of Australia as a whole, is situated in the Lake Eyre Basin, as has already been pointed out. The character of the rainfall for Oodnadatta may be taken as representative of other portions of this intensely dry region. Apparently the station with the least average rainfall is Kanowana, where it is 4.33 inches annually; at Oodnadatta, however, the average is 4.85 inches. The monthly average distribution of the rainfall at Oodnadatta is given in table 12 , which shows that the seasonal rains are fairly equally divided, although averaging highest in the summer. Thus, at Oodnadatta the average is 1.80 inches in summer, 0.98 inch in autumn, 1.03 inches in winter, and 1.04 inches in spring. As table 12 suggests, the actual rainfall month by month for different years is very unequal in amount, so that a table of averages does not have the significance it otherwise might possess. The seasonal periodicity, so well marked over much of the state, is accordingly not so dependable at Oodnadatta and in the Lake Eyre Basin. However, as has just been indicated, the rains of summer, undependable as they may be and slight as they are, are nevertheless rather more in amount than those of any of the other seasons; and it is not impossible that the adjustment of certain of the native plants to their environment is sufficiently delicate so as to largely hinge on just such relatively small differences in the seasonal rainfall. So far as the character of the individual storms is concerned, relatively few of them are of so large amount as to be mainly lost by superficial run-off. On the other hand, a remarkably large percentage of the rainfall occurs in amounts too small to directly benefit plants. The proportion of the total rainfall which occurs in separate storms, amounting to 0.15 inch or less at Oodnadatta, lies between about 17 and 56 per cent of that for the year, as shown by the rainfall records of 1901-1906, inclusive (table 11). The average monthly effective rainfall for those years is as follows: January 0.06, February 0.64, March 0.03, April 0.32, May 0.24 , June 0.29, July 0.34, August, 0.13, September 0.46, October 0.15 , November 0.29, and December 0.20 inch. According to these records, therefore, the storms of summer, so far as the effective rainfall is concerned, are considerably less than those of winter. Inasmuch as the actual summer rainfall exceeds that of winter, it would be of much interest and importance to know, when a long series of years is taken into account, whether over such long period the effective rainfall would hold the relation above shown to be the case during the years 1901-1906, inclusive. 


\section{Temperature.}

As would be expected from the geographical relations, including the altitude of Oodnadatta and of the Lake Eyre Basin in general, extreme temperatures are the rule. The summers are very hot, the daily variation in temperature is relatively great, and the minimum temperatures of winter are lower than might be expected for the latitude. These features, of course, are to a large degree associated with a low rainfall and low relative humidity. The stabilizing influences of water and of water-vapor are largely wanting. Thus the air, and objects on the surface of the soil, including the vegetation, are quickly heated under the very favorable conditions of insolation obtaining, and conversely the radiant energy rapidly escapes with the passing of day. For these reasons there are, as table 7 indicates, many days during the year when the air has a temperature of over $90^{\circ} \mathrm{F}$, and, on the other hand, many nights when an air temperature of less than $40^{\circ} \mathrm{F}$. is recorded. ${ }^{1}$ In fact, in. every month, except June and July, a temperature of $90^{\circ} \mathrm{F}$., or above, is reached, and in 7 months of the year the night temperatures drop to below $40^{\circ} \mathrm{F}$. The extremes thus far recorded at William Creek, about 100 miles from Oodnadatta, are $119^{\circ} \mathrm{F}$. and $25.3^{\circ} \mathrm{F}$. for a period covering 28 years.

A summation of the mean monthly temperature for Adelaide, Port Augusta, Farina, and William Creek shows that the total amount of heat received increases at these stations in the order given: Adelaide, $747.8^{\circ}$; Port Augusta, $793.9^{\circ}$; Farina, $808^{\circ}$; William Creek, $822.6^{\circ} \mathrm{F}$.

It is not likely that the temperatures attained at Oodnadatta, or in the Lake Eyre Basin, are so high as to materially injure the perennial vegetation. On the other hand, a large amount of heat is required for the growth and development of such plants. Aside from this feature, it is probable that a leading effect of high temperatures on the vegetation, especially perennials, is an indirect one, namely, the effect of such temperatures on the relative humidity of the air, and hence on the rate of evaporation. The capacity of the air to absorb water-vapor increases directly with the temperature. Hence, it is found that the drying power of the air is markedly greater where the temperatures are higher, other conditions being equal, than where they are less. The following will illustrate the point: The average mean temperature for Adelaide is $63^{\circ} \mathrm{F}$. $\left(17.2^{\circ} \mathrm{C}\right.$.) ; for Port Augusta it is $66.2^{\circ} \mathrm{F}$. $\left(19^{\circ} \mathrm{C}\right.$.) ; for Farina it is $67.3^{\circ} \mathrm{F}$. $\left(19.6^{\circ} \mathrm{C}\right.$.) ; and for William Creek it is $68.6^{\circ} \mathrm{F}$. $\left(20.3^{\circ} \mathrm{C}\right.$.). The weight of aqueous vapor in a cubic meter of saturated air for these temperatures is as follows: 14.4, 16.1, 16.6, and 17.4 grams, from which it is seen that an amount capable of producing saturation under the mean-temperature conditions at Adelaide, and assuming the equality of other conditions, would not bring about saturation at William Creek, but only about 83 per cent of saturation.

\footnotetext{
${ }^{1}$ See the records for William Crcek, table 7.
} 
GENERAL FEATURES OF FLORA OF SOUTH AUSTRALIA.

\section{THE NORTHERN PORTION OF SOUTH AUSTRALIA.}

The flora of the northern portion of South Australia has a marked xerophytic stamp. As much, however, can be said for most of the perennials, if not all, in other portions of the state having a much larger rainfall. As Taylor remarks, possibly with another idea in mind, "it differs in degree according to the rainfall, but not in kind" (1918:89). This is possibly the most remarkable feature of the vegetation of this intensely dry region. That is to say, there are possibly no perennial forms peculiar to it as such-for example, as the different types of succulents developed in other arid and semi-arid regions, or possibly in regions which are desertic. There also are apparently no deciduous species.

In other dry regions some of the species are deciduous. For example, the acacias of the Sahara, as well as those of the southwestern United States, have foliage which falls away with the seasons; and in the arid southwestern part of the latter country a species (Fouquieria splendens) occurs which is deciduous with respect to the occurrence of the rains, losing and forming the foliage perhaps several times during the year, in a manner directly connected with the rains and the intervening dry spells. Therefore, there may be possible not a little variation in plants in extremely arid regions. Thus, although the perennial flora of the far north has apparently little or no striking peculiarities which set it apart from that of the regions of South Australia more highly favored with rainfall, there is still not a little diversity in it.

Among the most interesting trees of the dry region are several species of Acacia which show important morphological, as well as physiological, differences. Certain of the hakeas exhibit remarkable differences as between species and marked adjustment to an arid environment. Of the shrubs, those of the genus Eremophila are of especial interest. Out of the 39 species, including those now put under Pholidia, Tate gives 17 species as occurring in the northern portion of the state. Of the shrubs, this is the desert plant par excellence. But the halophytes of whatever species constitute the most prominent element of the flora of this region. Tate gives 54 species of the Chenopodiaceæ and Amarantaceæ from the far north, most of which are highly salt-resistant. There are a few succulent annuals, or half shrubs. Among these are species of the Zygophyllaceæ and Calandrinia balonnensis (Portulaceæ); the latter bears large, succulent leaves and is much sought after by animals. Stuart's pea, Clianthus dampieri, is one of the most showy of the annuals.

Of the grasses, among the most frequently met are the "bunch" forms, as Triodia irritans and Spinifex paradoxus, which are widely distributed in the interior of the continent. In addition, according to 
Tate, there are 55 species of grasses, mainly annual, which are to be found also in northern South Australia. These for the most part are to be seen only after rains, possibly mainly those of summer.

\section{VEGETATION OF THE LAKE EYRE BASIN.}

As one enters the Lake Eyre region by the railway, the general impression is had, which becomes stronger upon further acquaintance with the region, that the total amount of perennial vegetation has suddenly become less, despite the large halophytic population. Moreover, the larger elements of the vegetation are more and more restricted to the water-courses and a relatively small amount is to be seen venturing away from them. The differences noted are possibly most marked with the tree flora. Clearly such a generalized statement is difficult, if not impossible, to demonstrate. One would, of course, expect a falling off in the amount of vegetation in a region having only 5 inches as opposed to one having nearly 9 inches-for example, that about Copley. But the point I wish to make is that the difference is greater than the difference in the recorded rainfall would lead one to expect. To illustrate the idea crudely, we may suppose the amount of vegetation and the amount of rainfall to be represented in a figure by two curves. The curve representing the amount of vegetation is assumed to decline parallel to that representing a decrease in the precipitation. However, with the decreased rainfall there comes a rapid increase of other climatic factors making for aridity, and especially there occurs, in the Lake Eyre region, a relatively large proportion of non-effective precipitation. We therefore get a diverging of the vegetation-rainfall curves which at the last is very sharp. The sudden falling of the vegetation curve I believe to be directly related to the large percentage of non-effective rainfall, although with it there naturally must be associated an intensification of other environmental physical factors working toward the same end. In other words, the effect is as if in place of contrasting regions having about 5 and 9 inches of rain, we are contrasting regions whose effective rainfall may be said to be about 3 and possibly 8 inches.

\section{VEGETATION AT OODNADATTA.}

A general idea of the amount of the perennial vegetation in the vicinity of Oodnadatta may be had by ascending O'Halloran's Mount, which is about 4 miles to the north of the village (plate 1A). This low hill is evidently a detached portion of the upper plain and it commands a very good view of the desert. As one surveys the surrounding country he is at first struck with the paucity or rather with the want of plant covering. In every direction the wide-spreading plains and flat-topped hills appear quite barren. The gibbers glisten like polished mirrors in the sun, but otherwise a monotonous reddish-brown color prevails. There are thus apparently no plants to enliven the scene. 
The effect is as if no living thing ever found or ever could find a lodgment and an abiding-place in the expanding waste. More careful examination, however, reveals the presence of plants. Across the lower plain, for example, there extend narrow ribbons of vegetation. These converging make gray-green bands and mark the drainage channels where only masses of vegetation are to be found. The inconsequential plant life of the plains as a whole does not appear on such a general view. Slight as is the present-day vegetation of the region, it perhaps is a matter for surprise that there is so much. Aside from the unfavorable physical environmental conditions which make for few plants, there are also biotic environmental elements which are relatively very destructive. Thus the region has supported and now supports an aboriginal population which depends wholly on natural products, animal and vegetable, for its living; and relatively recently the white inhabitants have drawn heavily on every useful native plant. Herbivorous animals of many kinds have also made destructive inroads on the vegetation. Just how all of these biotic factors have affected the flora as a whole will, of course, never be known, but that they are, and long have been, of great importance in many ways can not be seriously questioned.

\section{VEGETATION OF THE PLAINS.}

The vegetation of the plains was observed in four separate localities on the upper and on the lower plains. So far as these situations are concerned the perennial vegetation was found to be very meager indeed, but there were a few annuals which had sprung up following a small rain of the week preceding my visit. Both classes of vegetation, however, were for the most part restricted in distribution to the small and slight depressions on the plains or to the diminutive drainage channels frequently associated with them. Taken as a whole, aside from such relatively favorable situations as above mentioned, the plains gave little suggestion of plant life. Among the annuals were found Brachycome ciliaris and Senecio gregorii, and among the perennials Bassia lanicuspis(?), which occurred very sparingly, and species of Eremophila. The Eremophilas were the most striking and interesting of the perennials. Of these, Eremophila freelingii (plate 2, A and B; plate $3 \mathrm{~B}$ ) appeared to be most numerous and was found on both plains. Plate 2B shows a typical example of the species in place on the upper plain. It is a much-branched shrub about a meter in height and bears dullgreen leaves, narrowly oblong in form, mostly at the end of the branches. The species is fairly rare on the plains, but in and along the drainage channels the population is more abundant and the individuals of a larger size than on the plains proper. In addition to the species referred to, $E$. latrobei (plate 3c) has a distribution about like that of $E$. freelingii, but is possibly not so abundant. In a wash at the 
south base of O'Halloran's Mount may be found E. neglecta (plate 5в). In the same situation a few examples of an undetermined half-shrub and several annuals, also undetermined, were seen.

Although the species mentioned in the preceding paragraph are to be found very sparingly on both the upper and the lower plains, the former was especially in mind when writing the description; and, so far as one can judge, the vegetation of this plain, at least in the vicinity of Oodnadatta, has been little affected by the presence of man. No trees occur on it and the shrubs of the plain are apparently not found useful either by man or beast. On the lower plain, however, there are indications that formerly the number of individuals may have been greater than now. Dried remains of salt bushes are to be found here and there, and persons familiar with the region say that such forms were formerly fairly abundant on this plain. It seems probable, also, that after heavy rains, which occur at widely separated intervals, the face of the lower plain may be clothed with annuals, including grasses, and that they may be of such size and abundance as to completely hide the surface of the ground; and, although there are no trees on this plain, they may be found along water-courses connecting it with the upper plain-for example, Acacia cambadgei occurs sparingly in such a drainage channel leading from the upper to the lower plain at a place about 4 miles to the west of Oodnadatta (plate $3 \mathrm{~A}$ ). Eremophila neglecta and $E$. latrobei also occur in such situations.

\section{VEGETATION OF AND ABOUT THE SANDHILLS.}

Across the lower plain and about 3 miles to the east or southeast of Oodnadatta is an area where sandhills and clay-pans are the most characteristic features of the physiography. On the way to the hills the plain is found to sustain a sparse population of saltbushes of various kinds which were not studied particularly, and viewed from the plain the distant sand ridges appear to be fairly well covered with vegetation. Upon drawing near the hills a comparatively large number of small trees and shrubs are also to be seen. But the near view of the sandhills reveals the fact that the vegetation is very diffuse and composed almost exclusively of a single form. The clay-pans which lie between or by the sandhills were found to be devoid of vegetation, although when flooded such a form as the "nardoos," Marsilia spp., may be found. On the rims of the clay-pans saltbushes occur, but not in abundance.

The characteristic species of the sandhills is the sandhill mulga, Acacia linophylla. On the dunes the species has the habit of a large shrub, but occasionally a central stem is formed. It is about 5 meters in height. The habit of the species is shown in plate 4B. The leaves, or rather phyllodia, are relatively few in number (plate $5 \mathrm{~A}$ ), about $15 \mathrm{~cm}$. in length and about $2 \mathrm{~mm}$. wide. They are fairly rigid and have an attenuated but not a spiny tip. At the time of my visit, 
July 11, the species was flowering and the plants were covered with ants in immense numbers, which appeared to be seeking the nectar of the flowers. The small size of the trees and the large amount of dead wood attested to the very difficult conditions under which the species was living. So far as the roots could be seen, it was found that many were very near the surface, being often exposed through wind erosion. Although no long horizontal roots were found, it is known that in the mulga and under analogous conditions very long superficial roots are formed. Owing to this fact and to their being of a fairly uniform size, they are used by the aborigines in the making of spear handles. Although the mulga was the only woody perennial found in the sandhills, a species of "spinifex" or bunch grass appears here and there, and is one of the most characteristic plants of the arid interior.

On the plain and at a relatively short distance from the base of the sandhills some shrubs and trees are to be found. In places they are relatively abundant and also fairly large. The shrubs are wholly or mainly Eremophila neglecta (plate 5в), about 2 meters high and well clothed with leaves. The trees are of but a single species, "dead finish," Acacia tetragonophylla, which is of wide occurrence in the drier portions of South Australia. The habit of the species is shown in plate $4 \mathrm{~A}$ and plate $6 \mathrm{~A}$. A leading and striking characteristic of the latter species lies in the small size of the phyllodia, which are borne in relatively large numbers, fairly well distributed on the smaller branches. The relative abundance of the species at the base of the sandhills is apparently attributable directly to the comparatively favorable water relations of the place.

The soil is fairly deep and covered with a sand mulch blown from the neighboring hills. There is a substratum of a white and not especially hard material which has the appearance of travertine limestone and indeed may be that. Whether this prevents the deeper sinking of water or absorbs it, to be yielded again to the plant-roots, was not determined. In case the substratum underlies the sandhills as well, which may be the case, a further reason for the relatively abundant vegetation at their base would be found. So far as the substratum is concerned, it was found to crop out along the path to the hills, and in such cases it formed a hard surface quite as in the "caliche," or desert limestone, in the more arid parts of the United States, in southern Algeria, and other dry regions. Moreover, under such conditions it is fairly impervious to water.

In the habitat at the base of the sandhills there were found a few specimens of the phanerogamous parasite Loranthus exocarpi on Eremophila neglecta. The paucity of this type of vegetation in the vicinity of Oodnadatta forms a striking contrast to the conditions obtaining at Copley, where the mistletoes are very numerous. 
Although there is thus seen to be a comparatively abundant perennial flora at and near the sandhills, yet the largest number of woody plants about Oodnadatta, especially the largest number of trees, is to be found in water channels of whatever kind, either Neales River or washes at the bases of the flat-topped hills. As viewed from the vantage-point of the upper or even the lower plain (plate $5 \mathrm{c}$ ), the Neales River bottoms has a considerable tree population, and particularly a large number of shrubs. The present-day shrub and tree population of the flood-plain of the river can not be taken as indicative of what must have been the condition in earlier times. The inhabitants of the nearby town have actively removed all trees large enough to supply fuel. The shrubs, however, have probably very largely escaped such inroads. The same remark would also apply to the neighboring washes, where the water relations are suitable for some tree-growth.

Of the species now to be found on the flood-plain of Neales River, the most conspicuous are Eucalyptus rostrata (plate 4c) and species of Acacia, among which are A. cambadgei, A. tetragonophylla, and $A$. stenophylla. There are also several species of saltbushes, several shrubs whose identity was not determined, and some annuals. Of the trees, Acacia cambadgei is possibly the most numerous. This is the "stinking" acacia, or "gidya," the name given it by the aborigines, which is said to refer to an edible (for aborigines!) larva which is to be found beneath the bark. The tree attains a height of 10 meters or more and has a compact habit of growth. Like the other species of Acacia growing in the far north, true leaves are not present on the mature plant, but their place is taken by phyllodia. In the case of the gidya the phyllodia are fairly large as well as abundant, so that a distinctly leafy effect is produced (plate 6A) and the shade cast is dense-a rare occurrence in desert plants.

A. tetragonophylla is also a small tree, but with a foliar habit quite different from the species last mentioned. Its phyllodia are needleform, 8 to $28 \mathrm{~mm}$. in length, and may occur in groups of a few each. They fall away fairly easily and the ground beneath the trees is usually thickly covered with them. It appears probable that the shedding of the phyllodia should be considered a very effective means of reducing the evaporation surface and hence of cutting down excessive loss of water during especially severe drought. The foliar habit of $A$. stenophylla is unlike that of either of the species above mentioned. The species is a small tree or a large shrub at Oodnadatta and true leaves are formed on young shoots, although they are soon cast off, phyllodia taking their place (plate 6в). The phyllodia are various as to form and size, but in general they are long, narrow, and even linear in the extreme form. In the portions of a plant which are subjected to the most intense illumination the phyllodia assume an upright position, but where shaded they are pendant. 
The root-habits of certain species growing along the washes or by the separate basins on the flood-plain of Neales River were studied as far as possible. Observations of roots exposed by the washing away of the banks indicate that the general course of the roots of the trees was similar. Taking Eucalyptus rostrata and Acacia cambadgei, especially, it was found that a prominent portion of the root-system is made up of large horizontal members which may extend for a long distance from the central stem (plate $7 \mathrm{~A}$ ). Thus the superficial roots of Eucalyptus were seen to reach out 9 meters or more and to lie at a depth not exceeding $60 \mathrm{~cm}$., although the distance beneath the surface of the ground was usually much less. In addition to horizontal roots, vertical ones were found, but none lying at angles between. In the case of several shrubs whose roots were observed, it was found that an analogous condition obtained-that is, there was evidence of direct reaction to the type of rainfall which is especially characteristic of the region. In Acacia stenophylla shoots arise from the superficial roots (plate $7 \mathrm{~B}$ ), with a resulting and characteristic dense thicket formation. Such vegetative reproduction was seen in several species in the other regions visited, especially at Quorn. 


\section{THE COPLEY ENVIRONMENT.}

\section{PHYSIOGRAPHY.}

The topography and hence the plant habitats in the immediate neighborhood of Copley are extremely varied, owing mainly to the relation of the region to the Flinders Mountains. The main portion of the north end of the Flinders lies to the east, between Copley and Lake Fromme, but a lesser part is between the village and Lake Torrens on the west. Copley is thus in the bifurcation of the range, with outlying hills and low mountains within one mile or more on either side. The plain at Copley constitutes little more than a valley, but it widens to the north, becomes lower in altitude, and soon constitutes a leading feature of the topography. Copley lies between the 500-foot and 1,000 -foot contours and hence is near the upper level of the Cretaceous beds (Taylor, 1918:87). In the Flinders to the east are peaks which are among the highest of the entire ranges, including Mount Serle, the Freeling Heights (3,120 feet), and Mount Benbonyanthe $(3,470$ feet). The altitude of the division of the Flinders to the west of Copley is 2,000 feet or less. The observations upon which the present study is based were made within a 15-mile radius of Copley and were confined to an altitudinal range of approximately 1,000 feet. Within this small region, however, there is to be found a bewildering array of hills, valleys, slopes, washes, and flats which would be beyond the purposes of this study to describe accurately or in detail. The device will be resorted to, however, of attempting a characterization, so far as possible from the data at hand, of such of the habitats as appear to be of most interest in connection with this study.

The Flinders on either side of Copley are for the most part of the Cambrian age, but there are also Mesozoic rocks. Thus the slate hills with vertical strata to the east of the town are possibly of the former, and the table mountain just southeast is of Mesozoic. The latter is part of the desert sandstone previously seen at Oodnadatta and which formerly extended over most of central and northern Australia (Howchin and Gregory, 1909:93). Thus the underlying rocks, and consequently the soil derived by disintegration from them, have a widely different physical character. Future ecological studies in the vicinity of Copley may well correlate the distribution of the vegetation with the nature of the soil and with the rocks from which it has been derived, as has been done by Osborne in the Mount Lofty Ranges near Adelaide (1914:114).

Such observations as were made by me on soils will be given, together with the running account of the most striking features of each of the habitats studied. It will suffice to say, as would be supposed from what is known of the local geology as above suggested, that the soils are very various. For example, on the plain about the village 
there is a large amount of sand, some of fine grain and easily shifting with the wind. For this reason one finds fences covered with sand drift and sandy hillocks. There are also a few moving dunes of small size. In the low hills the soil appears to be all or part clay, or at least of very fine structure, as a sandy loam. There is evidently very little humus. So far as the depth of the soil is concerned it can be said to vary greatly. On the plain near Copley it is 4 meters or more. Among the hills, on the other hand, there are many areas where the rock is barely covered with soil, and of course there are many outcrops in which soil is entirely wanting. In any region, such, for example, as that about Copley, where a small rainfall is a prominent environmental factor of plants, the nature of the soil, including its depth, is of very great importance in shaping the character of the plant covering as well as its distribution. This fact is largely based on the circumstance that the soil constitutes the sole reservoir for the reception and storage of water.

Owing to the broken topography the water-courses of the region are not only numerous but also in many regards extremely varied. In some the gradient is marked, in others it is relatively slight. The channels may be very well developed and hence considerably below the adjoining plain, or slope, as the case may be, or the converse may be true. The leading drainage channels of all sorts are contributory to Leigh's Creek. This stream, dry much of the year, takes its origin a few miles to the east of Copley in the Flinders Ranges, and running northward it joins the Fromme River and ultimately discharges into Lake Eyre. To the south of Copley, and a little beyond the region studied, the streams run in the opposite direction and into or toward Lake Torrens. Although the drainage is generally very well defined, there are relatively small separated basins, mainly on the Copley plain, which have inadequate drainage or no surface outlet. In such depressions there is a large accumulation of salts.

It will be seen from the above sketch that the leading physiographic divisions or units can be said to be the hills, the Copley Plain, and the washes. For convenience, the hills will be divided into (1) the Mount Deception Range, such of the Flinders Ranges as lie to the west of Copley, and (2) Table Mountain and Mount of Light, with the nearby hills, to the east. For the purpose of further distinguishing the localities to be referred to below, they will be mentioned in reference to the roads which lead to them, as follows:

North of town: Myrtle Springs road crosses the plain northwest of the village, goes through the low hills to the east of the Mount Deception Range, and finally through that range. Yudnamutana road goes north and northeast of town, passes along the western side of the Flinders Ranges, and at length penetrates them; this road also crosses the plain and runs over low hills, where it passes out of the Copley vicinity. 
East of town: The Mount Serle road crosses the plain for about a mile and then enters the undulating hill country. It passes to the north of the Mount of Light, and winds between lower hills until it also passes beyond the Copley district.

South of town: The Beltana road goes in the midst of the Copley Plain for several miles and at length makes its tortuous way through the Flinders to Beltana and southern towns.

\section{CLIMATE.}

\section{RAINFALL.}

The climate of Copley can be characterized as arid, with cool winters and hot summers. Owing to its position, about midway between the southern extension of the summer rains and the northern limit of those of winter, some precipitation is to be expected in every month of the year; for the same reason, the rainfall of any season is extremely variable. In table 13 are presented rainfall data for a period of 35 years, supplied by the Commonwealth Bureau of Meteorology. It will

TABle 13.-Average rainfall at Copley (Leigh's Creek), South Australia, based on records for 35 years.

\begin{tabular}{|c|c|c|c|c|c|c|c|c|c|c|c|c|c|}
\hline & Jan. & Feb. & Mar. & Apr. & May. & June. & July. & Aug. & Sept. & Oct. & Nov. & Dec. & Year. \\
\hline Mean. & 0.67 & 0.52 & 0.80 & 0.54 & 1.06 & 1.11 & 0.50 & 0.69 & 0.75 & 0.47 & 0.53 & 0.76 & 8.40 \\
\hline Highest. & 4.76 & 3.05 & 4.70 & 3.78 & 5.84 & 4.72 & 2.24 & 3.02 & 3.58 & 2.06 & 2.35 & 3.78 & 15.64 \\
\hline Lowest. & $\cdots$ & & & . & $\cdots$ & $\cdots$ & $\cdots$ & . & $\cdots$ & $\ldots$ & $\cdots \cdots$ & $\cdots \cdots$ & 1.54 \\
\hline
\end{tabular}

be seen that the extreme variation in yearly precipitation is from 1.54 to 15.64 inches. The seasonal averages are as follows: Summer, 1.95; autumn, 2.4; winter, 2.3; and spring, 1.76 inches. Another feature of the rainfall at Copley does not appear in the table, but was seen in daily reports very kindly put at my disposal by Mr. Bromley, meteorologist at Adelaide. This relates to the maximum rainfall for one day. Records covering 6 years, 1901 to 1906, inclusive, were examined. The greatest rain for 24 hours during this period was on December 28, 1903, when 3 inches were reported. This, it will be noted, is about twice as much as occurred during the year of minimal rain as given in the table.

The rainfall at Copley, however, as has been shown in another place, is not always in amount sufficient to be of direct use to plants. In fact, it was shown that for the years 1901 to 1906, inclusive, approximately 19 per cent of the rain occurred in showers of 0.15 inch or less. The amount of 0.15 inch rainfall was placed as the minimum after the following observations had been made at Copley, supplemented by others at Ooldea. On August 20, after a slow rain amounting to 0.21 inch, fairly fine soil containing some sand on the plain was found to have been moistened to a depth of $4 \mathrm{~cm}$., and coarser soil also on 
the plain was wetted to a depth of 8 to $9 \mathrm{~cm}$. The observations were repeated a few days later with substantially the same results. In both instances the rains were followed by drying weather, so that a large percentage of the moisture taken into the soil must have been lost quickly by evaporation. It was assumed that had the rainfall been 25 per cent less, the penetration would also have been very much less, and the amount of water lost by evaporation would bave been relatively greater with respect to the amount recorded. Therefore, under such conditions there would be very little, if any, available for the use of plants, more especially for the use of perennials. However, as will be shown below, there is no doubt that, given favorable soil conditions, a rain amounting to 0.20 inch penetrates the soil sufficiently to moisten the horizon occupied by the roots of many annuals and also by a portion of the horizontal roots of certain perennials.

\section{TEMPERATURE.}

The temperature records for Copley were not examined by me, but the Commonwealth Bureau of Meteorology very kindly supplied the records for Farina, 40 miles farther north, which have been accepted as illustrating the conditions at Copley. A summary of these records for Farina has been given in table 7, which shows that the highest shade temperature reported for the station, for a period of 28 years, was $119^{\circ} \mathrm{F}$. The absolute minimum was $25.3^{\circ} \mathrm{F}$. The annual range may be considerable; for example, in 1912 the minimum reported was $27.3^{\circ} \mathrm{F}$. and the maximum was $118^{\circ} \mathrm{F}$., a total range of $90.7^{\circ} \mathrm{F}$. During the same year the mean daily range was $18.6^{\circ} \mathrm{F}$. and the maximum range observed during the course of one day was $53^{\circ} \mathrm{F}$. The mean yearly temperature at Farina is more than $10^{\circ} \mathrm{F}$. below that at William Creek, as representing Oodnadatta, and it is nearly $4^{\circ}$ higher than that at Adelaide. For other details, reference can be had to table 7 .

\section{VEGETATION OF THE COPLEY REGION.}

The most striking features of the flora of the lowlands between Marree (Hergott Springs) and Copley are its abundance and the fact that it is practically all of one type, namely, halophytes. Viewed from some distance, the relatively slight individuality of the species is lost and the plains appear closely covered with a uniform growth. In and along washes and on the slopes of the hills, however, the vegetation is generally composed of sclerophyllous shrubs and trees which vary greatly in size, form, and occurrence. Even at this day, and in spite of the heavy demands of whatever nature made on the native vegetation by the white inhabitants, there is a remarkable wealth of plants, not only as regards species but also as to number of individuals; and it is to be remembered that the rainfall of the region is by no means heavy. At Marree it is 6.08 inches and at Copley 8.40 inches, of 
which about 20 per cent occurs in amounts too small to benefit plants directly.

The following glimpses of the vegetation, its leading character, and occurrence, taken at a few well-marked localities close to Copley, should supply in a broad way sufficient data to reconstruct its general features.

For convenience the description of the vegetation at Copley will be grouped around the following physiographic units (habitats), which will be made the centers of "communities," but they are probably not of equal value, as will be at once apparent:

(1) "Alkali" plains, or lowlands, including slopes and benches where halophytic vegetation points to an excess of salts in the soil.

(2) Low hills and the slopes of higher hills, or low mountains, as of the Mount Deception Ranges west of Copley and the lower portions of the Flinders Ranges to the east. This includes the subaerial delta fans(?) on either side of the Copley Plain. The leading features of the hill habitat can be said to be $(a)$ possible variations in aspect; $(b)$ a relatively good water relation through altitude and relation to higher hills or mountains; and $(c)$ presence of rock outcrops with corresponding paucity of soil whose nature is determined by that of the rocks.

(3) The Mount Deception Range immediately west of Copley.

(4) The washes or streams in the hills and lowlands.

\section{Vegetation of the "Alkali" Plains.}

The most important component of the vegetation of the lowlands, particularly of the Copley Plain, consists of halophytes in bewildering variety. These in large part are very similar in size and in general appearance and it needs fairly close study to distinguish many of them. They are $50 \mathrm{~cm}$. more or less in height and usually of a grayish-green color; but some are small annuals and some occur in communities having a common ancestry, which are of considerable extent. As a whole, the halophytic flora of the far north is of great economic importance, inasmuch as it constitutes practically all of the forage of this vast region, being thus the basis of the pastoral industry.*

The following species of halophytes were observed on the Copley Plain or on slopes contiguous thereto: Atriplex spongiosum, A. vesicarium, A. quinii, Kochia pyrmidata, $K$. planifolia, $K$. cannoni, $K$. villosa, $K$. decaptera, $K$. eriantha, $K$. sedifolia, Enchylona tomentosa, Bassia lanucuspis, B. paradoxa, and Salicornia tenuis. In addition, "salt-loving" species of other families were found, among which were

* In 1912 the Central, Lower North, and Upper North of South Australia supported the following number of live stock: cattle, 199,727; horses, 197,139; sheep, 2,674,856 (Handbook of South Australia, 1914, p. 143); there are also several thousand camels. Besides the domestic animals which derive their entire subsistence from the native flora, there should be mentioned the native and introduced wild animals which also subsist wholly on it. Of these, the most destructive are the rabbits. They occur during favorable periods in countless numbers and work great harm to a very wide class of vegetation, including that useful to sheep, oattle, horses, and camels. 
Nitraria schoberi, Zygophyllum crenatum, Z. fruticulosum, and Z. prismatothecum.*

The vegetation of the Copley Plain at present is very sparse, in places wanting, but in some places it is fairly abundant. Where absent, as on the higher portions, the dead stumps of shrubs show that in former times it also was covered by plant growth. But in a few small basins without surface outlet, where there is an excessive accumulation of salts, the edaphic conditions do not now and have not in recent times permitted the presence of plants. On the lower and also well-drained parts of the plain, on the other hand, species of Atriplex and of Kochia especially occur in good size and fair abundance. Plate $7 \mathrm{C}$ shows their leading characteristics. In order to learn the density of the population of saltbushes, a census was taken at the base of Table Mountain, about a mile south of Copley, at the upper limits of the plain where it joins the slope of the hill. Here were Atriplex and Kochia, with some specimens of a small and undetermined grass, a geranium, and a mustard. The area observed measured 10 meters square. In the first square 40 shrubs were counted, of which 36 were Atriplex. In the second square, somewhat nearer the hill, 42 shrubs were found, of which Zygophyllum fruticulosum was the dominant form, the balance being Salicornia and Kochia. Plate 8A shows the character of the plants and of the habitat. Somewhat farther (possibly 200 meters) on the plain and well away from the slope, Salicornia tenuis was dominant, with Zygophyllum present in fewer numbers than in the second square. At this place there were relatively large areas quite bare of halophytes other than Nitraria schœberi, which was growing on sandy hillocks. On the surrounding ground, where no perennials were found, there was a very dense covering of very small plants. These were mainly an annual species of Atriplex, which was largely in fruit. In such an area, 1 square meter, 1,200 individuals were enumerated.

One of the characteristic features of the halophytic flora of the plain is the frequent occurrence of such forms on hillocks of various sizes, mostly small, which have been built up around them through wind action. Such hillocks were observed in connection with species of Zygophyllum, Atriplex, Kochia, and Nitraria. In the first three instances the result seems to be mainly incidental to the interference with the wind flotation of the sand, but in the last case there is a nice accommodation to the heaping sand on the part of the plant which merits some attention.

Nitraria schoberi is a low shrub of rather diffuse habit. The branchlets are often spinose and rigid. The habit and habitat of the plant

* The three species of $Z$ ygophyllum, it should be noted, are included here doubtfully. They occur characteristically on slopes, but also were found at the edge of the salt plain; hence their inclusion among the halophytes. It should also be said that certain species of Kochia especially occur where the soil does not appear to carry an excess of salts. In general this study does not undertake to distinguish between the species as to their toleration for salts. 
are shown in plate 8B. At the climax of its development a typical Nitraria hillock measures about 3 by 13 meters in horizontal plan. The height rarely exceeds 1.5 meters and is usually somewhat less.

The origin and growth of a hillock, mound, or dune seems to be about as follows: In its earlier condition the seedling Nitraria has a wellmarked main stem with branches fairly well raised from the surface of the ground. In this stage it does not interrupt the movement of the drifting soil. Early in its development, however, the lower branches come to lie on the surface of the ground and thus provide an obstruction to free movement of the sand. The result is that such horizontally disposed branches become covered by soil; they develop roots and send up shoots which in growing maintain their position above the accumulating sand drift. Thus the plant adds to its size on every side; the central portion grows actively and keeps above the surface of the accumulating soil, and the characteristic hillock, ever increasing in diameter and height, results.

The long diameter of the mounds seems to be usually at right angles to the direction of the prevailing wind, southeast and northwest, although there may be exceptions to this. The "runners" which extend the hillock colony, as well as characteristic features of such a colony, are shown in plate $8 \mathrm{c}$.

When the maximum size has been attained the hillock begins to break up in the following way: Portions of the plant which are about centrally located die out, for various reasons, and the soil about them begins to be removed, or possibly the converse is the initial step. However this may be, the soil placed in the midst of the dune is gradually removed by wind action until the original level has been attaineda process of "base-leveling" - and the two ends are completely separated. Thus two daughter mounds ultimately result in the natural course of disintegration of any Nitraria dune.

From observations on the character of the flora which occurs on and around the base of a Nitraria mound, it seems probable that the accumulated soil of the hillock does not carry the large amount of salts found in the soil characteristic of the plain proper. Thus a greater proportion of nonhalophytic annual growth is found on the hillocks than on the lower contiguous ground.

\section{Root-Habits of Plants of the Plains.}

The roots of typical annuals and of a few perennials (halophytes) which were growing on the lowlands in the vicinity of Copley were examined. The depth of soil in all cases was greater than the depth attained by the roots, so that the maximum penetration took place. The roots of the perennials were for the most part studied along washes where they had been exposed, although in a few instances they were examined remote from drainage channels of whatever sort. The roots of annuals were seen on the open plain, but mostly where diminutive 
hollows made possible relatively favorable water conditions, with results which can be briefly given.

In one place the roots of several annuals, mainly of species I did not know, were examined. The shoots were 2 to $7 \mathrm{~cm}$. long and for the most part either in flower or in fruit, and therefore fully matured specimens. A cruciferous species had a tap-root which varied in length from 4 to $8 \mathrm{~cm}$. Another species, with a rosette, had a prominent tap-root 7 to $9 \mathrm{~cm}$. long. Of all the annuals seen at this place none had roots which penetrated over $12 \mathrm{~cm}$.

In another locality, about 2 miles east of Copley, but on a sloping plain, the roots of several annuals were dug up. Among these were several specimens of Zygophyllum crenatum. In specimen $a$ the shoot consisted of 4 leaves and was $6 \mathrm{~cm}$. long, and the tap-root was found to be $8 \mathrm{~cm}$. in length. It was little branched. In specimen $b$ the shoot bore 6 short leaves and was $4 \mathrm{~cm}$. in length. The tap-root was over $13.5 \mathrm{~cm}$. long. Specimen $c$ had a tap-root over $8.5 \mathrm{~cm}$. in length.

Roots of Geranium pilosum, which is one of the most common annuals on the plain, and which was growing abundantly near the Zygophyllum, were also examined. In specimen $a$ the small rosette had 7 leaves and flowers had been formed. The leading root was a tap-root, but this bore numerous fine laterals. It penetrated to a depth of more than $8.5 \mathrm{~cm}$. In specimen $b$ the shoot was somewhat larger and the taproot was traced to a depth of over $11 \mathrm{~cm}$. In another situation, where the plain was in part bare but where there were also slight and inconspicuous hollows, there was a sparse growth of annuals. These were of various species, including an undetermined grass about $3 \mathrm{~cm}$. high, a species of Geranium, a Zygophyllum, and some crucifers. As a rule the shoots of the annuals, which were fully matured, did not exceed $4 \mathrm{~cm}$. in height. Although there was found to be a certain specific difference in the root-systems of these plants, it was learned that in no case did the penetration exceed $13 \mathrm{~cm}$. and it was mostly less. In the case of the Zygophyllum, prominent laterals $8 \mathrm{~cm}$. long, more or less, were found.

As a result of the observations on the winter annuals of the Copley Plain, it can be said that, even under such relatively favorable local water relations, the roots do not penetrate the ground over 10 to 13 $\mathrm{cm}$. and for the most part they lie closer to the surface than this.

The roots of species of Atriplex and of Kochia, which were also situated on the Copley Plain, were examined in several specimens, and a certain parallelism in development was noted, similar to the development of the root-systems of most perennials, other than halophytes, which were seen. One of the features of the plain referred to is the presence of various dead perennials, mainly halophytes. Whatever may have been the cause of the death of the plants, it was noted that the root-system remained almost intact. The roots of 
such dead specimens had certain points of interest. It was found that soil no longer remained around the base of the halophyte when dead as it does around the living plant, but it is removed from the root-crown, exposing the origins of the superficialroots very completely. In every instance the dead root-crown is surrounded by a radiating circle of small roots which start away in a fairly horizontal direction. In one plant of undetermined species, where the superficial roots were exposed in the manner indicated, 23 were counted, all very close to the surface, but 3 or 4 were found more deeply placed.

Living plants mostly were studied and the results, as above suggested, were very uniform. A Kochia which was growing on the plain at some distance from any wash was carefully removed from the ground. A tap-root which penetrated $39 \mathrm{~cm}$. into the soil was seen to be fairly moist. All of the laterals, of which there were several, arose at a depth of about $10 \mathrm{~cm}$. from the surface and were traced more than $60 \mathrm{~cm}$. from their place of origin. A species of Atriplex, situated by the side of a small wash and not far from the Kochia just mentioned, was found to have a prominent tap-root and prominent laterals which ran in a fairly horizontal direction, and not far beneath the surface. A species of Salicornia, growing close by, had a root which penetrated to a depth of $15 \mathrm{~cm}$. and then, turning sharply, ran horizontally. Several large horizontal roots arose within $10 \mathrm{~cm}$. of the surface of the ground and many small laterals took their origin at about half that depth. So far as this species is concerned, therefore, the laterals constitute a very prominent feature of the root-system as a whole. That a recent rain of 0.21 inch penetrated to the roots of this species was evident from the fact that the branches and leaves were turgid.

Of the root exposures, however, the best were found along a recent wash to the north of Table Mountain, where a small box canyon, about 100 meters in length by half that width, had been eroded. The sides were vertical and the walls about 1.2 meters high. The wash ran through a small plain on which were Atriplex and Kochia mainly, with Atriplex sp. dominant. The roots of several plants were partly exposed and were observed. Since the roots of all were about the same, a description of those of one will be sufficient. In this specimen the shoot was only in part living and it was apparent that a portion had been removed. Of the roots, it was found that 3 fairly large ones, representing tap-roots, went straight down over 1 meter. Several took their origin from these vertical roots just beneath the surface of the soil and ran in a horizontal direction, about $2 \mathrm{~cm}$. beneath the surface, to the base of a neighboring Atriplex, about 1.5 meter distant. The vertical roots gave off small and relatively unimportant branches at a depth of about $30 \mathrm{~cm}$. The superficial horizontal roots bore numerous filamentous roots and such roots were seen on the most superficial of the other laterals. Such filamentous roots correspond to the "deciduous" 
rootlets which have been seen to occur on similarly placed superficial laterals of several species in the Tucson, Arizona, region.

The roots of perennials growing on the Copley Plain, and described in the foregoing paragraph, are all either sharply vertical or as sharply horizontal in position. It is probable, from the large number of observations, that this is the usual condition. However, an exception was found by a wash on the edge of the plain, where the soil is fairly coarse and the bank is about 2 meters high. Here an undetermined halophytic shrub of small stature had a root-system which was unlike that above described. In this instance there was a brush of roots, without the sharp differentiation into the vertical and horizontal members as elsewhere observed. This condition is probably attributable to the fact that the soil at the place is relatively coarse, permitting a deeper penetration of the rain and better conditions of aeration than would more commonly be the case.

\section{Vegetation of the Low Hills and Slopes.}

The lower hills and slopes and the slopes of the higher hills are usually well covered with a perennial vegetation. Although some of it is of the halophytic type, it is largely composed of sclerophyllous shrubs, fairly uniform in appearance and generally of a relatively small size. The hill vegetation is so varied in species that it would require a much closer study than the present one to describe it at all accurately, as well as the aid of a large-scale contour map showing the leading geological features. Such, unfortunately, appears to be wanting. Certain leading characteristics, however, can be presented as a preliminary study. Possibly the most striking single feature of the hill perennial flora is the frequent segregation of species, so that a relatively large area may be populated by a single one to the exclusion of all others. This was noted again and again. Although there are many species of perennial habit on the hills, it is probably true that the most typical belong to two genera, Cassia and Eremophila. It will therefore probably convey the right impression if the vegetation of the hills was defined as the Cassia-Eremophila community. Following are some of the most conspicuous species of the low hills and slopes:

Eremophila brownii.

E. freelingii.

E. oppositifolia (plate 8c).

E. latrobei.

Zygophyllum fruticulosum.

Z. crenatum.

Z. prismatothecum.

Pholidia scoparia.

Fusanus acuminatus.

F. spicatus.
Eucalyptus oleosa.

Cassia eremophila.

C. sturtii.

Myoporum platycarpum.

Acacia sentis.

A. aneura.

Cheilanthes tenuifolia.

Kochia planifolia.

K. sedifolia.

Euchylæna tomentosa.
Atriplex vesicarium.

Bassia lanicuspis.

Hakea leucoptera.

Nicotiana suaveolens.

Petalostylis labicheoides.

Solanum illipticum.

Menkea australis.

Pimelea microcephala.

Trichinium incanum.

Casuarina lepidophloia. 


\section{Mono-Specific Communities.}

Although the hill-slope habitat is here treated as a single unit, it is nevertheless far from uniform. However, as this habitat is well drained and hence the soil is well aerated, with relatively good water relations and various aspects, it may be proper to group the different slopes into one habitat. One of the features of the habitat is that any one element, for example the slope of a hill, is cf relatively large area, so that the environmental conditions of the particular area are correspondingly of relatively wide extent. This uniformity of environmental conditions extending over a relatively wide area is doubtless responsible for the frequent occurrence of a single species only, particularly of perennials, thoughout such an area. Thus it happens that monospecific communities are common in the Copley region. Some of these will be mentioned here. The most conspicuous are those of various species of Eremophila. Of these, the ones along or accessible from the Mount Serles road may be considered typical and need only be described.

To the east of the village the Copley Plain pushes into the hills, forming a bay-like area, with hills to the south, ending at the west in Table Mountain and lower hills on the north. The plain rises about 1.5 miles from the village and insensibly merges into gentle slopes which descend from the hills on the south. At the place in mind there is a considerable outcropping of slate or shale. With its northern aspect. the habitat is relatively warm and is subject to the north winds, which at times are hot and dry. On this slope occurs Eremophila freelingii, solely among perennials. This is a shrub about 1.5 meters in height, with an open habit of growth. The leaves are numerous and fairly crowded towards the ends of the branches (plate $9 \mathrm{~A}$ ). They are of leathery texture, about $3 \mathrm{~cm}$. in length, and somewhat viscid. In the middle of July, when the area was first studied, they bore large numbers of lavender-colored flowers. No measurements were made nor computations of the populations per unit area. It can be seen from plate $10 \mathrm{~B}$, however, that the shrubs occur but sparsely. Another area, in which $E$. freelingii occurs to the exclusion of other species of perennials, is by the Mount Serle road and about 5 miles east of Copley. Here are rounded slate hills also and the conditions are otherwise much as at the habitat just described (plate 9c).

An additional mono-specific community observed was that of Pholidia (formerly Eremophila) scoparia, which was not far from the habitat last mentioned. It was different, however, in that the slope has a southern aspect and is somewhat lfss steep. Probably the water conditions are somewhat more favorable. Pholidia scoparia is rather strict in habit, "broom-like," in fact, and has small leaves closely appressed to the branches, as shown in plate 9c. The shrubs have a canopy top and are 1.5 to 2 meters in height. Where they constitute 
the sole species, as at the habitat mentioned, they form one of the mcst striking communities of the whole region (plate 10c).

A mono-specific community of quite a different character was observed on the upper slopes of hills leading up to the eastern summits of the Mount Deception Range, about 4 miles to the west of Copley. When viewed from the plain, there appeared at this place a brightgreen area, as of a grassy field. When it was reached, however, by the way of the lower hills, it was found to consist wholly of Zygophyllum crenatum, a low, spreading annual. There was no other species of any sort over the rather large area, possibly of several acres.

Among other species, which occur in large numbers to the exclusion of others, is Cassia sturtii. This is a somewhat diffuse shrub about 1.5 meters high. It appears to have been much more abundant in former times in the vicinity of Copley, if one can judge from the large areas which now are covered with specimens no longer living, as on certain slopes of the Mount Deception Range. At present, however, it is common enough. Frequently, as among the rounded hills along the Mount Serles road about 5 miles east of the village, it forms fairly large communities (plate 10A). It seems to be restricted to hills and slopes.

Another example of a mono-specific community is that of Kochia sedifolia, which, unlike so many of the family, appears not to tolerate a large amount of salts in the soil, so that possibly it may not be considered a strict halophyte. It occurs on slopes which are often, but not always, somewhat above the plain. The situation of the habitat to be described is along the Yudnamutana road, about 2 miles northeast of Copley, where an intermittent stream, making its way across a slope from hills farther east, has cut a fairly deep gorge. To the south of the edge of the latter the slope dips gently to the Copley Plain. The population is fairly sparse, as the habitat shows (plate $7 \mathrm{c}$ ). The individuals are about $50 \mathrm{~cm}$. high and of a very close, compact growthhabit. The species occurs to the exclusion of others over an area many acres in extent.

Zygophyllum fruticulosum is another species which may occur solely in a habitat. This small shrub, of a lax growth-habit, grows on the lower slopes of the Mount of Light as well as on nearby slopes to the exclusion of other species of perennials. The habit and distribution of the species, as well as the character of the habitat, are fairly well shown in plate $11 \mathrm{c}$.

An additional species, which occurs with little or possibly no ad mixture of other species in certain areas, is Eucalyptus oleosa. This is one of the "mallees." Although the mallee does not form a conspicuous member of the plant community at Copley, it is to be found scattered along the washes, and at a place about 4 miles west of the village and in the Mount Deception Range a mallee thicket has 
been formed. The species has a heavy root-crown and a thickened stem-base, from which numerous branches arise. The entire aspect of the species is shrub-like, with the "canopy" top so common among Australian shrubs and trees.

\section{Isolated Species and Mixed Communities.}

Should the vegetation of the Copley region be studied from the standpoint of its distribution, it would be found that all gradations exist between the mono-specific communities above sketched and geographically isolated individuals. As a matter of fact, possibly most of the species occur mingled in this manner. Whether such small communities or isolated individuals represent recent introductions or survivals from populous mixed communities are matters of interest, but this study throws no light on the problem. It is evident that the controlling factor of the hill-slope flora is the single one of moisture and that it is apparently a fortuitous mingling of mostly unrelated elements. This is in sharp contrast to the flora of many species of the Copley plain, which is bound by edaphic ties. In other words, the conditions noted are the usual ones controlling the plant distribution in an arid or semi-arid region.

It is not especially unusual to find a single species of woody perennials represented in any area by one specimen only. For example, one or two specimens only of Hakea leucoptera occur on the top of Table Mountain (plate $11 \mathrm{~A}$ ), although there is a small colony of about 20 widely separated individuals on low slopes at the head of a draw at the east base of Mount Deception Range west of Copley. It was not seen apart from these two situations. At Copley the species has the habit of a small tree, about 5 meters high, with a pronounced canopyshaped crown. The leaves are needle-like (plate 12D) and the whole appearance of the species is as one well adjusted to very arid conditions. It is one of the species which has probably suffered little by the advent of the white man and his varied activities. It is not eaten by his animals or used by him as a fuel. For these reasons the occurrence of the species as to its distribution in the Copley region probably represents its reaction to the physical environment only. Such a remark might also be made regarding smaller woody perennials, as the Eremophilas and Cassias.

Another woody perennial which occurs sparingly is Petalostylis labicheoides. This species was found at the south and west base of Table Mountain, in a straggling group or two of few individuals. It was seen in no other place. The shrub has a very striking appearance, but imperfectly shown in plate 12, A and c. Several branches of approximately equal length are fairly well clothed with compound leaves which carry 15 to 31 leaflets. Thus the leaf-area is large, although the leaflets are rather small. 
Among other species of the hill-slope habitat which occur rarely or scatteringly, mention need be made of two or three additional ones only. Thus, Cheilanthes tenuifolia was found only among rocks, south surfaces, on the northern slope of Table Mountain. Casuarina lepidophloia occurs in small numbers around the south and west base of Table Mountain (plates 11B and 12B), and also in few numbers among the low hills on the Mount Serles road. In other places, as on the top of Table Mountain, the species occurs sparingly. This species forms a small tree in the vicinity of Copley and is of some economic use, making it probable that the number of individuals is very much less now than in earlier times. It is to be questioned, however, whether it ever occurred so abundantly at Copley as to constitute a pure community, as at Quorn, for example.

An additional species which occurs but sparingly at Copley is Pimelea microcephala. Two specimens of this small shrub were found at the eastern base of the Mount Deception Range and in the same habitat as Hakea leucoptera. It occurs in certain other places also, as to the south of Table Mountain.

\section{Vegetation of the Washes.}

There is no sharp distinction between the plants of the hill-slope habitat and that of either the plain or of other portions of lowlands, provided the drainage is good. Thus there are lines of stress between contiguous habitats where the species most characteristic of each are more or less mingled. Some instances of invasion may be found, but these appear to be rather uncommon. Inasmuch as the water relations of the washes of whatever kind are particularly favorable, this fact is reflected in the vegetation growing in them. Thus, species with large water requirements may be found in such a habitat, and as a general thing, although not without exceptions, such forms have a relatively large transpiring surface, may be of good size, and may occur in abundance.

One of the most characteristic trees of the washes is the red gum, Eucalyptus rostrata. This becomes a fair-sized tree whose habit of growth is illustrated in plate 13c. In places, as on Leigh's Creek near Copley, the red gum is confined to the floor of the wash. Here the bank is about 5 meters high and has all of the physical characteristics of the plain of which it is a part. Somewhat farther up the same wash, however, the transition from flood-plain to the adjacent higher ground is gradual and the plant communities characteristic of wash and plain are more or less mingled. Smaller contributing washes, whose depth may be little if any over a meter and whose width may be no greater, also carry the species. Such small washes are marked by a "single file" of the gums crossing the plain. The same wash entering the hills to the east of Copley is, with its smaller branches, likewise populated with the gums. It is apparent, therefore, that the species is very 
closely and directly dependent on a relatively good water-supply. It would be impossible to judge the earlier distribution and frequency of the species from its occurrence at present, owing to the past as well as the present demands of the white population for its use in various domestic purposes. However that may be, owing to the close dependence of the species on a good water-supply and to its not being very tolerant of an excess of salts in the soil solution, and, further, owing to the fact that the physiographic conditions are by and of themselves much restricted, it is hardly to be supposed that the species at any time had a distribution different from what it has now, even if the number of individuals may have been greater.

Among the other woody perennials found in and along the washes are Melaleuca glomerata and $M$. parviflora. Although these species are confined to the washes, they are not generally distributed along them, as is the case of the red gum, but are segregated into isolated masses. Both species, for example, are to be found on the floodplain of Leigh's Creek at a place near the Myrtle Springs road and about 2 miles from Copley, and also in a small wash not far from the Yudnamutana road, about 3 miles north of the town. $M$. parviflora is a small tree (plates 13B and 15A) and is said to be tolerant of an excess of salts in the soil solution, and thus to be an "indicator" of brackish water. M. glomerata, on the other hand, is said to be an "indicator" of fresh water. However that may be, the two species are closely associated in the two habitats above referred to. $M$. glomerata is a large shrub (plates 13A and 15D) and under conditions such as occur along the Myrtle Springs road may form a dense, jungle-like growth with semi-prostrate stems, unique in this regard and different from most species of a semi-arid region. In both species the leaves are small, almost needle-like, but numerous, and hence the transpiration surface of any individual is large.

Of other species belonging to the washes, there may be mentioned certain Eremophilas, some of which are wholly confined to drainage channels. Of these, the most pronounced, so far as the characteristic just mentioned is concerned, is $E$. alternifolia (plate $14 \mathrm{~A}$ ). Whenever in the Copley vicinity an Eremophila was found along a drainage channel, however small, as a slight depression on a slope, it was nearly always of this species. In spite of the fact that (as plate 15B shows) the leaves are fairly small, it seems necessary for the species to have much better water relations than any other of the genus occurring in this vicinity. Eremophila latrobei is a small tree; it was found in a small wash near the Yudnamutana road and nowhere else. Eremophila longifolia occurs in the same locality and elsewhere, but is not common. It also is a small tree. The habit of the species and of the leaf is shown in plates $14 \mathrm{~B}$ and $16 \mathrm{~A}$. 
Of other species found only in or along washes, Acacia varians, "native willow," becomes a fairly large tree with drooping willow-like habit (plate 15c). This species does not appear to be very common. $A$. sentis and $A$. tetragonophylla are confined to bottoms by drainage channels, or to such channels. The former is not abundant, but the latter forms small thickets which are nearly impenetrable, hence the local name "dead finish," not alone because of the abundance of the individuals, but also because of the short and sharply pointed phyllodia (plate 16, B and c). Casuarina lepidophloia occurs along bottoms contiguous to washes not far from the one along which Acacia varians was found. Senecio magnificus occurs only where the water relations are relatively good, as in or along washes.

Of other species confined to washes, or to their immediate vicinity, Heterodendrum olecefolium, Myoporum platycarpum (plate 17B), and Jasminum lineare, all small trees, may be mentioned. Although the leaves of all are relatively large, those of the first named are the largest and, as will appear below, possibly rank next to those of Eucalyptus oleosa in size, indicative of an adjustment to relatively favorable water conditions.

\section{Parasitic Phanerogams.}

The flowering parasites constitute a very conspicuous portion of flora of the Copley region. They represent two families, the Loranthaceæ and the Santalaceæ. Of the former, Loranthus exocarpi, $L$. linearifolius, and L. quandang, and of the latter family, Fusanus acuminatus and $F$. spicatus were seen. The mistletoes are of very general occurrence, but the sandal-woods occur much more sparsely.

Loranthus exocarpi is the most commonly met of the mistletoes. It is to be found on a relatively large number of hosts, among which were seen Eremophila brownii (plate 17D), E. longifolia, Fusanus acuminatus, Acacia sentis (plate 17c), Melaleuca glomerata, and Myoporum platycarpum (plate 18c). Loranthus linearifolius was found on Acacia tetragonophylla (plate 18B), and L. quandang was seen on Acacia aneura. Of these species, only $L$. exocarpi on Eremophila longifolia and $L$. quandang on Acacia aneura (plate 18A), the "mulga," were seen to be in harmful abundance. In the latter instance, especially, the parasitic relation is said to terminate fatally for the host in every instance and within two years or more following infection. A striking peculiarity of the leaves of certain of the parasitic couples is the strong superficial resemblance which they hold.

The sandal-woods are small evergreen trees and occur rather sparingly in the hill-slope habitat and apparently nowhere else. The fewness in the number of individuals is in part attributable to demands of various kinds which are made on them. They are a source of fuel and also are attacked by animals which devour the young branches and leaves. The fruits of one of them, the "native peach," F. acuminatus, are used as food to a certain extent by dwellers in the region. 


\section{Root-Habits of Plants of the Washes.}

A few root exposures were found along different washes, where the erosion of the soil left them more or less in place. The leading results of the observations on them can be briefly given.

Pholidia scoparia has a large development of roots which take their origin near the surface of the soil, and at less than 1 meter from the main root they attain to a depth of approximately $40 \mathrm{~cm}$. and maintain this depth for an undetermined distance. There also is a well-marked tap-root. Essentially the same condition was seen in Eremophila freelingii, which was growing on the edge of a wash whose bank was over 3 meters high. In this case, however, numerous radiating roots were seen and no tap-root. The roots of unknown shrubs which were growing along a smaller wash had roots of the same general type as that given above for Pholidia. An undetermined species of Acacia was found to have two prominent roots which were superficially placed; the balance of the roots were not seen. The most deeply penetrating tap-toot found was of an unknown Atriplex, which went to a depth of about 2 meters. This species also had roots horizontally placed. By a wash leading down from the Mount Deception Range there is a small straggling grove of Eucalyptus oleosa where a few roots are exposed. As the bank was not a high one the exposure was not extensive. It showed, however, the swollen stem-base and enlarged root-crown, "mallee" characters, and the origin of the main roots (plate 19в).

It appears from these observations that the root-systems of perennials of the washes and hill-slopes, with the possible exception of that of Pholidia scoparia, consist of a deeply penetrating portion and a superficial portion which extend in a horizontal direction. Obligate deeply penetrating or obligate superficial root-systems probably do not occur.

\section{Leaf-Form and LEaf-Sizes.}

The leaves of all of the perennials observed at Copley are coriaceous, and although they vary considerably in size they have a certain monotony in outline. A few of the species have linear leaves, or phyllodia, and these may be greatly elongated or they may be short and almost spine-like. The widest as well as the longest leaves were those of Eucalyptus rostrata, which may be characterized as being narrow elongate. Thus, except for the juvenile leaves of this species, there appears to be no perennial in the region with leaves that are even ovate, not to mention the wider possible forms.

A detailed account of the sizes and forms of leaves will be given in a separate section. Here it will be sufficient to present a summary showing the relative sizes of the leaves of several different species. The leaves of Eremophila alternifolia are given a value of 1 ; from this as the base, the relative size (area) of the leaves of several species is as follows: Acacia aneura, 1.3; Eremophila brownii, 2; Myoporum platycar- 
pum, 5; Fusanus acuminatus, 7; Fusanus spicatus, 13; Acacia varians, 15; Eucalyptus rostrata, 20 to 26 . As this is a portion only of the species observed, no safe conclusion can be drawn from the relation above them. It is of interest to note the relatively large leaf-area of Eucalyptus rostrata and Acacia varians, which are strictly confined to the habitat of the washes. But the complete exposition of leaf-sizes of such a habitat as the wash, however, would show great variation. Thus Eremophila alternifolia is confined, and quite strictly so, to this habitat, and it has the smallest leaves measured. It should be said, in this connection, that a great reduction in the transpiring surface, even to a condition of total aphylly, is not uncommon in species with large water-requirement. The opposite condition, however, namely, the occurrence of large-leaved species in $d r y$ habitats, does not take place. Therefore, the general rule can probably be said to hold, that there is a direct relation between leaf-size (or transpiration surface) and water-relation, at least in an arid region such as that about Copley.

\section{VEGETATION OF SOUTHWESTERN SOUTH AUSTRALIA.}

In the brief discussion to follow, on the plants of the southwestern portion of the state and on their environment, the vegetation of only three stations along the line of the trans-Australian railway will be considered, namely, Port Augusta at the head of Spencer's Gulf, Ooldea not far from the western border, and Tarcoola about halfway between the two. At Port Augusta the rainfall is about 10 inches annually and at the other stations it is somewhat less. Port Augusta is at sea-level, but Ooldea and Tarcoola each have an altitude of about 500 feet. In spite of the low topography and the small rainfall the region is much more varied and interesting than at first might be supposed. At the extreme west and extreme east are plains, and in the mid-region low hills characterize the topography. Except for the outcrops of pre-Cambrian rocks, of relatively small area, the region is of the Cenozoic age; Recent to Pleistocene between Port Augusta and Ooldea; and Miocene and Eocene west of Ooldea. With a single exception, therefore, this portion of South Australia is geologically much more recent than the far north. In the plains regions halophytes are the dominating plants, and in the hilly mid-region there is a large variety of species which occur in larger numbers than might be supposed, judging from the rainfall alone. They all, however, reflect the severity of the environmental conditions under which they and their ancestors have developed for an immense period of time.

\section{VEGETATION AND THE ENVIRONMENT AT OOLDEA.}

\section{Physiography.}

Ooldea is a station, really a construction camp at the time of my visit, on the new railway crossing the continent, and lies about onethird of the distance between Port Augusta on the east and Perth on 
the west. It is 427 miles from Port Augusta and about 80 miles, in a direct line, from the Great Australian Bight. The main features of physiographical interest are the sandhills to the east and the Nullarbor Plain on the west. It lies thus at the division between the two.

The Nullarbor Plain is a formation of very great interest and uniqueness. Its east-west extent is about 450 miles and its north-south extent about 200 miles. The plain is a sea-floor, of the Mesozoic age, underlain by Paleozoic rocks (Jutson, 1914:71). Rocks of the same age outcrop to the west of the plain in Western Australia, and passing beneath the plain appear again about 100 miles to the east and again at intervals farther toward Port Augusta, as at Tarcoola. The Nullarbor Plain is composed of limestone of a thickness approximating 500 feet. The surface of the plain is nearly level, as would appear from the fact that the transcontinental railway runs for 330 miles, nearly across it, without a curve. The topography, however, is not absolutely flat, but is very gently rolling and dips (less than 1 foot to the mile) to the east. The limestone is covered by about a foot of red soil, although fragments of the underlying rock are scattered about on the surface.

The most striking feature of the plain, however, aside from its level character and great extent, is the presence here and there of slight depressions, known as "dongas," which vary in size from a few to hundreds of acres. There are, in addition, as would be expected in the limestone country, various fissures or openings of various shapes and sizes which communicate with subterranean cavities. Such openings are locally known as "blow holes" from the air-movements associated with them. The "blow holes" often appear to be situated in depressions of small extent. From the structure of the plain it will be seen that such water as falls on it must quickly disappear from the surface. The soil is so thin that it constitutes a very inadequate water-reservoir. In the dongas, however, there is a greater accumulation of soil and hence greater possibilities in the way of water-storage, and in such situations the vegetation is relatively abundant and wholly unlike that of the surrounding plain.

The sandhills region east of the Nullarbor Plain has an east-west extent of 100 miles, more or less, and a larger extent in the northsouth direction. As seen from Ooldea and from the railways traversing it, the region has a certain monotony. The hills are of nearly equal size and run from north to south, or approximately so. A hardpan resembling travertine, or desert limestone, is often present, lying about 1 meter beneath the sandy surface. In the fairly deep hollows between the ridges, however, the sand appears to be deeper than on the ridges themselves. A short distance to the north of Ooldea, where an impervious substratum underlies the hollows, water collects. This may be either brackish or "sweet." Such a place is 
the well-known Ooldea "soak," which has played an important part in the activities of men of all sorts who have been in these parts. Here, in a sandy depression, is to be found a fairly good supply of potable water which appears to be the only water of its kind for a very great distance. Explorers have relied on it for their supply, the aborgines come to it frcm long distances in the course of their wanderings, and it has been an important factor in the construction of the railway, providing good water for camps.

The origin of the sand on the Nullarbor Plain and of the sandhills appears not to be surely known. So far as the sand on the plain in the vicinity of the sandhills is concerned it may have been moved there by wind action from the east, as is popularly supposed. Another hypothesis is to the effect that the Nullarbor Plain was laid down not far from shore and hence that it had a large admixture of coarse material, which was set free upon the elevation and the subsequent erosion of the plain. So far as the origin of the sand in the sandhill region prcper is concerned, Howchin (1909:67) suggests that it may have been derived from the "waste of the granitic rocks, which form the bedrock of the country." The same author says also that the calcareous material, which was derived from "breaking down and solution of Kainozoic limestone, has cemented the sand, in places, into calcareous sandrock, or has laid down from solution a crust of calcareous limestone." Possibly the calcareous core of the sandhills, above noted, had some such origin.

The sandy soil in the Ooldea vicinity is fairly coarse and permits the rapid absorption of water. If, for example, a bucket of water is emptied quickly on level ground it spreads only slightly beyond the place where it is poured and sinks from sight almost immediately. This being the case, it would be expected that water derived from the rains would also sink quickly and without appreciable run-off. Such a condition was observed at the time of a storm of September 14. On this day there fell, between 1 and $4 \mathrm{p}$. m., 0.21 inch of rain. At $4^{\mathrm{h}} 15^{\mathrm{m}} \mathrm{p}$. m. the soil was moist to a depth of $3.5 \mathrm{~cm}$. No rain occurred during the night, but on the following morning the soil was found to be moist to a depth of $9.5 \mathrm{~cm}$. Apparently no run-off had taken place. From these observations, and from the absence of all indications of washing from storms, it is concluded that such water as falls on the sandy soil at Ooldea is absorbed at once, and further, from the nature of the soil itself, that it is well conserved. These conditions must be taken into account when possible reasons for the relatively heavy vegetation of the sandhill region are being sought.

\section{Chimate.}

Ooldea is within the 10 -inch isohyet. It is in the region of winter rains, but apparently more or less precipitation is to be expected in summer as well. It will be of great interest, in view of the fairly abun- 
dant vegetation, to establish not only the amount of rainfall but its distribution through the year. Very little is accurately known as to the rainfall at Ooldea, for the reason that permanent settlement began only with the building of the transcontinental railway, which was opened late in the year 1917. There are, however, records for one year at a railway camp a few miles to the east and for nearly one year at Ooldea itself. In addition, rainfall reports are available for Fowler's Bay to the south and at Tarcoola to the east, covering many years. Nothing is known regarding the rainfall on the Nullarbor Plain except from inference. The precipitation for the years 1917 and 1918 at 396-mile Siding and at Ooldea, supplied by the Bureau of Meteorology of the Commonwealth, is given in table 14.

TABLE 14.-Monthly rainfall at 396-mile Siding and at Ooldea, South Australia, November 1916 to September 1918, inclusive.

\begin{tabular}{|c|c|c|c|c|c|c|c|c|c|c|c|c|}
\hline & Jan. & Feb. & Mar. & Apr. & May. & June. & July. & Aug. & Sept. & Oct. & Nov. & Dec. \\
\hline $\begin{array}{l}\text { 396-mile Siding: } \\
1916 \ldots \ldots \ldots \ldots\end{array}$ & & & & & & & & & & & 0.19 & 0.32 \\
\hline $1917 \ldots \ldots \ldots$ & 2.5 & 1.15 & 1.18 & 1.24 & 0.51 & 1.49 & 1.48 & 0.22 & 0.76 & 1.69 & 1.16 & $\cdots$ \\
\hline $\begin{array}{l}\text { Ooldea: } \\
\quad 1917 \ldots \ldots\end{array}$ & & & & & & & & & & & & 0.73 \\
\hline $1918 \ldots$ & 0.0 & 0.0 & 1.0 & 0.6 & 0.63 & 1.06 & 0.16 & 1.19 & 0.29 & & ..... & ...... \\
\hline
\end{tabular}

No record where ..... is given.

Beyond the general facts that the summers at Ooldea are very hot and the winters are cool, little is known of the temperature. Although 80 miles, or more, intervenes between Ooldea and the sea, it is probable that here, as at Tarcoola, where the distance is even greater, the southern winds are cool in summer and cold in winter, and that the converse is true of the winds from the opposite direction. Such winds, moreover, are undoubtedly of very great importance as factors modifying not alone the temperature but also the relative humidity of the air, and thus they very directly affect the vegetation. This had already been mentioned in the opening section and need not be further dwelt on in this place.

Habitats.

During my short stay at Ooldea, besides exploring on foot its immediate neighborhood, I visited, through the kind assistance of Mr. Edwards, engineer in charge of construction, such localities as were most accessible from camp by motor car (railway), carriage, or saddle-horse. Thus the localities seen included the eastern side of the Nullarbor Plain, the transition between the plain and the sandhills, and the sandhills including the (1) Ooldea Soak, (2) the "oak" forest 6 miles south, (3) the Condensers and Station 408, together with the region traversed between Ooldea and the last two, and (4) the vicinity of Ooldea itself. It will be seen that there are at least three easily 
distinguishable habitats, and probably more-for example, the hollows between the sandy ridges and the dongas on the plain. Study of the plants of these habitats would undoubtedly show that each has a very characteristic vegetation to be associated with the differences which mark each habitat.

\section{Vegetation of the Nullarbor Plain.}

The eastern side of the Nullarbor Plain, as already mentioned, has a very slightly undulating surface. When one is well out on the plain he can see for many miles on all sides. No topographical feature marks one direction as opposed to another. At first there is a sense of barrenness, accentuated by the low relief, which is second only to that to be felt in the region about Oodnadatta; a more careful examination of the plain does not fully justify this impression. A sparse gray-green plant-covering, monotonous in form as well as in color, is to be seen on every side. This is composed of halophytes of various species, among which are chiefly Atriplex vesicarium and Kochia sedifolia. There is also an ephemeral flora composed largely of grasses which spring up after rains; but at the time of my visit (September), only dried remains of such were to be found. These remarks on the flora of the plain apply to the plain proper, or rather to the highest ground, which composes by far the greatest percentage of its surface.

Here and there, in looking about, one sees widely separated masses of green of small extent, really oases, which appear quite like small islands in a dull-gray sea. These are the dongas with their characteristic vegetation. Such dongas as were visited between Watson and Ooldea had a few low trees and shrubs and a fairly considerable dead, herbaceous flora; but the plants, the woody forms especially, appeared to consist of but a small number of species, although so few dongas were seen that no dogmatic statement in this regard would be warranted. Certain of these depressions near the Fowler's Bay road had Acacia tetragonophylla, A. aneura, and a "weeping sandal-wood," possibly Pittosporum phillyrcoides. The kind as well as the abundance of plants in the dongas illustrate in a very striking manner the very great importance of the topography and of the substratum as factors in the vegetation of an arid region. A similar condition is to be found in southern Algeria (Cannon, 1913:31). There, for example, are depressions (dayas) which are the centers of small drainage systems in which there is an accumulation of soil and which have subterranean drainage, so that an excess of salts in the soil solution appears not to occur. Owing in part to drainage into the basins after storms, and in part to the great amount of soil in them, constituting important reservoirs, the dyas and dongas alike have relatively good water relations and their fairly abundant flora follows as a matter of course. 


\section{Vegetation about Ooldea.}

At and about Ooldea, and in fact on all of the sandhills of this region, so far as my observation extended, there is a surprising wealth of woody vegetation. Views across country reveal an undulating surface well covered with low, spreading trees and shrubs. The trees are so numerous that often the branches intermingle, completely hiding the ground beneath. In the immediate vicinity of Ooldea the leading trees and shrubs are species of Acacia, among which the following were seen: Acacia aneura, A. brachystachya, A. colletioides, A. kempeana, $A$. linophylla, A.oswaldii, A.randelliana, A.salicina, and A.tetragonophylla.

The following notes on the local distribution, especially of these species, were made: Acacia aneura, the "mulga," forms a small, fairly dense tree (plate 19A) and occurs in two very distinct forms, that with narrow and that with broad phyllodia (plate 20, B and c). It is fairly abundant at Ooldea. Acacia brachystachya is also common about Ooldea, forming a large and attractive shrub. The phyllodia are linear, long, and, like most of the foliage of the sandhill community, of a gray-green color. Acacia colletioides is common about 6 miles to the south. It is a rather diffuse shrub and bears short spinescent phyllodia (plate 20A). Acacia kempeana, a shrub of compact habit of growth, has a relatively heavy covering of fairly large phyllodia and is common at Ooldea. Acacia linophylla, also common about Ooldea, forms a small tree, possibly 3 to 5 meters in height. In foliage-habit it is quite the same as the same species previously seen at Oodnadatta. Acacia oswaldii, a small tree, was seen about 6 miles south of Ooldea. Acacia randelliana is a shrub, 3 or more meters high, and common about Ooldea. Acacia salicinia, a small tree with rather prominent phyllodia, is frequently seen in the neighborhood. Acacia tetragonophylla, which forms a small tree, was seen only on the edge of the plain and appears not to occur commonly in the sandhills.

With the exceptions noted, the acacias appear to be very generally distributed on the sandhills about Ooldea, but how far they are confined to the ridges was not noted. Among other woody species seen in the same habitat were the "bullock bush," Heterodendrum olecefolium, a small tree well covered with small leaves. Dodoncea attenuata and Olaria muelleri also were fairly common on the sandhills.

Among other species of interest was the "oak," Casuarina lepidophloia, in some respects the most important species of the region. It occurs in the hollows between the ridges to the south of Ooldea as well as on the ridges themselves. The "oak" makes open forests and is said to extend as such to the bight on the south. It is of great importance at present, as the wood is largely used as fuel in distilling water at the "condensers," for uses of the railway in the region. The demand is so heavy for wood that fairly young trees are cut, with serious portent to the species in this portion of the state. 
With other woody species, fairly common, may be included Eucalyptus incrassata var. dumosa. This has the mallee habit of growth and is also utilized as fuel along with the "oak." In distribution this species frequently, if not usually, occurs to the exclusion of other woody forms, but a spinifex, Triodia irritans, is often associated with it. In case, however, other woody species occur with the mallee, the grass seems to be wanting. As to the habit of the mallee, it has open, canopy-like shoots, of many stems, and thus is easily recognizable from a distance. In addition to this, the most abundant of the genus about Ooldea, there are two others of the genus. Of these, Eucalyptus pyriformis occurs very sparingly between Ooldea and Ooldea Soak, 3 miles to the north (plate $21 \mathrm{~A}$ ). The species is of characteristic mallee form, and bears large flowers and fruits (plate 22A). According to Maiden, it is one of the handsomest species of the genus, "because of the large size and showiness of the flowers and the large size and ornamental character or at least grotesqueness of the fruits." The fruits are about $5 \mathrm{~cm}$. in diameter and, occurring in groups, they give a striking appearance to the open shoot. The third species of Eucalyptus seen among the sandhills was a dwarf form, E. leucoxylon var. macrocarpa (plates 21B and 22c). This was seen at Station 408, where it forms a small thicket. It is from 1 to 2 meters high, apparently somewhat smaller than is usual for the variety.

Several woody species were seen only here and there and appeared not to be very common, or at least not to be of very general distribution in the region. Among these may be included Eremophila alternifolia, which is fairly abundant near Ooldea and also occurs on flats between the sandy ridges (Black, 1917). The same author also says that Eremophila paisleyi and Pholidia scoparia are to be found about Ooldea. All of these species of Eremophila were seen at Copley, where $E$. alternifolia is confined to the banks of washes or to other situations where the water conditions are relatively good. Fusanus acuminatus, the "native peach," is not uncommon in the sandhills near the camp. Many other species occur scatteringly, several of considerable interest. Of these, Leptospermum lavigatum var. minus was seen at Ooldea Soak only (plate 22B).

As has been mentioned already, Ooldea Soak is a hollow among the sandhills about 3 miles to the north of the camp. There is more than one depression at the place, but all appear much alike. The higher ground carries a very good population of small trees, acacias and mallee, but in the depressions there is very little growth. It is here that in certain hollows, but not in all, the Leptospermum is to be found. The species is confined to such depressions as have potable water and avoids such as have water that is brackish. It is an interesting fact that, although the water-table of the portion of the soak where the Leptospermum grows is little if any over 1 meter deep, and the water 
itself is perfectly suited to the needs of the sandhills species growing round about, yet they appear never to have encroached on the soak more than they do at present.

Of other isolated species, one of the most curious is the flat-stemmed and leafless Bossica walker (plate 29A). This low shrub forms a small, thicket-like growth. It was seen in several fairly widely separated places, among which was a sandy ridge immediately north of Station 408. At this place, and not far from the Bassioea, there occur a few specimens of a yet more curious shrub, Hakea multilineata. This is a tall shrub with very long coriaceous and strap-like leaves of upright habit (plate 29, B and c). The large and stiff spikes of flowers, "bottle brushes," add to the wierdness of the plant. In the same neighborhood as the two foregoing were Acacia salicina, Callitris verrucosa, Eucalyptus leucoxylon var. macrocarpa, Melaleuca uncinata (plate 29D), and Gravillea stenobotrya. Of these, Callitris, the "pine," is a small tree at the only place, Station 408 , where it was seen.

Gravillea stenobotrya, one of the "beef woods," is a species of considerable interest (plates $24 \mathrm{~A}$ and $25 \mathrm{c}$ ). It becomes a fairly large shrub, 3 meters or more in height, and has a very open habit of growth. The leaves are long and narrow and do not appear to be very abundant. It is thus apparent that the transpiring surface is relatively small. The specimens of the beef wood especially examined were situated on the summit of a sandy ridge at the condensers. A point of special interest in association with the species is its habit of storing water in the roots. It appears that it is one of possibly two woody species of the region (the other is the so-called "water mallee") which does this. Mr. Jay, of the condensers, very kindly demonstrated the roots for me. After removing the surface soil to a depth of approximately $60 \mathrm{~cm}$., several horizontal roots, 3 to $4 \mathrm{~cm}$. in diameter, were laid bare. These were cut into lengths of about $30 \mathrm{~cm}$. and set on end in a bucket. After a few minutes moisture accumulated at the lower ends, but owing to its being at the close of a period of drought not enough water was present to run into the receptacle. The short lengths of root were relatively heavy. When the bark was stripped off, much moisture was found in the region of the cambium. I was informed that at less dry seasons of the year and in more favorable situations at all times, the manipulation of the roots in the manner above described would surely result in sufficient water for drinking.

In addition to the water mallee and the beef wood (perennials), there is the annual "parakeelya," Calandrinia balonensis, which also has the capacity of storing water. At the time of my visit this little species was in flower. It is a low form with numerous very fleshy and rigid leaves. The plants are much sought after by animals which depend on them to a certain extent for their drinking water. They have the ability of retaining their turgescence for a considerable time after removal from the soil, and even if placed in the warm sunshine they wilt only slowly. 
Transition from the Sandhills to the Nullarbor Plain.

Along the eastern edge of the great plain there is at Ooldea a scattered vegetation in which elements from the two physiographic areas mingle to a certain extent. The soil conditions appear to differ from those of the plain in the greater depth of soil brought about probably by drifting of the sand from the adjacent sandhills. Because of this condition the water relations of the transition are somewhat better than they are for the plain as a whole. Here occur, among other species, Kochia sedifolia, which possibly is most numerous; Eremophila alternifolia and possibly other species of Eremophila, Acacia kempeana, $A$. aneura, and $A$. tetragonophylla. A few specimens of Casuarina lepidophloia were seen along the road to Fowler's Bay and Cassia sp. in fairly large numbers. In places rather large areas were covered with dead shrubs which had not been able to withstand the drought of some preceding year; these appeared to be cassias. Finally, there were remains of grasses, species not determined, and among other herbaceous forms, here and there appeared the cheerful flowers of Calandrinia balonensis with its odd fleshy and bright-green leaves.

\section{Leaf-Form aNd Leaf-Size.}

All of the perennials of the Ooldea region have pronounced xerophytic characters, as would be expected from the nature of the environment to which the vegetation is exposed. Without taking up this feature further at this time, attention may be called to the relatively narrow leaves, or phyllodia, of the species. Indeed, it may be said that all species which are not aphyllous bear leaves of this character. The length of the leaves, or phyllodia, averages approximately 20 times the width.

\section{VEGETATION AND ENVIRONMENT AT TARCOOLA.}

Physiography.

Tarcoola is the center of a gold-field of secondary importance and is connected with Wilgena Run, a "station" of about 3,000 square miles, formerly owned by A. J. Cocks esq., of Adelaide, whose knowledge of the region has been generously placed at my disposal and who in various ways very kindly forwarded my studies of the region immediately around the village.

Tarcoola is 257 miles west of Port Augusta and lies 392 feet above the sea. Like Ooldea, it lies on the south edge of the western plateau. The village is about 100 miles, as the crow flies, from the Bight. Between it and Ooldea the country is undulating and about Tarcoola it is hilly. To the east the general level sinks and the flat salt-lakes region begins. At Tarcoola itself the plains between the hills constitute the largest percentage of the surface. The Tarcoola hills, in part at least, are granitic, of pre-Cambrian age, related to the out- 
cropping rocks at Wynbring, west of Tarcoola, and to the ancient rocks to the west of Nullarbor Plain in Western Australia.

The soil in the immediate neighborhood of Tarcoola is various. On the hills it appears to be very coarse and on the adjacent plains there is a large admixture of sand brought from the higher ground. In places there is to be found clay, or at least soil of a very fine character resembling clay, and also a white subsoil, apparently travertine or desert limestone. Some sandy stretches to the north of the village are of very considerable extent; and, finally, there are depressed areas, of various sorts, in which the soil carries a large amount of salts.

With the differences in soil and in topography are associated differences in the water relations as well, and without doubt a close study of the vegetation of the region would reveal a variation in its flora intimately connected with such differences in the subterranean environment.

\section{Rainfall and Temperature.}

The rainfall at Tarcoola averages 7.71 inches over a period covering 9 years, but the variation from year to year is considerable. Thus the highest recorded (1910) was 12.35 and the lowest (1905) was 2.82 inches. The record for Tarcoola in 1912 was 6.43 inches. There were 33 wet days during the year. The wettest month was July, during which 1.8 inches of rain fell. On March 9 of the same year 1.12 inches of rain occurred. The type of rainfall, therefore, conforms to that of the other arid stations visited. In 1912 at Port Augusta 10.92 inches of rain fell during 66 days. It will be seen, therefore, that an average of 0.19 inch occurred each rainy day at Tarcoola and only 0.16 inch at Port Augusta. It is of interest to note that at Oodnadatta the average daily amount during rainy days was 0.15 inch and at Copley (Farina) 0.24 inch. Inasmuch as the penetration of the rains is, other conditions being equal, directly connected with the amount of the rain, it would appear, so far as the year 1912 is concerned, that the rain penetration at Tarcoola was probably fairly, at least relatively, good. About 65 per cent of the rainfall at Tarcoola occurs during the cool season, April to October, while the percentage at Port Augusta is for this season somewhat greater, being approximately 75 per cent.

The summers at Tarcoola are hot and the winters cool, as would be expected from the situation of the place. Mr. Harry Deadman, of Tarcoola, who is well acquainted with its climate, informs me that the summer maximum shade temperature is about $118^{\circ} \mathrm{F}$. The temperature is greatly influenced by the desert-arid region to the north and by the Bight to the south, though the latter is about 100 miles distant. Summer winds from the north are extremely hot as well as dry, while those from the south, in summer, quickly cause a lowering of the temperature. 


\section{Vegetation.}

Views from the low hills at Tarcoola reveal a fairly abundant as well as fairly varied vegetation. As far as the eye can reach shrubs and small trees give the prevailing tone, gray-green, to the landscape, with here and there darker patches of green or lighter masses of gray. There are saltbushes in plenty on the flats and scrub elsewhere. One can identify the dark-green "sandal-wood," the "tea-trees," the "oaks," as well as the "mulga" and "myall." That there is considerable vegetation in the region is further suggested by the fact, as mentioned above, that it constitutes a portion of the Wilgena Run, which at one time supported 30,000 sheep, in addition to numerous cattle and camels.

The habitats examined during my short stay at Tarcoola comprised the low, flat, granitic hills close to town, the slopes of these hills, and the lowlands about them and to the north. In this reconnaissance only the most conspicuous features of the vegetation were taken into account.

The hills appear to be the most arid of all the habitats. This is owing to the coarse character of the soil. We find, accordingly, that the ve etation of the hills is relatively sparse and also that it is of a characteristic markedly xerophytic kind. The slopes of the hills carry the largest number of species as well as the greatest number of individuals. Of the hills' vegetation, the following species constitute a prominent part: Acacia aneura, A. rigens, A.tarculiensis, A. tetragonophylla, Cassia sturtii, Casuarina lepidophloia, Eremophila latrobei, $E$. rotundifolia, $E$. paisleyi, Trichinium incanum, and others.

Acacia aneura, the "mulga," is sparingly abundant on the southern slopes of the granite hill, which for convenience will here be referred to as Gold Hill, from the mining operations carried on, near and southwest of Tarcoola village. It occurs to a certain extent also on other portions of the hill. In and by the side of a shallow wash on the southern side of Gold Hill, in addition to $A$. aneura, are to be found A. tetragonophylla, A. tarculiensis, and Trichinium incanum. The last named, a low, rounded shrub, occurs only sparingly on the southern slope of the hill.

On the eastern side of Gold Hill is a fairly dense population of shrubs, mainly halophytes, of which Kochia decaptera appears to be the most numerous. Here also occur Casuarina lepidophloia and Eremophila rotundifolia, as well as scattering specimens of $E$. ?atrobei and Acacia tarculiensis. Eremophila rotundifolia is a very striking shrub. The shoot is of open habit of growth. The leaves are small, saddle-shaped, and leathery in texture (plate 24B). No species of the genus, seen at Tarcoola or elsewhere, is a more evident xerophyte than this one.

The lower slopes of Gold Hill, where the soil is relatively moist because of seepage, have a fairly abundant perennial flora, much of 
which is halophytic. Thus, on the upper portion of such slopes Kochia sp. is dominant, while below are various species of Atriplex and Bassia. Along the washes one finds Lycium australe and Pimelea microcephala, as well as a few specimens of Acacia rigens (plates 25A and 24c).

On the higher flats, upon which the village is situated, the most conspicuous shrub is Acacia tarculiensis (plate 24D). As the name indicates, Tarcoola is the type habitat of the species. This shrub is 2 meters or less in height, with a shapely shoot, well clothed with phyllodia, which are of fair size and placed in a vertical, upright position on the branchlets. The young phyllodia, at least, are covered with a somewhat sticky substance, possibly resinous, which may be of importance as protection against destructive water-loss. In the same neighborhood and at the time of my visit to Tarcoola in September, there were several species of annuals, but no study of these was made. There was seen a very striking community of "everlastings," which made a dense carpet-like growth, many meters in extent, to the total exclusion of other species of annuals.

Not far to the north of Gold Hill, a second hill, also granitic, was visited. On the south the slope of this hill is fairly abrupt, but on the opposite face it is gradual and merges insensibly with a wide-spreading sandy plain which lies to the north of the village. The vegetation of the hill appears to be about the same as that of Gold Hill, but a view over the plain from the hill shows that the general character of its woody vegetation is rather different from that of the lowlands near Gold Hill, for example. Thus there are trees in some abundance, although not large in size, and numerous shrubs. The plain very evidently carries the largest perennial population of any habitat at Tarcoola. At the north base of the hill in question Acacia tarculiensis is to be found; below and beyond $A$. aneura can be easily recognized, and still further, at the border between plain and hill, is a belt of Myoporum platycarpum; finally there may be seen, scatteringly over the plain, Casuarina lepidophloia. Masses of yellow blazed here and there, where groups of Cassia eremophila were in flower. Between the larger shrubs and trees the blue-green foliage of Kochia decaptera occupied the interstices, like the background of an oriental rug.

When examined more closely, the plain to the north of Tarcoola, or at least its southern portion, is composed of fairly coarse, sandy soil, apparently derived, at least in part, from the disintegration of the hill already mentioned as lying on its south. There was little or no evidence of washing from the rains. It is likely, therefore, that the rainfall mostly penetrates where it falls, so that the maximum benefit to the plants is had. That this is the case is also suggested by the relatively large number of large woody plants, especially of trees, which have survived the destructive influences of man and of animals. The growth-habits of the species of the plain have in the 
main been sufficiently characterized in different parts of this study. It will be sufficient, therefore, to sketch briefly the habits of one not hitherto met, namely, Cassia eremophila. This attractive shrub was in flower at the time of my visit. An especially interesting feature is the character of its leaves. It is one of the few species outside of the acacias which has phyllodia. The leaf is compound, with leaflets about $10 \mathrm{~mm}$. in length. The leaf-stalk is broad, however, and upon the falling of the leaflets it persists in carrying on the photosynthetic function. This is exactly the occurrence in certain species of Acacia, although in some the leaf-forming habit has been lost and phyllodia only are organized.

\section{VEGETATION AND ENVIRONMENT AT PORT AUGUSTA.}

\section{Physiography.}

Port Augusta is situated at the northern termination of Spencer's Gulf. The topography of the region immediately about the place is very diverse. Some of the most striking physiographical features may be briefly described. The head of the gulf, here very narrow, is surrounded by a belt of sandhills, usually of no great height. Back of the dunes, more especially to the north, are depressions which do not have adequate surface drainage, or none at all, and which carry an excess of salts. These are the outlyers of the extensive "lake" district, containing Lake Gairdner, Lake Torrens, and (among others) Lake Lagoon, the latter extending about 200 miles north and west, and somewhat less to the north. To the west and southwest and beginning about 15 miles distant are flat-topped (pre-Cambrian) "tent-hills," remnants of a formerly extensive higher land-level.

The country immediately surrounding the table mountains is somewhat higher than the belt of dunes and salt spots nearer the gulf. Turning to the east we find, beyond the lowlands, western members of the Flinders Ranges extending in a generally north-south direction and distant about 12 miles from the gulf. Between the foothills and the dune-salt-spot region by the gulf are gently sloping plains or bajadas. The mountains are sierras with sharply irregular sky-line, characteristic of the mountains of arid regions. Of the highest peaks, the most important are Mount Brown (altitude 3,500 feet) and Devil's Peak, about as high. It will be seen, therefore, that the situation of Port Augusta, in relation to the mountains and to the gulf, as well as to the vast arid region to the north and west, is such as to give the region climatic conditions, on the whole, unlike those of any of the regions elsewhere met in the course of the present studies. There is also not a little variation in plant conditions because of the differences in altitude and those of aspect, soil, drainage, and moisture which altitude differences entail. 


\section{RAINFALL.}

Port Augusta lies just within the 10 -inch isohyet, having a rainfall of 9.43 inches, the average for 52 years. The greatest rainfall here recorded for one year, up to and including 1912, was 17.52 inches, and the least was 2.21 inches, the ratio thus being nearly 8 to 1 . It is of interest to note that the ratio is about the same as at Copley, but very much greater than at Tarcoola, although the average annual rainfall at all of these places does not vary greatly. The largest proportion of the rain falling at Port Augusta, which amounts to about 75 per cent of the whole, occurs in the cool season. This is approximately 10 per cent less than the rainfall for the corresponding period at Tarcoola and 15 per cent more than Copley. The distribution throughout the year is such as to accentuate the arid conditions for the region, and since rainfall expectancy, the season of its occurrence, and the actual amount are important factors in the aridity of a region, it is seen that Port Augusta must be considered fairly arid.

Temperature.

The climate of Port Augusta is characterized by cool winters and hot summers. The latter, as shown above, are also dry. The mean annual temperature is $66.2^{\circ} \mathrm{F}$., about $1^{\circ}$ less than that of Copley and $2^{\circ}$ less than the mean at Oodnadatta. The absolute maximum (28 years' records) is $117^{\circ}$ and the absolute minimum is $31.4^{\circ}$. The mean number of days in the year having a temperature above $90^{\circ}$ is 67.4 , and the mean number of nights with a temperature under $40^{\circ}$ is 16.6. The monthly course of the temperature at Port Augusta is given in table 7 .

\section{Vegetation.}

The vegetation at and in the neighborhood of Port Augusta, as would be expected from the nature of the physiography of the place, is very diverse, and in earlier, pre-colonial times, must have been fairly abundant. This is indicated not only by the natural flora, but by such introduced plants as have escaped and live under natural conditions, or by such cultivated species as grow without irrigation. Among the latter may be mentioned Schinus molle, which occurs in all parts of the town. The species forms an extensive superficial rootsystem which radiates far from the main stem. Opuntia monocantha also is fairly common and Tamarix crus-gallica occurs about the village. Possibly the most striking introduced plants which reproduce themselves naturally in the Port Augusta region are species of Mesembryanthemum, as $M$. crystallinum, which grow on the sandhills near the coast.

In and close to town several species of shrubs and trees, native to the region, are of interest. In the parks, for example, one finds Acacia rigens and $A$. salicina, and among other species, Nitraria 
schoberi. Among the most striking of the woody perennials to be seen is Avicennia officinalis, which occurs between tides along the gulf. Avicennia, the mangrove, forms fairly dense pigmy forests of narrow width. At high tides the trees are entirely covered with water, and at low tides they are left high and dry on the sandy beach. Radiating from each tree are lines of short shoots which spring from superficial roots. These shoots, usually 10 to $15 \mathrm{~cm}$. in length, appear to develop into the mature form under appropriate conditions, although all have the appearance of being merely pneumatophores. In the zone where they occur the mangroves are the sole species of flowering plants; but farther from the water, although apparently not wholly above the reach of the highest tides, is a belt of Salicornia sp.

In earlier times the low hills, most of which are dunes and lie close to the waters of the gulf at Port Augusta, must have had a fairly dense population of trees and shrubs, if one can judge from the woody plants found in occasional undisturbed places. Among other species, the most striking forms are Acacia rigens and $A$. salicina, as before noted, as well as Casuarina lepidophloia. The shrubs include Nitraria schoberi, Sccevola collaris, Cassia sp., and some halophytes, especially species of Kochia.

Large areas occur where there is an excess of salts in the soil. Here were found species of Atriplex, Bassia, Kochia, Nitraria, and Salicornia, among others.

Upon leaving the dunes and salt spots near the coast, there is a marked change in the character of the vegetation. In the neighborhood of Sterling, for example, numerous specimens of Eucalyptus sp. are scattered about the plain, and along the wash leading away from the mountains is $E$. rostrata. With the increase in altitude as the foothills are crossed the number of individuals becomes greater and the character of the vegetation indicates a larger rainfall. On either side of the highway leading to Saltia, where the foothills spring fairly abruptly from the plain, there is to be found a thick covering of Atriplex and Kochia, and along the lower slopes, near where washes break through, are small thickets of mallee, Eucalyptus oleosa (plate 25в). On the lower slopes of the higher hills, east of Saltia, occur Casuarina lepidophloia, Cassia sturtii, Kochia pyrmidata, Senecio anethifolius, and Eucalyptus odorata. Still farther east and across the high valley east of Saltia are thick forests of mallee, $E$. odorata and $E$.oleosa, and with the mallee were found Geigera parviflora, Dodonaea lobulata, Cassia sturtii, Hakea leucoptera, Pholidia sp., and others. The vegetation along Saltia Creek, including the lowlands on either side, possibly flood-plain, is characterized by trees of good size and in fair abundance. The dominant species by the streamway is Eucalyptus rostrata (plate $26 \mathrm{~A}$ ), and Callitris robusta is also fairly common. With these species there occur a few individuals of Acacia iteaphylla. 


\section{Sizes and Forms of Leaves and Phyllodia.}

Measurements were made of the sizes of the leaves and phyllodia of some of the woody perennials growing about Tarcoola and Port Augusta. It was found that these fall into two well-marked groups, namely, those relatively wide and those relatively long. In the former case the relation of width to length is about 2.2 to 1 , and in the latter it is about 1 to 15.4. The average breadth of the leaves and phyllodia is about $2.8 \mathrm{~mm}$. in the former and $6.8 \mathrm{~mm}$. in the latter. The average length is $42.8 \mathrm{~mm}$. and $14.8 \mathrm{~mm}$. in the two classes of leaves or phyllodia, respectively. The foregoing measurements refer to Tarcoola plants only. So far as those from Port Augusta are concerned, it was found that the narrow type had the following averages: length, 66.3 mm.; breadth, $4.8 \mathrm{~mm}$., giving thus a ratio of length to breadth of about 13.8 to 1 . A noteworthy feature-in the ecology of these plants is that species with narrow type of foliage may occur both along streamways, where the water conditions are relatively good, and also away from the washes, and hence amid more arid surroundings. A more detailed account of the sizes and form, as well as other characters of the foliage of the Port Augusta and Tarcoola plants, appears on pages 111 to 113 .

\section{VEGETATION AND ENVIRONMENT AT QUORN.}

The regions represented in this reconnaissance of the most striking features in the perennial vegetation of the drier portions of South Australia are, according to the terminology here adopted, desert, arid, or semi-arid. Oodnadatta and the Lake Eyre Basin represent the first; Copley and the southwestern portion of the state the second; and Quorn the last. To the latter, however, may be added the mallee region around Blanchtown. There is thus a progressive series so far as the rainfall is concerned. Naturally, and in a manner closely paralleling the increase in rainfall, there is an increase in the amount of vegetation, with a gradual creeping in, as one progresses from the more arid to the less arid regions, of forms less well adapted to withstand the rigors of intense aridity. There is an increase in the number of species as well.

To adequately describe as a whole the flora of any of these regions, not to say those with the greatest rainfall, would be a very serious undertaking. This, as I have already pointed out, is not the object of this study, which aims rather to investigate types of representative plants and their adjustment to the surroundings in which they are to be found. Although I have pointed this out in the introductory portion of the study, it seems well, in order that there can be no misunderstanding, that I refer to it again. This is particularly necessary, inasmuch as the flora at and about Quorn is especially rich and the treatment of it to follow makes no pretense of completeness. 
Quorn is situated about 20 miles to the east of Port Augusta and has an altitude of about 1,000 feet above that place. It is at the junction of the railroad leading to Port Augusta and Western Australia, on the one side, and to Copley, Farina, Maree, William Creek, and Oodnadatta in the far north, on the other. The country between Copley and Quorn, east of Lake Torrens, has many points of interest. Leaving Copley, which is situated in the angle where the Mount Deception Ranges take off from the main masses of the Flinders, the railway goes through a pass with rugged, arid hills on either side and emerges on the Lake Torrens Plain, over which it passes until it nears Hawker. Here it enters more outliers of the Flinders Ranges and, turning, takes a more southwesterly direction, climbing somewhat, and crossing the Willochra Plain, it finally gets to Quorn. For much of the distance from Copley to Quorn, therefore, the picturesque and abrupt western edge of the Flinders parallels the line to the east, while on the west the plain stretches into the haze of the region of Lake Torrens. On the Torrens Plain, halophytes dominate, but species not well adapted to excessive amounts of salts are to be seen following water-courses across the plain. The presence of a fairly abundant vegetation acts to protect the soil for the most part, although in places moderate winds suffice to set it going, much to the discomfort of the traveler, and in high winds the amount of soil so transported must be very great indeed.

In the Flinders Ranges between Copley and Quorn there are relatively high summits, the effect of the altitude of which is accentuated by the western scarp and the sudden rise from the plain. There are interesting formations in the Flinders of this region-for example, the well-known Wilpena Pound, which has resulted from a circumclinal faulting and is accessible from one side only. The mountains here have abundant rains and hence possess rich flora. Species of Eucalyptus are said to attain to large size at and in the region of the pound.

The Willochra Plain, which the railroad crosses just before reaching Quorn, is an alluvial plain formed by delta fans from the mountain washes. It extends from Melrose (to the south of Quorn) to Lake Torrens and is in part subject to inundation from Willochra Creek and its branches. The surface of the plain is fairly level and the run-off following rains is inconsiderable, so that the water soaks into the ground very largely where it falls. The drainage of the plain is through Willochra Creek into Lake Torrens.

Quorn is connected with the plain east of Spencer's Gulf by Pichi Richi Pass, through which the railroad goes to Port Augusta. The altitude of the pass is 1,335 feet and it is about 6 miles to the west of Quorn.

The topography about Quorn is varied and interesting. The altitudinal differences are relatively great. There are rugged hills and mountains and valleys, narrow in the hills but widening as they de- 
bouch on the eastern plain. Between them are ridges, often very long and very narrow.

The highest summit in the vicinity of Quorn is Mount Brown (3,500 feet), although Devil's Peak is about as high. There are low mountains just north of the village, and about 8 miles north Mount Arden rises fairly precipitously. Not far from this mountain are interesting gorges in the main mountain mass on the west. At one of these is Depot Flat, where there is an interesting glacial till of preCambrian age, and another is Warren's Gorge, both of which were kindly shown me by Mr. Jensen, engineer, of Quorn. The valleys amid these hills and mountains are largely under cultivation, but the higher land is used for grazing purposes only. From this sketch of the general features of the topography at Quorn it can be rightly concluded that the village is very picturesquely situated.

The observations on the flora of the vicinity of Quorn were made from the various roads which radiate out from the village, so that it will be convenient to characterize the places visited by reference to the roads. So far as possible, I have retained the names of the roads in common use, but in one or two instances, when I did not know the name commonly used, I have given names suitable to my purpose. The roads are as follows: To the north of Quorn is what will be termed the Mount Arden road, which goes through the Flinders at this point to the Lake Torrens Plain, some miles beyond Mount Arden itself. The Port Augusta road parallels the railway and goes up to and through the Pichi Richi Pass. The Mount Brown road goes in a southwesterly direction to Mount Brown, passing Devil's Peak to the south. The latter lies between the two roads last mentioned. To the east of the town the Hawker road parallels the railway to and across the Willochra Plain, and lying south of this main road are two others, one here called the Stephenston road, the other the Melrose road. Both of these go to and onto the Willochra Plain, the former running east and west along the south side of Quorn Creek and its terraces, and the latter going at once over low hills to the plain. Thus there are about six main roads leading away from Quorn, of which three go to the Great Valley Plain to the east, and three into and between the mountains on the north and west of the town.

Although the rocks about Quorn are Cambrian, as the rest of the Flinders Ranges mainly are, they are of various composition and the soil derived from them is correspondingly varied. There are quartzite ridges and slate hills, the latter being of a rounded contour. The soil of the valleys around Quorn seems to be largely clay with a greater or less admixture of sand. The low, rounded hills along the Melrose road are underlain by a white material having the appearance of travertine limestone, which it may be. Much of the soil of the Willochra Plain is fine clay. 


\section{Climate.}

The mean annual rainfall for Quorn is 13.82 inches. The highest precipitation recorded was 25.77 and the least 7.43 inches. The mean, maximum, and minimum amounts of rain for each month are given in table 2 .

It will be seen from table 2 that Quorn is in the belt of winter rains. Beginning to fall in appreciable amount in the last month of autumn, the rains are maintained through the winter and until well into the spring, only about 30 per cent falling during the warm season. The mean rainfall of the latter is 4.18 inches. This is very little more than that for the same month at Copley, which is 3.82 inches, or 45.4 per cent of the whole. Therefore, the rainfall of the warm season at Quorn is relatively and actually small in amount, and possibly this gives the xerophytic stamp to the flora of the region, whereas the relatively, as well as actually, large winter rainfall makes possible an abundant vegetation. Further, it is this which makes wheatgrowing without irrigation possible in the region.

Although the rainfall at Quorn is fairly large, it has certain characteristics which show that the region is in fact semi-arid. The ratio of driest to wettest years is 1 to 3.4. In a humid region, as for example at Hobart, Tasmania, this ratio is much less, being 1 to 1.8. At Quorn the year having the greatest precipitation (1889) followed that with the least precipitation. However, there may be a series of dry or wet years when successive years would show a great consistency.

The rainfall on the Willochra plain, as would be expected, is less than at Quorn. For example, at Bruce, about 12 miles southeast of Quorn and on the western side of the plain, the annual precipitation is 9.88 inches. In closer relationship to the high mountains, as at Mount Brown, Melrose, and Wilmington, the precipitation is greater than at Quorn. The mean for the three places is $17.23,23.1$, and 18.23 inches, respectively. The rainfall on the upper slopes of Mount Brown and Mount Remarkable must be considerably more than that recorded for stations at their base.

I have not seen data on the temperature at Quorn, nor for any station near, but the temperature at Yongala, distant about 65 miles, may be useful as illustrating certain main features of the temperature conditions of the general region. The rainfall at Yongala is almost the same in amount as at Quorn, and the place has a considerable elevation. In a sense, therefore, the two are comparable. The following is a summary of the conditions at Yongala: Mean maximum, $69.2^{\circ}$; mean minimum, $46^{\circ}$; mean temperature, $59.6^{\circ}$; highest maximum, $107.6^{\circ}$; lowest minimum, $19.8^{\circ} \mathrm{F}$. The mean diurnal range is $24.9^{\circ}$ and the greatest daily range recorded at the station is $50.7^{\circ} \mathrm{F}$.

When the preceding temperature data are compared with those for Farina, as representing Copley, for example, it is seen that the 
latter station is hotter in summer and colder in winter and that the mean annual temperature is nearly $6^{\circ} \mathrm{F}$. higher than at Yongala. Moreover, the mean diurnal range is nearly $4^{\circ} \mathrm{F}$. higher at Farina, although the maximum diurnal range at that place is but little above that given for the more southern station. A somewhat similar relation, possibly less marked, may perhaps exist between Farina and Quorn. Thus, it will be seen, Quorn has cool winters and hot summers, with occasionally very high temperatures.

A characteristic of the temperature of the region which should be emphasized is its great daily variation. This feature, which is well marked in dry regions, is of undoubted importance in its effect on plants. An instance can be given which can not, unfortunately, be supported by complete data. In mid-October 1918, the day temperatures at Quorn were most agreeably cool, although it was the middle of spring. Green growth and fresh flowers were everywhere and there was little to suggest the brown hills of the summer to come. Particularly the roadsides in places were masses of blue from the flowers of the introduced Echium platagineum. One day late in the month the wind turned to the north and brought with it the high temperatures and the dry air of the Lake Torrens Basin. Rising to $96^{\circ} \mathrm{F}$. in a few hours, and with as sudden a drop in the relative humidity, the arid conditions swept over the country like a flame, drying and turning brown in a comparatively brief time most of the annual vegetation and severely testing the resistance of the perennials.

\section{Vegetation and Habitat.}

The flora of the Quorn region is rich in species and in individuals. The mountains are clothed with a wealth of shrubs and small trees, only the big outcropping rocks, often picturesquely serrated against the sky, being destitute of vegetation, and the hillsides and floors of the valleys are thickly covered with trees, shrubs, and lesser plants. Thus the vegetal aspect of the region is quite different from what was seen at Copley or in southwestern South Australia, with about 5 inches less rainfall, and, as would be expected, markedly different from that at Oodnadatta. It in fact compares well with the vegetation farther south, where the rainfall is much greater. Quorn has been settled many years. In earlier times the woody plants must have been much more numerous than at present and more generally distributed; but otherwise the vegetation is probably not greatly changed by the advent of the white man and his varied activities, and as a whole it probably well represents plant adjustments under relatively arid conditions.

The leading habitats in the vicinity of Quorn include the higher mountains, as Devil's Peak and Mount Arden; the lower ridges, some of which reach out to the Willochra Plain, the valleys between these ridges, the Willochra Plain, and finally Quorn Creek and its 
tributaries. No attempt will be made to describe the plants of these habitats, all of which, except the high mountains, were visited; but, as previously indicated, only such vegetational features as seemed most interesting will be taken into account, with general reference to the plants as a whole; and the situation of the habitats treated will be located by means of reference to roads going out from the village.

\section{Vegetation of the Valleys and of Willochra Plain.}

So far as can be judged from a very superficial view of the Willochra Plain in the vicinity of Quorn, and apart from the streamways passing through it, saltbushes of whatever sort constitute a prominent part of its natural vegetation. There is, however, much grass in places, particularly where the plain extends toward Quorn between the tongues of the low ridges, and as one goes up the valleys from the open plain and they become higher and narrower, the woody flora becomes of increasing importance.

The leading habitats as given in a preceding paragraph are in the main fairly distinct, but not always so. Where, for example, the plain narrows into the pass on the Port Augusta road, they rise to meet the hills and the three are merged, and in other places the hills may melt insensibly into the valley. Such a place occurs along the Mount Arden road at about 2 or 3 miles north of Quorn. Here the valley is somewhat rolling and there are remains of the original vegetal covering. By the roadside one sees several woody perennials, shrubs largely, of which Templetonia egena is the most numerous. This species occurs generally along the valley floor near Quorn and is very abundant in unused fields. It has a strict habit of growth and is leafless.

This shrub occurs in fairly loose groups which result from vegetative propagation in the following manner: A portion of the root-system is superficial and from some of the largest of such roots, and at a distance of 50 to $100 \mathrm{~cm}$. from the parent plant they may give rise to shoots. These eventually become independent plants.

Acacia calamifolia is another roadside shrub. This species has narrow filiform phyllodia, which are fairly numerous and about $7 \mathrm{~cm}$. in length. It occurs in fairly close aggregations, making a small but dense and low scrub mass. An examination of the root-system showed that there are no prominent superficial laterals, as in the last-named species, but that, on the other hand, the main tap-root is prominently developed. The species occurs in unused fields, as well as by the roadsides. Among other species growing near are the following:

Acacia hakeoides. sentis. sublanata.

Bursaria spinosa.
Cassia eremophila.

Cassia sturtii.

Eutaxia empetrifolia.

Glycine clandestina.
Helichrysum spiculatum.

Senecio anethifolius.

Templetonia aculeata. 
Acacia hakeoides is marked by its upright phyllodia, 5 to $10 \mathrm{~cm}$. in length and about $4 \mathrm{~mm}$. wide. A. sentis is a small tree with phyllodia about $20 \mathrm{~mm}$. in length. It has spinescent stipules. $A$. sublanata (plate $27 \mathrm{~A}$ ) is also a small shrub, fairly numerous, characterized by having phyllodia triangular in form and about $2 \mathrm{~mm}$., in diameter. Bursaria spinosa is a small shrub, 1.5 to 2 meters in height and with leaves occurring in groups. The leaves are fairly numerous and are 2 to $4 \mathrm{~cm}$. in length. The Quorn species appears not to be armed. Cassia eremophila, a shrub, is characterized by linear leaflets which arise from a phyllode-like leaf-stalk. In $C$. sturtii the leaflets are numerous, 6 to 10, and are about $10 \mathrm{~mm}$. in length. The leaves of this species can also be said to be abundant. Eutaxia empetrifolia (plate 27в) is a low shrub with linear leaves, about $3 \mathrm{~mm}$. long, but numerous. Glycine clandestina, a twining herb with slender leaflets, was one of the very few climbers which were seen at Quorn. Helichrysum spiculatum is a leafy herb clothed with cottony pubescence and is fairly abundant. Senecio anethifolius is a small shrub with numerous linear lanceolate leaves, and is also rather abundant. Templetonia aculeata is a low, rigid shrub with simple leaves, about $10 \mathrm{~mm}$. in length. It has prickly stipules and thus is one of the few armed species in the vicinity of Quorn.

All of the species whose salient characters have just been sketched were growing in vacant fields and by the roadside about 4 miles north of Quorn along the Mount Arden road. The valley at this place is fairly level, but as one goes farther north it ascends somewhat, becomes narrower, and by the time Mount Arden is reached, about 4 miles farther, trees characteristic of the higher hills are encountered. Here, and especially at Warren's Gorge (plate 26B), one finds small forests of the pine, Callitris robusta, at a place where a small stream breaks through, making the only means of access to the rounded slate hills beyond. The main ridge of the mountain through which the gorge runs rises steeply at one side and the shale hills ascend gradually on the other. The latter is the habitat of Callitris robusta, but it also occurs on the mountain itself. On certain of the slopes, however, mallee (Eucalyptus odorata and E. oleosa) occur on the upper reaches, while the middle of the slope is occupied by Zygophyllum sp., below which is Callitris, reaching down to Eucalyptus leucoxylon var. pauperita by the stream. There are no shrubs and very little grass or other annuals in the Callitris community, which extends close to the stream. Somewhat upstream from Warren's Gorge, and growing on tumbled rocks low on the hillside above it, is Sarcostemma australe. This is a leafless species of Asclepiadeæ which here hangs and sprawls over the rocks with a most weird effect.

At certain places along the Mount Arden road, which passes up a narrowing and ascending valley with characteristic changes in the vegetation as above suggested, one finds patches of the introduced 
and escaped annual Echium plantagineum; but it is most abundant nearer Quorn, especially along the Port Augusta road. It constitutes the dominant species of fairly large and isolated areas. Various grasses, however, make up the largest number of the herbaceous flora by which the valley floor near the village is thickly covered. How many of these are native and how many are introduced, however, was not determined by me; but it seems possible that at least on the lowest portions of the valleys there must always have been a grassy vegetation, so that the grassland-forest formation of the regions of a relatively large rainfall, as in portions of the Mount Lofty Ranges near Adelaide, can be said to be represented at this place.

One of the most striking communities on the Mount Arden road is that of the mallee, an example of which lies about 2 miles north of Quorn. The dominant species of the mallee scrub are Eucalyptus odorata and $E$. oleosa. These are small trees with a shrubby growthhabit and the canopy top characteristic of the mallee (plate 26c). The scrub is fairly dense and the number of species comparatively large. The following list, which is doubtless far from complete, comprises those most conspicuous:

Acacia iteaphylla. oswaldii. pycnantha.

Cassia sturtii.

Cassinia aculeata.

Dodonæa attenuata.

Eremophila brownii. oppositifolia.

\section{Eucalyptus odorata.} oleosa.

Eutaxia empetrifolia.

Exocarpus aphylla. spartea.

Hakea leucoptera.

Indigofera australis var. minor.

Jasminum lineare.
Loranthus pendulus.

Myoporum platycarpum.

Olearia pannosa. pimeleoides.

Pittosporum phillyræoides.

Rhagodia parabolica.

Triodia irritans.

Zygophyllum billardieri.

When examined somewhat in detail, the scrub reveals conditions rather different from those before seen, as, for example, at Copley. The larger number of individuals indicates better water relations than at stations farther north or along the East-West Railway. In addition, a study of the leaf-surface would probably show that the transpiring area is considerably larger as well. In certain other regards, however, a similarity exists. For instance, there is little shade in the scrub in any of the dry localities seen, including Quorn. The mallee scrub at Quorn is here compared with the mallee scrub in the Mount Deception Range west of Copley. Should comparison be made with the hillslope community as a whole at Copley, all of these conditions and differences would be greatly increased.

Each of the three species of Acacia observed in the mallee scrub has prominent phyllodia, but those of $A$. pycnantha, the "golden wattle," are actually large, measuring about $13 \mathrm{~cm}$. in length by about $2 \mathrm{~cm}$. in width (plate $27 \mathrm{c}$ ), and they are numerous on the small tree also. This species is not present in large numbers in the scrub, although, as will appear below, it forms a small grove on the river bottoms near the village. It occurs in the more moist portion of the state, 
as in the Mount Lofty Ranges near Adelaide, so that its presence at Quorn suggests that that place may be regarded as being on the transition line between the dry north and the humid south. This view is substantiated by rainfall statistics also, as well as by other facts touching plant distribution.

Cassia sturtii is present in small numbers. The leaflets are 6 to 10 in number, and both the narrower and the broader leaved forms are to be found in the scrub. At Quorn it forms a shrub about 1 to 1.5 meters high and ranks with the golden wattle in the brilliance of its flower. The species has the appearance of having a greater leaf surface than at Copley.

As above given, Eucalyptus odorata, the mallee, is a small tree, about 8 to 10 meters high at Quorn, and has the so-called "mallee" habit of growth-that is to say, in place of there being one main shoot only, many shoots of equal rank and of approximately equal length spring from a thickened base. Each shoot ends in a number of small branches of unequal length which bear only leaves. The general canopy effect is indicated in plate 26c. The leaves of $E$. odorata, as well as of $E$. oleosa, are relatively small. They are 8 to $12 \mathrm{~cm}$. long and usually less than a centimeter wide.

Of the two species of Eremophila, E. brownii is the most widely distributed in South Australia. It was seen at Oodnadatta and at Copley and occurs in the southern and western portions of the state as well. The leaves are linear and 2 to $3 \mathrm{~cm}$. in length.

Exocarpus spartea and $E$. aphylla are not common in the mallee scrub, although the latter is fairly abundant. The latter is a shrub 2 to 4 meters high and with its leafless branches is very striking. $E$. spartea has linear-subulate leaves, which, however, do not conceal the broomlike branches. The leaves of this species appear to fall away easily, so that upon the advent of dry seasons the shoots are probably bare. Eutaxia empetrifolia is a small, weak shrub with minute linear leaves.

Another species common in the scrub is Dodoncea attenuata; this has a dense shoot whose leaves and fruit are covered with a resinous substance. Hakea leucoptera, which was found at Copley also, is rather abundant on the outskirts of the scrub and in the adjacent open fields. Hakea is a shrub, 1.5 to 2.5 meters high, which occurs in open colonies. A portion of the root-system of the species lies close to the surface of the ground and from such roots daughter shoots spring up, reproducing the plant vegetatively (plate 28B). From the frequent occurrence of Hakea in groups, as noted, it seems that this is a common way of its propagation.

Of the other species, Pittosporum phillyrcoides is one of the most interesting. This is a small tree with drooping branches and leaves about $15 \mathrm{~cm}$. long by 5 to $8 \mathrm{~mm}$. wide. In the mallee scrub there is also a fairly thick growth of Triodia irritans. Loranthus pendulus occurs fairly abundantly on Eucalyptus oleosa in the scrub. However, 
the Loranthaceæ are not nearly so common here or elsewhere about Quorn as at Copley.

Near the Port Augusta road and about 2 miles west of Quorn are other mallee scrubs in which there appear to be fewer species than in the scrub just described. Low ridges, extending from the higher hills and mountains to the Willochra Plain (plate 28A), are covered with Eucalyptus oleosa and E. odorata as the dominant species. Here were also found Dodoncea bursarifolia and Pholidia santalina (syn. Eremophila) (plate 23A).

Where the valley ascends to Pichi Richi Pass, on either side of the road are hills a portion of which, as just described, bear mallee scrub; but some of the hills bear scattered low shrubs and are heavily covered with grass. Of the shrubs, Acacia continua (plate 23c) is possibly the most common, although it occurs but sparingly. Widely scattered specimens of Casuarina sp. also occur, but the grasses Triodia irritans, the porcupine grass or Spinifex, and Trichinium spathulatum are the dominant species.

Somewhat higher in the valley the mallee and other species of Eucalyptus come to the valley floor and here the grass is absent. It seems possible, although this will require verification, that the mallee-covered ridges above referred to are shale, while the grassy hills are quartzite. In the vicinity of Quorn, so far as my observation went, it appeared that bunch-grass and Casuarina were both found where there was an outcropping of the latter. As an example of this, the vegetation of the quartzite ridge east of the Mount Arden road and about 3 miles north of Quorn may be given.

\section{Vegetation of Low Hills.}

Mention has already been made that the low ridges which extend in a generally easterly direction to the Willochra Plain from the higher hills and mountains are in part at least covered with mallee and that certain of the hills near the Pichi Richi Pass, on the Port Augusta road, are grass hills on which there are scattering woody perennials. The vegetation of three other hills or ridges should be mentioned. Of these, the ridge last referred to as being along the eastern side of Mount Arden road has vegetational features of interest. On the western slope is a heavy covering of bunch-grass growing very thickly, Triodia irritans and Trichinium spathulatum, with a few and scattering specimens of "mallee" and Xanthorrhoe semiplana (plate 28c). Near the summit of the ridge the grass becomes more scattering and Xanthorrhoea semiplana occurs in considerable numbers. On the top, mallee dominates the woody perennials, although Callistemon teretifolius also occurs (plate 23в). Somewhat lower on the ridge and on the southern slope mallee ceases and Casuarina stricta is met. Whether, as may be possible, the distribution of the mallee is coincident with the change from quartzite to shale was not determined. 
The Melrose road passes over hills on its way to the western edge of the Willochra Plain. These hills, at least in part, appear to be delta fans from the main uplift farther to the west, and in part to be eastern ends of low ridges which reach to the western higher hills. Within reach of the road a considerable variety of vegetation is to be found, of which may be mentioned the Casuarina scrub about 4 miles east and south of Quorn. The vicinity of the scrub is largely used at present in agricultural operations, but there have been left, apparently little touched, several acres of "oak" land and a small contiguous area containing other native vegetation. The Casuarina scrub is an open growth with Casuarina stricta predominating. The species here forms a small tree 3 to 5 meters high. It reproduces vegetatively from shoots which arise from superficial roots. Another species common in the Casuarina scrub, and which reproduces in a similar manner, is Templetonia egena.

In addition to the above the following occur in the same community: Acacia calamifolia (plate 23D), A. oswaldii, Exocarpus aphylla, Hakea leucoptera, Heterodendrum olecfolium, Lycium australe, Nitraria schoberi, and Triodia irritans. Besides these species there is "sandal-wood," probably Pittosporum phillyrooides, which occurs sparingly.

Inasmuch as some of the more obvious and interesting features of all of these species have been commented on in the preceding pages, further description is not necessary. It will be noted, however, that three of the species, including Hakea leucoptera, reproduce vegetatively from the roots (plate $30 \mathrm{c}$ ). The grass, Triodia, is poorly represented and the floor of the scrub is fairly clean. The species above listed are not equally distributed throughout the scrub, but a portion occur on the edge of the Casuarina community more plentifully than in the center, as, for example, Acacia oswaldii, Hakea leucoptera, Heterodendrum olecefolium, and Nitraria schoberi. Here, however, as in certain other places in the vicinity of Quorn, the possibility enters that the primitive conditions may have changed through the agency of man. It is impossible at this time to say whether, for example, the Casuarina might have been removed from the latter scrub or whether it never occurred there.

In the sketch of the physiography of the Quorn vicinity mention was made that the Willochra Plain is continued as narrowing valleys toward the higher mountains. Between these valleys, and near where they debouch onto the plain, are low hills, the terminations of those which reach out from the high land west of the village. For most of their course the hills are covered with a scrub of some sort, as has been described, but at their plain-ends the condition is quite different. Here there is a scattering population of "blue bush," mainly Kochia sedifolia. At the base of the ridges other halophytes occur and espe- 
cially by the unimportant washes are scattering specimens of Acacia sentis. Strictly speaking, the latter species belongs rather to the valley than to the hill flora.

\section{Vegetation of the Washes.}

It has been remarked that at Quorn there is frequently no sharp distinction between valley, hill, and stream-plain, but that in places the flora of the three may merge, even if in others they are quite separate. This is possibly less true of the vegetation of the streamways than of the other formations. The characteristic species of the streams is Eucalyptus leucoxylon var. pauperita. This is strictly limited to streams. It is a good-sized tree, becoming about 7.6 meters in circumference (plate 30B). By the low banks along the washes, which are dry most of the year, are other species which also rarely, or never, occur elsewhere. For example, Acacia pycnantha forms a small thicket by the wash near the Mount Brown road about 3 miles southwest of Quorn (plate $30 \mathrm{~A})$, but there are no other species of woody plants here.

\section{Root Characters.}

Some observations were made on the root-habits of the mallees, Eucalyptus oleosa and $E$. odorata, and of the large gum, $E$. leucoxylon var. pauperita, of the washes. The former was especially studied in the small mallee community about 3 miles north of Quorn. Here a narrow wash runs by the edge of the scrub, where the soil is fairly coarse and where rock underlies it to a depth of about a meter; it was found that the tap-root was poorly developed, but that there were numerous radiating superficial roots. In a typical specimen there are about 12 main laterals of this character which are placed 23 to $45 \mathrm{~cm}$. beneath the surface (plate $31 \mathrm{~A}$ ). Many roots, about $2 \mathrm{~mm}$. in diameter, arise near the bases of the large laterals and go directly down.

At another place, by the Port Augusta road and about 4 miles west of Quorn, a fairly deep wash also exposes roots of mallees growing along its side. Here the wash is about 2 meters deep and, although there does not appear to be rock to limit possible root penetration, all of the species had the superficial type of roots well developed. In one instance a root was traced 11 meters from the base of the tree, and at a distance of 7 meters it had a diameter of $2.5 \mathrm{~cm}$. In another case, after having extended 2 meters from the tree close to the surface of the ground, the horizontal root sent a branch straight down. This was about three times the diameter of the parent root and was traced to a depth of 2 meters. The horizontal roots were found to lie usually within $20 \mathrm{~cm}$. of the surface of the ground.

Owing to its usual position in the bottom of the washes, the roots of the gums here are rarely much exposed, but it is usual for several prominent roots to take their origin close to the surface of the ground; in one instance it was found that such roots may extend for a long distance near the surface. By the streamway, for example, about a 
mile beyond Warren's Gorge, where there are many large specimens of gum, probably Eucalyptus leucoxylon var. pauperita, there is at one place a group of superficial roots which are exposed for a distance of about 16 meters and probably extend much farther (plate 31в). These were situated about $20 \mathrm{~cm}$. beneath the surface of the ground.

\section{MALLEE AND THE MALLEE REGIONS.}

The mallee scrub is one of the largest and most distinctive plant formations of South Australia. The term includes species of Eucalyptus of especial habit of growth which may or may not be obligate. In the mallee the stem is shortened into a large bulbous base, into which the enlarged root-crown insensibly merges, and from this woody mass there spring branches, usually of about equal length, which bear leaves at their tips. Typical mallees thus have a rounded shoot, canopy-like, and the general effect is that of large shrubs. Among the mallees with consistent habit are: Eucalyptus bicolor, E. calycogona, E. dumosa, E. goniocalyx, E. incrassata, and $E$. oleosa.

Eucalyptus odorata is one of the species with tree habit which can assume the mallee form under appropriate conditions. The enlarged base of the mallee often is of very large size. Thus Maiden (1904:93) states that it becomes as much as 9 feet in diameter where the conditions are favorable for its development. The base is flattened and is firmly planted and held in the soil by the numerous roots, most of which are superficial and extend outward for several meters. The bulbous base is often so large that it will hold the shoot upright even when all of the roots are removed. It constitutes a notable organ for the storage of water. Maiden says that the base may be so full of moisture that it would be an almost endless task to attempt burning it out. When finally dry, however, the mallee "root" becomes of value as a fuel and is largely used for this purpose.

The mallees occur in regions with winter rains, although the total amount of precipitation may vary considerably (Osborn, 1914). Thus, in regions of the mallee the rainfall may range from about 9 to 19 inches. It was seen in the mountains west of Copley, in the sandhill region at Ooldea, near Saltia, and at Quorn. At Ooldea the mallee is growing under a 9-inch rainfall, but at the other places it is more than this, and a relatively large rainfall (or at least relatively good water relations) is apparently a prerequisite to the attainment of the largest growth of the mallee.

In the northern or central portions of the state there are large communities of mallee, but its largest development is attained in the southern part, especially on the bottoms of the Murray River and in the region to the west of Spencer Gulf. It was seen by me west of the Murray River, between Blanchtown and the highlands which border the Murray Basin on the west. 


\section{Physical and Chimatic Features.}

The region west of Blanchtown, which lies on the western bank of the Murray River, is nearly level. However, it has the appearance, although whether this is true in fact was not learned, of rising as one approaches the river.

In this characterization of the region Howchin (1909:95) says:

"The greatest development of the coastal plains in South Australia is in the southeast, between the central highlands and the Victorian border. It is often spoken of in three sections: The Murray Flats, between the ranges and the River Murray; the Ninety-Mile Desert, between the river and the Victorian border, by the old stock routes; and the South-East or most southerly section. The physical features throughout are very uniform. Gently undulating ground, with a few more prominent ridges; light, sandy soil which frequently changes to a travertine-limestone crust."

The Murray Flats, which were visited, forms a part of the great Murray-Darling Basin, which is the most extensive river basin on the continent. This basin probably should be considered as constituting an important highway for the migration of plants. Stretching over about $12^{\circ}$ latitude, and thus including within its extent a great variety of climate, it nevertheless is fairly consistent in having relatively good water relations throughout.

\section{Rainfall and Temperature.}

Blanchtown is in the belt of winter storms. The average annual precipitation is 10.77 inches. But at Blanchtown, as at other semiarid stations, there is not a little variation from one year to another in the amount of the rainfall. The least recorded up to 1912 was 5.84 inches and the greatest was 19.71 inches. Thus, although at times the rainfall may be considerable, it is nevertheless always periodic, so that there is a marked season with no rains of moment, or none at all, during which the perennial plants may be subject to conditions of extreme drought.

There are apparently no temperature records available for Blanchtown. The nearest meteorological station is Kapunda, about 32 miles west. The altitude of the latter is 803 feet, and hence the temperature conditions can not be taken as being parallel to those at Blanchtown, although they are probably similar. However this may be, the temperature for Kapunda may serve to illustrate certain features of the climate of the mallee country to the west of the Murray, and for this reason they are summarized in table 15, supplied by the Commonwealth Bureau of Meteorology. It will be seen that the mean maximum temperature at Kapunda is $71.1^{\circ}$ and that the mean minimum is $50^{\circ} \mathrm{F}$. The highest temperature at the station recorded up to 1912 was $113^{\circ}$ and the lowest was $27^{\circ} \mathrm{F}$. 
TABle 15.-Temperature at Kapunda, South Australia, in degrees Fahrenheit.

\begin{tabular}{|c|c|c|c|c|c|c|c|c|c|c|c|c|}
\hline & Jan. & Feb. & Mar. & Apr. & May. & June. & July. & Aug. & Sept. & Oct. & Nov. & Dec. \\
\hline Mean maximum. & 85.9 & 85.7 & 79.2 & 70.5 & 63.3 & 57.2 & 55.7 & 59.0 & 64.0 & 71.0 & 78.8 & 83.4 \\
\hline Mean minimum... & 58.5 & 58.8 & 54.9 & 50.3 & 46.1 & 43.3 & 41.4 & 42.9 & 44.8 & 48.4 & 52.9 & 56.6 \\
\hline Mean temperature. & 72.2 & 72.3 & 67.0 & 60.4 & 54.7 & 50.2 & 48.6 & 50.9 & 54.4 & 59.6 & 65.5 & 70.0 \\
\hline Maximum *...... & 113 & 109 & 104 & 95 & 93 & 73 & 73 & 81 & 89 & 97 & 108 & 110 \\
\hline Minimum *........... & 41 & 41 & 40 & 35 & 30 & 27 & 29 & 30 & 29 & 33 & 38 & 39 \\
\hline Mean No. of days $90^{\circ}$ or over & 12 & 10.1 & 5.0 & 0.4 & 0 & 0 & 0 & 0 & 0 & 1.3 & 4.9 & 8.9 \\
\hline Mean No. days $100^{\circ}$ or over. & 4.4 & 3.2 & 0.4 & 0 & 0 & 0 & 0 & 0 & 0 & 0 & 0.6 & 2.7 \\
\hline Mean No. nights $40^{\circ}$ or under & 0 & 0 & 0 & 0.6 & 5.4 & 8.8 & 12.9 & 9.7 & 6.8 & 2.9 & 0.4 & 0 \\
\hline
\end{tabular}

* Fractions of a degree are disregarded in maximum and minimum temperatures.

Vegetation.

When viewed from the Central Highlands west of the Murray Flats the landscape has much of the monotony as well as color of the sea. The vegetation is bluish green and extends mile on mile without marked irregular features, except an occasional rectangular homestead, to create diversion either of color or form. Not far below the eastern horizon a faint, lighter line, the precipitous farther bank of the Murray, cuts the view and reveals where the river, submerged beneath the general level of the plain, makes its tortuous course to the sea. Once entered, the woody vegetation of the Murray Flats retains its apparent monotony. On every side the mallees of the scrub lift their rounded shoots to a height of about 3 to 6 meters (plate 32c). Furthermore, there is little apparent difference between unlike species, and there are few woody plants of genera other than Eucalyptus. So far as could be determined from a superficial examination, $E$. oleosa was the dominant species, although $E$. odorata was found in large numbers also. The latter species occurs both as a mallee and (at the western edge of the mallee scrub proper) as a small tree. Growing in the scrub were numbers of Dodoncea bursarifolia and separated groups of Melaleuca parviflora (plate $32 \mathrm{~A}$ ). The individuals of the mallee scrub are frequently so closely placed that the shoots are in contact. The mallees cease to be dominant forms as the river gorge is approached, and other trees, prominent among which are species of Casuarina, are fairly abundant. Individual specimens of mallees, however, may be found to the edge of the gorge.

The Murray River and its flood-plain are sunk approximately 30 meters below the general level of the Murray Flats. When seen (November 11,1918 ) the river was still running high and was about 200 meters from bank to bank. A narrow flood-plain lay on one or both sides of the stream, and on these there are open forests of large gums, Eucalyptus rostrata, and a few specimens of introduced Salix sp. (plate 32B). The bases of many of the trees were covered with water and had been so covered for several months. No mallees were seen on the flood-plain. 
At various places on the Murray Flats west of Blanchtown, farming operations have been carried on for several years. It is not uncommon to see the farm fences composed of the "roots" or "stumps" of the mallees. These are piled loosely into long and low walls. I was interested to note that there were no especially large roots in the fences. This agreed with what I had seen in excavations by the roadside in which mallee roots had been in part exposed. From other observations also it appeared that the stem bases of the mallees of the region were usually not large. So far as the roots of the mallee of the region are concerned, it seems probable that they are largely, but not exclusively, superficially placed. They are not infrequently exposed in part by the removal of the soil by erosion, and under such circumstances the stem base appears as a flattened crown lying close to the level of the ground, from which the superficial absorbing roots radiate like spokes in a wheel.

\section{MORPHOLOGICAL ASPECTS OF THE XEROPHYTIC FLORA OF SOUTH AUSTRALIA.}

\section{LEAF-SIZE AND LEAF-FORM.}

One of the striking features of the vegetation of South Australia is the xerophytic stamp that characterizes every shrub and tree. This impression is given on every side- on the plains about Adelaide, in the Mount Lofty Ranges, on the Murray River flats, on the rolling Central Highlands, about Quorn and Mount Remarkable, as well as in the far north and in the southwestern districts. Very naturally the xerophytic characters increase with an increase in the dryness of the habitat. Where the rainfall is most favorable the plants on the whole are relatively large as well as abundant and the leaves they bear are not only numerous but relatively large. Thus the differences noted are those of degree and not of quality.

The range in the modifications, however, may be extreme, amounting, in effect, upon the contrast of the extremes, to qualitative differences. Thus aphylly is occasionally met with in genera with leaf-bearing or phyllodia-bearing species. A condition of aphylly connotes the absence of leaves at all times and at all stages of development, save possibly in seedlings. There are apparently no perennials with deciduous habit through which the condition of aphylly becomes a recurring one. On the contrary, the foliar organs, of whatever nature, can be said to be constant, used in a restricted sense, and thus are exposed fully to the greatest range of intensity of the environmental conditions where the species occurs. The adjustments to the environment take place along different lines and naturally affect the shoots 
in a great variety of ways, such as the cuticularization of exposed surfaces, the formation of trichomes, the marked formation of sclerenchyma, the development of resinous or other secretions which cover the shoots at least in part, the formation of water-storage organs or cells, a modification in the direction of growth in some manner related to light and, not to extend the list, the size and the form of the chlorophyllous organs themselves. The precise steps, however, by which such modifications may have taken place, even if they are apparently related directly to differences in the water relations, for example, are necessarily obscure and are subjects for physiological research.

A survey of the leaf characters of representative perennials of South Australia shows a strong tendency to develop leaves, or phyllodia, which are relatively long. This is most marked in the very dry regions. In this type of leaf modification there is a reduction in the amount of chlorenchyma of whatever kind, and the leaves may be reduced to little more than midribs with narrow wings. In the case of phyllodia, however, the leaf-stalks on which they are based may become very long, which apparently is also a secondary development. Under more moist conditions of growth, however, the latter undergo a tertiary modification by becoming relatively wide, thus increasing the surface to a marked extent. Such reversion, in effect if not in fact, occurs only under relatively good water relations. The phyllodia of Acacia pycnantha, the "golden wattle," illustrate the feature last referred to. The transpiring surface is also increased by the increase in length alone, so that there is in this particular an apparent conflict in the direction of development, as well as a real exception to the general tendency of species to undergo a reduction of the leaf-surface with a decrease in the amount of available water.

These features can be illustrated by a few examples of leaf or phyllodia sizes. Heterodendrum olecefolium is a small tree and occurs in aridsemiarid regions. The leaves are about $110 \mathrm{~mm}$. in length by about $14 \mathrm{~mm}$. in width, and have an area, one side, of approximately 1,080 sq. $\mathrm{mm}$. The ratio of length to width, therefore, is nearly 8 to 1 , while the ratio of area to length is approximately 19 to 1 . Acacia stenophylla was found in the desert-arid regions. The phyllodia of the species may become of great length, some $375 \mathrm{~mm}$. long; they measured $5 \mathrm{~mm}$. in width and had a surface, one side, containing about 1,700 sq. $\mathrm{mm}$. The ratio of length to width is in the latter instance about 75 to 1 , and that of area to length is about 4.5 to 1 . In this connection it can be remarked that in simple leaves, circular in shape and thus with the greatest possible area, the ratio of length to breadth is unity and that of area to length varies with the diameter and increases in geometrical ratio directly with the increase in diameter. In the case of leaf sizes about equal to the "microphylls" of Raunkiaer (Fuller, 1918), 2,025 sq. mm., the ratio of area to length (diameter), in circular leaves is about 40 to 1 . 
A "composite" leaf constructed upon the average length and width of the leaves of 30 representative species growing in the desert-semiarid regions of South Australia has a length of $64 \mathrm{~mm}$. and a breadth of $5 \mathrm{~mm}$., giving the length-breadth ratio nearly 13 to 1 . Measurements on the phyllodia of 16 species of Acacia give an average length of $84 \mathrm{~mm}$. and an average width of $3.5 \mathrm{~mm}$., or a ratio of length to width of 24 to 1 . The average leaf-area was not determined in either class. In another series of 29 species both leaves and phyllodia were measured and the area computed. In this case the ratio of area to length was 4.7 to 1 . For the leaf sizes observed, it would appear, therefore, that the ratio of area to length is greatly under that to be expected in species growing under moist conditions-that is, in species which bear leaves with equal transpiring surface, or, in other words, with better developed lamina. The length-width and the area-length ratios, for this reason, may possibly constitute an index of the degree of xerophylly of the species. Measurements of leaf and phyllodium sizes are given in table 16.

TABLE 16.-Leaf measurements, desert-arid perennials of South Australia.

\begin{tabular}{|c|c|c|c|c|c|c|c|}
\hline Species. & Length. & Width. & Area. & Species. & Length. & Width. & Area. \\
\hline 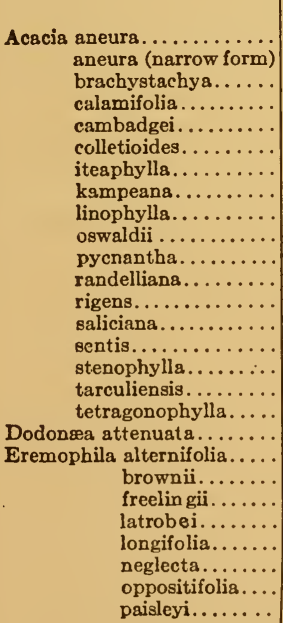 & $\begin{array}{r}m m . \\
57 \\
55 \\
100 \\
67 \\
20 \\
12 \\
88 \\
64 \\
140 \\
47 \\
110 \\
70 \\
85 \\
75 \\
31 \\
375 \\
34 \\
30 \\
85 \\
34 \\
26 \\
55 \\
32 \\
80 \\
46 \\
44 \\
28\end{array}$ & $\begin{array}{l}m m . \\
8 \\
2.5 \\
1.5 \\
1 \\
8 \\
1 \\
5 \\
7 \\
1.5 \\
4 \\
26.6 \\
2 \\
1.5 \\
5 \\
3.5 \\
5 \\
10 \\
1 \\
3 \\
2 \\
4 \\
7 \\
1.5 \\
5 \\
5 \\
1.7 \\
2\end{array}$ & $\begin{array}{r}\text { sq. } m m \text {. } \\
350 \\
100 \\
140 \\
65 \\
140 \\
12 \\
350 \\
410 \\
210 \\
175 \\
1,050 \\
130 \\
120 \\
350 \\
100 \\
1,700 \\
300 \\
30 \\
200 \\
30 \\
110 \\
230 \\
32 \\
230 \\
190 \\
66 \\
50\end{array}$ & 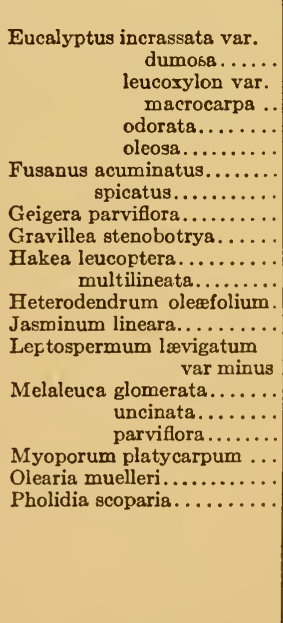 & $\begin{array}{r}m m . \\
87 \\
90 \\
75 \\
86 \\
72 \\
47 \\
47 \\
135 \\
72 \\
210 \\
110 \\
96 \\
\\
26 \\
20 \\
25 \\
9 \\
67 \\
90 \\
20\end{array}$ & $\begin{array}{c}m m . \\
18 \\
25 \\
10 \\
18 \\
7 \\
10 \\
3.5 \\
1.5 \\
2 \\
6 \\
14 \\
5 \\
5 \\
1 \\
1 \\
1 \\
7 \\
6 \\
1\end{array}$ & $\begin{array}{r}8 q . \mathrm{mm} . \\
1,280 \\
1,460 \\
650 \\
1,000 \\
300 \\
290 \\
160 \\
190 \\
140 \\
1,200 \\
1,080 \\
450\end{array}$ \\
\hline
\end{tabular}




\section{FEATURES OF ROOTS OF SOUTH AUSTRALIAN PLANTS.}

Whatever may be the reasons, there appears to be a comparatively limited range of variation in the types of roots developed in perennial plants of South Australia, and possibly of Australia taken as a whole; in herbaceous forms, however, such does not appear to be the case. Thus there are herbaceous species with perennating fleshy roots of various types, as well as those with roots that are fibrous, and the latter may be various as to form, direction, and extent of their development. As to the perennials of the state, an analogous condition seems not to exist. The roots of perennial plants may be divided, as to general development, into those which may be said to be specialized and those which are generalized. The former are either obligately deeply penetrating or they are obligately shallowly placed. In certain regions, as for example in southern Arizona, all three root-types are to be found. To mention only one root-type, the obligate shallow form, it may be said that this is associated in Arizona almost exclusively with the quality of fleshiness in the species. In South Australia, on the other hand, roots of this character appear to be quite wanting, or at least they remain to be demonstrated. Possibly this is because of the lack of fleshy perennials of a type analogous to the American cacti. It therefore appears to be necessary to account for the absence of perennials with water-storage capacity in South Australia in order to account for the failure to develop obligately shallow roots. Both of these are certainly not without their difficulties.

It would appear to be puzzling that herbaceous species with perennating subterranean parts are developed in large numbers in a region in which fleshy perennials do not occur. It does not seem improbable that certain of the environmental conditions favorable to the growth of the one may also be favorable to that of the other. Thus, the roots of certain cacti, as mentioned in another place, require a well-aerated soil as well as one that is suitably moist and of a fairly high temperature. In all cases moisture is a condition sine qua non of root-growth. The optimum temperature for growth may vary as between different fleshy perennials, but it remains to be shown that the same is true as to the oxygen-supply. That, as a matter of fact, such fleshy plants as various species of the cacti can live in parts of Australia, including South Australia, is well known. So far as is known, also, these introduced forms develop roots of a type characteristic of them in other lands. In short, it can be said that the type of roots which develop in the upper soil layers, and which do not normally attain to any considerable depth in the soil, is quite wanting in South Australia, for reasons which are not apparent.

It is probable that a close study of the roots of the perennials would show many with a well-developed tap-root and with an obligate, deeply penetrating habit of growth. As a matter of fact, I saw but 
few that appeared to be such and none that I was quite sure of. There are many species with what may be called an intermediate condition. Such would be Kochia sp., Pholidia scoparia, and Eremophila freelingii at Copley, and several species of Eucalyptus of different habit of growth and at different places. At Quorn, however, Acacia calamifolia seems to have a root-system in which the tap-root is very well developed and in which the laterals do not appear to exist near the surface of the ground. To surely determine the point would require more observations on the habits of the species than I was able to make.

Without doubt the most usual type of root-system in the perennials of South Australia is the generalized form, or that type in which the roots are plastic, so that under one set of conditions they may penetrate deeply, under another they may lie close to the surface of the ground, or finally under a third they may both penetrate deeply as well as extend widely in one and the same specimen. As will be gathered from what has been remarked in the preceding paragraphs on specialized roots, practically all of the perennials whose roots were observed have the generalized root-habit. For obvious reasons, however, only the more superficially placed of the roots of such plants can usually be studied, but in certain instances the development of such superficial roots is very marked. For example, at Warren's Gorge, near Quorn, the superficial roots of Eucalyptus leucoxylon var. pauperita, which lie about $20 \mathrm{~cm}$. deep, were traced 16 meters away from the base of the tree. Marked development of superficial roots was seen in other species of Eucalyptus, including mallees, in several localities; no very deeply placed roots of species of the genus were actually observed. By a wash near Quorn a penetration of 2 meters was noted and the root gave every appearance of sinking deeper than this. Reports, however, were not wanting to the effect that roots of Eucalyptus might attain to very considerable depths and in fact were not infrequently met in digging operations. I was unable to verify such reports, but from what I saw of the roots of Eucalyptus I would suppose deep root penetration to be possible under appropriate conditions.

An interesting feature of species having generalized roots is the frequency with which they reproduce vegetatively. This occurs through the springing of shoots from the horizontally placed roots. Although the vegetative reproduction was not studied especially, it was noted at Quorn in Casuarina sp., Hakea leucoptera, and Templetonia egena, and observed at other places and in other species.

Especial study of the roots of the perennials of the state will probably show many interesting forms of specialization and adjustments to the physical environment which may be of moment in the survival of the species. It does not seem improbable, for example, that roots 
of a semi-fleshy type may be found in species of Xanthorrhoea, as is the case in analogous forms elsewhere. The high water-retaining capacity of the roots of certain woody species, as Gravillea stenobotrya and other forms, is probably of great importance in the water-economy of such plants. But the most striking of these must be considered to be species of Eucalyptus which assume the mallee habit. In them the short stem and the enlarged root-crown together constitute a very remarkable water-storage organ which would seem to be capable of holding sufficient water to carry the shoot over long periods of drought. In such a bulbous organ it would be expected that the "feeding" roots would be so situated that the utmost advantage would be taken of the rainfall. This would mean the placing of the roots at such a depth as would insure the absorption of water very soon after the commencement of rains as well as the continuation of absorption of water for a relatively long period after the rains were over. It is possible that a further study of the roots of the mallees would show such rootdevelopment, and in the species having the mallee habit there is a tendency looking to specialization in relatively shallow roots, even if under favorable conditions a considerable root-depth may be attained. A study of species with a facultative mallee habit would be of interest in this connection.

The depth at which the superficial roots of perennials are placed is variable, but in no case observed was it seen to be as shallow as those of certain cacti in southern Arizona, for example. At Oodnadatta the horizontal roots of Eucalyptus rostrata lie at a depth of about $60 \mathrm{~cm}$. beneath the surface, but these may not be the most shallowly placed roots of the species. Acacia linophylla of the sandhills east of that place has superficial roots which run within a very few centimeters of the surface, although the exact depth was not determined. At Copley the most superficial laterals of specimens of Pholidia scoparia, growing by a wash, were seen to lie at a depth of $40 \mathrm{~cm}$., and the superficial roots of Kochia sp., in a similar situation, were ascertained to lie within about $10 \mathrm{~cm}$. of the surface. At Quorn the superficial roots of Eucalyptus leucoxylon var. pauperita were found to be $20 \mathrm{~cm}$. deep.

At Copley some measurements were made on the greatest penetration of the roots of annuals to be found at the time of my visit, July-August, showing that for the most part they lie within $10 \mathrm{~cm}$. of the surface of the ground. The extreme depth observed was in the case of a specimen of Zygophyllum crenatum growing on a slope below high and rocky hills, where the soil was relatively coarse. Here in one specimen a penetration of $13.5 \mathrm{~cm}$. was found, although in two others of the same species the extreme depth attained was 8 and 8.5 $\mathrm{cm}$., respectively. 
NOTES ON SOME STRUCTURAL FEATURES OF PERENNIALS.

Although the material at hand was not primarily collected or prepared for anatomical study, it was found that by proper handling and treatment it yielded much better results from this point of view than was at first expected, probably because so large a proportion of the tissues of the leaves or phyllodia is composed of mechanical tissue of whatever sort. The following sketch of some of the most striking features of the anatomy of the chlorophyll-bearing organs of representative perennials is based, so far as the original observations are concerned, wholly on the study of such herbarium material.

In this brief survey of the anatomy of the species the observations have been almost wholly confined to such tissues as are most directly concerned with the water relations of the plants. Scant reference has been accorded any other features. No attempts, therefore, have been made looking to thorough or exhaustive treatment, much as that is desirable, inasmuch as the subject of structure should and undoubtedly will receive adequate attention from others who will study living material, which was not practicable in the present instance. Observations were made on the following species:

$\begin{array}{ccl}\text { Acacia aneura. } & \text { Eremophila alternifolia. } & \text { Pholidia scoparia. } \\ \text { continua. } & \text { brownii. } & \text { Fusanus acuminatus. } \\ \text { linophylla. } & \text { latrobei. } & \text { Gravillea stenobotrya. } \\ \text { tarculiensis. } & \text { longifolia. } & \text { Hakea leucoptera. } \\ \text { tetragonophylla. } & \text { neglecta. } & \text { multilineata. } \\ \text { Bossiæa walkeri. } & \text { oppositifolia. } & \text { Melaleuca parviflora. } \\ \text { Casuarina stricta. } & \text { paisleyi. } & \text { Pittosporum phillyræoides. } \\ \text { Dodonæa attenuata. } & \text { rotundifolia. } & \text { Triodia irritans. }\end{array}$

THE PHYLLODIA IN SOME SPECIES OF ACACIA.

All species of Acacia which were studied in the field either bear phyllodia in the place of leaves or are aphyllous. Such organs show most clearly the impress of the subaerial environment. Naturally the response takes place along a variety of lines, but in a region of great aridity it has much to do with the water relation. This is revealed in devices of various kinds which lead to a conservation of water, but it is also shown in the relatively great formation of cellwalls, a direct result, as already pointed out, of a small water-supply. All of these features are shown well in various species of the genus Acacia, the leading characteristics of the structure of which are known. I shall point out, in the present paper, some of the most striking features in the structure of a few species which were found in the desertic-arid portions of South Australia and certain of which may not be generally known. Of the species $A$. aneura, continua, linophylla, tarculiensis, and tetragonophylla, all except $A$. continua and $A$. tarculiensis were found at Oodnadatta; $A$. continua was studied at Quorn, and $A$. tarculiensis was seen at Tarcoola, its type habitat. 


\section{A. ANEURA AND A. LiNophylla.}

The phyllodia of these species are long, in the latter species linear, although in one form those of $A$. aneura are rather broad. Only the narrow form in this species was examined. The structure of the phyllodia in the two species is so much alike that a characterization of that of one only, A. linophylla, will be sufficient. As figure 12 indicates, in cross-section the phyllode is oval with crenulate margin. Opposite the elevations of the latter is sclerenchyma which extends to the epidermis, and opposite the hollows are masses of chlorenchyma. The alternation of the two tissues gives rise to the striations characteristic of the phyllodia. The sclerenchyma masses reach to the conductive tissue, of whatever size or relative importance. There is also mechanical tissue on the inner sides of each of the fibro-vascular bundles. Longitudinal sections of the phyllodia show that the latter tissue is only in part fibrous, but that the portion placed near the epidermis is of short cells, cuboid in fact-that is, hypoderm. There is a relatively large amount of mechanical tissue. The chlorenchyma is composed of isolated strands, masses in section, of palisade cells which (as figure 14 indicates) are relatively narrow and long. On the inner side they abut on cuboid cells only, which separate them from the tracheæ of the conductive system. On the peripheral side they touch the inner wall of the epidermis where the latter is sharply infolded to form the furrows previously mentioned. The epidermis has relatively thin vertical and inner walls, and the external wall varies in thickness, being heavy on the ridges and relatively light in the furrows. It is in the latter only that stomata are to be found where they are situated on the inner portion of the sides as well as at the bottom. The stomata do not appear to have especial protective devices of and by them-

Explanations of Figures 12 to 21.

Fic. 12. Acacia linophylla, transverse section of phyllode, semi-diagrammatic, $\times 72$. The large proportion of mechanical tissue is indicated $(s c)$ and the protected position of the chlorenchyma $(\mathrm{ch})$. The relatively heavy covering of hairs is indicated by stippling.

Fro. 13. Same. Detail of margin of phyllode to show the nature of the sclerenchma and epidermal cells and the presence of glandular trichomes, $\times 700$.

Fro. 14. Same. Detail of inner portion of chlorenchyma showing its relation to the fibrovascular bundle at the left, $\times 700$.

Fra. 15. Acacia continua, transverse section of chlorophyll-bearing stem, $\times 52.5$.

FIG. 16. Acacia tetragonophylla, cross-section of phyllode, semi-diagrammatic, $\times 85$.

Fig. 17. Casuarina stricta, transverse section, semi-diagrammatic, of chlorophyll-bearing stem, $\times 72$. The chlorenchyma is shown partly protected by the heavy epidermis and partly by the furrows with the trichomes, of which the latter are not shown. The enlarged outer ends of the sclerenchyma also act in the same capacity.

Fig. 18. Eremophila alternifolia, detail of young stem with glandular trichome, $X 525$.

Fig. 19. Same. Tranoverse section of leaf showing old glandular trichome, heavy epidermis, and its covering of a resinous substance.

Fra. 20. Eremophila freelingii, semi-diagrammatic transverse section of leaf to show the size and frequency of internal glands $(g l), \times 52.5$.

Fra. 21. Eremophila rotundifolia, longitudinal section, semi-diagrammatic, $\times 52.5$, to show the relatively large internal glands and the very heavy covering of hairs $(t r)$.

In the figures the tissues are designated as follows: $c h$, chlorenchyms; fv, conductive tissue; $o l$, internal gland; $h d$, hypoderm; $8 c$, sclerenchyma. 

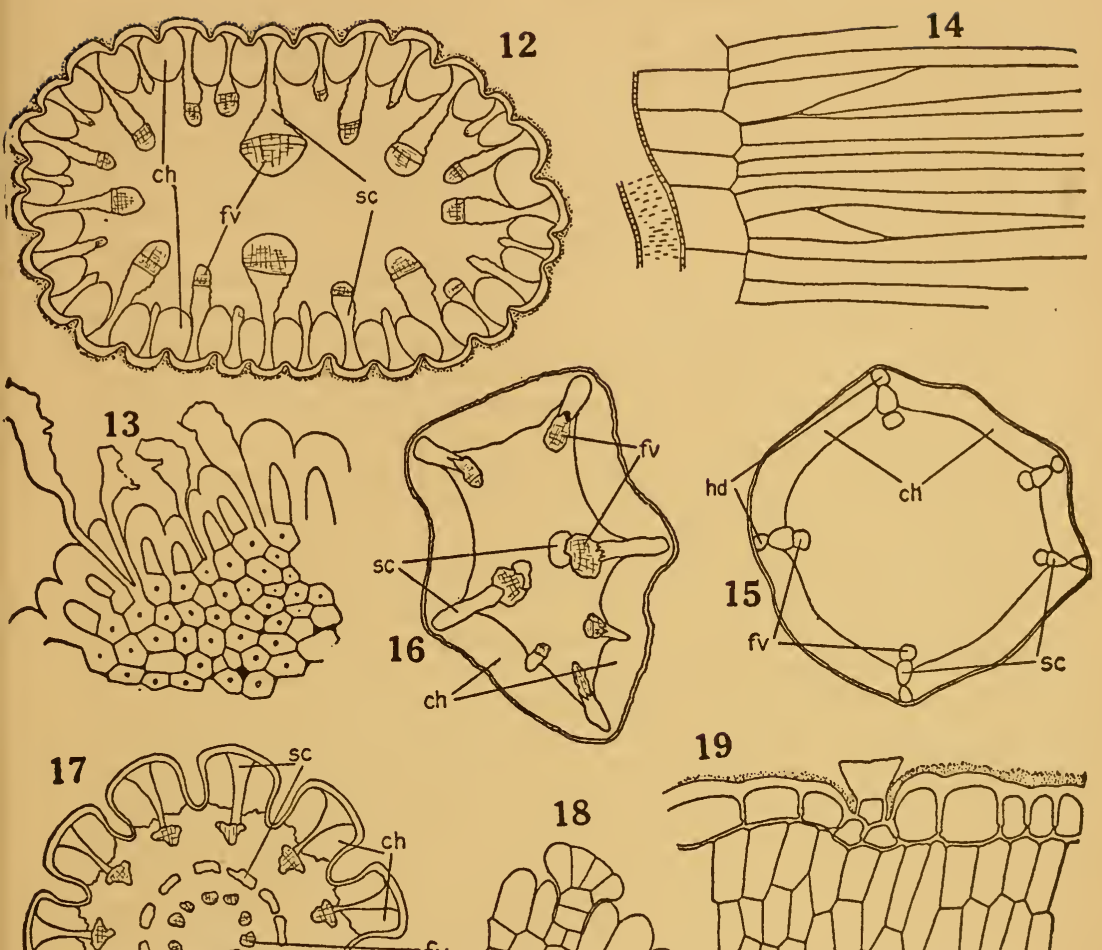

(5) 3000000 cons?

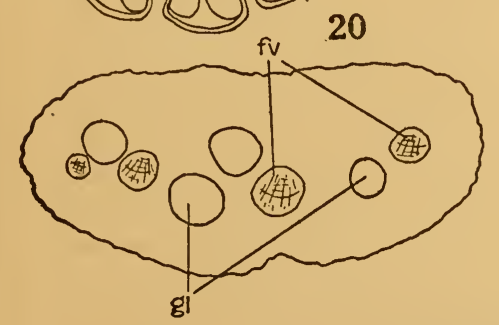

18
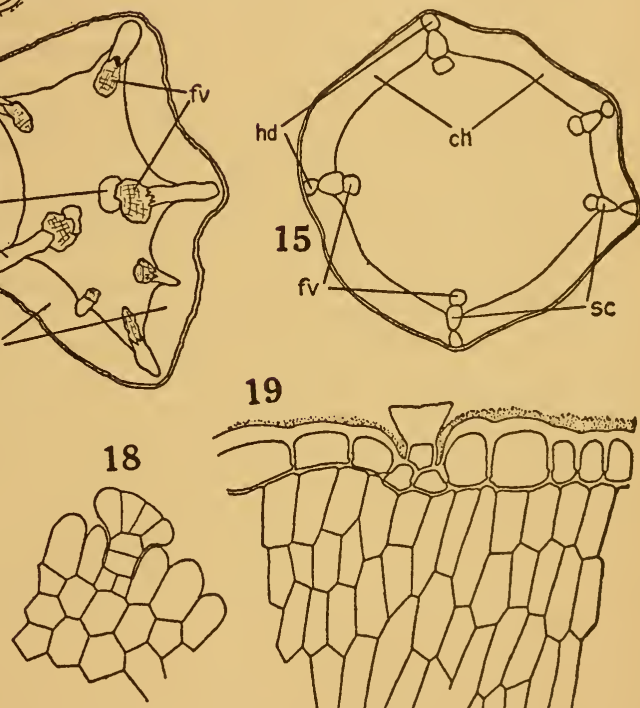

19
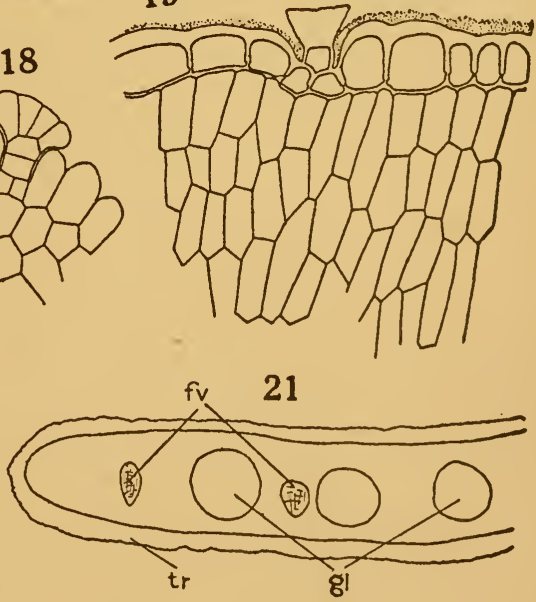

Figdres 12 to 21. 
selves, but their position, as well as the presence of trichomes, apparently suffices in this regard. The outer surface of the epidermal cells is sharply arched and trichomes of characteristic sorts, both glandular and protective, spring between these cells; the former have relatively widely expanded heads which collapse in age, and the latter are apparently only short, two-armed, giving an appearance much like a section of shield hairs. The glandular hairs are especially abundant.

\section{Acacia continua.}

According to Tate, Acacia continua is one of three species of the genus in South Australia which has neither leaves nor phyllodia. It is a shrub with short branches, 2.5 to $5 \mathrm{~cm}$. in length, which resemble spines. The species was observed at Quorn, where it occurs under fairly good conditions, so far as moisture is concerned.

A cross-section of one of the short branches is somewhat angular in outline (fig. 15). The general arrangement of the tissues is apparently about as in cylindrical phyllodia of other species. That is, there is a large central portion composed of chlorophyll-free parenchyma, a peripheral band of chlorenchyma, masses of sclerenchyma extending in from the angles, and an epidermis with a well-developed cuticle. Trichomes appear to be wholly wanting, and no secretion of any kind was seen to cover the epidermis. A leading departure from the usual condition to be found in phyllodia (which appears to be a quantitative variation, however) is in the development of tissue with especially heavy walls, either fibrous or otherwise. The hypoderm of the material studied was little developed, although it was regularly present; also, there is relatively little of the fibrous tissue between it and the more deeply placed fibrovascular systems. Finally, the cell-

\section{Explanations of Figures 22 to 31.}

Fig. 22. Fusanus acuminatus, fragment of leaf showing chlorenchyma and a group of tracheids, $\times 350$.

Fig. 23. Same. Cross-section of leaf to show the heavy epidermis consisting of two layers of cells, $\times 350$.

FIg. 24. Gravillea stenobotrya, semi-diagrammatic transverse section of leaf. The various tissues are as indicated. Trichomes and stomata are confined to the ventral side. $\times 52.5$.

Fig. 25. Same. Detail of leaf, dorsal side, in cross-section to show the greatly elongated epidermal cells and well-marked palisades, $\times 350$.

Fig. 26. Hakea leucoptera, leaf fragment, in transverse section, with very heavy epidermis and deeply sunken stoma and papillate processes in stomatal canal. The presence of sclerenchymatous fibers in the palisade chlorenchyma is shown. $\times 350$.

Fro. 27. Hakea multilineata, semi-diagrammatic cross-section of leaf. The prominent development of mechanical tissue and dorsiventral nature of the leaf structure are indicated. $\times 52.5$.

Fic. 28. Same. Fragment of leaf, cross-section, to show heavy epidermis, deeply sunken stoma, and pronounced palisade character of the chlorenchyma, $\times 350$.

Fig. 29. Pittosporum phillyraoides, fragment of dorsal side of leaf, transverse section, to show the 2- or 3-layered epidermis, $\times 350$.

Fro. 30. Same, ventral side of leaf. The heavy outer epidermal wall, the single cell layer of the epidermis, and the superficially placed stoma are indicated. $\times 350$.

Frg. 31. Triodia irritans, transverse section of leaf, semi-diagrammatic, showing its infolded condition and the position and relative abundance of the main tissues, $\times 85$.

The tissues are designated as follows: $c h$, chlorenchyma; $e p$, epidermis; $f v$, fibro-vascular tissue; so, sclerenchyma. 
ARID PORTIONS OF SOUTH AUSTRALIA.
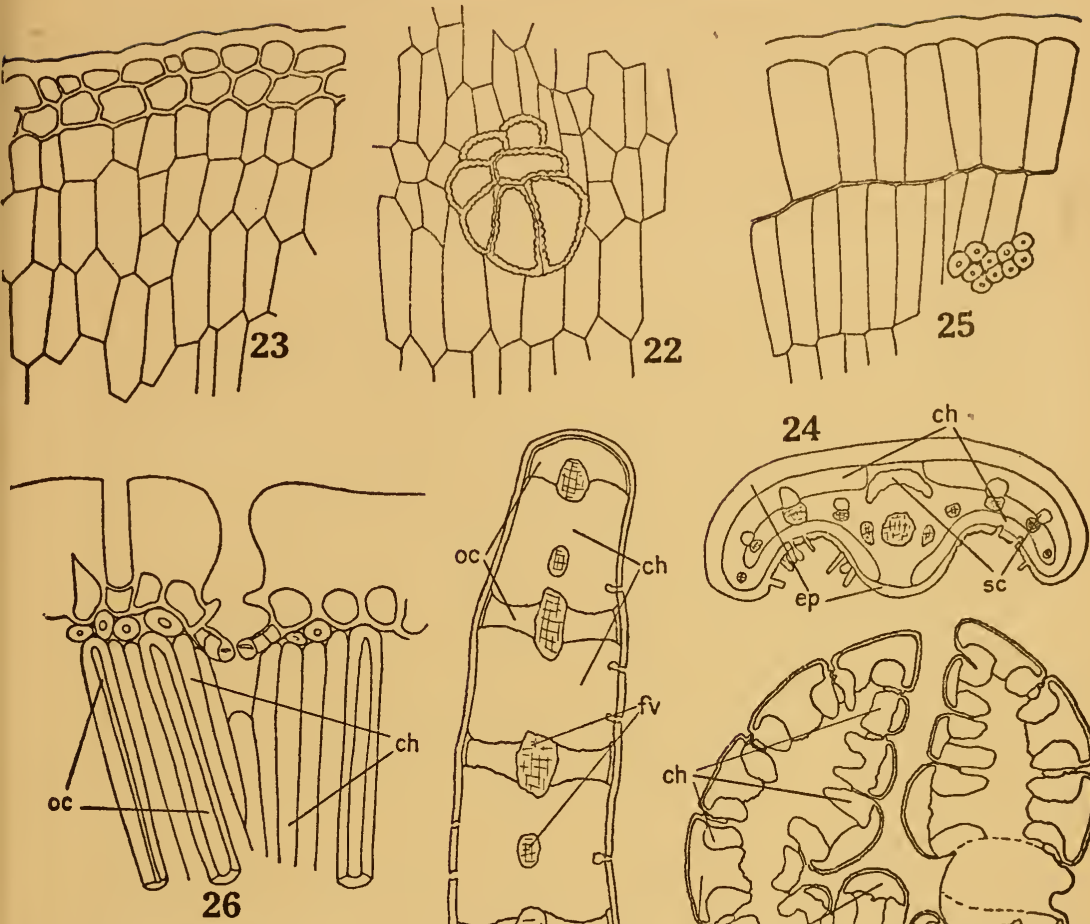

(1)

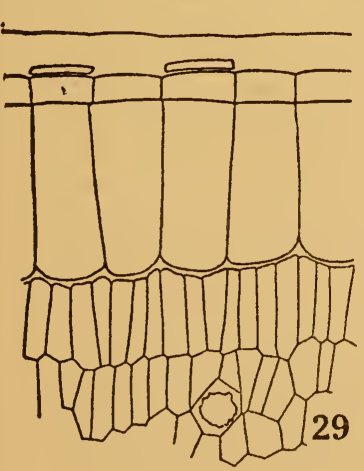

29
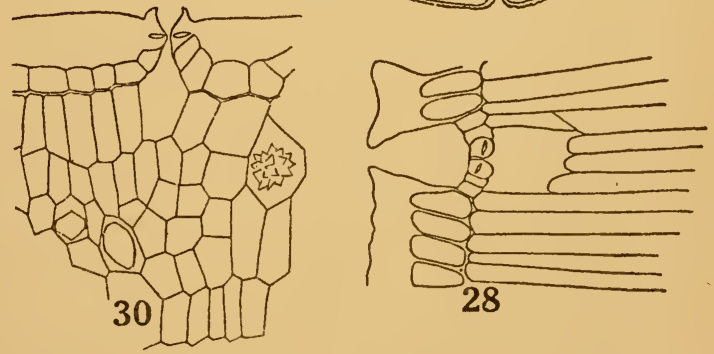

Frgures 22 to 31. 
walls of the innermost central parenchyma are thin. The material examined appeared to be mature, and if so, the lack of sclerenchyma in quantity is a noteworthy feature of the structure of the species.

\section{ACACIA TARCULIENSIS.}

Acacia tarculiensis is a shrub of compact habit of growth. The phyllodia are broad and numerous, so that the transpiring surface is very considerable. This is in marked contrast to $A$. aneura and $A$. linophylla, as will be perceived.

The phyllodia of $A$. tarculiensis are of a steel-blue color and the margins have a distinct line of dark brown. In transverse section the following are the most striking structural features: Chlorenchyma and sclerenchyma alternate beneath the epidermis, the former lying mainly but not wholly in the shallow hollows of the wavy margin of the section. The bands of supporting tissue are narrow and the cell-walls are not so well developed as in the two species above referred to. The outer epidermal wall is fairly heavy. The guard cells of the stomata are deeply placed and thus are at the bottom of short tubes composed largely of the thickened outer walls. The chlorenchyma is composed of two rows of rather narrow cells which abut on chlorophyll-free parenchyma, which in turn is situated next to the conductive elements. The latter lie at about the same distance beneath the surface of the phyllode and thus inclose the greatest single portion of the tissues, namely, the chlorophyll-free interior parenchyma, which is made up of relatively large cells.

Trichomes of whatever sort do not appear to be a feature of the phyllodia "blades" or lamina. On the "blades" of the older phyllodia only very widely scattering remains of trichomes are to be found. These appear to be of two kinds only, namely, a short-stalked and small secreting hair and a larger and two-armed covering hair. The material did not show the hairs to advantage, but suggested that they are not plentiful. The most striking trichomes of the phyllodia, however, are to be found only along the margins and are composed of chains of cells, the terminal one being the largest, all of which, in the herbarium material studied, are dark brown in color and appear to be secretory. The outer edge of the blade of the phyllode is covered heavily with a nearly colorless material, the nature of which I did not attempt to learn, but it gave evidence of having originated in the hairs. It is probable, therefore, that the trichomes are glandular. The origin of the hairs was not determined. The tissues immediately beneath these hairs, to a depth of 3 to 4 cells, is discolored in a fashion analogous to that of the hairs themselves. The cells are otherwise colorless, small, and have a curious appearance of being in the process of division on a plane parallel to the leaf margin. A noteworthy strand of conductive tissue underlies the marginal tissue just referred to. 
Acacia tetragonophylla.

In Acacia tetragonophylla the phyllodia are needle-shaped and short. Moreover, in especially dry habitats or during dry seasons they may be largely shed, thus reducing the transpiring surface. An analogous condition was observed in $A$. colletioides, having similar phyllodia, at Ooldea. On the other hand, where the environment is relatively moist, as in certain habitats at Copley, the phyllodia appear to remain for several years.

The leading features of the structure of the phyllodia of the species (fig. 16) include prominent masses of sclerenchyma, a part of which project outward from the conductive tissue to the epidermis, and a part between it and the central parenchyma, the central non-chlorophyllous parenchyma, and the masses of chlorenchyma which lie exterior to the latter and between the peripherally placed sclerenchyma. The cuticle is fairly heavy. No trichomes or resinous secretion were observed. Thus there appears to be a striking absence of certain features clearly related to the extremely arid environment in which the species occurs. However, the fact that the phyllodia are of small size and fall away readily may be a reasonable explanation of this condition. The relatively large proportion of cells with heavy walls is, as has already been referred to, a direct expression of immediate effects of an arid environment and is not related directly to the storage or to the husbanding of the water-supply. 


\section{NOTES ON CERTAIN OTHER SPECIES OF THE REGION.}

\section{BosSIEA WALKERI.}

This is a low shrub of rather loose habit of growth and leafless. The branches are flattened, almost winged. The species was observed in the neighborhood of Ooldea, where it occurs mainly on dry, sandy ridges.* A cross-section of a stem shows the peripherally placed chlorenchyma, which is fairly distinctly grouped and made up of a short form of palisade cells, three layers or so in thickness, and, within the chlorenchyma, the central portion of the stem of which is largely composed of parenchyma, much of which was seen to contain starchlike granules. A leading feature of all the parenchymatous tissue is the relatively heavy walls, which are pitted. Sclerenchyma occurs in connection with the conductive tissue and is most abundant at the central portion of the stem, although large and conspicuous masses are to be found not far beneath the stem margins. The epidermis is made up of relatively deep cells, with a heavy cuticle, and is underlaid by a subepidermal tissue, very regular in appearance, and composed of rectangular cells placed at right angles to the stem surface and which may or may not contain chlorophyll. A cross-section of the stem shows that the surface is not plane but ridged. The stomata appear to be confined to the bottom of the furrows between the latter. They are situated somewhat below the general surface of the stem, therefore, and the guard cells are protected by a fairly heavy cuticular development. No trichomes of any kind were found on the material studied.

\section{Casuarina stricta.}

The equisetum-like branches of Casuarina stricta, which carry on the leaf function, have an intricate structure which appears to correspond in the essential points to that of $C$. equisetifolia as described by Solereder (1899:885). Only certain features, clearly associated with the xerophytic habit of the species, need for that reason be referred to in this place. The structural arrangement is intimately associated with the presence of longitudinal grooves and ridges characteristic of the "internodes" (fig. 17). The chlorenchyma, palisade tissue, is confined to the sides of the grooves, and in cross-section of the stem it appears as separate masses. Between the chlorenchma, and between it and the periphery of the stem, there is only or mainly sclerenchyma. Stomata are confined to the sides and bottoms of the grooves. Trichomes are present in the grooves, from the bottom of which they take their origin. The inner portion of the chlorenchyma is only slightly more deeply placed than the bottom of the grooves. A distinct celllayer, endodermis, bounds the inner face of the chlorenchyma.

Cortical conductive tissue lies opposite the ridges and hence somewhat deeper than the chlorophyll-bearing tissue, but on a line sepa- 
rating that of each ridge. On either side of the last, and joining it with the endodermis, are water-storing tracheids, which, however, are not especially well developed in the material of $C$. stricta studied. Within the latter there extends around the periphery of the central cylinder a ring of sclerenchyma which appears to be of a twofold nature, the inner portion at least being fibrous, but this does not appear throughout the entire "internode." Usually within the zone of the cortical conductive tissue is found that of the central cylinder, the separate fibro-vascular bundles of which alternate with the ridges and hence are opposite the furrows above referred to, and alternate with the cortical conductive tissue. Some sclerenchyma appears with the separate bundles of conductive tissue in the central cylinder. A fairly thick-walled parenchyma constitutes the ground tissue of the stem.

The leading points of interest in connection with the structure of the stem, from the present point of view, can be said to be very perfect protection against rapid water-loss afforded by the outer cortex with its heavy development of sclerenchyma, the fairly deep and narrow furrows with protective trichomes, the presence of stomata in the furrows only, and the close association of chlorenchyma and the waterconductive and water-storing tissue of the cortex. These morphological features, taken in connection with the great reduction in the exposed surface, point to very perfect adjustment to an environment in which a rather poor water-supply is associated with an atmosphere. which has a low moisture-content much of the year.

\section{Dodonza attenuata and D. Lobulata.}

The leaves of Dodoncea attenuata have distinct dorsal and ventral sides. They are of fair size and do not have so marked a xerophytic appearance as most of the other species of perennials examined. This characteristic is carried out in the structure as well. A cross-section of the leaves shows a bifacial arrangement of the chlorenchyma. That on the dorsal side is distinctly palisade and that on the ventral side is well-marked spongy parenchyma. Stomata are on the ventral surface only where they either lie on a level with the leaf-surface or in some instances they were seen to project slightly above it. The epidermis is not heavy. The outer walls arch outward somewhat. Sclerenchyma is to be found in association with the large conductive tissue which constitutes the "midrib" of the leaf, and in no other place. Shortstalked, multicellular, shield-shaped trichomes are sparingly present on both leaf-surfaces. The trichomes have the appearance of being glandular, yet no resinous or other substance was found on the leafsurface contiguous to them in the material examined; but in young leaves the surface is highly polished, as if lacquered, and it is probable that the substance is a secretion derived from such trichomes.

The structure and the more superficial appearance of the leaves of Dodoncea lobulata are quite unlike those of the species just described. 
The leaves are small, linear, or linearcuneate. They are well coated with some substance, probably resinous, which causes them to glisten in the light. This is to be found on both sides of the leaves. An examination of the leaf-structure shows that the two sides of the leaves are nearly alike, if not wholly so. The chlorenchyma consists of palisade tissue which is similar on the two sides. Stomata occur on both dorsal and ventral surfaces as well as on the leaf edges. They are somewhat elevated above the general level of the leaf, especially in the young leaves, in which the leaf-margin, in cross-section, is somewhat crenulated. Squat, shield-shaped trichomes occur on both leafsurfaces. These are multicellular and probably glandular, although they were so few in the material examined that it is difficult to think that the resinous covering of the epidermis was wholly derived from them, especially in view of the fact that the secretion is very equally distributed over the leaf-surface and is no heavier near the hairs than at some distance from them. No sclerenchyma was found in the leaves of this species.

\section{SOME MORPHOLOGICAL FEATURES OF THE GENUS EREMOPHILA.}

The species of Eremophila must be considered among the most interesting and in certain particulars among the most remarkable of the xerophytic perennials of South Australia. They occur in the drier portions of the state, to which for the most part they are confined. The species are shrubs or small trees and nearly all of those seen bore a relatively large leaf-surface. To the last statement, however, there are striking exceptions, among which should be included Pholidia (formerly Eremophila) scoparia, not to mention others. Certain of the species, notably $E$. neglecta, appear to be confined to the desert, although others, as $E$. brownii, occur in the arid and semiarid regions as well. There are apparently no special water-storage organs, and so far as known the root-system does not present special characters. In several of the species, however, as will appear below, there are various morphological features which look to the conservation of water, once it is taken into the plants. When in bloom many of the species are of striking beauty.

According to Solereder (1899:706), who summarizes the earlier work on the Myoporineæ, there are structural features of interest in species of Eremophila. Thus, the leaves and the stems have "Sekretenlücken," internal glands, which I am calling glandular pockets, as well as glandular hairs in several species. Indeed, such are wanting in $E$. longifolia only. Glandular hairs appear generally to be present and to vary somewhat in form, size, and structure. The other type of trichome, a "covering" hair, according to Solereder, is even more variable. It may consist of a single row of cells which may be branched 
or aggregated into a sympodial type, or it may be a "water-storage" hair, type not given, or a disk hair with multicellular flattened head. Stomata occur on both surfaces of the leaves. Strictly bifacial leafstructure does not occur in Eremophila.

Apparently much of the work referred to by Solereder was based on herbarium material. In the present study, also, it has been necessary to rely on such material. The following species of Eremophila were observed by the writer at the places named and were subsequently examined:

At Oodnadatta:

E. alternifolia.

brownii.

freelingii.

latrobei.

longifolia.

neglecta.

oppositifolia.

paisleyi.

rotundifolia.
At Copley:

L. alternifolia.

brownii.

freelingii.

latrobei.

longifolia.

At Quorn: oppositifolia.

E. brownii.

oppositifolia.
At Tarcoola:

E. latrobei. paisleyi.

At Ooldea: rotundifolia.

E. alternifolia.

Although the list comprises all of the genus that were seen at each of the places named, it does not preclude the possibility that others may have been at each station as well. It will be seen that $E$. brownii is fairly widespread, while others, as $E$. rotundifolia, paisleyi, and especially neglecta, have a limited distribution. No species of the genus, however, appears to occur outside of the desert-arid or semi-arid regions.

In addition to the species of Eremophila as at present understood, the study includes Pholidia scoparia, formerly classed under the genus Eremophila. This species has a greater range than any of those given in the above list and occurs where the rainfall is fairly good as well as where it is relatively small in amount.

An examination of the leaves of the different species of Eremophila shows not a little diversity as to several morphological features, among which are the conditions of hairiness, the character of the trichomes, the size, the plentifulness as well as the presence of internal secretion glands, the character of the epidermis, the position and other features of the stomata, and, not to extend the list, the character of the subepidermal tissues. There are also apparent, possibly real, correlations between several of these features which are of interest.

Resinous secretion organs occur either as hairs or as pockets deeply embedded in the tissues of leaf or stem. In the leaves the pocket glands are usually in the mesophyll, although the position is not constant. They are to be found only in the primary cortex of stems. The origin of these internal secreting reservoirs, for such they appear to be, is apparently in dispute. It is maintained on one side that they are schizogenous and on the other that they arise through the breaking 
down of cell-walls. But according to Solereder, inasmuch as the secretion reservoirs are surrounded by an epithelium several cells in thickness, the innermost walls of which ultimately become dissolved, freeing the resinous substance, the gland is to be considered as being schizolysigenous. Pocket glands of this character were found in all of the species of Eremophila examined except $E$. longifolia, thus supporting the results of von Bokorny (Solereder, 1899:706). Glands of this kind were not seen in the stems of $E$. oppositifolia in the material available for examination by me, but they should be expected to occur in them as long as they have been surely found in the leaves.

The glandular trichomes exhibit some variation as between different species. They may be either short, as they usually are, or have a stalk of several cells. The heads may either be flattened or somewhat elongated. The glandular hairs of $E$. neglecta and of $E$. freelingii are of the former, and those of $E$. rotundifolia are of the latter type. Glandular hairs were found in all of the species examined except $\boldsymbol{E}$. longifolia, $E$. oppositifolia, and Pholidia scoparia. So far as the resinous secretion of the hairs is concerned, it was seen to be more or less abundant on the leaves and stems wherever the hairs were to be found, but only in $E$. freelingii was it found to be copious. In specimens of this species from Oodnadatta, and especially on the stems, the resinous exudation was so abundant as to quite cover the glandular hairs themselves. It was also present in large amount on the leaves.

Stomata were found on both sides of the leaves of all of the species examined. In most cases they were flush with the leaf-surface. However, in the leaves of such as had a heavy covering of hairs, as for example in $E$. rotundfolia, the guard-cells projected somewhat. It was noticeable, also, that a similar condition obtained in $E$. freelingii, where the resinous coating of the leaf was heavy. In either instance it is apparent that this superior position of the stomata is directly related to the heavy protective cover of the leaf.

A heavy cuticle was found to be present on the leaves of most species, but it is heavier in some than in others, and this feature is usually correlated with the presence, or absence, of a resinous covering or one of trichomes. Where such is largely or wholly absent, as in $\boldsymbol{E}$. brownii, alternifolia, and paisleyi, the cuticle is especially heavy. In the case of the last two species the cuticle is so heavy that it brings about a rigid condition of the leaf itself. In the case of $E$. rotundifolia, however, where the hairy leaf-covering is particularly heavy, as will be mentioned below, the cuticle is very light.

The structure of the leaves is generally, although apparently not exclusively, dorsiventral. Thus, palisade cells are usually to be found on the dorsal and not on the ventral side. In Pholidia scoparia, Eremophila latrobei, $E$. longifolia, $E$. paisleyi, $E$. alternifolia, and $E$. oppositifolia, however, either palisade cells similar in appearance 
are on both sides of the leaves, or there is but little difference between the dorsal and the ventral sides in this regard. The leaf-structure of $E$. rotundifolia is also dorsiventral. In this species there is no wellmarked palisade, but fairly small cells, somewhat elongated in a direction at right angles to the leaf-surface, constitute a distinct stratum on both sides of the leaf. The cells of these strata have the appearance of palisade cells which have undergone division by cross-walls subsequent to the formation as such, but this procedure probably did not take place. A somewhat similar condition, but not so noticeable, is to be seen in E. neglecta. As will appear presently, only in Pholidia scoparia and in Eremophila longifolia, of the species having welldefined palisade tissue, is there a covering of hairs. In the latter species the covering is sparse and in the former it is of a peculiar type and not heavy. The correlation between leaf-cover and the presence of palisade tissue and the dorsiventral condition of the leaf apparently breaks down in $E$. oppositifolia, which has both of these features, the cover hairs being present in abundance. It was noted, also, that the walls of the epidermis of the species were heavy. All of these features might point to the need of relatively good water-relations of the species. but this remark needs further observation to substantiate it.

The cover-hairs are various. In $E$. freelingii they consist of a single row of cells with fairly heavy walls. The cover-hairs of $E$. brownii appear to be only of this kind, although Solereder states that branched trichomes occur in the species. Both the simple and the branched types of cover-hairs were found in $E$. neglecta stems, although only the former, and that sparingly, occur on the leaves of the species. In $E$. alternifolia (fig. 18) and rotundifolia these were no proper trichomes of either kind above described, but the epidermal cells of the young stems, and not of the leaves, project as short papillæ. In $E$. neglecta there appear to be such papillate cells also, but not to the exclusion of cover-hairs and not in abundance. In the two species mentioned such epidermal cells are wanting in the leaves, nor are coverhairs present. It is possible, therefore, that the papillate cells may be considered as simple cover-hairs. The leaves and stem of Pholidia scoparia bear shield-shaped trichomes which generally have a short stalk and are closely pressed to the leaf-surface. In young leaves and stems, at least, they overlap and form a very perfect cover.

\section{Fusanus acuminatus.}

The leaves of Fusanus acuminatus are fairly large, narrow-lanceolate, and rather thick. There appears to be no structural difference between the dorsal and the ventral sides. The following may be said to be the most striking structural features of the leaves: The chlorenchyma consists of relatively short palisade cells which maintain this character throughout. Crystals are to be found scattered through the 
mesophyll. There is little mechanical tissue, and what there is consists of cells with prominent lumen, both in connection with the conductive tissue and at the leaf margins. The epidermis is made of two celllayers of which the walls are fairly heavy. Stomata occur on both leaf-surfaces. An additional feature may be mentioned, namely, the presence of tracheids apparently independent of the regular conductive tissue (fig. 22). Very possibly they may be considered to have the capacity of storing water, as in instances which are well known.

\section{Gravillea stenobotrya.}

The leaves of Gravillea stenobotrya are narrow-linear and placed upright on the branches. They have unlike dorsal and ventral sides which are apparently subject to quite similar conditions of light and evaporation. A cross-section of the leaf shows certain striking structural features (fig. 24). The leaf margins are in-rolled, giving a rounded dorsal and a channeled ventral aspect. On the dorsal side the epidermis is especially heavy, owing to the great length of its component cell, and the cuticle also is heavy, but on the ventral side the epidermis is not heavy and the cuticle is light. Few if any trichomes occur on the dorsal surface, while the ventral side is heavily clothed with hairs, all apparently of the two-armed type figured and described by Solereder (1899:803). Stomata are confined to the ventral side. The chlorenchyma is heavier on the dorsal than on the ventral side. Sclerenchyma is associated with the conductive tissue, but is not especially abundant. The ground tissue in the material studied appears to be of a fairly loose structure and is not heavily walled.

\section{Hakea multilineata and H. LeUcoptera.}

The leaves of Hakea multilineata are long, narrow, and placed in a vertical position on the shrub. They are striate and have a very tough texture. A cross-section shows that the two sides are similar (fig. 27). The following are the most striking structural features of the leaves: The chlorenchyma extends from side to side. Separating the chlorenchyma into strips are ribbons of sclerenchyma which reach from the fibro-vascular bundles of the middle portion of the leaf to the epidermis of either face. The sclerenchyma appears to be mainly or wholly fibrous. The chlorenchyma is composed of relatively long and narrow palisade cells. The epidermis is heavy and has a heavy cuticle. The stomata are situated at the level of the inner epidermal walls and hence at the bottom of pores made by the thickened outer portion of the epidermis (fig. 28).

In $H$. leucoptera the leaves are cylindrical, with the end tapering to a point, hence the common name "needle" bush. The chlorenchyma forms an uninterrupted band beneath the epidermis. The central portion of the leaf has scattering bundles of conductive tissue, each with its accompanying mass of sclerenchyma on opposite sides, and all surrounded by a fairly heavy walled parenchyma. The 
effect is as if the mechanical tissue referred to were embedded in the parenchyma, as in fact it is. At the periphery of this centrally located cell-mass are separated hard-bast fibers which resemble the palisade cells of the chlorenchyma in diameter and usually in length, and which extend through the chlorenchyma to the epidermis (fig. 26). Although these fibers occasionally extend well into the centrally placed tissue, they nevertheless are almost wholly confined to the chlorenchyma. The fibers also are usually simple and not branched. In these two particulars they appear to be unlike the sclerenchyma of a similar nature described by Jönsson and referred to by Solereder (1899:801), in. which branching occurs, and which is generally scattered throughout the leaf.

The epidermis is unusually heavy, owing to the greatly thickened cuticle. The stomata are placed on a level with the inner wall of the epidermis and are thus at the bottom of a chimney-like structure composed of the epidermis, mainly of the cuticle (fig. 26). At the inner portion of the stomatal pore, and immediately above the stomata, are thickened papillæ of cell-wall material; these fairly well close the bottom of the stomatal pores (fig. 26).

In the mature leaves, both of $H$. multilineata and of $H$. leucoptera, there do not appear to be trichomes of any kind, but the remains of hairs are occasionally met with, showing that when young the leaves are provided with them. In the last figure referred to, the position of a trichome is indicated by the indentation to the left of the stomatal pore, brought about by the failure of cuticle to form where the hair was situated. An additional note should be made on the stomatal pores. In the material studied there often appear to be pores which are continuous with one another, with the effect that a stomatal chamber containing more than one pore is formed.

\section{Melaleuca parviflora.}

The leaves of Melaleuca parviflora are short and narrow, being about $1 \mathrm{~mm}$. in width and $9 \mathrm{~mm}$. in length. A transverse section of the leaves shows the following leading structural features: There is a well-defined chlorenchyma, consisting of narrow and fairly long palisade cells, which is similar on both leaf-sides. The leaf interior is composed mostly of chlorophyll-free parenchyma, of good size, which has fairly thick walls and no or few intercellular spaces. Sclerenchyma is to be found associated with the conductive tissue only, and it is not a conspicuous feature. The epidermis has a fairly thick outer wall. The stomata are on both leaf-surfaces and lie at the bottom of pores made of the thickened cuticle of the epidermis.

\section{Pittosporum phillyraoides.}

Theleaves of Pittosporum phillyrooides are linear-oblong, about $8 \mathrm{~mm}$. in width and $120 \mathrm{~mm}$., more or less, in length. The small tree is well covered with them, so that the evaporation surface is not inconsiderable. 
There is a distinct bifacial structure of the leaves of this species of Pittosporum. The stomata are confined to the ventral side. The chlorenchyma of the dorsal side is more consistently of palisade cells than is that of the other. The stomata are on a level with the epidermis. Crystals are fairly numerous in the mesophyll. A relatively small amount of sclerenchyma, not well developed, is to be found in connection with the main conductive tracts and on the leaf-edges. But the most striking feature of the structure of the leaves is the presence of an epidermis on the dorsal side, consisting of more than one cell-layer. The outer epidermal cells are approximately one-fifth as deep as the underlying epidermal cells, and these are occasionally accompanied, as shown in figure 29 , by narrow cells which appear to be situated in their outer walls. The two-celled condition of the epidermis continues around the edges of the leaves, and a few epidermal cells on the ventral side may be of two layers. On both ventral and dorsal surfaces the outer epidermal wall is very thick, and the inner walls of the epidermis on both leaf-sides are also somewhat thickened (fig. 30).

\section{Triodia IRritans.}

The occurrence of Triodia throughout the driest portion of the interior of the continent, characteristically in sandy habitats, makes the structure of especial interest. T. irritans is a "bunch" grass, with fairly rigid, sharp-pointed leaves. It is sometimes called "porcupine" grass, which aptly suggests its nature.

A cross-section of a leaf of Triodia is nearly circular in outline. This is due to the in-rolling by which the ventral surface comes to lie within, and only the dorsal surface is presented to the outside (fig. 31).

On the dorsal outer as well as the inner surfaces are several deep furrows, giving the leaf-surface a convoluted effect. The chlorenchyma is segregated on either side of the furrows, so that in section the chlorophyll-bearing tissue occurs in separate masses. Sclerenchyma constitutes a very prominent part of the tissues of the leaf. On the dorsal side it reaches to the epidermis and extends to about the depth attained by the chlorenchyma, and on the ventral inner side it also reaches to the epidermis but does not occupy much of the spaces between masses of chlorenchyma, which is filled in with parenchyma having fairly heavy walls. The outer epidermal wall is heaviest in the furrows, but is not especially heavy elsewhere. Trichomes are present sparingly on the in-rolled surface and short hairs close the narrowed "throat" of the furrows. Stomata are small and confined to the portion of the furrows opposite the chlorophyll-bearing cells, and are present, but not in abundance, on both leaf-surfaces. 


\section{CERTAIN REACTIONS AND ADJUSTMENTS OF PLANTS OF THE MORE ARID PORTIONS OF SOUTH AUSTRALIA.}

Any conception of the nature of the reactions of living plants to their physical environment, as, for example, to any particular feature of their environment like the oxygen-supply or that of water, has to deal with factors widely different from a simple or direct reaction in which non-living substances only take part. Aside from and in addition to the chemical complexity of the living organism, the feature of its heredity must be taken into account. This, to put it in simple terms, merely means in the course of its phylogeny the organism has for untold ages reacted to its environment, so that the living plant, which to-day occupies its place in the desert, is in itself a resultant, so to speak, of all of the reactions of its long past. One of the results is that living plants with unlike histories, in the sense above used, may react along different lines to a certain extent, according to the direction of the development they may be taking. But in the present study only existing plants and the present-day environment are taken into consideration, and the following paragraphs give some of the most striking reactions of the plants to their environment. Other reactions are referred to in the course of the paper.

\section{Reactions to Light.}

Among the possible reactions to light may be mentioned the vertical position assumed by the chlorophyll-bearing organs of many or most perennials of the drier portions of the state. This is attained in part by an upright position of the branches, but mainly by a vertical position taken by the individual organs themselves and in a measure independent of the position of the branches which bear them. In Hakea multilineata, Gravillea stenobotrya, and Acacia linophylla, to mention no others, the vertical position is attained because of the upright habit of the leaves, and in Pittosporum phillyrooides and Eucalyptus spp. it is attained by their dependence.

The presence of a heavy epidermis, or of a covering of trichomes, or of resinous substances, or the elongation of the cells containing chlorophyll bodies in a direction at right angles to the surface of the leaf, may all (in part at least) be related to an adjustment of the organ to the intensity of the light. The evidence for certain of these conclusions, it must be said, is merely inferential. For example, in Eremophila rotundifolia the leaves have a heavy covering of trichomes, and in them the palisade cells are poorly developed. The palisades appear to be about the same in $E$. neglecta, in which species there is a heavy epidermis with glandular hairs and with a marked resinous coating.

Whether, however, the light-screen of whatever kind is a cause or effect is another question, and the observations throw no light on its solution. The interactions and interrelations are so complex that 
their disentanglement is not without its difficulties. For example, in Triodia irritans the large development of mechanical tissue, as will appear below, is probably directly related to the physical and chemical effects of dryness, but the position of this tissue in the leaves is such that it becomes a very effective light-screen for the chlorenchyma, which is not of palisade cells, of the leaf. And from the last circumstance it might be considered to be closely associated in some way with the light relations of the plant-which indeed may be the case, but this remains to be proved.

\section{Reactions to Temperature.}

The most apparent reactions of the plants to temperature have to do with the recurrence of vegetative growth and of activities associated with the formation of flowers and fruits. But also the general distribution of plants, particularly the north-south distribution, is largely dependent on temperatures. Often, also, local distribution, especially aspect "preference," is directly related to the same as well. Aside from these well-known reactions, which are of great importance, few appear to have been definitely established. Temperature is effective indirectly, however, in that it is directly related to the relative humidity of the air and may greatly affect the moisture-content of the soil as well. Slopes, therefore, which receive the most heat may also be the most arid both as regards the soil and the air. The effects of temperature on various chemical processes in the plant have already been referred to and need not be summarized in this place.

\section{Reactions to a Small Water-supply.}

A reduction of the leaf-surface is the most noticeable effect on the perennial plants of a small water-supply with its direct accompanying physical features, a low relative humidity of the air, and a rapid rate of evaporation. This reaction is shown in several ways. Trees are usually small and symmetrical. The "canopy" form of such of the Eucalyptus species as have a facultative "mallee" habit more especially, of which $E$. oleosa is an example, illustrate this, although it can be seen at every turn in the drier portions of South Australia. Where the species grow by streamways the habit of growth is usually noticeably less compact. Often, usually in the drier regions, the foliage is confined to the tips of the branches, by which the canopy effect is heightened. The immediate effect on the plants, however, is to limit the growth of the leaves or to bring about such a modification of the chorophyll-bearing organs as is to be witnessed in many acacias, or to wholly suppress the formation of leaves in mature plants. During this process the foliar organ apparently undergoes an alteration in form, so that it becomes relatively long as compared with what may be supposed to be the ancestral condition, or that of plants more favorably situated as regards the water-supply. This observation was directly confirmed by numerous measurements and 
indirectly by a possible reversion of the phyllodia of Acacia pycnantha, for example, which are relatively large. This species apparently requires relatively good water-relations.

The vertical position assumed by the foliar organs of shrubs and trees in the dry regions is perhaps mainly due to a reaction to conditions accompanying a small water-supply, although possibly there is here, as mentioned above, a light-relation of moment. Among the species having this characteristic especially well developed are Hakea multilineata, Gravillea stenobotrya, Acacia linophylla, A. tarculiensis, Pittosporum phillyrcoides, and Eucalyptus spp.

A frequent accompaniment of a condition of dryness in the environment, and possibly often directly related to it, is the presence of a covering of trichomes which serves the end of protecting the foliar organs against excessive evaporation, as well as against intense illumination. The trichomes are of two general kinds, those which serve merely as a covering and those which are glandular. A heavy covering of the former usually produces a gray-green effect. Among species having such a trichomal covering well developed are Acacia linophylla, Eremophila longifolia, $E$. oppositifolia, and E. rotundifolia. In certain species, as in Gravillea stenobotrya, the (mature) leaves have a covering of hairs on the ventral surface only, and in other plants with furrows in the leaves or phyllodia such trichomes may be confined to the furrows, as in Casuarina sp. and Triodia irritans, at least in the mature organs.

Glandular hairs are frequently observed. They are numerous, for example, in Acacia linophylla, Casuarina stricta, and Dodoncea sp., but may possibly be found in most perennials of the dry regions, at least in the young stems and leaves, or their equivalent. In Acacia tarculiensis may be seen what appears to be glandular trichomes, but they are restricted to the margins of the phyllodia.

The formation of resinous secretions and secretions of oil, etc., by glandular trichomes as well as by internal glands, is of frequent occurrence in plants of the drier regions. It is possibly in some way directly related to the dryness of the environment, although in exactly what way seems doubtful. Internal glands occur in the Myrtaceæ, as is well known, but may be found in other families, as for example, in the Myoporineæ. In several species of the genus Eremophila of the family last named, internal secretion-glands were seen in the leaves and in the cortex of the young stems.

Other morphological features also are apparently mainly associated with the occurrence of the species under dry climatic conditions. In all or nearly all species of perennials, for example, the epidermis is very heavy. This is usually brought about by the great thickness of the outer wall, which is probably always cutinized, but in Pittosporum phillyrcooides and Fusanus acuminatus the epidermis is in part or altogether of two or more layers of cells. On the dorsal side of the leaves of Gravillea stenobotrya the epidermal cells have unusual length. 
Usually the lateral walls as well as the internal wall of the epidermal cells are considerably thickened.

A structural characteristic of note in marked xerophytes is the prominent development of cell-walls or of tissue with heavy walls. Sclerenchyma of whatever kind is, in fact, usually to be found in the foliar organs and occasionally in abundance. In Triodia irritans, for example, it constitutes a very large proportion of the tissue of the leaf, but it is a marked feature in the leaves of Hakea multilineata and $H$. leucoptera, as well as in the phyllodia of Acacia linophylla and other species of the genus. The pronounced development of cell-walls is a direct effect of drying conditions, as shown elsewhere.

In connection with the subject of the formation of heavy cell-walls and of mechanical tissue, it is pertinent to remark here that the writer was struck with the scarcity of the quality of spininess in such perennials as he saw in the drier portions of South Australia. Aside from the "needle bush," Hakea leucoptera, the "myall," Acacia rigens, and the "dead finish" A. tetragonophylla, whose leaves or phyllodia are spinose, and $A$. continua with spinescent branches, the writer does not recall having seen any perennials with very prominent spines. Other acacias with spinose phyllodia or branches, or with small spines, morphologically stipules, may be met with, but nowhere in the drier portions of South Australia is there to be found anything like the large development of spines as a characteristic of the perennial plants that one encounters, for example, in southern Arizona.

The chlorenchyma of the foliar organs is usually composed of palisade cells. This however, is not without its exceptions; for example, in Eremophila rotundifolia the chlorenchyma is of short cells. In this species the leaves are heavily covered with trichomes. There thus appears to be some relation between the presence of the one and the development of the other. In other species, however, as in Eremophila longifolia, there are both palisades and trichomes, and a similar condition is to be found in Acacia linophylla, not to mention others.

Reactions to the Subterranean Environment.

Relatively little is known concerning the direct reaction of the plants of the drier portions of South Australia to the soil and soil conditions, yet the subject is recognized as of much importance. Thus the presence of halophytes, which constitute an important part of the flora of the far north, is directly related to an excess of salts in the soil solution. This feature has been brought about in some way by the development on the part of the plants of the quality of tolerance to a highly concentrated soil solution. In this development an important element is the formation of plant juices of high concentration and therefore of high osmotic values.

The reaction of plants to the physical nature of the soil per se is probably also of importance. In coarse soils (as in sand) quick and fairly deep penetration of the rains and the formation of a dust 
mulch by which the water absorbed is well retained are prominent features in the water relations. Their relatively high temperatures and the quality of good aeration are also to be considered. In the vicinity of Oodnadatta, especially, where the observations were mostly made, it was found that the roots of species growing on the dunes had a fairly superficial type of root-system and that the roots extended far from the base of the stem. Whether, however, the same species growing under other soil conditions developed another type of rootsystem was not learned.

The foliage of species growing on the sand dunes exhibits characteristics of pronounced xerophytes, which may have been in part attributable to the brilliancy of the light, increased by reflection from the surface, and not wholly to the small water-supply. The soils in other regions, for example at Copley, are in part of a very fine texture, but whether the flora to be found on such soils is confined to them or is modified in any determinable way by them, was not learned. However, from the observations of Osborn (1914:114) more especially, which were made in the Mount Lofty Ranges near Adelaide, it might be expected that, in the drier portions of the state also, soils of unlike texture would support dissimilar floras. The entire question regarding the relation of plants to the physical nature of the soil, it may be said, is so closely connected with the temperature, moisture, and aeration of the soil, all of which are directly influenced by its texture, that to separate the special effects of the physical nature merely from the balance would be a difficult matter.

The amount of moisture in the soil plays a very important, not to say a leading, rôle among the environmental factors of the plants of the dry portions of the state. Although this is well known and generally recognized, particular reference to certain plant reactions to soil moisture may not be out of place. The limit of root penetration may coincide with the depth of the penetration of the rains, or of water derived from the rains, as in very dry regions. For this reason, in regions where the general penetration of the rains is slight, the placing of the roots of perennials is necessarily superficial. In this connection it is of interest to note the belief among the wheat-growers of the central portion of the state, as communicated by one of them, that wheat soil when thoroughly moistened to a depth of one meter contains sufficient water to mature the crop.

In certain species, especially in Kochia sp., filamentous rootlets are to be found on the main laterals which arise very soon after the soil has been moistened by the rains and which cease to function when the ground is dry. These occur in groups and serve the purpose of quickly and very considerably increasing the absorption surface of the roots. They are, in fact, "deciduous" roots and are analogous to such roots as are found in many perennials of southern Arizona. 


\section{BIBLIOGRAPHY.}

Alway, F. J., G. R. McDole, and R. S. Trumbell. 1919. Relation of minimum moisture-content of subsoil of prairies to hygroscopic coefficient. Bot. Gaz., vol. 67.

BLAck, J. M. 1917. Additions to the flora of South Australia. No. 12, Trans. Roy. Soc. South Australia.

- 1919. Additions to the flora of South Australia. No. 15, Trans. Roy. Soc. South Australia.

Briggs, L. J., and H. L. Shantz. 1911. A wax-seal method for determining the lower limit of available soil moisture. Bot. Gaz., vol. 51.

- 1912. The wilting coefficient and its indirect determination. Bot. Gaz., vol. 53.

Cannon, W. A. 1911. The root-habits of desert plants. Carnegie Inst. Wash. Pub. No. 131.

. 1913. Botanical features of the Algerian Sahara. Carnegie Inst. Wash. Pub. No. 178.

Book No. 13.

- 1915. Root-growth of Opuntia versicolor at constant soil temperatures. Carnegie Inst. Wash. Year Book No. 14.

. $1915^{2}$. Distribution of the cacti with reference to the rôle played by the relation of root response to temperature. Carnegie Inst. Wash. Year Book No. 14.

- $1915^{3}$. On the relation of root-growth and development to the temperature and aeration of the soil. Amer. Jour. Bot., vol. 2.

. 1916. Rate of root-growth of Covillea tridentata (in relation to the temperature of the soil). Carnegie Inst. Wash. Year Book No. 15.

- $1916^{2}$. Distribution of the cacti with especial reference to the rôle played by the root response to soil temperature and soil moisture. Amer. Nat., vol. 50.

- 1917. Relation of the rate of root-growth in seedlings of Prosopis velutina to the temperature of the soil. Carnegie Inst. Wash. Year Book No. 16.

- 1918. Root-growth in desert plants and the oxygen-supply of the soil. Carnegie Inst. Wash. Year Book No. 17.

- and E. E. Free. 1917. The ecological significance of soil aeration. Science, n. s., vol. 45 .

Carnegie, D. W. 1898. Spinifex and sand. A narrative of five years' pioneering and exploration in Western Australia.

Collins, M. J. 1918. On the leaf-anatomy of Scavola crassifolia, with special reference to the epidermal secretion. Proc. Linn. Soc. New South Wales.

Coville, F. V., and D. T. MacDougal. 1903. Desert Botanical Laboratory of the Carnegie Institution. Carnegie Inst. Wash. Pub. No. 6.

Fitring, H. 1911. Die Wasserversorgung und die osmotischen Druchverhältnisse der Wüstenpflanzen.. Zeit. Bot., vol. 3 .

Free, E. E., and B. E. Livingston. 1915. The relation of soil aeration to plant growth. Carnegie Inst. Wash. Year Book No. 14.

Foller, G. D. 1918. Raunkiaer's "leaf forms," "leaf-size classes," and statistical methods. Plant World, vol. 21, p. 30.

Gregory, J. W. 1906. The dead heart of Australia. A journey around Lake Eyre in the summer of 1901-1902, with some account of the Lake Eyre basin and the flowing wells of central Australia.

- 1916. Australia.

HaNN, J. 1903. Handbook of climatology. Eng. trans.

HARRIS, A. J. 1915 . The osmotic pressure of vegetable saps in relation to local environmental conditions in the Arizona deserts. Carnegie Inst. Wash. Year Book No. 14.

- J. V. LAwrence, and R. A. Gortner. 1916. The cryoscopic constants of expressed vegetable saps, as related to local environmental conditions in Arizona deserts. Physiol. Res., vol. 2.

HIlgard, E. W. 1906. Soils: their formation, properties, composition, and relations to climate and plant-growth in humid and arid regions.

How ARd, A., and R. S. Hole. 1918. Recent investigations on soil-aeration. Indian Forest Records.

$\longrightarrow$, and G. L. C. Howard. 1915. Soil ventilation. Agr. Res. Inst. (Pusa) Bull. 52. 
Howchin, Walter, and J. W. Gregory. 1909. The geography of South Australia.

Hont, HI. A. 1912. Annual summary. Commonwealth Bur. Meteorology, vol. 3, No. 13.

1914. The climate and meteorology of Australia. Commonwealth Bur. Meteorology Bull. No. 9.

- 1916. The climate and meteorology of Australia. Commonwealth Bur. Meteorology Bull. No. 1 (revised ed.).

JACK, R. LockHART. 1915. The geology and prospects of the region to the south of the Musgrave Ranges, and the geology of the western portion of the Great Australian artesian basin. Geol. Surv. South Australia Bull. No. 5.

Jutson, J. T. 1914. An outline of the physiographical geology (physiography) of Western Australia. Geol. Surv. Western Australia Bull. No. 61.

Livingston, B. E. 1906. The relation of desert plants to soil moisture and evaporation. Carnegie Inst. Wash. Pub. No. 50.

MAcDougal, D. T. 1918. Temperature and the hydration and growth of colloids and of cell-masses. Carnegie Inst. Wash. Year Book No. 17.

. 1918. The nature and course of growth in higher plants. Carnegie Inst. Wash. Year Book No. 17.

, and collaborators. 1914. The Salton Sea: A study of the geography, the geology, the floristics, and the ecology of a desert basin. Carnegie Inst. Wash. Pub. No. 193. , E. R. LoNG, and J. G. Brown. 1915. End results of desiccation and respiration in succulent plants. Physiol. Res., vol. 1. , and H. A. Spoenr. 1918. The origination of xerophytism. Plant World, vol. 21. , - - 19182. The origin and physical basis of succulence in plants. Carnegie Inst. Wash. Year Book No. 17.

MAIDEN, J. H. 1904. A critical revision of the genus Eucalyptus. Vol. 1.

Musson, C. T. 1904. Variations in rainfall at H. A. College, Richmond, New South Wales. Misc. Pub. No, 782, Agr. Gaz. of N. S. Wales.

Osborne, T. G. B. 1914. Notes on the flora around Adelaide. New Phyt., vol. 13.

Palladin, V. I. 1917. Plant physiology. Eng. trans.

Paulsen, O. 1912. Studies on the vegetation of the Transcaspian lowlands. Second Danish Pamir Expedition.

Pitrman, E. F. 1914. The great Australian artesian basin and the source of its water. Geol. Surv. New South Wales.

Richards, H. M. 1918. Acidity of mesophytic and succulent forms of Castilleia, Ericameria, and Erigeron. Carnegie Inst. Wash. Year Book No. 17.

Schimper, A. F. W. 1903 . Plant-geography upon a physiological basis.

Shreve, E. B. 1915. The autonomic movements and water-relations of the cacti. Carnegie Inst. Wash. Year Book No. 14.

Shreve, F. 1914. Rainfall as a determinant of soil moisture. Plant World, vol. 17.

1915. The vegetation of a desert mountain range as conditioned by climatic factors. Carnegie Inst. Wash. Pub. No. 217.

SolmReder, H. 1899. Systematische Anatomie der Dicotyledonen.

Spencer, Baldwin, and F. J. Gillen. 1912. Across Australia.

Spoenr, H. A. 1917. The carbohydrate economy of cacti. Carnegie Inst. Wash. Year Book No. 16.

- - 1918. The carbohydrate economy of cacti. Carnegie Inst. Wash. Year Book No. 17.

TAyLor, G. 1914. The physical and general geography of Australia. Federal Handbook of Australia, B. A. A. S.

- 1918. The Australian environment. Commonwealth of Australia, Advisory Council of Science and Industry.

- 19182. The climatic factors influencing settlement in Australia. Year Book Commonwealth of Australia No. 11.

WARMING, E. 1909. CEcology of plants.

White, S. A. 1915. Scientific notes on an exploring expedition into the northern regions of South Australia. Trans. Roy. Soc. So. Australia, col. 39. 1915. 


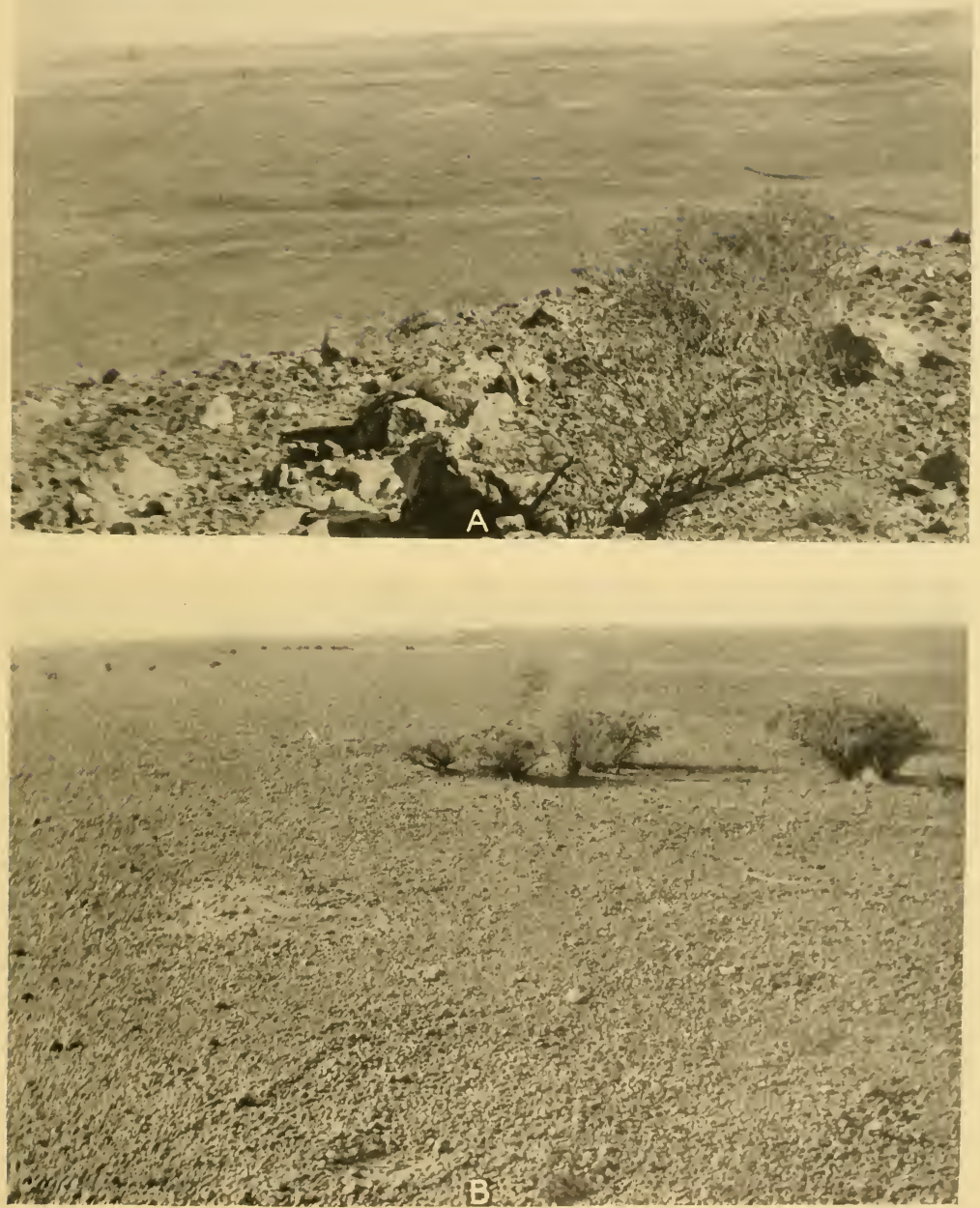

A. View looking north from O'Halloran's Mount, Codnadatt: showing lower plain, with upper plain at extreme right in background.

B. Lower plain near Codnardatta, showing "gihbers" on the surfare and typieal depression, with species of Eremophila. 


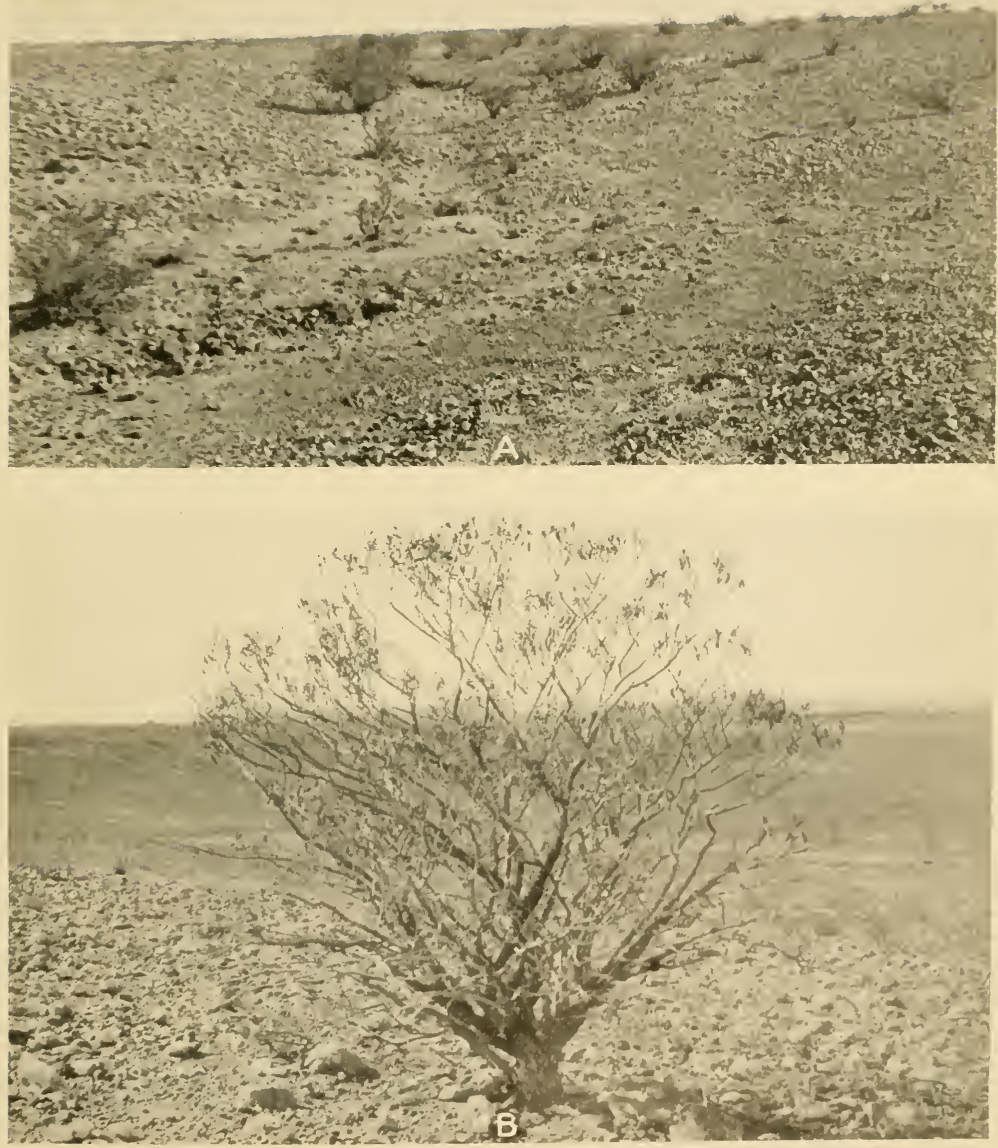

A. Eremophila freelingii in a shallow wash on slope of upper plain near Oorlnadatta.

B. Eremophila freelingii in a shallow wash on the edge of upper plain west of Neales River, Oodnadatta. 


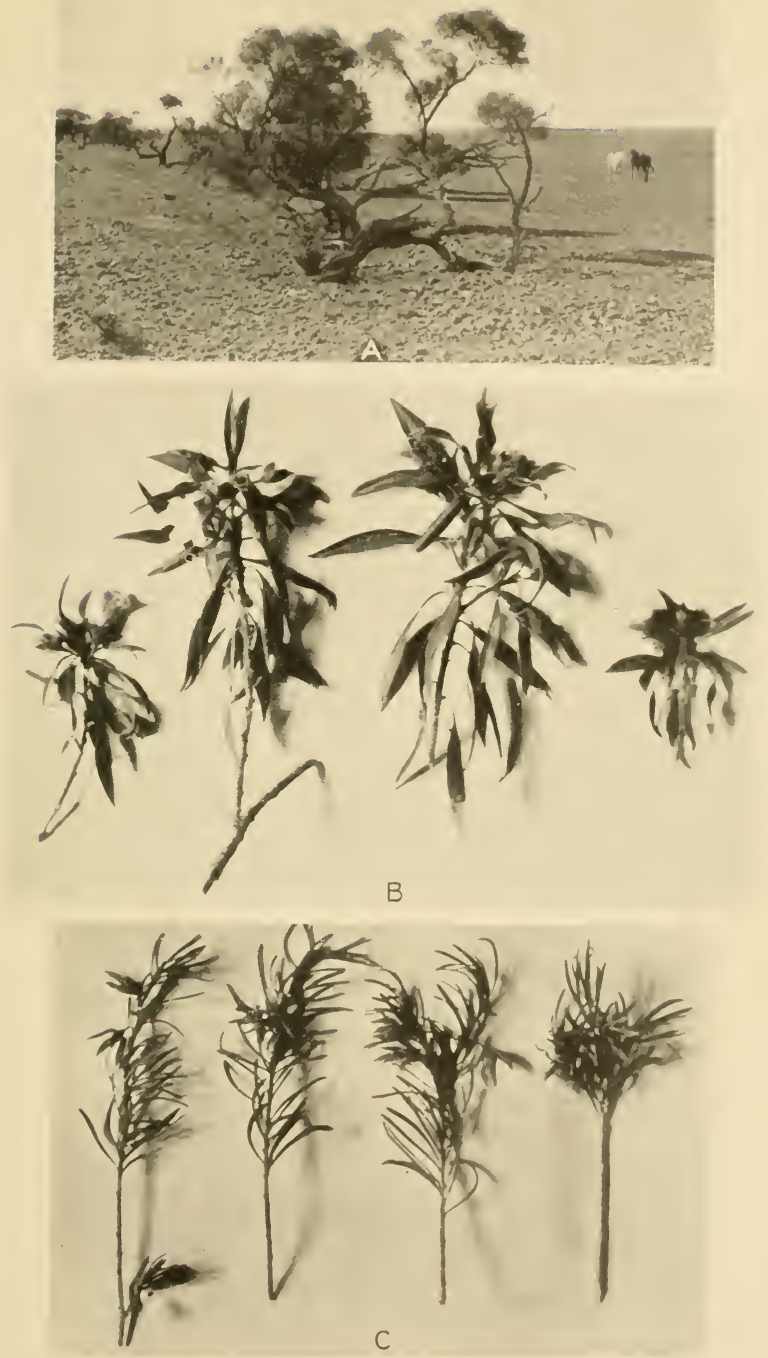

A. Acacia cambadgei in a shallow wash on the slope connerting upper and lower plains west of Neales River, Oodnalutta.

B. Shoot-tins with leaves, Eremophila freelingii, from upper plain west of Neales River, Oodnadatta.

C. Sheot-tips with leaves, Eremophila latrobei, from ia wash connecting upper and lower plains nrest of Neales River, Oodnadata. 


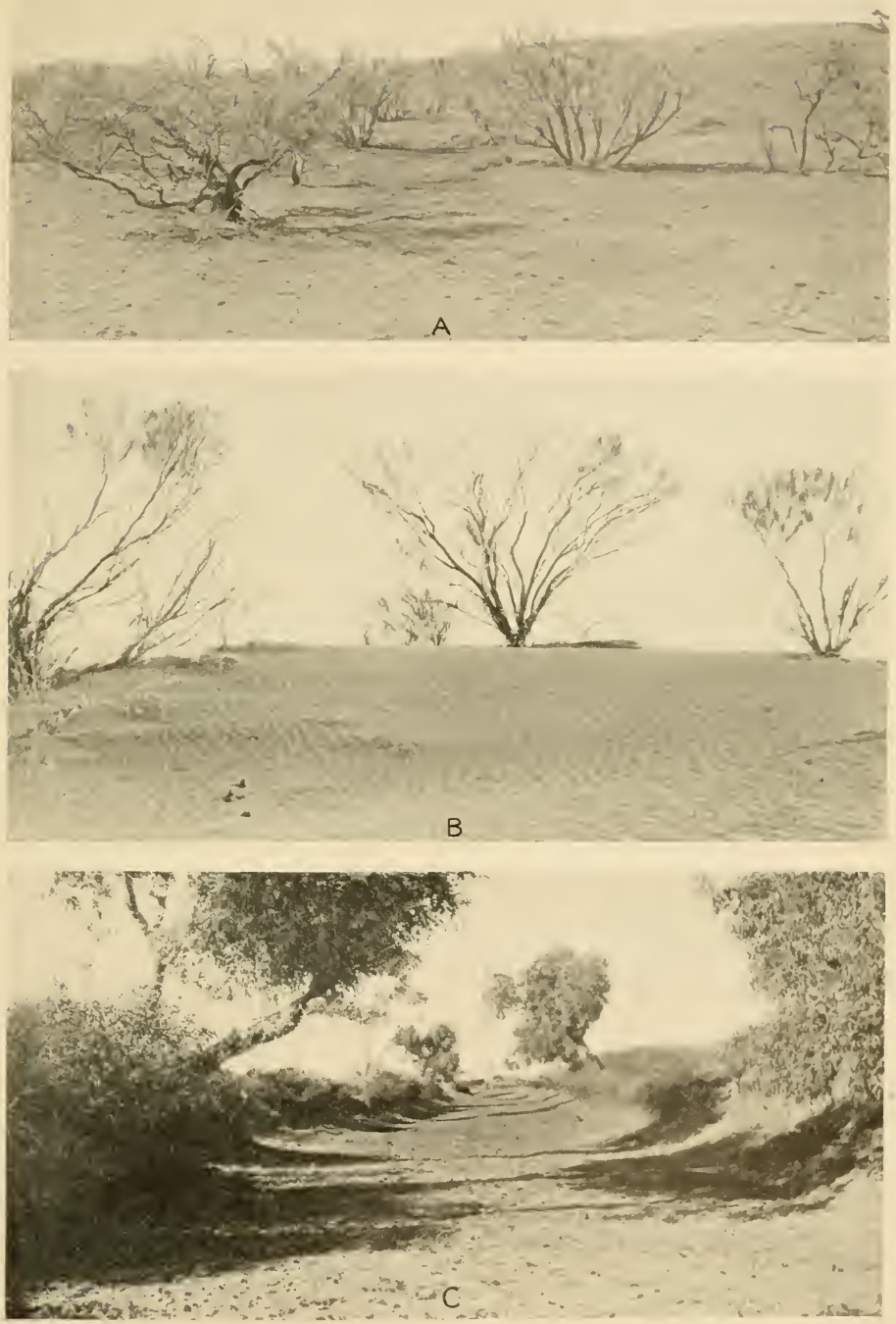

A. Acacia tetragonophylla, near west base of sandhills east of Oodnadiatta.

B. Acacia linophylla on sandhills east of Oodnadatta.

C. Short channel, Neales River, with Eucalyptus rostrata and Acacia stenophylla, small shrubs, on the banks, Oodnadatta. 

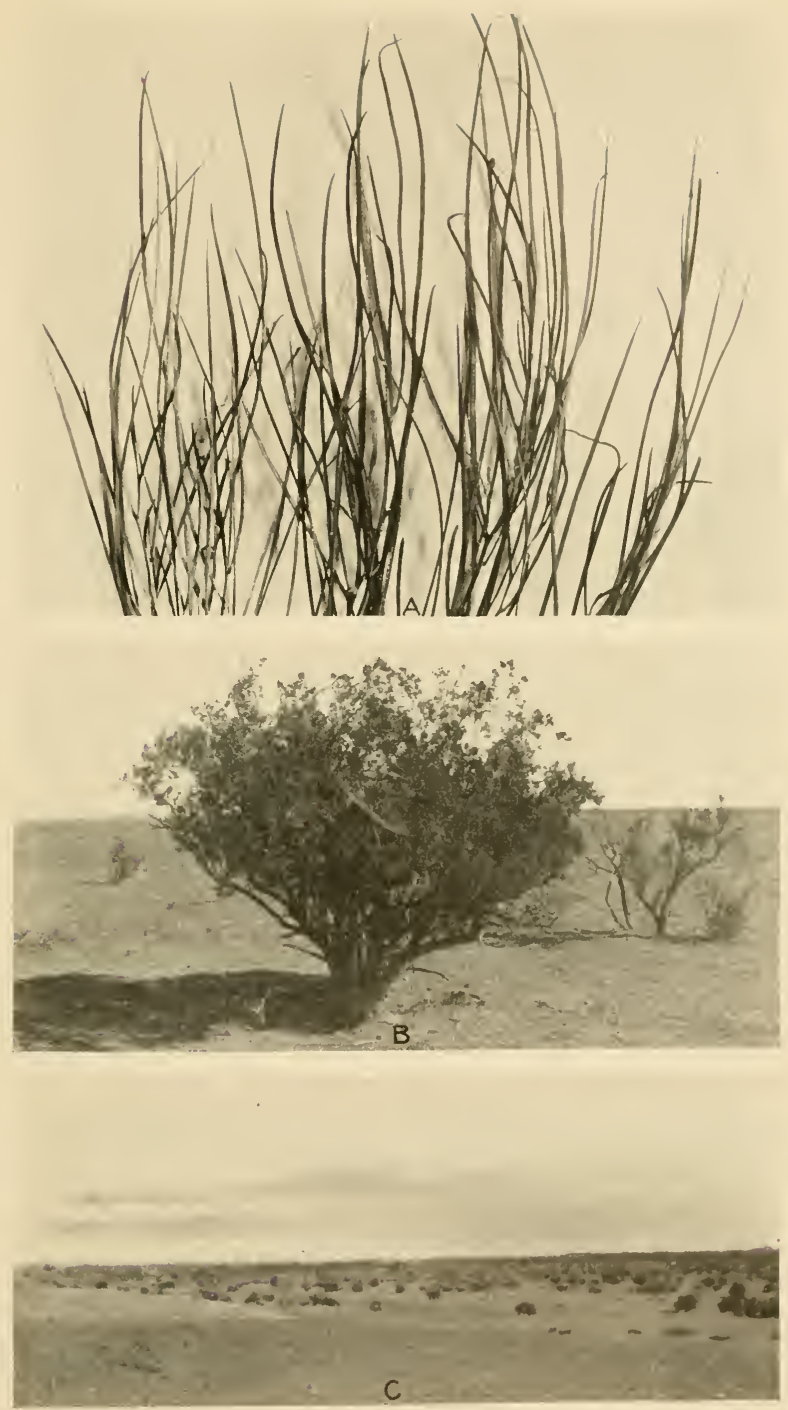

A. Phyllodia of Acacia linophylla from sandhills near Oodnadatta. B. Eremophila neglecta near hase of sandhills east of Godnadatta. C. Neales River bottoms from the lower plain, Oodnadatta. 


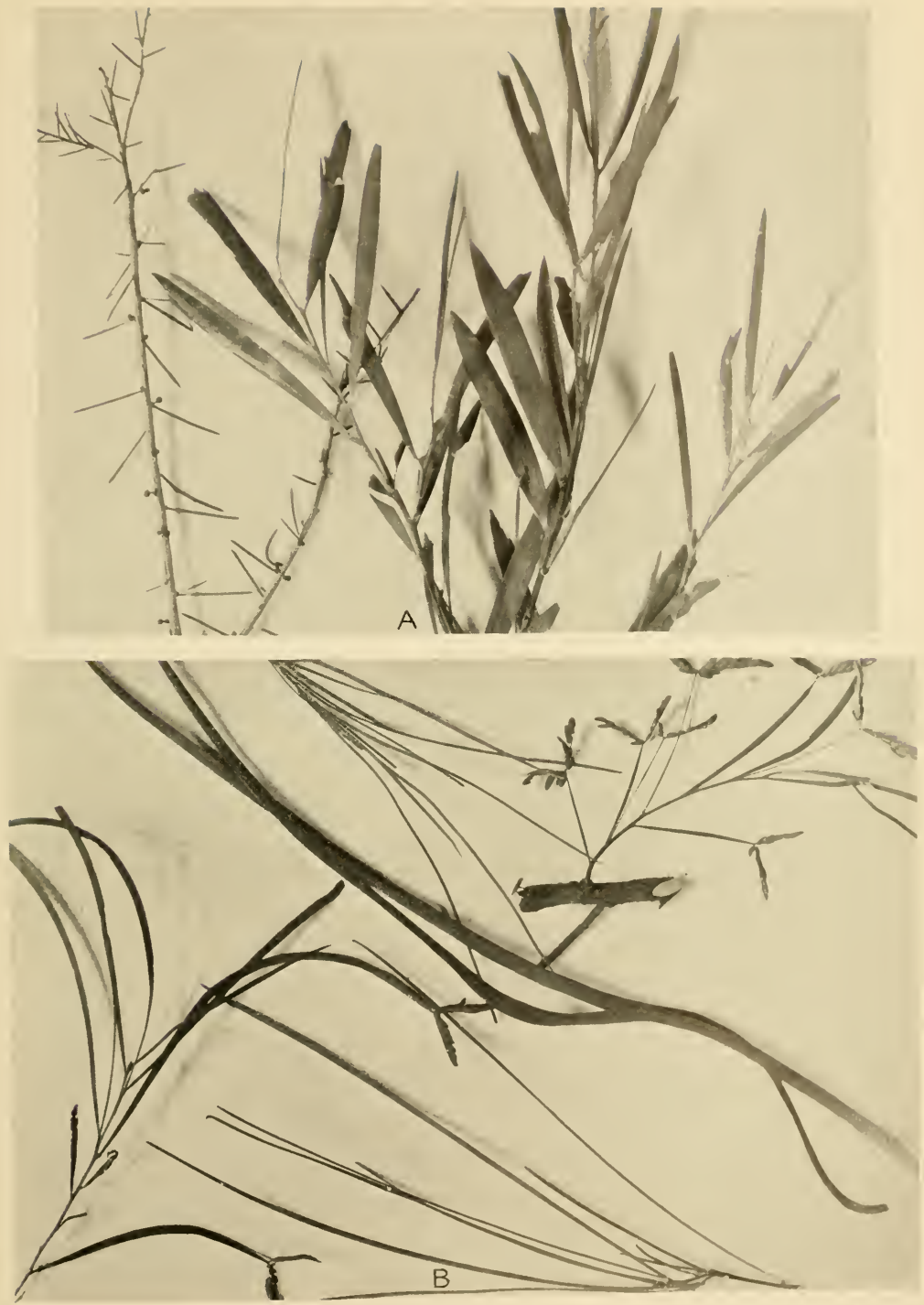

A. Shoot-tips and phyllodia of Acacia tetragonophylla, left, and A. cambadgei, right, from Neales River, Oodnadatta.

B. Leaves and phyllodia of Acacia stenophylla from Neales River, Oodnadatta. 


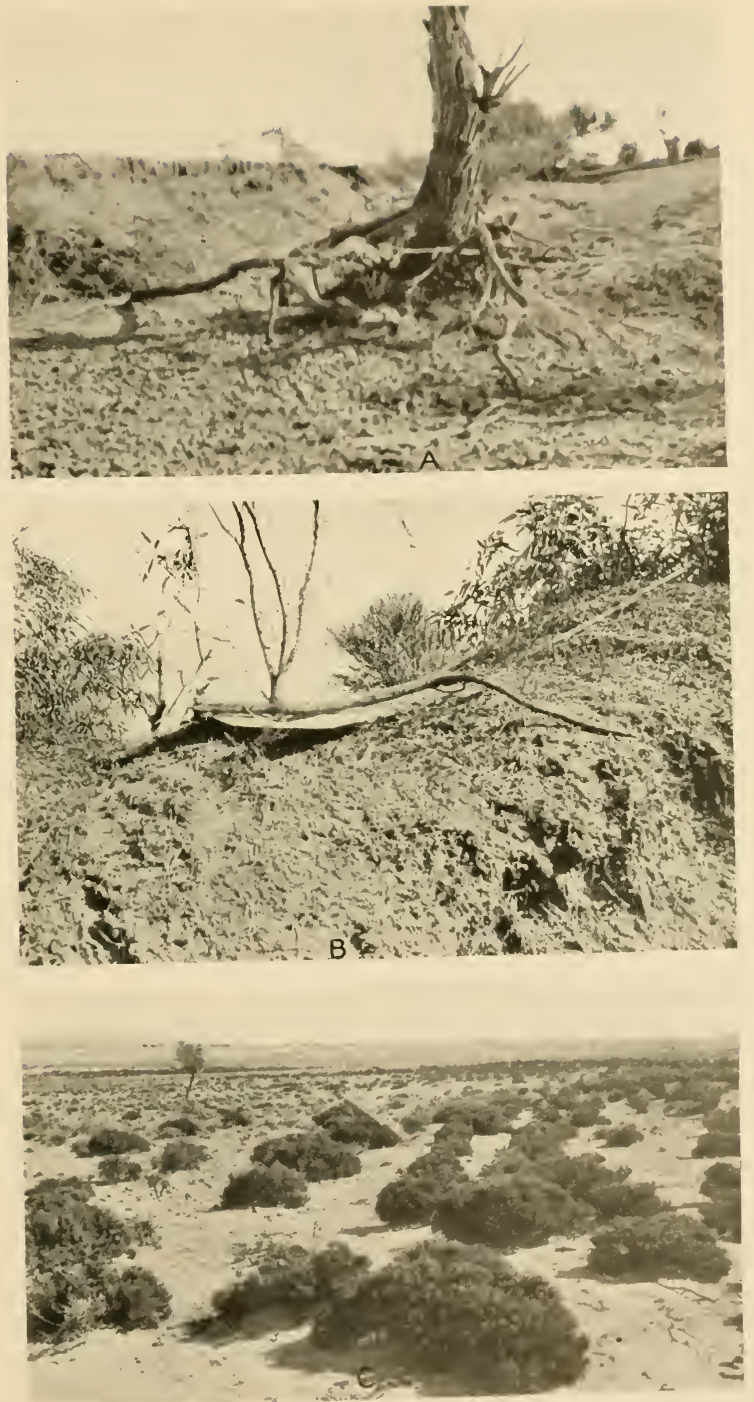

A. Prominent development of horizontal roots in Acacia cambadgei, Neales River, Oodnadatt:

B. Vegetative reproduction in Acacia stenophylla from floor-plain, Neales River, Oodnadatt:1.

C. Kochia sedifolia on low slope above Copley Plain on Yulnamutana road, Copley. 


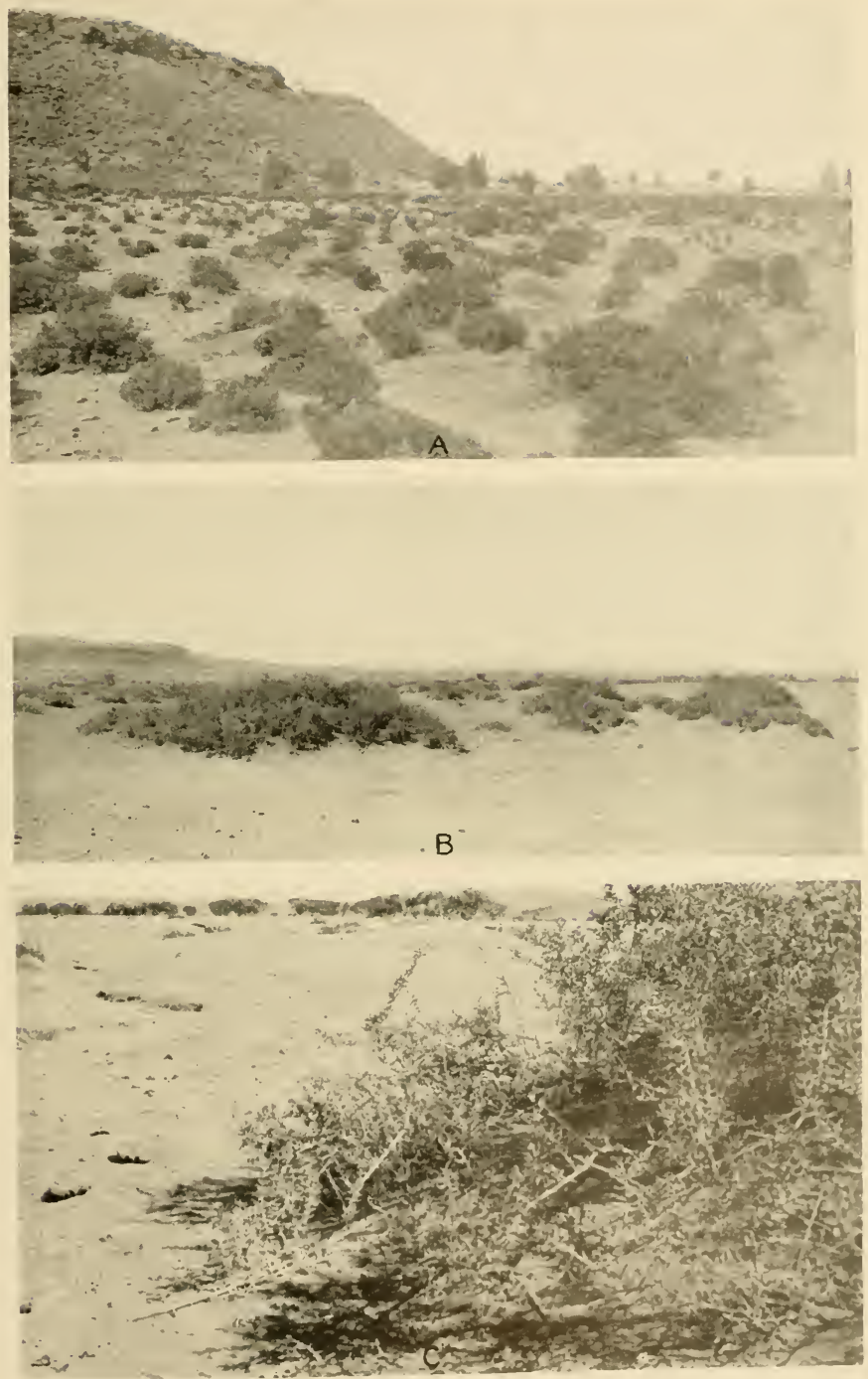

A. Zygophyllum fruticosum at edge of Copley Plain by Table Mountain. The trees in the background are Casuarina lepidophloia, Copley.
B. Nitraria schaberi hillock colonies on Copley Plain. Table Mountain is in the background at left.

C. Detail of edge of colony of Nitraria scheberi, showing horizontal prostrate branches by which the hillock colony is extended, Copley. 


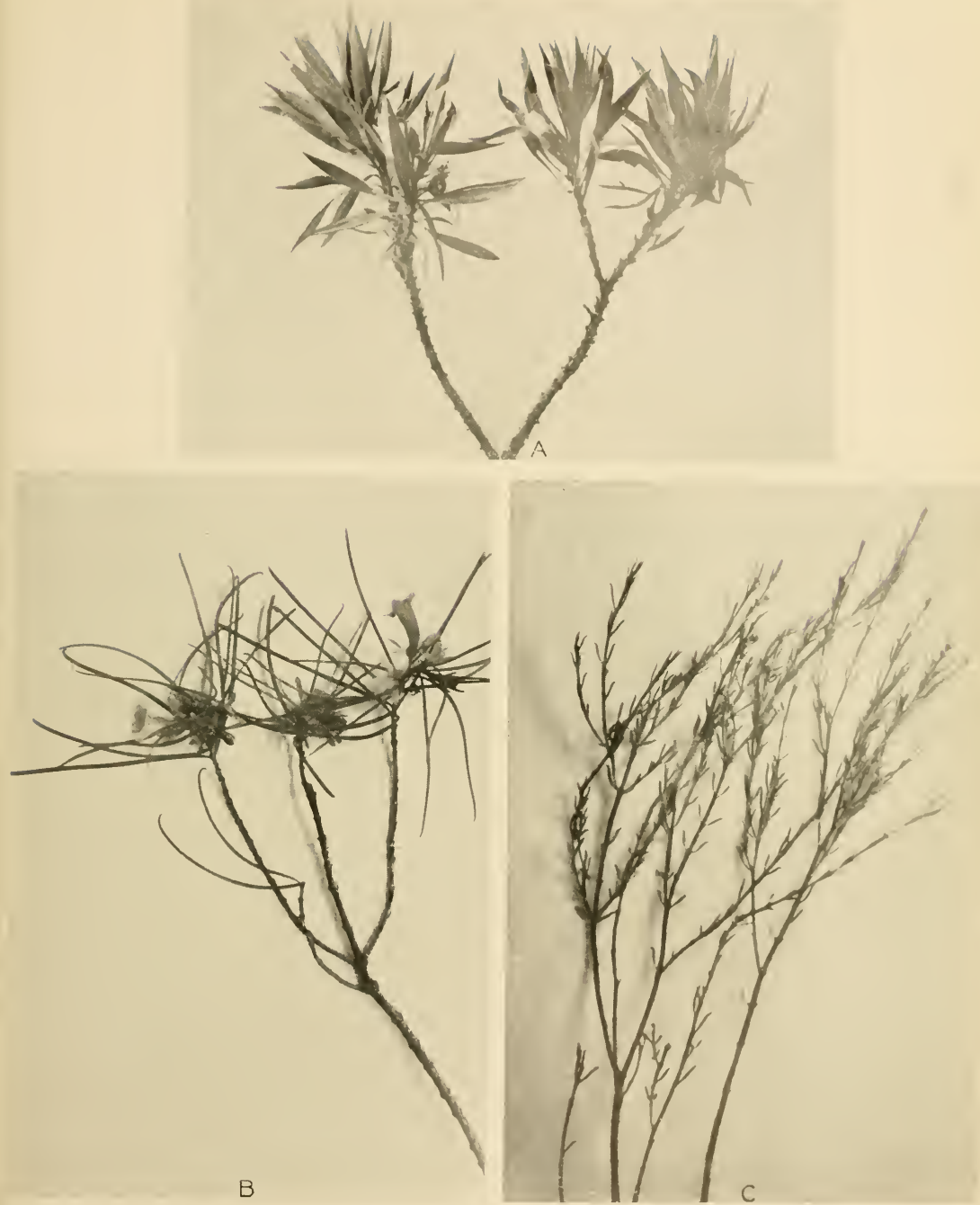

A. Shoot-tip of Eremophila freelingii from low hills on Mount Scrles roas, Copley.

B. Eremophila oppositifolia, showing leaves and flowers from rounded low hills on Mount Serles road, Copley.

C. Pholidia scoparia, "broom," from low hills on Mount Serles road east of Copley. 


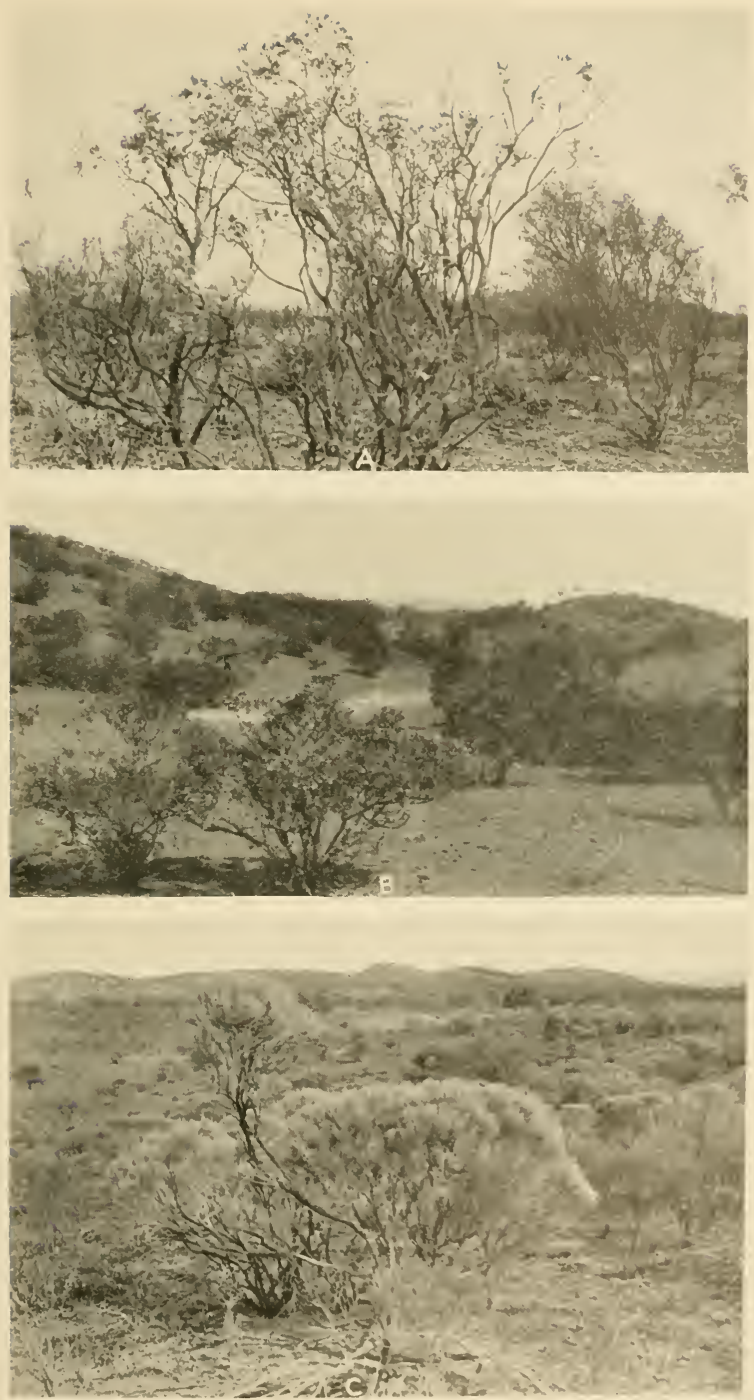

A. Cassia sturtii, constituting at mono-specific community on Mount serles road, Copley.

B. Nono-specific community of Eremophila frelingii in low hills along IIount serles road, Copley.

C. Mono-specific community of Pholidia scoparia in low hi!ls on Mount serles road, Copley. 


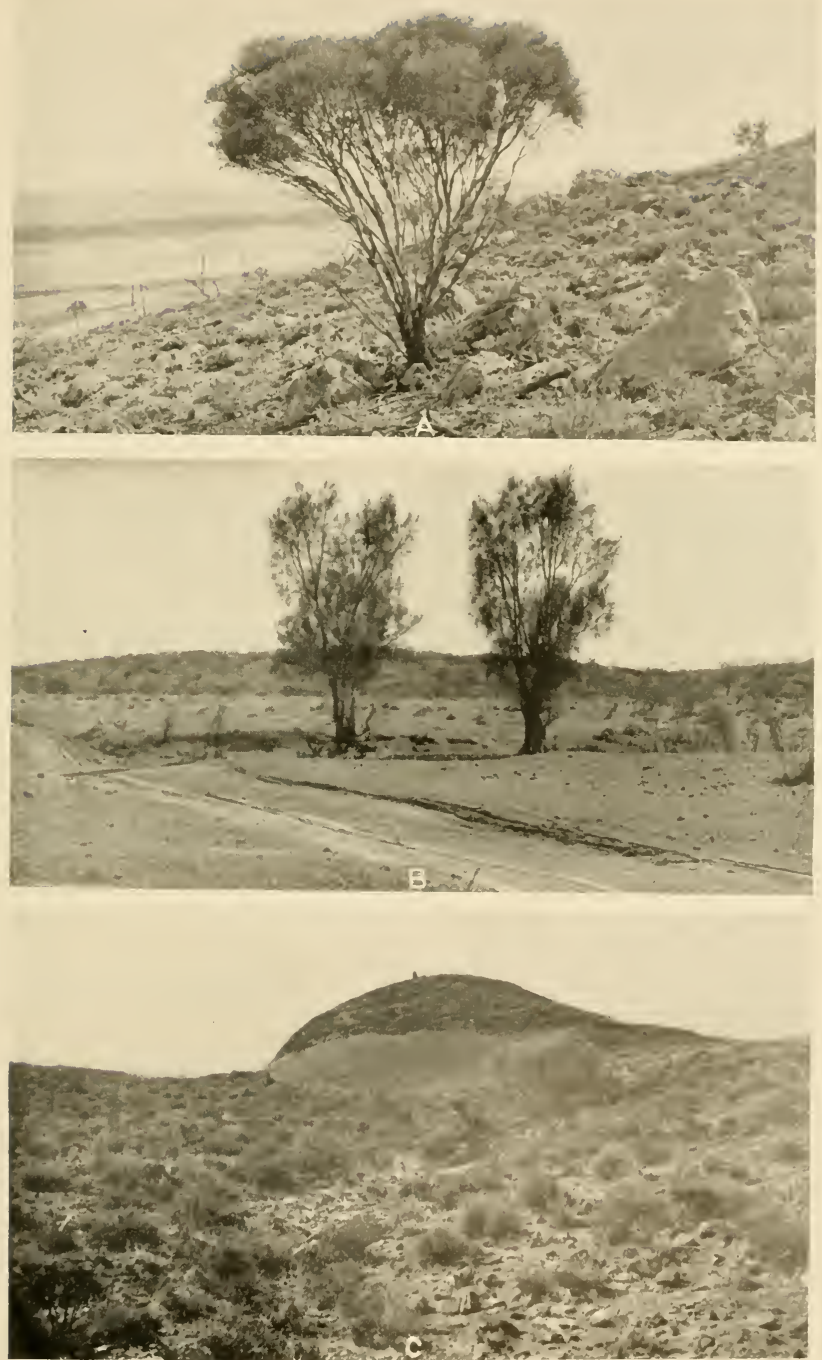

A. Hakea leucoptera on southern slope of Table Mountain, Copley.

B. Casuarina lepidophloia, or "oak," at south base of Table Mountain, Copley.

C. Community of Zygophyllum fruticosum near Mlount of Light, Copley. 


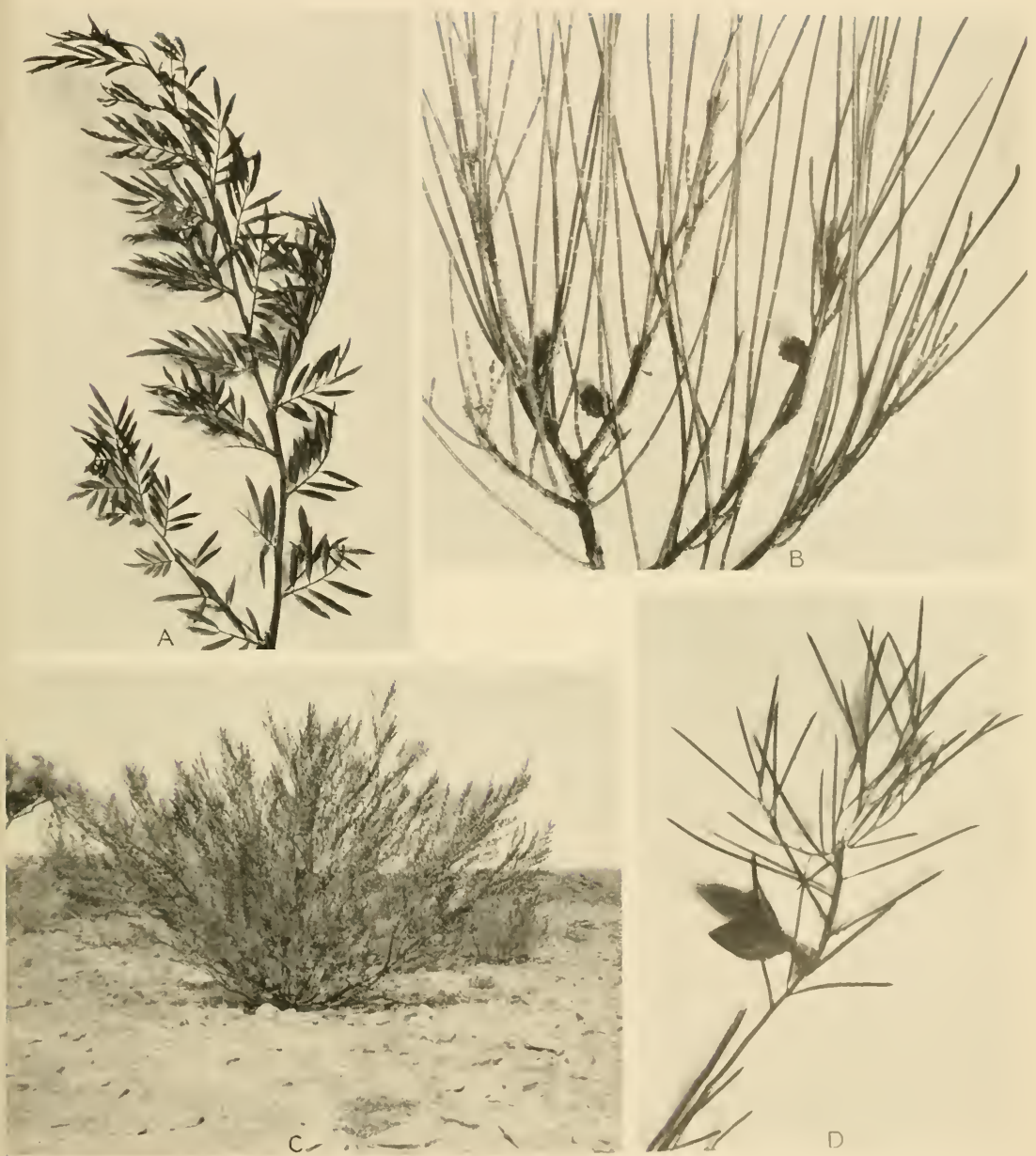

A. Petalostylis labicheoides from south base of Table Mountain. Copley.

B. Casuarina lepidophtoia, Copley.

C. Petalostylis labicheoides at south base of Table Monntain, Copley.

D. Shoot habit of Haliea leucoptera, with fruit, from Table Mountain, Conpley 


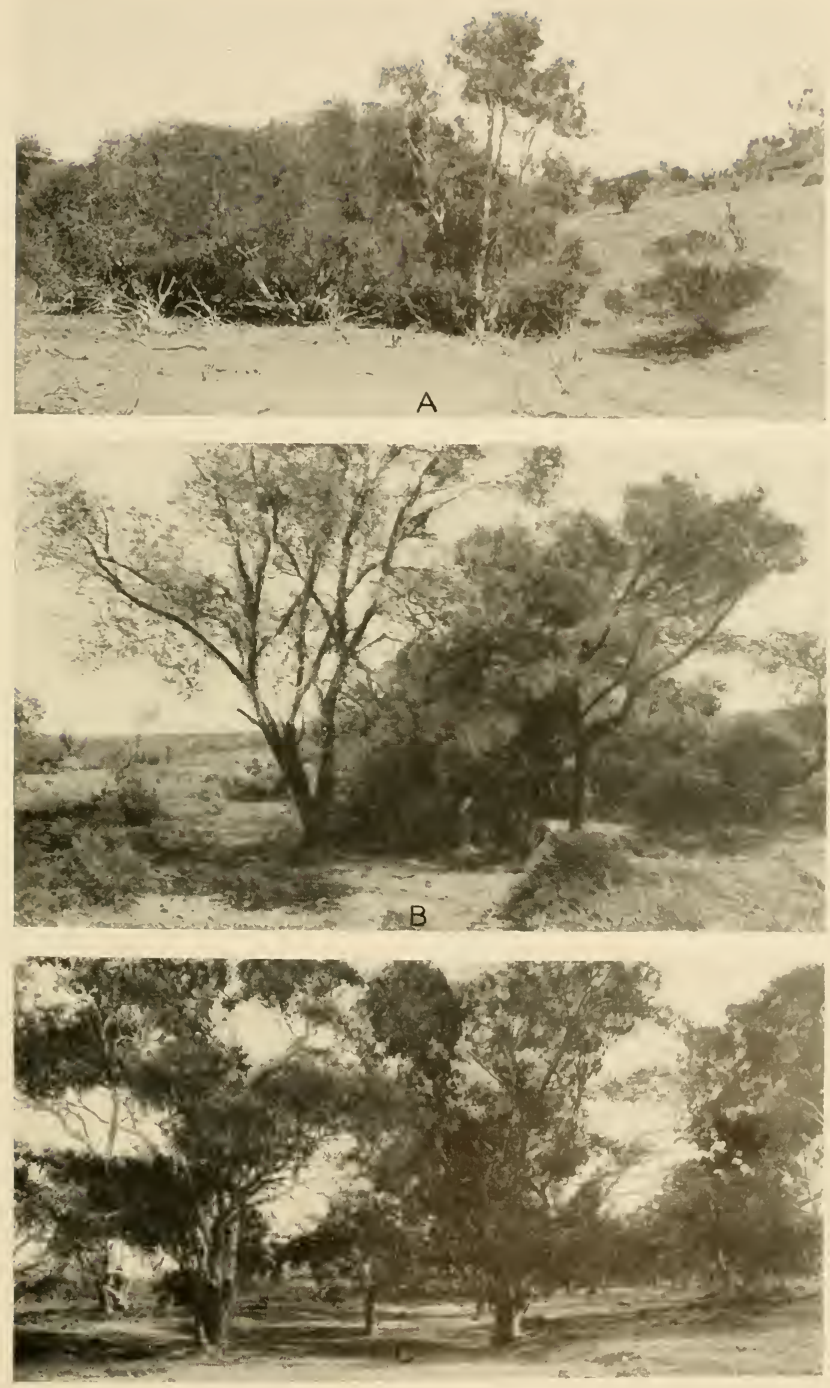

A. Melaleuca glomerata, the "white" tea-tree, on a small branch of Leigh's Creek, Mount Serles road, Copley.

B. Melaleuca parviflora, the "black" tea-tree, near Myrtle Springs road, Copley:

C. Eucalyptus rostrata, the red gum, on Leigh's Creek, Copley. 


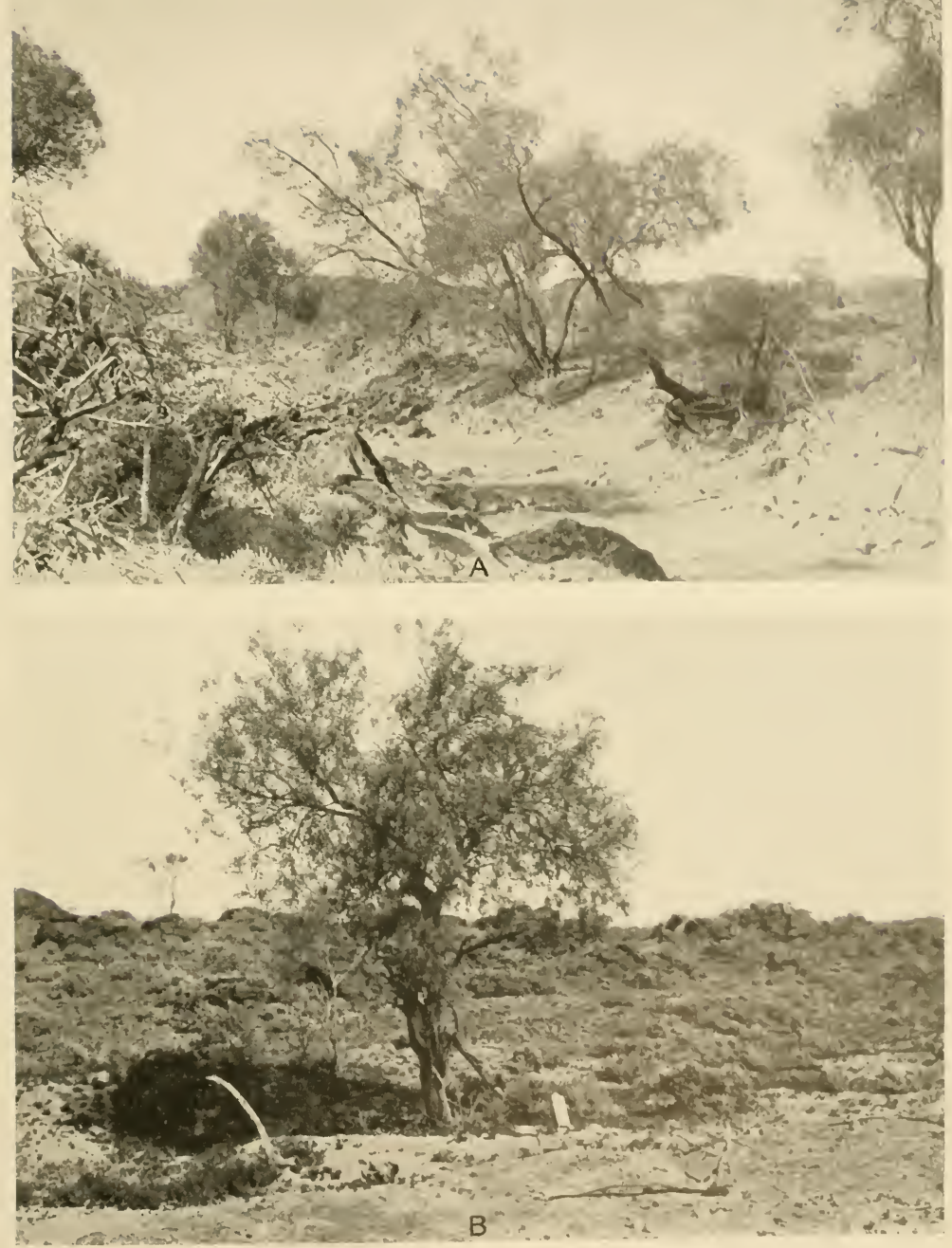

A. Eremophila alternifolia at side of small wash near. Ifount of Light. Copley.

B. Eremophila longifolia on edge of Copley Plain near Leigh's Creek, Copley. 


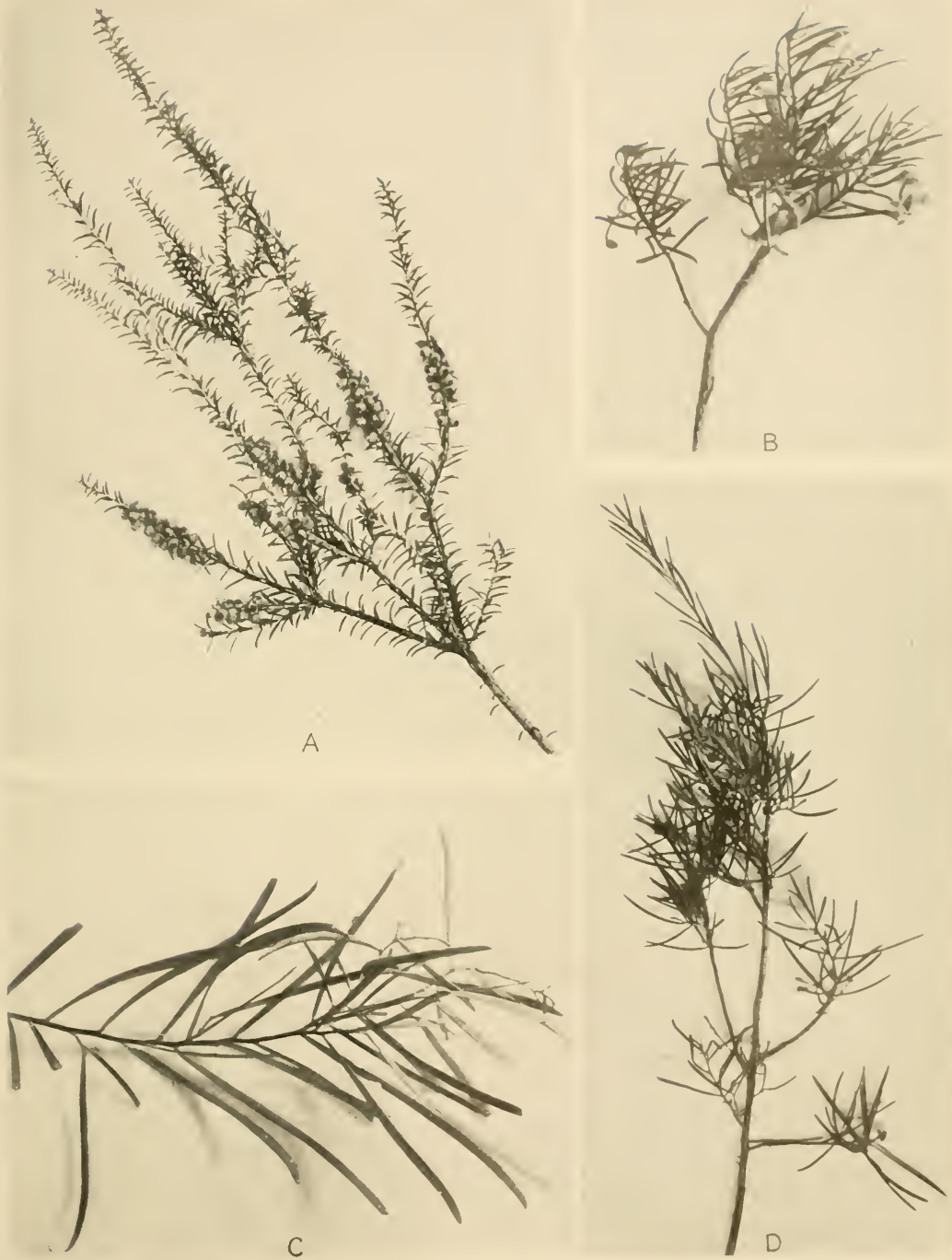

A. Shoot-tip showing leaves and fruits of Melaleuca parviflora, or "black" tea-tree, from Myrtle Springs road, Copley.

B. Tip of shoot of Eremophila alternifolia with Howers and leaves, Copley.

C. Leafy shoot of Acacia varians from a wash east of Copley.

D. Melaleuca glomerata, or "white" tea-tree, from Leigh's Creek, Copley. 


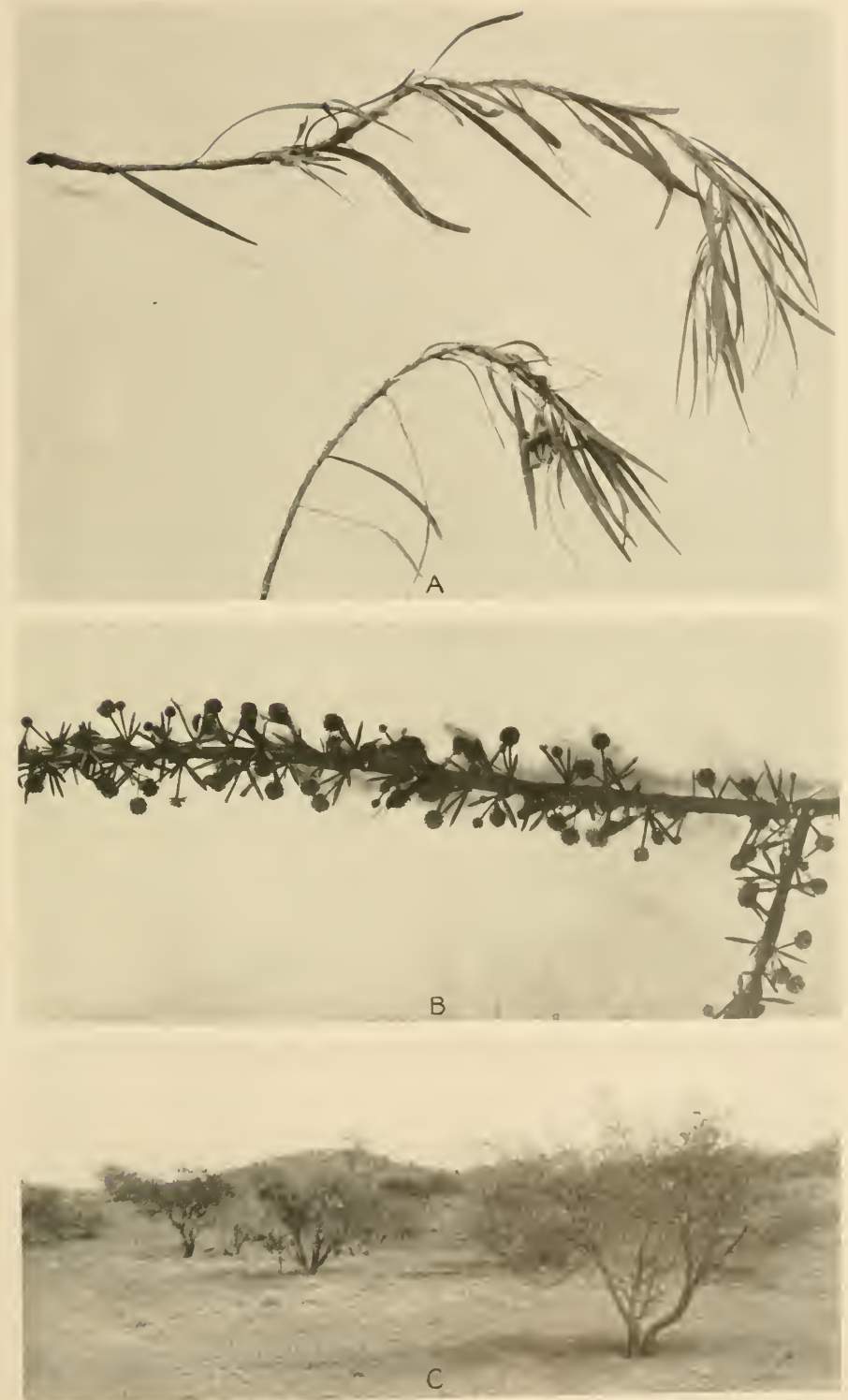

A. Eremophila longifolia, Copley.

B. Branch of Acacia tetragonophylla with short spinose phyllorlia and inforesenene: buds, Copley.

C. Acacia tetragonophy?la in low hills on Mount sarles road, east of Copley. 



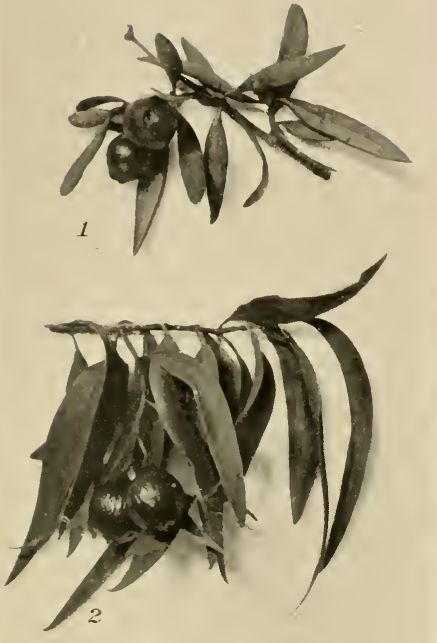

A

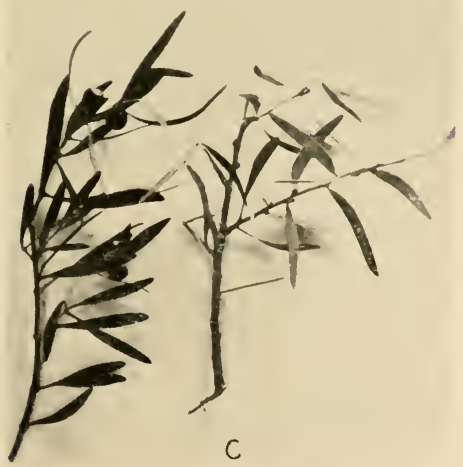

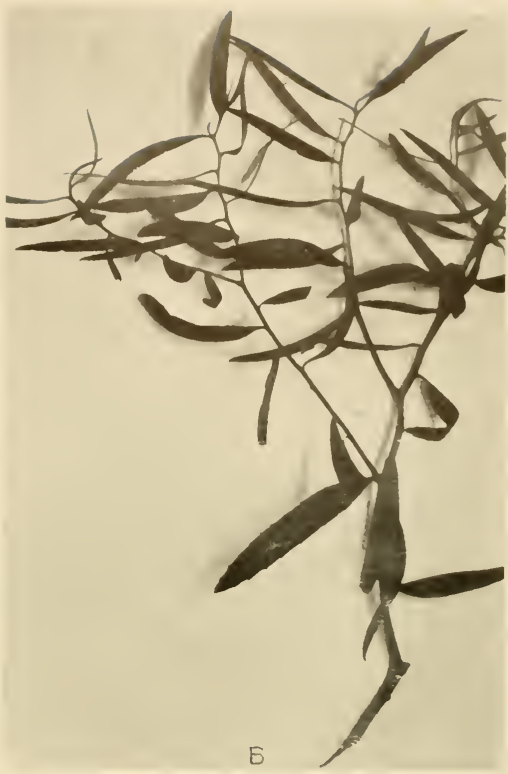

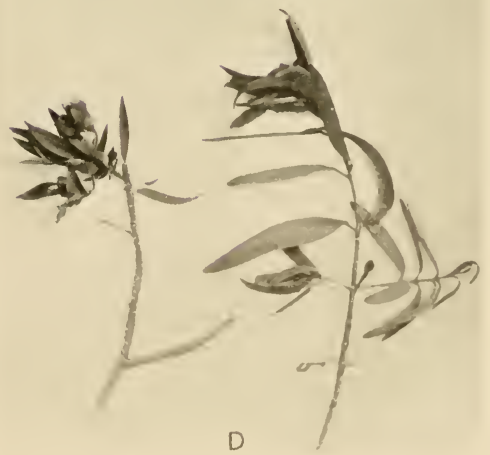

A. Leafy shoot-tips with fruit of Fusanus spicalus, the "quandang," and F. acuminatus, the native "peach," Mount Deception Range, Copley.

B. Myoporum platycarpum from low hills on Mount serles roarl, Copley.

C. Shoot-tip with leaves and fruit of Lorauthus exocurpi and leafy hranch of host, Acacia sentis, Cepley.

D. Loranthus exocarpi, at right, and Eremophila brounii, host, Copley: 


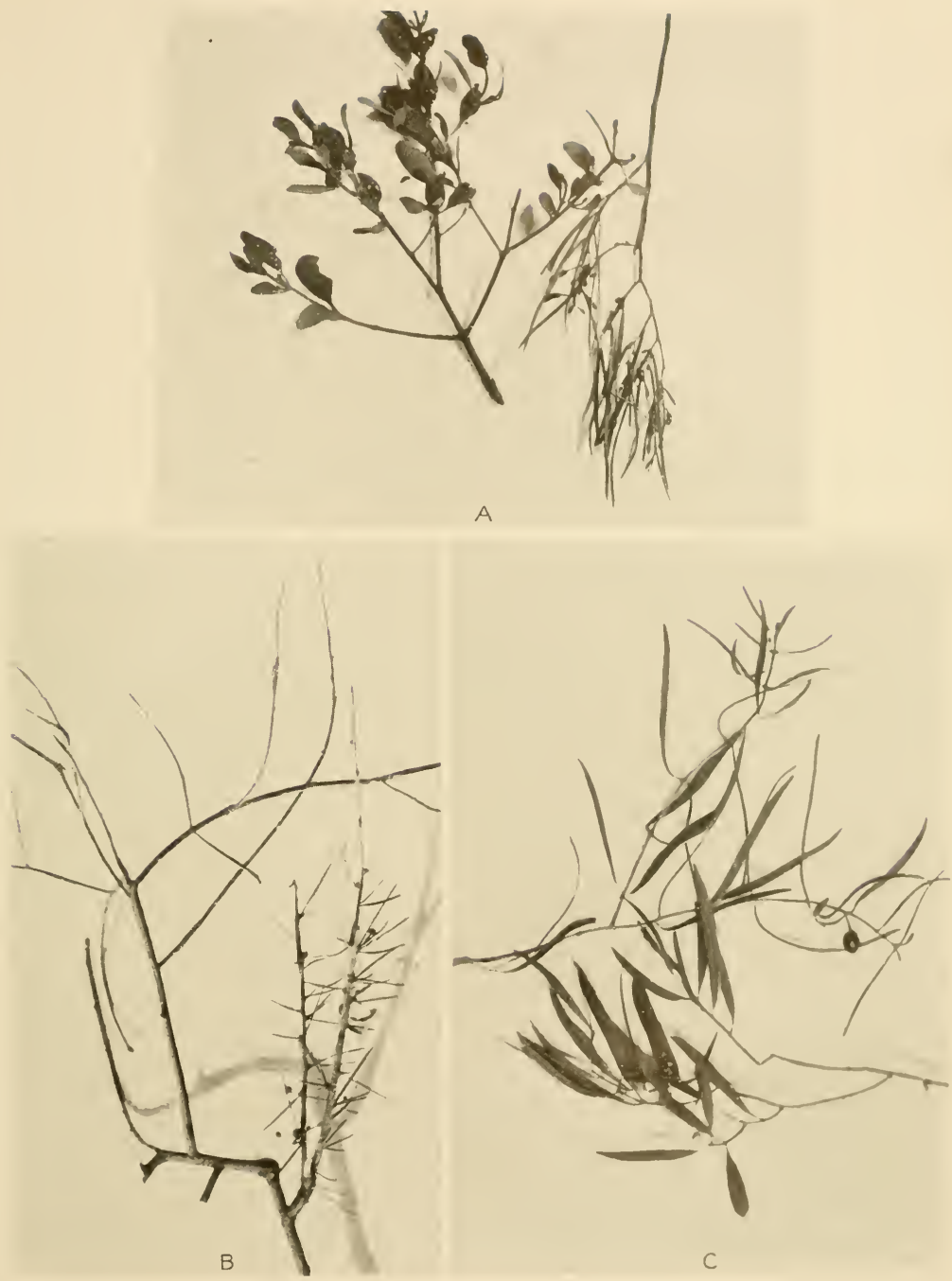

A. Loranthus quandang, with oval leaves, and the narrow-leaved form of Acacia aneura, the "mulga," its host. From Mount Serles road, east of Copley.

B. Loranthus linearifolius on Acacia tetrayonophylla. The host is shown with characteristie spine-like phyllodia. Copley.

C. Loranthus excarpi, with leaves and fruit and shoot-tip of its host, Myoporum platycarpum. Copley. 


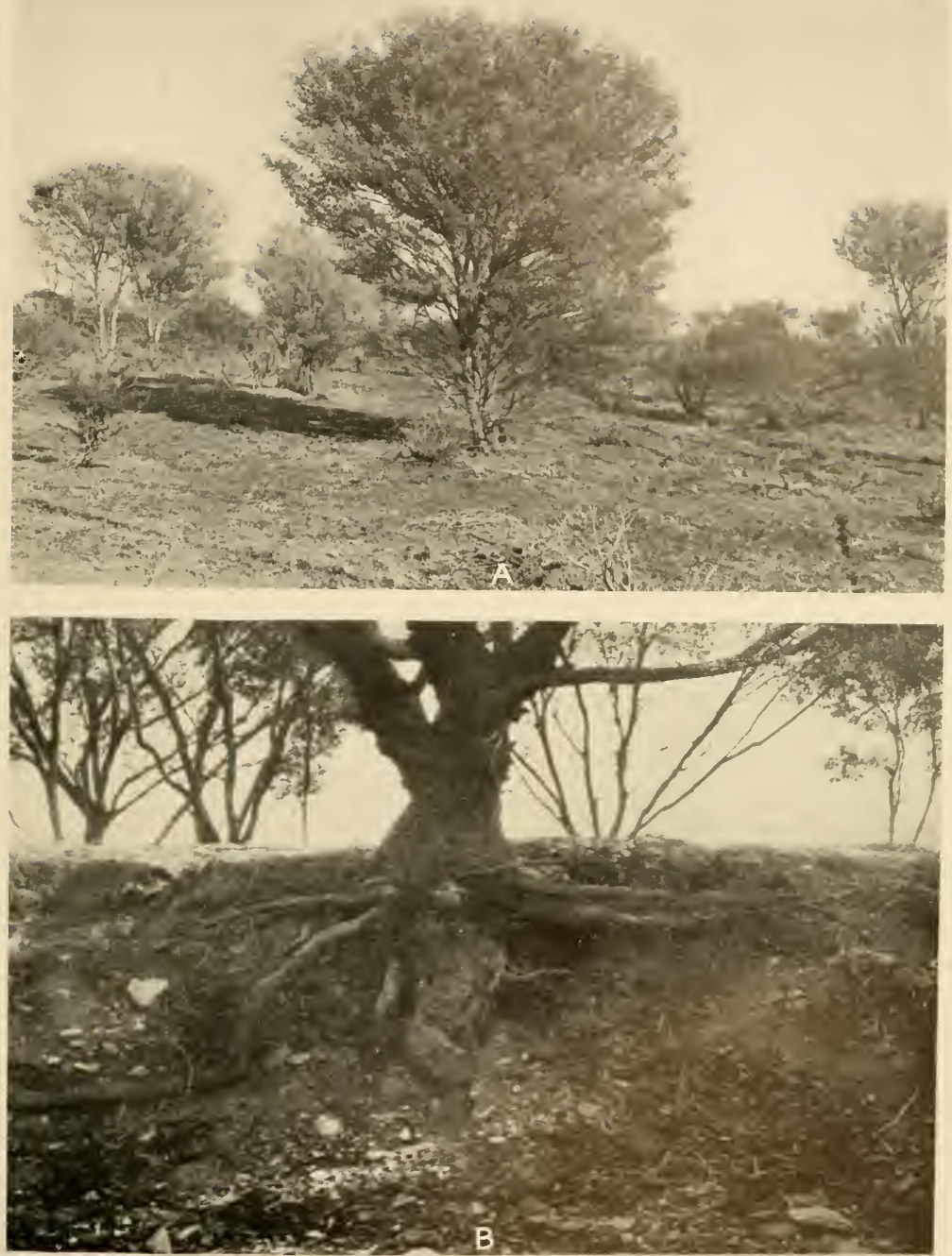

A. Acacia aneura, the mulga, at Ooldea.

B. Eucalyptus oleosa by a wash at the eastern base of Mount Deception Range. The prominent stem base and enlarged erown of the taproot, both characteristic of the "mallee," are shown. Copley. 


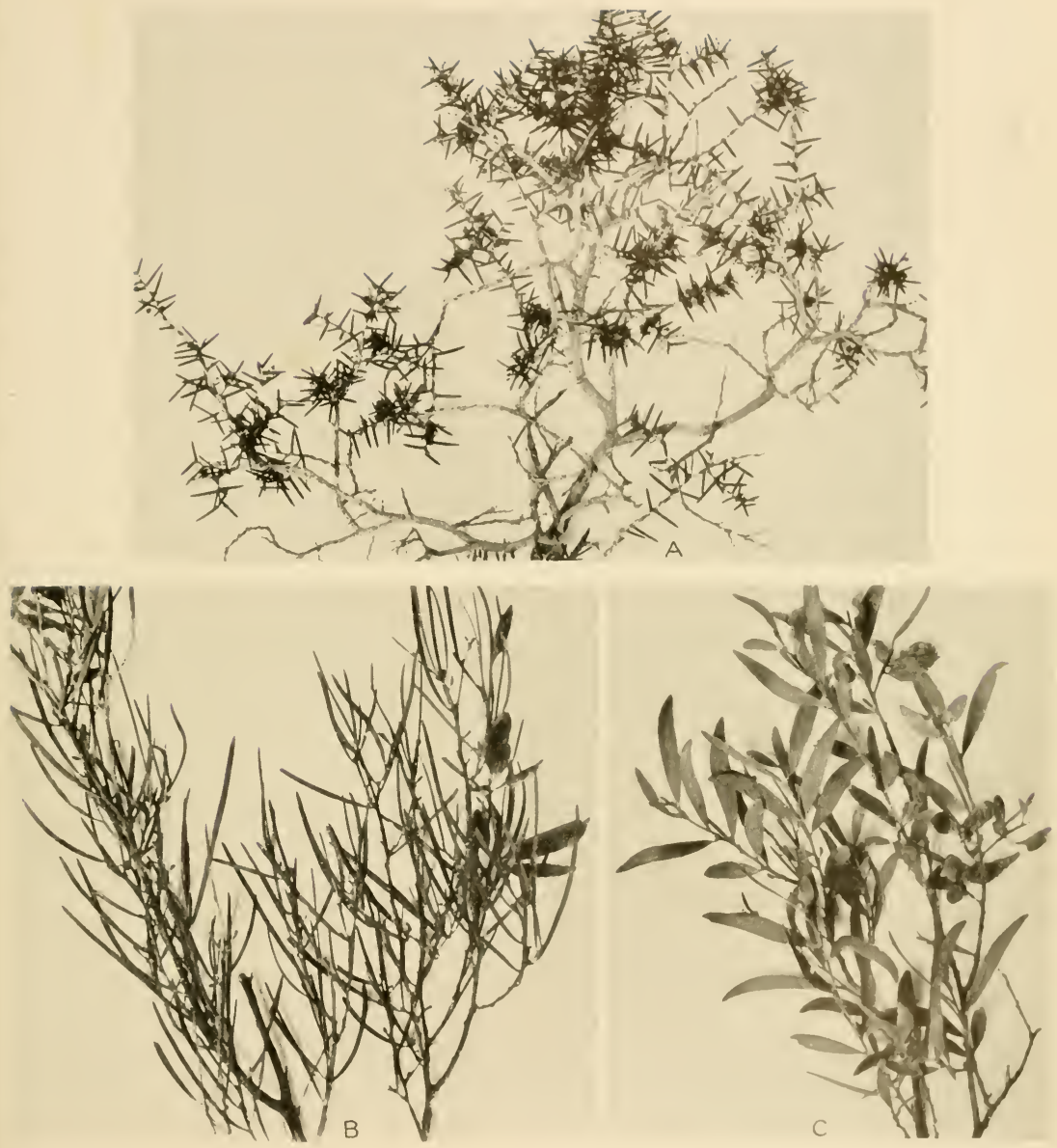

A. Detail of branch of Acacia colletioides, showing spine-like phyllodia. Ooldea.

B. Narrow "leaf" form of Acacia aneura, the mulga, at Ooldea. Young fruit is shown on one branch.

C. Broad "leaf" form of Acacia aneura, the mulga, at Ooldea. 


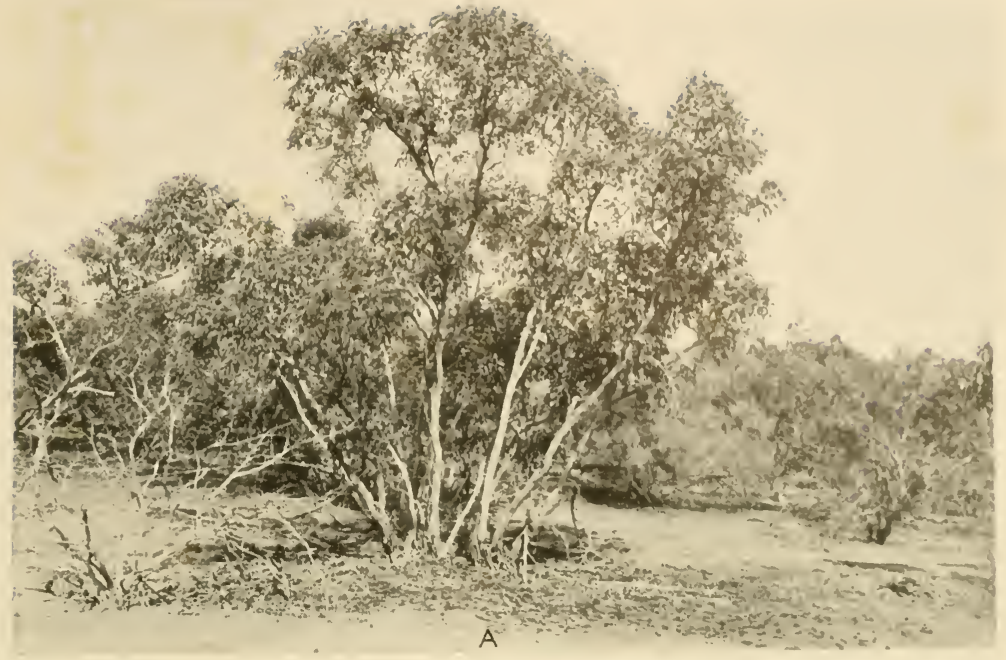

$$
\text { 然 }
$$

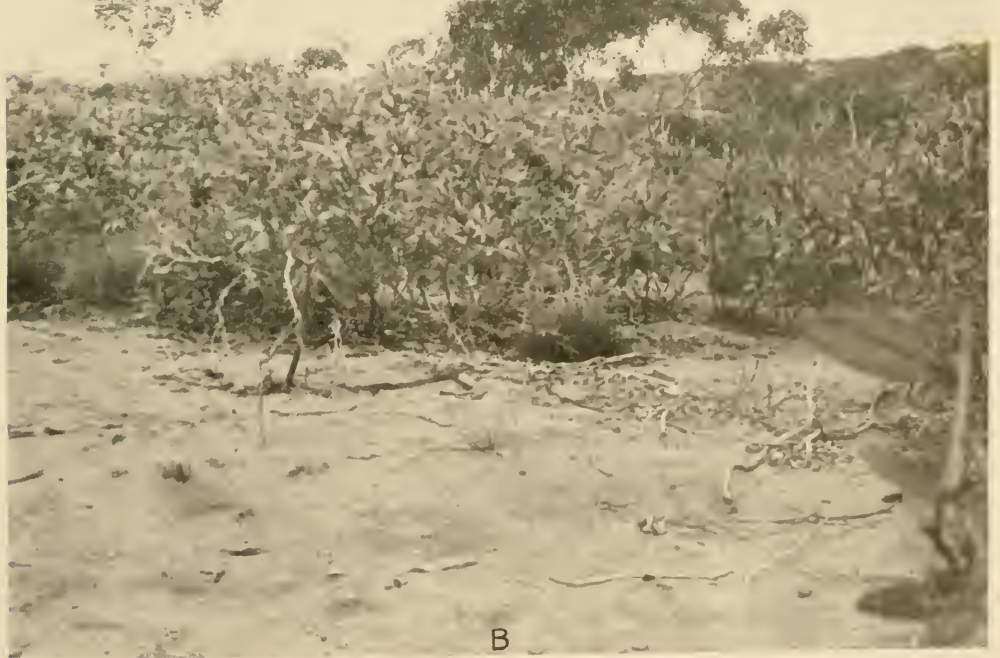

A. Eucalyptus pyriformis at Ooldea. Various speeies of Acacin and the mallee, Euculyptus incrassata var. dumosa, make up the surrounding woody vegctation. The floor ts are.
B. Eucalyptus leucoxylon var. macrocarpa, middle ground, and E. incrassata var. dumosa, on the hillside beyond, near Ooldea. 


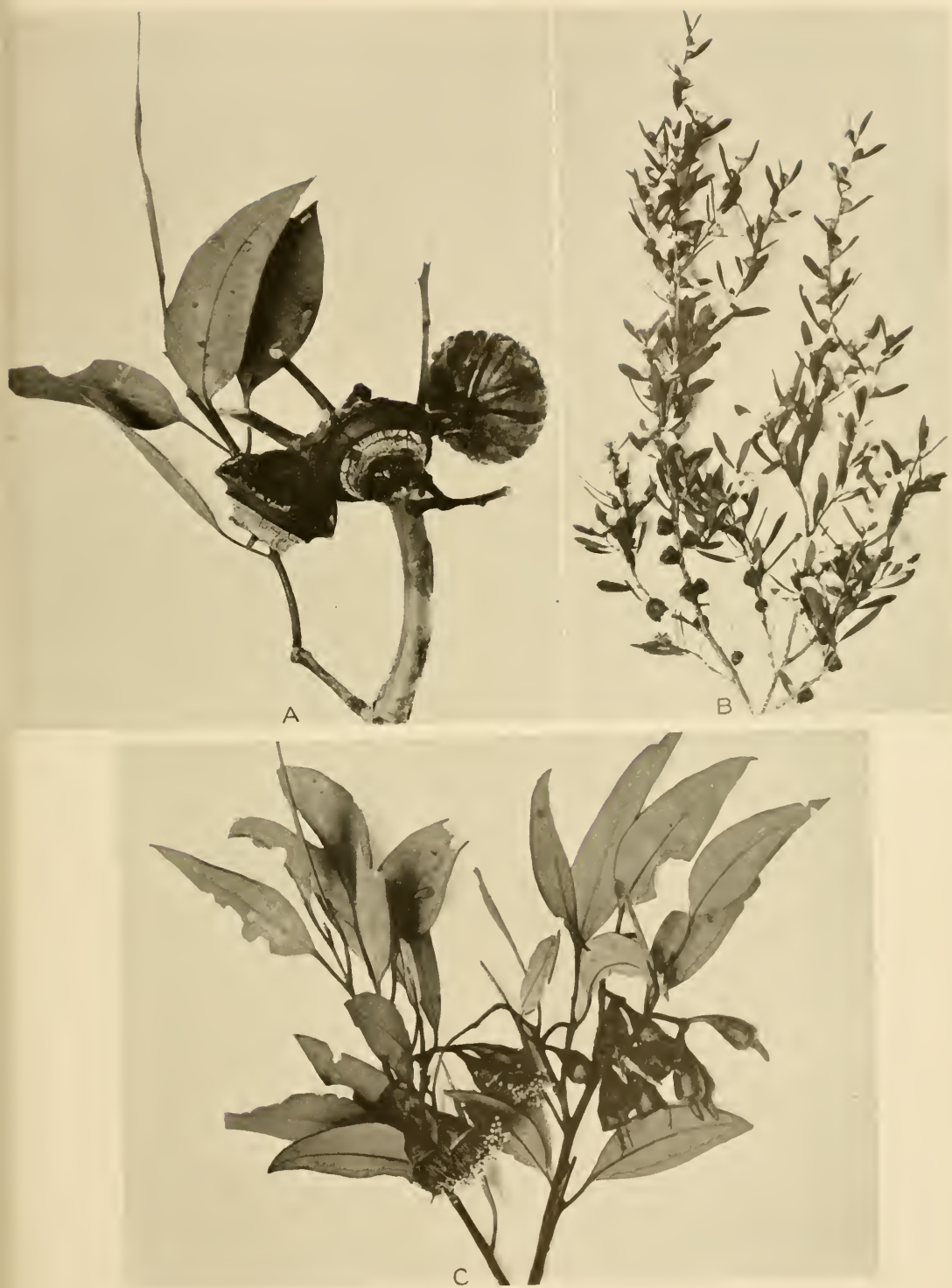

A. Fruits of Eucalyptus pyriformis from Ooldea. The fruits are about $5 \mathrm{~cm}$. in diameter.

B. Leptospermum levigatum var. minus, in flower, from the Ooldea Soak.

C. The shrubby Eucalyptus leucoxylon var. macrocarpa, in flower, from Station 40S, near Ooldea. 


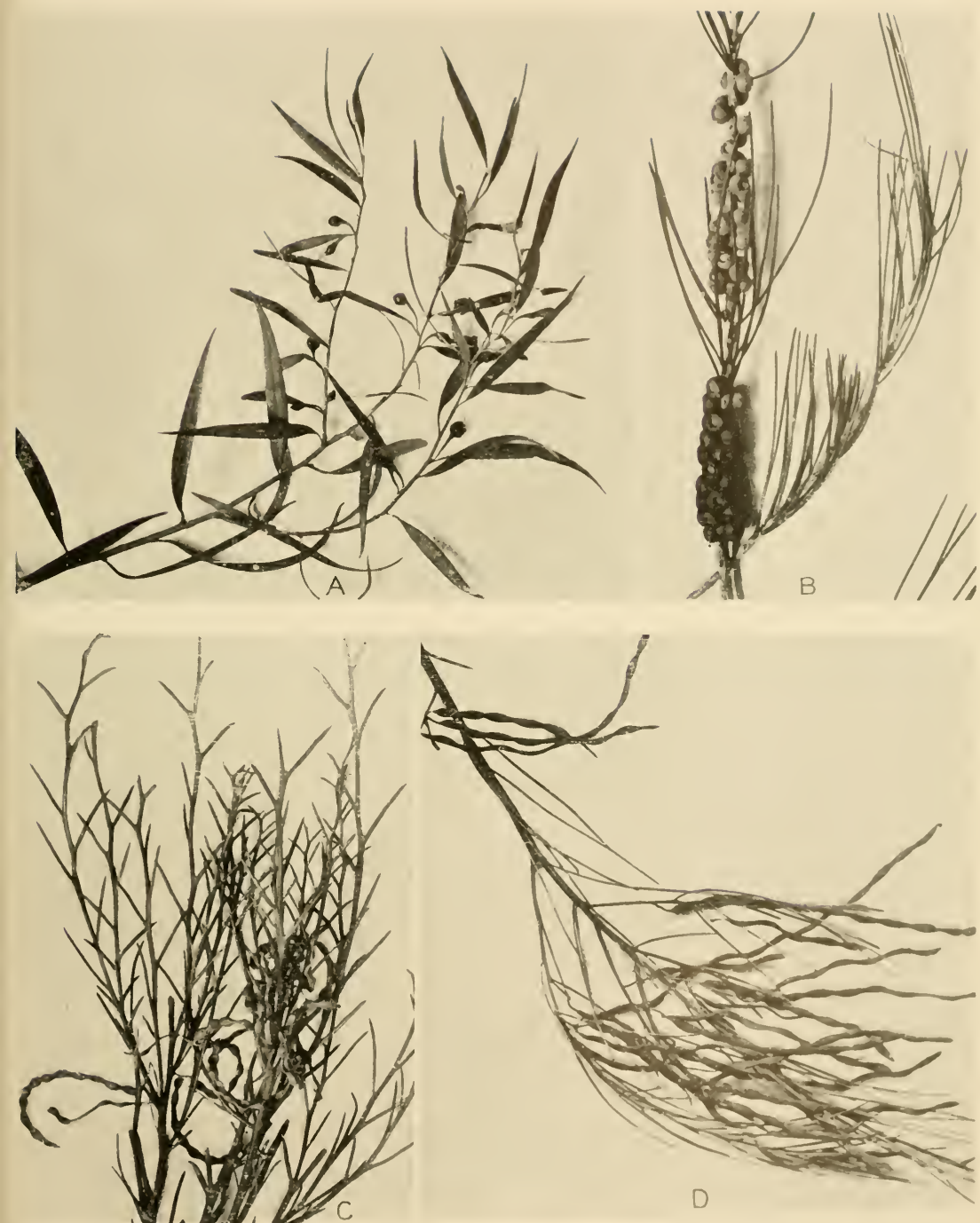

A. Pholitia santalina fıom mallee community on low ridge west of Quorn

B. Callistcmon teretifolius from ridge on Mount Arden road, Quorn.

C. Aphyllous Acacia continua from low hills on the Pichi Richi roakl, west of (Zuorn.

D. Tip of branch of Acacia calamifolia, in fruit, showing the linear phyllorlia. From open

Casuarina forest on the Melrose road, cast of Quorn. 


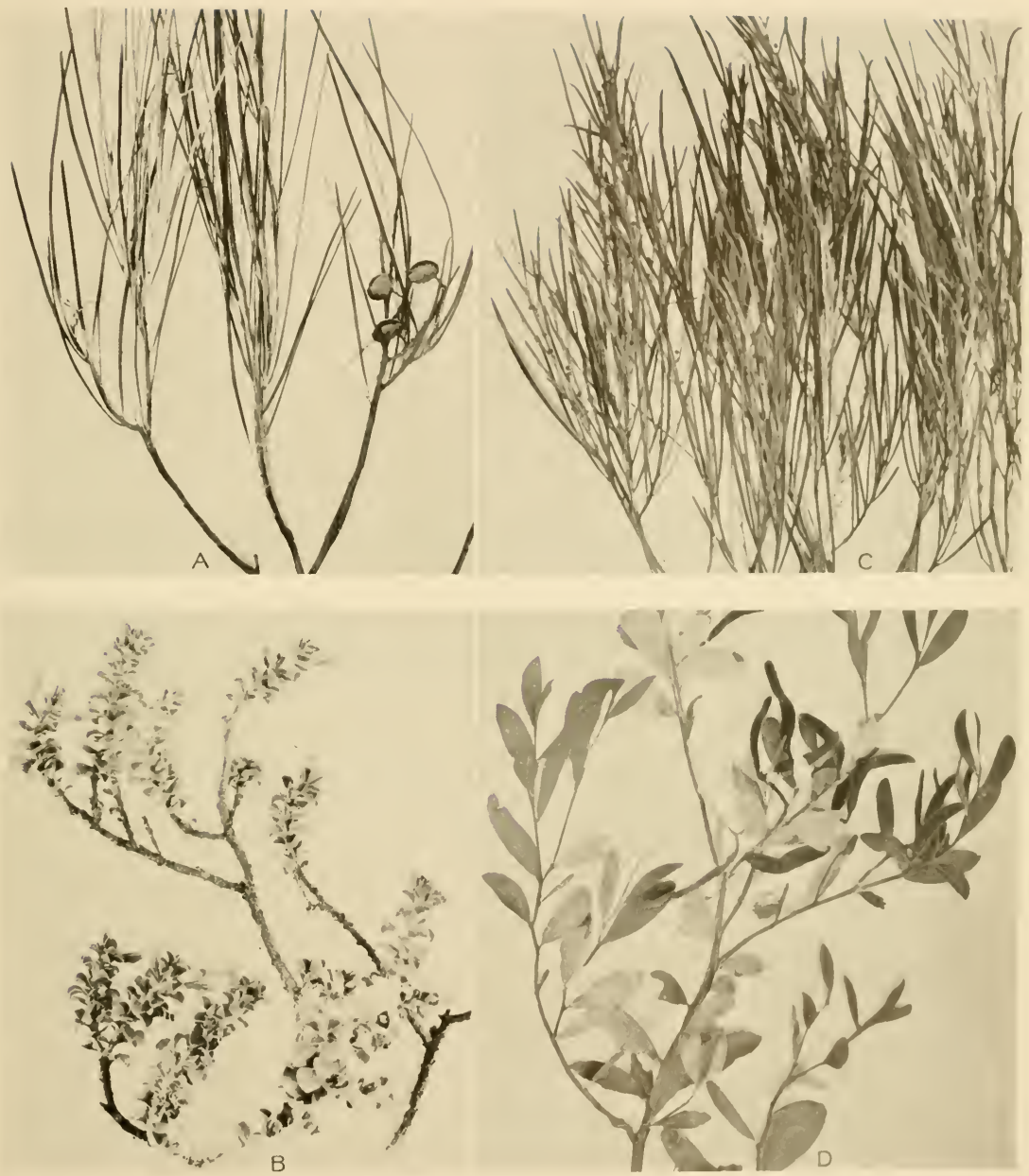

A. Gravillea stenobotrya shoot, showing leaves and fruits, from Station 40s, noar Ooldea.

B. Leaf habit of Eremophila rotundifolia, Tarcoola.

C. Tips of a branch of Acacia rigens, with phyllodia.

D. A fruiting branch of Acacia tarculiensis, showing characteristic plyyllodia. From type habitat, Tarcoola. 


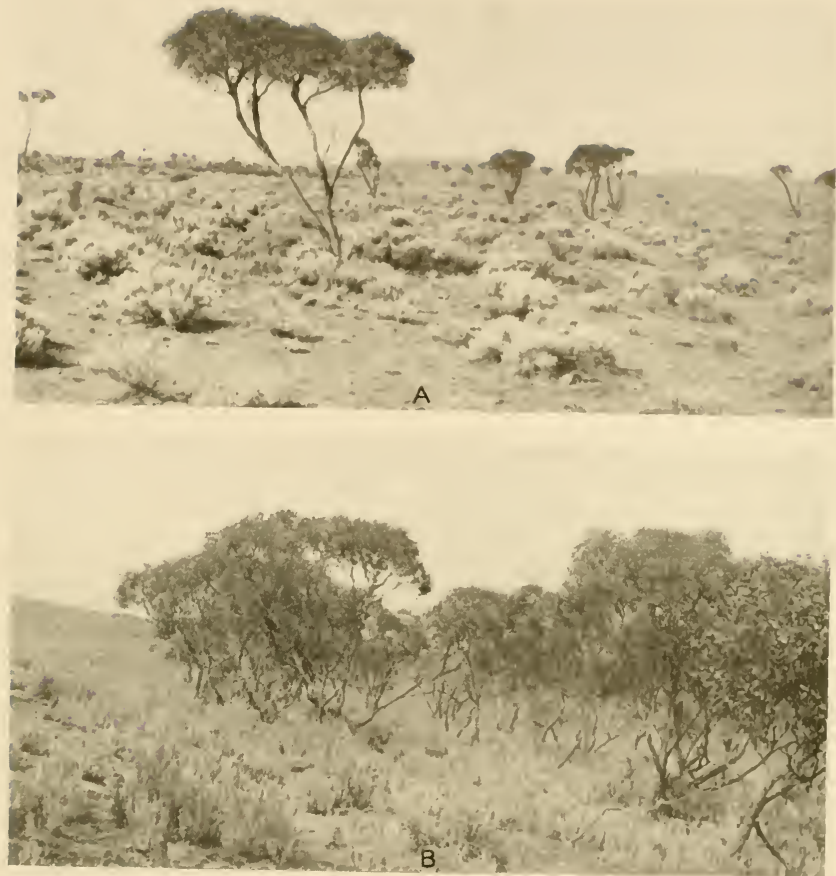

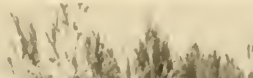
in a

F-

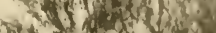

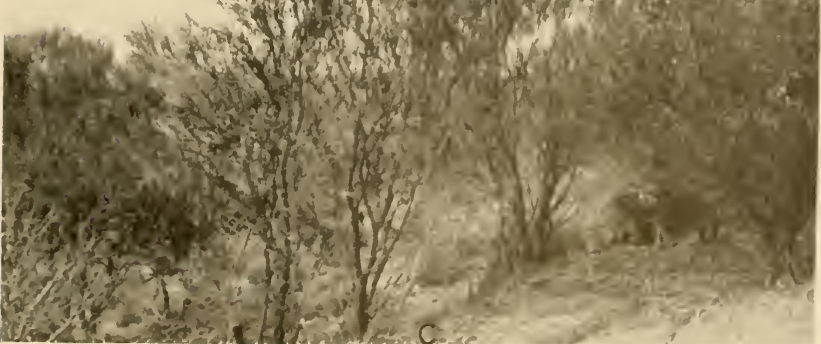

A. Acacia rigens, the "myall," with various halophytes, on pl:in north of Tareoola.

B. Thicket of mallee, Eucalyptus olensa, on sloping saltbush plain, foothills of the Flinders, east of Port Augusta, near sialtia.

C. "Beef wood," Gravillea stenobotrya, on the erest of sandhill by Station 408 , near Ooldea. 


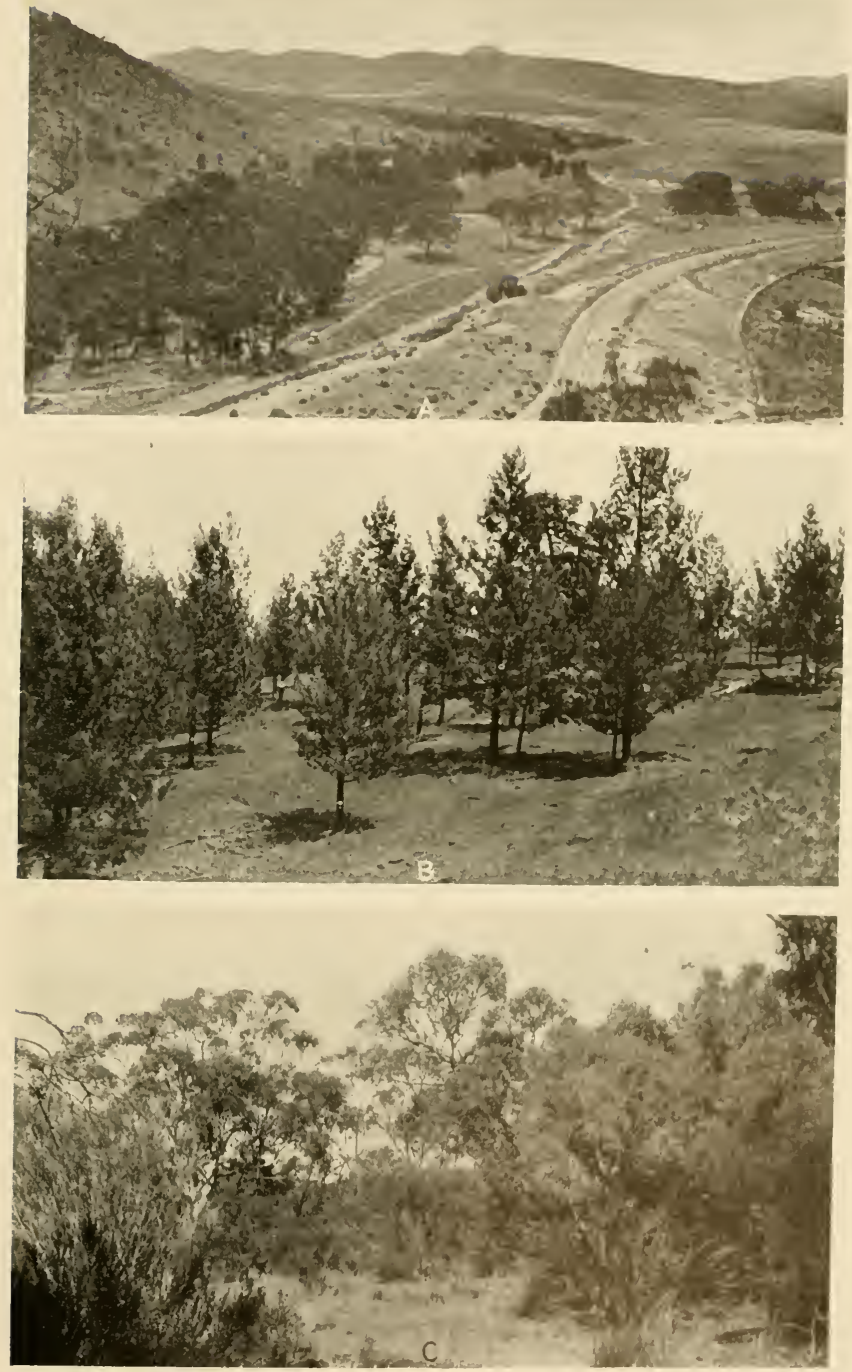

A. Forest of Eucalyptus rostrata on Saltia Creek, east of Port Augusta.

B. Pine community, Callitris robusta, at II arren's Gorge, near (Quorn.

C. View in mallee scrub, about 2 miles north of (Quorn. Euculyptus ortoratu and E. oleosa in background. Bunches of T'riodin irritaus in foreground. 


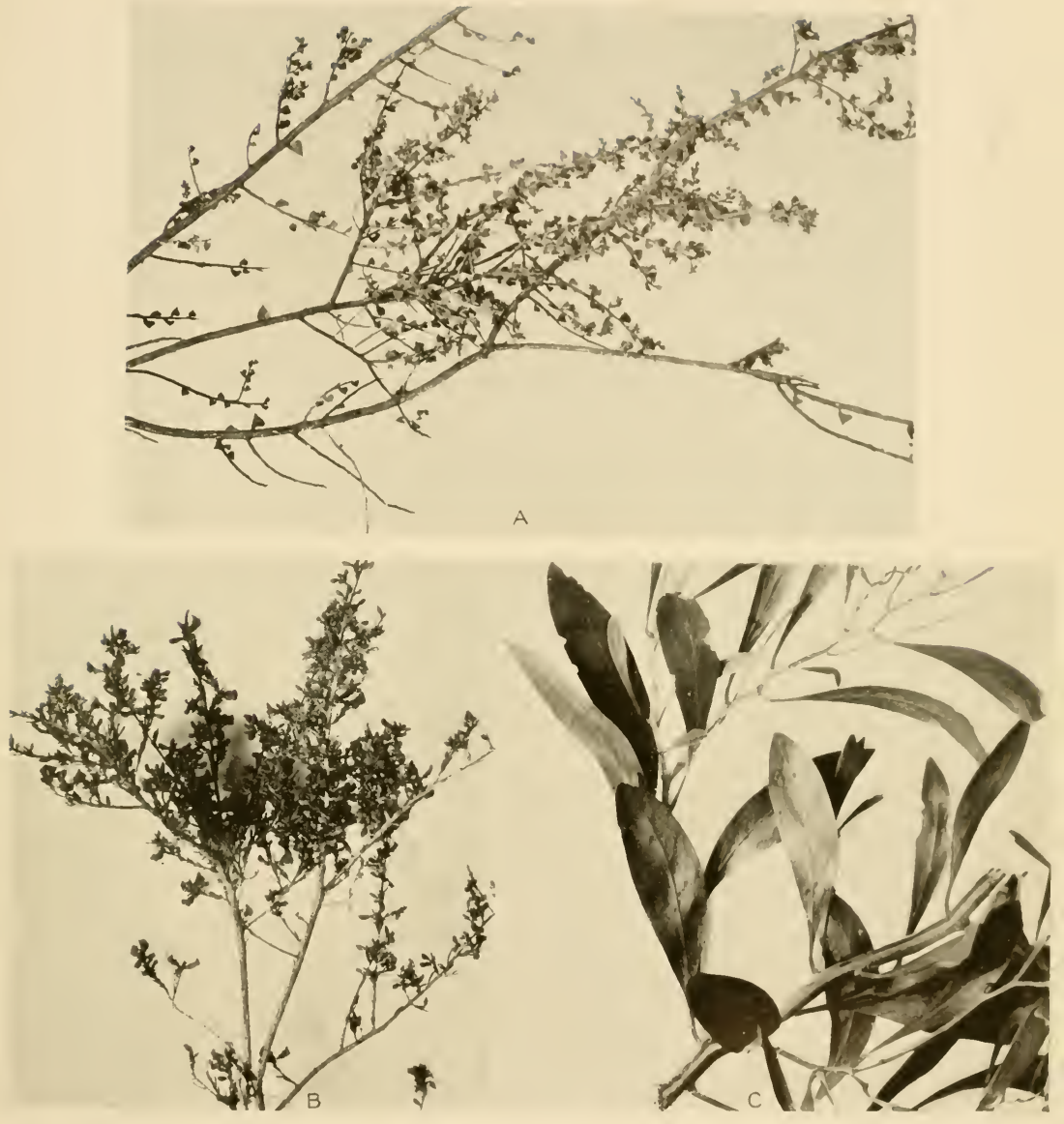

A. Branches of Acacia sublanata, showing small and rigid phyllodia. Quorn.

B. Eutaxia empetrifolia, showing the small flowers and linear short leaves. Quorn.

C. Branehes of Acacia pycnantha, the "golden wattle," showing the character of the large phyllodia. Quorn. 


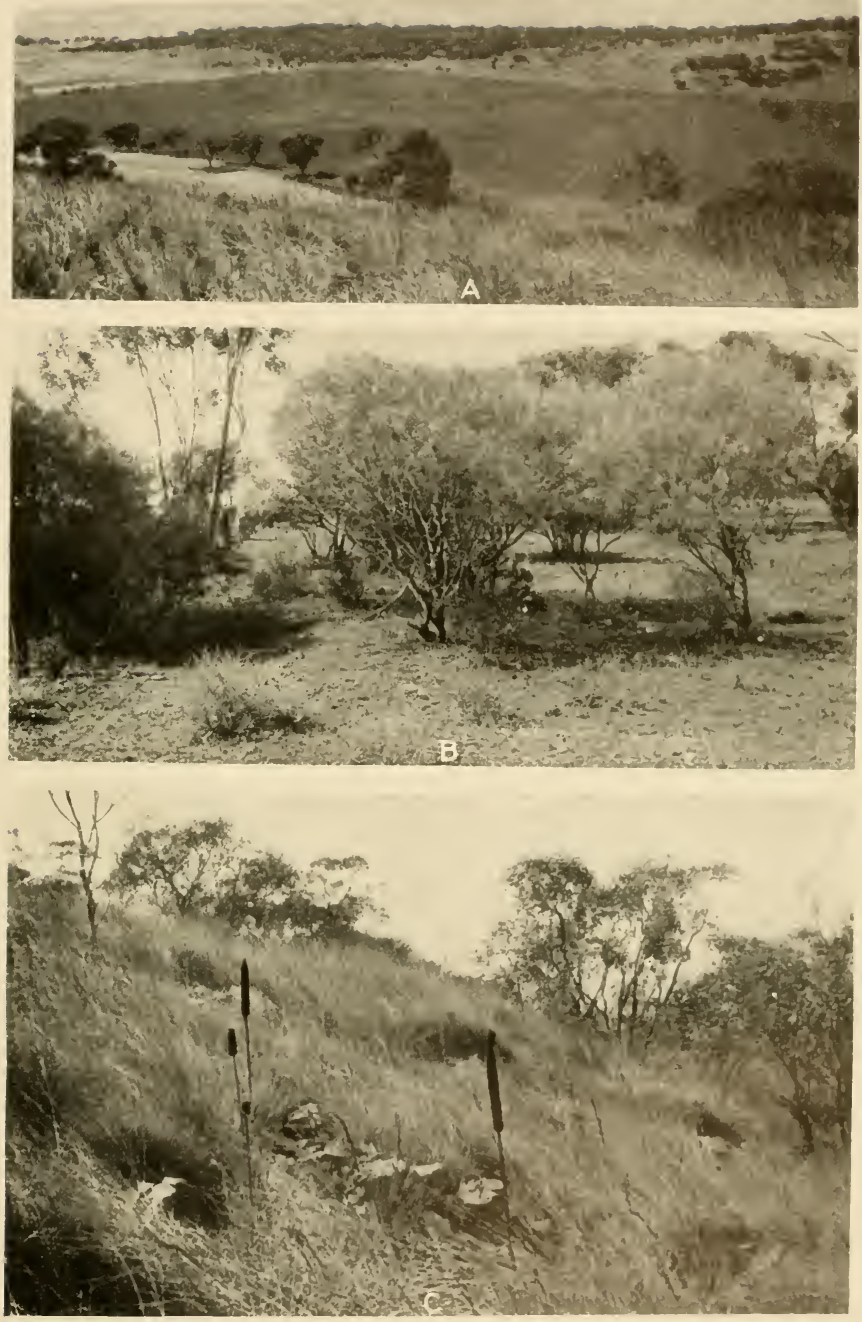

1. View about 2 miles west of Quorn, taken from a grassy ridge and looking upon a ridge which is eovered with mallee. In the intervening valley are it few speeimens of Eucalyptus leucoxylon var. pauperito.

B. Hakea leucoptera on the edge of the mallee serub, ahout 2 miles north of (2uorn. Small shoots which spring from superficial roots of the larger plants are in the foreground.

C. Western slope of ridge along Mount Arden road, (Quorn, with Triodia irrilans and Trichinium, dominant grasses. Dead fruiting stalks of Xanthorrhoa srmiplana show in the foreground; mallee, Eucalyptus sp., in the hackground. 


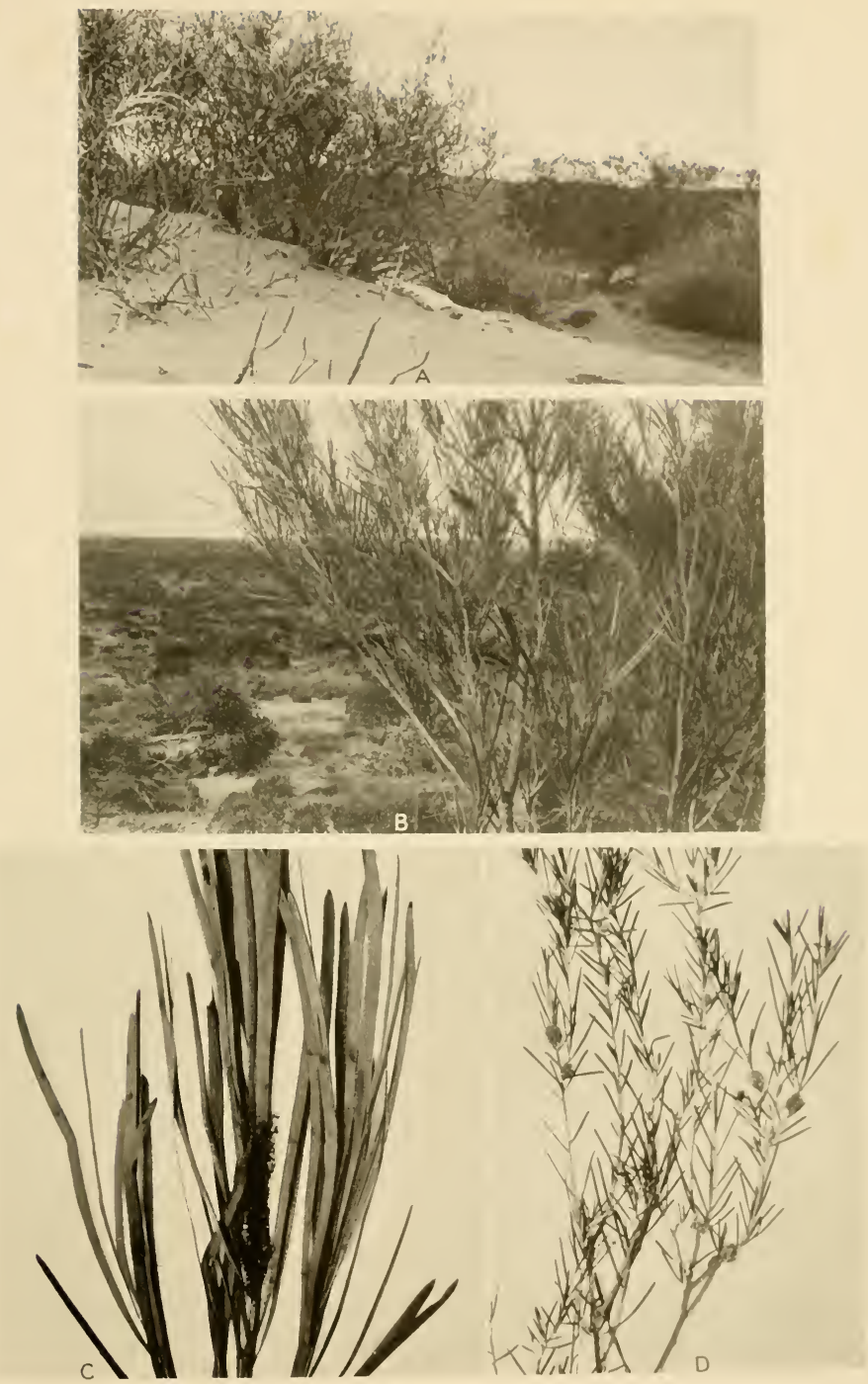

A. Bossirea walkeri on summit of a sandlhill by station $40 \varsigma$, near Ooldea.

A. Hakea multilincata on the crest of a sandhill by station $40 \mathrm{~s}$. near Ooldea, with Eucalyptus incrassata var. dumosa, a mallee, in the flats below. Bunches of spinifex, Triodia irritans, are to be seen between the mallee.

C. Braneh with withered flower-spike and leaves of Hakea mullilineala, from Station 408 , near Ooldea.

D. Melaleuca uncinata in fruit, from the sandhills by Station 408 , near Ooldea. 


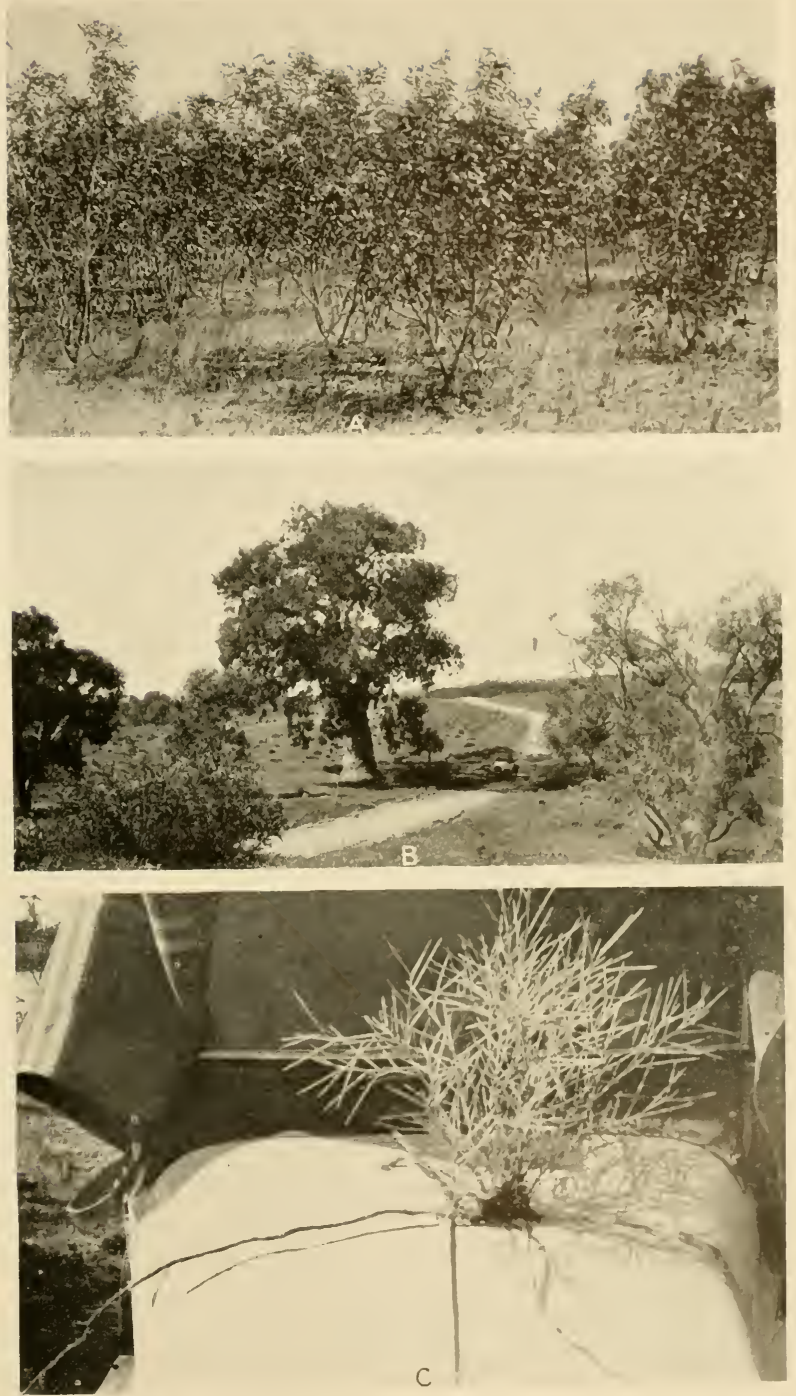

A. Community ef Acacia pycnanthe, the golden wattle, by a streamway on the Mlount Brown road, Quom.

B. Large specimen of Eucalyptus leucoxylor var. pauperita ly a wash on the Mount Arden road, Quorn. I comparison with the automobile will give an idea of its size. C. Vegetative reproduction in Hakea lcucoptcra. A young shoot, remover
from the soil, is shown taking its origin from a horizontal root. Quorn. 


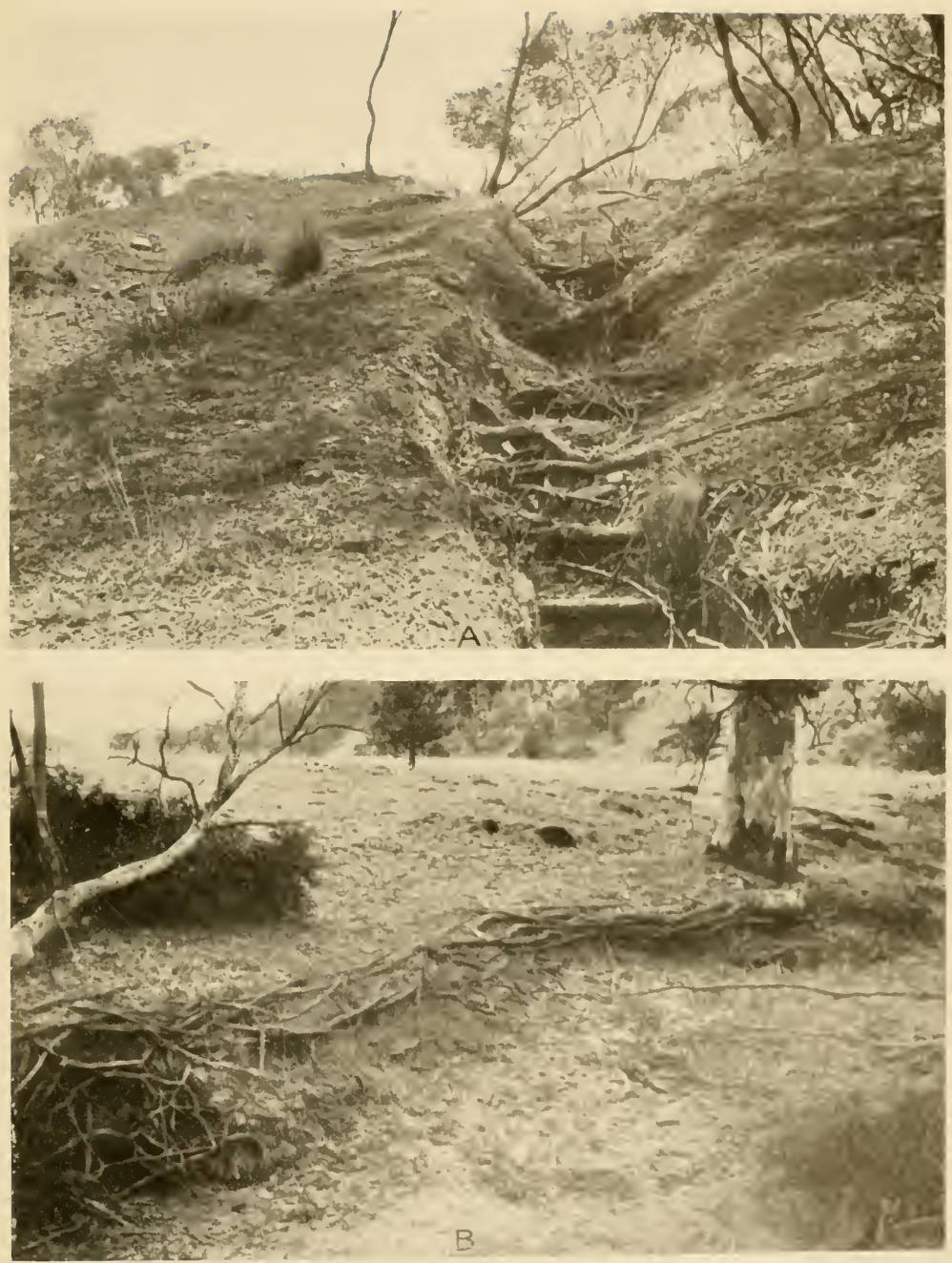

A. Exposure of roots of mallee, Eucalyptus sp., by a narrow wash, showing the abundance of superficial roots. Along the Mount Arden roarl, Quorn.

B. Root exposure of Eucalyptus leucoxylon var. pauperita by erosion of the hank of stream above Warren's Gorge. The roots were washed out for a distance expeeding 16 ineters. Quorn. 


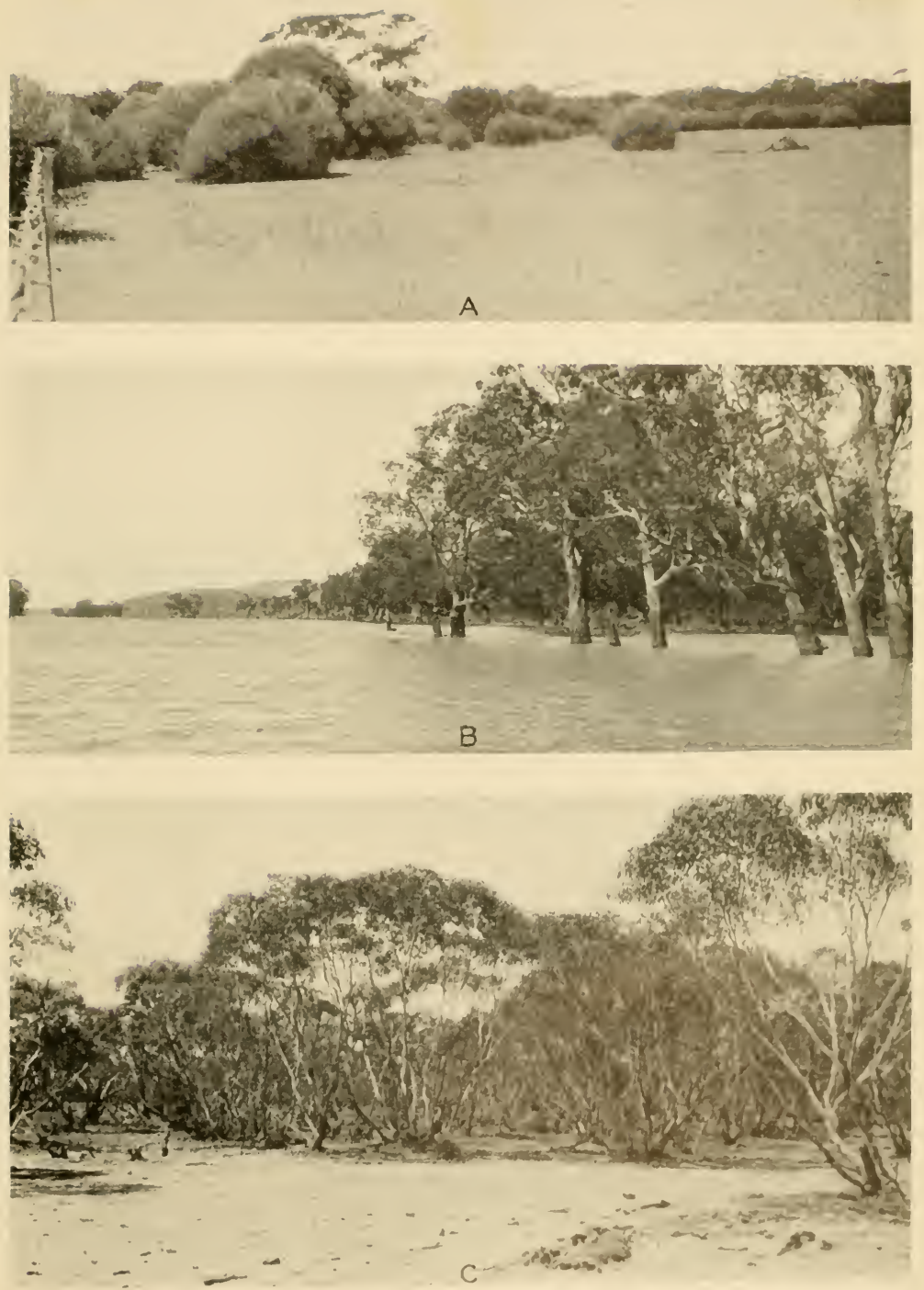

A. Scattered groups of Melalenca parriflora, in the mallee surub wear Bl.1nchtown.

B. Flood plain of the Murray River, showing open forest of Eucalyptus rostrata partly submergent, Blanchtown.

C. View in mallee, Eucalyptus sp., scrub on Murray flats near Blanchtown. 





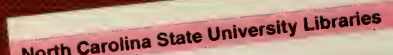

\section{North Carolin}

QK971 .S5 C3 3 MBITATS IN THE ARID PORTION

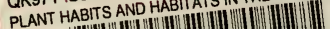

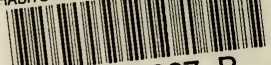

S02778367 P 